\title{
Improving Natural Uranium Utilization by Using Thorium in Low Moderation PWRs - A Preliminary Neutronic Scoping Study
}

Gilles Youinou Ignacio Somoza

October 2010

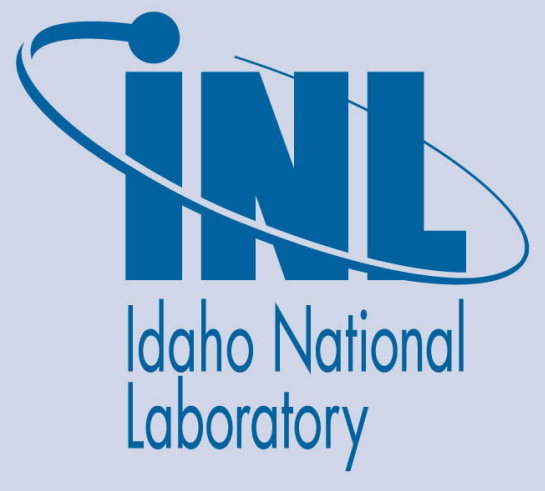

The INL is a U.S. Department of Energy National Laboratory operated by Battelle Energy Alliance 
INL/EXT-10-20155

FCRD-SYSA-2011-000002

\title{
Improving Natural Uranium Utilization by Using Thorium in Low Moderation PWRs -- A Preliminary Neutronic Scoping Study
}

\author{
Gilles Youinou \\ Ignacio Somoza
}

October 2010

\author{
Idaho National Laboratory \\ Fuel Cycle Research \& Development \\ Systems Analysis Campaign \\ Idaho Falls, Idaho 83415 \\ htto://www.inl.aov
}

Prepared for the

U.S. Department of Energy

Office of Nuclear Energy

Under DOE Idaho Operations Office

Contract DE-AC07-05ID14517 


\section{DISCLAIMER}

This information was prepared as an account of work sponsored by an agency of the U.S. Government. Neither the U.S. Government nor any agency thereof, nor any of their employees, makes any warranty, expressed or implied, or assumes any legal liability or responsibility for the accuracy, completeness, or usefulness, of any information, apparatus, product, or process disclosed, or represents that its use would not infringe privately owned rights. References herein to any specific commercial product, process, or service by trade name, trade mark, manufacturer, or otherwise, does not necessarily constitute or imply its endorsement, recommendation, or favoring by the U.S. Government or any agency thereof. The views and opinions of authors expressed herein do not necessarily state or reflect those of the U.S. Government or any agency thereof. 


\section{SUMMARY}

The Th-U fuel cycle is not quite self-sustainable when used in water-cooled reactors and with fuel burnups higher than a few thousand MWd/t characteristic of CANDU reactors operating with a continuous refueling. For the other industrially mature water-cooled reactors (i.e. PWRs and BWRs) it is economically necessary that the fuel has enough reactivity to reach fuel burnups of at least $40,000 \mathrm{MWd} / \mathrm{t}$. In this particular case, an additional input of fissile material is necessary to complement the bred fissile U-233. This additional fissile material could be included in the form of Highly Enriched Uranium (HEU) at the fabrication of the Th-U fuel.

The objective of this preliminary neutronic scoping study is to determine (1) how much HEU and, consequently, how much natural uranium is necessary in such Th-U fuel cycle with $U$ recycling and (2) how much TRansUranics (TRU=Pu, Np, $\mathrm{Am}$ and $\mathrm{Cm}$ ) are produced. These numbers are then compared with those of a standard $\mathrm{UO}_{2} \mathrm{PWR}$.

The thorium reactors considered have a homogeneous hexagonal lattice made up of the same (Th-U) $\mathrm{O}_{2}$ pins. At this point, we are not considering the use of blankets inside or outside the core. The low moderation has been obtained by varying the lattice pitch and by using heavy water instead of light water as the coolant. Water-to-fuel volume ratios of 2 (value corresponding to actual operating PWRs), 1 and 0.6 have been considered. For most cases, an average burnup at discharge of 45,000 MWd/t has been considered.

This preliminary neutronic scoping study shows the following trends (see the figures on the next page):

$>$ If the coolant is light water, the natural $U$ utilization can be increased by a factor of between 1.5 and 2 compared to that of a standard $\mathrm{UO}_{2}$ reactor (see Figures S.1 \& S.2a). The influence of the water-to-fuel volume ratio is not very large and, as far as natural $U$ utilization goes, there is not a strong incentive to use a tight lattice when light water is the coolant. The natural $U$ utilization is not very sensitive to the reprocessing losses.

$>$ If the coolant is heavy water, the natural $U$ utilization can be increased by a factor of between 15 and 20 compared to that of a standard $\mathrm{UO}_{2}$ reactor (see Figures S.1 \& S.2b) if the reprocessing losses are small $(0.1 \%)$. With $2 \%$ losses at reprocessing, the natural $U$ utilization decreases by about a factor of 2.5. There is here a strong incentive to use a tight lattice when heavy water is the coolant since the natural $U$ utilization increases rapidly as the water-to-fuel volume ratio decreases (factor of 10 between the water-to-fuel volume ratio of 2 and that of 0.6 ).

$>$ The amount of TRU produced by these Thorium fuels is about a factor of 2 to 4 lower than that produced by a standard $\mathrm{UO}_{2}$ fuel. Furthermore, whereas the TRU contained in standard $\mathrm{UO}_{2}$ spent fuel is essentially made up of $\mathrm{Pu}(85 \%-90 \%)$, the TRU produced by these Thorium fuels is for the most part made up of Np237 (50\%-60\%). The heat load of the TRU that needs to be disposed of is substantially lower than that of standard $\mathrm{UO}_{2}$ spent fuel.

$>$ Increasing the fuel burnup of the Thorium fuel from 45,000 MWd/t to $60,000 \mathrm{MWd} / \mathrm{t}$ (Figure S.3) decreases the natural $U$ utilization by about a factor of 2, but it is still about a factor of 10 higher than that of a standard $\mathrm{UO}_{2}$ reactor (with small reprocessing losses). The sensitivity of the natural $\mathrm{U}$ needs with regard to the reprocessing losses is higher for the $45,000 \mathrm{MWd} / \mathrm{t}$ cases than for the $60,000 \mathrm{MWd} / \mathrm{t}$ cases. As a result, the natural $\mathrm{U}$ needs obtained for these two burnups are the same if the reprocessing losses are as high as $4 \%$.

> The tight-pitch heavy-water-cooled reactors are very close to being self-sustained and the use of Thorium blankets outside or inside the core may produce enough $U$ to reach self-sustainability or at least compensate for the reprocessing losses. This aspect should be treated in more details in the future. 


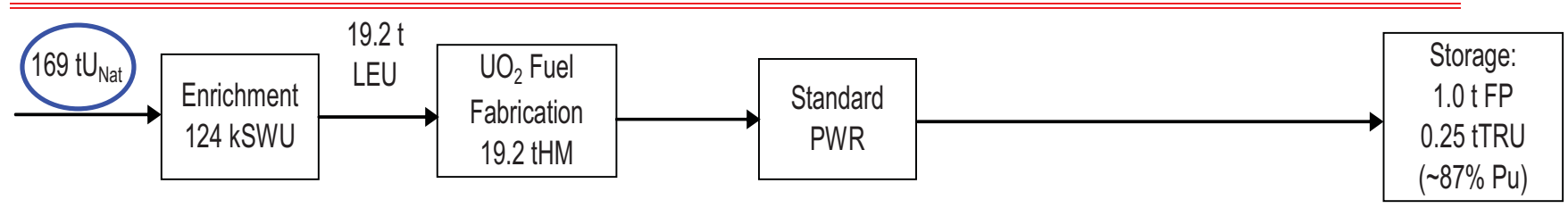

Figure S.1. Static equilibrium annual mass flows for the reference $1 \mathrm{GWe} \cup \mathrm{O}_{2} \mathrm{PWR}$.

Burnup $=\underline{51,000} \mathrm{MWd} / \mathrm{t}_{\text {HM }}$. Energy $=8 \mathrm{TWhe}$.

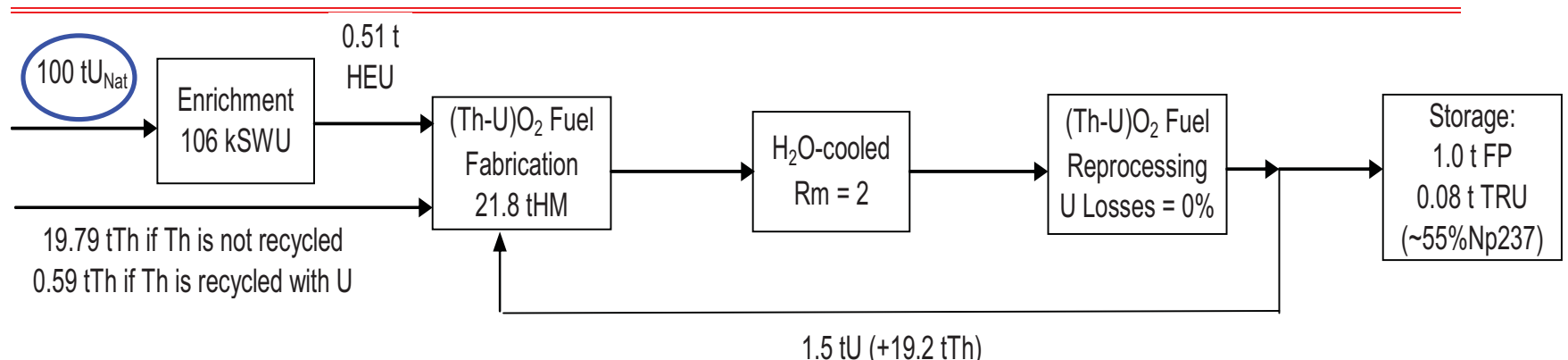

(a)

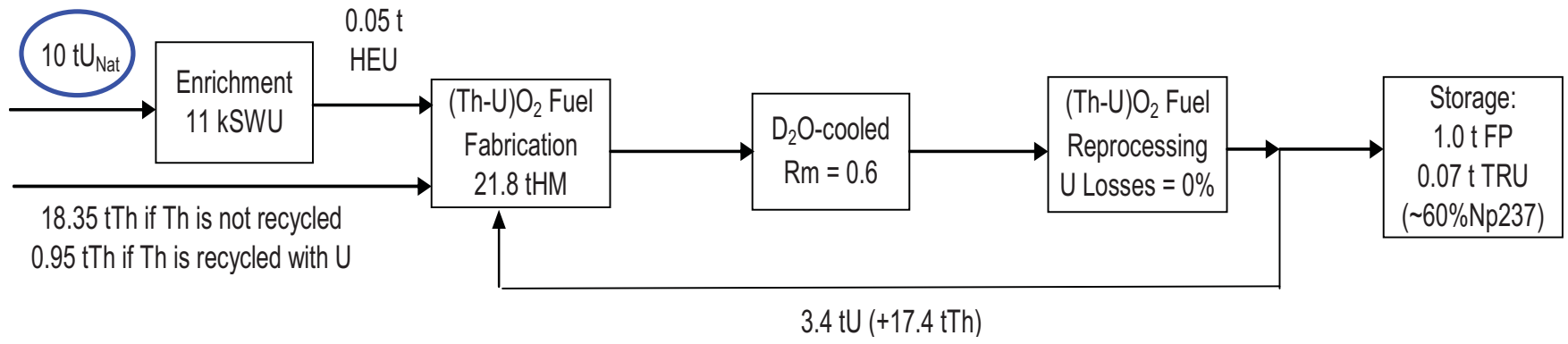

(b)

Figure S.2. Static equilibrium annual mass flows for a $1 \mathrm{GWe}$ light-water-cooled Thorium reactor with a water-to-fuel volume ratio of 2 (a), and for a $1 \mathrm{GWe}$ heavy-water-cooled Thorium reactor with a water-tofuel volume ratio of 0.6 (b). Burnup $=\underline{45,000} \mathrm{MWd} / \mathrm{t}_{\mathrm{HM}}$. Energy $=8 \mathrm{TWhe}$.

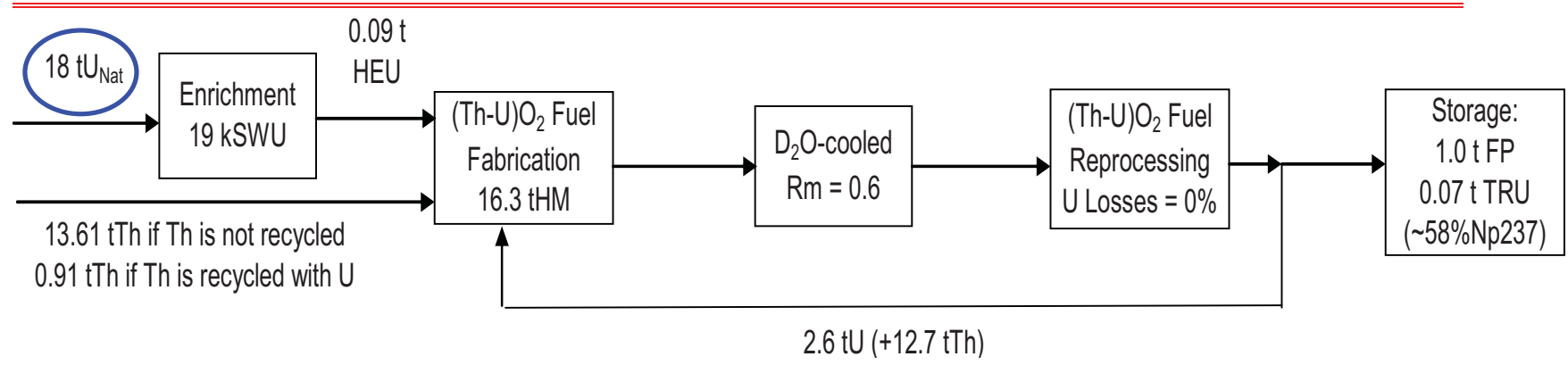

Figure S.3. Static equilibrium annual mass flows for a $1 \mathrm{GWe}$ heavy-water-cooled Thorium reactor with water-to-fuel volume ratio of 0.6. Burnup $=\underline{60,000} \mathrm{MWd} / \mathrm{t}_{\text {HM }}$. Energy $=8 \mathrm{TWhe}$. 


\section{CONTENTS}

Summary

0. Acknowledgement

1. Introduction

2. Methodology and Hypotheses.

3. Heavy Water, Light Water and Neutron Spectrum - General Considerations

4. The Reference $\mathrm{UO}_{2}$ reactor

5. The light-water-cooled $(\mathrm{Th}-\mathrm{U}) \mathrm{O}_{2}$ reactors

6. The heavy-water-cooled $(\mathrm{Th}-\mathrm{U}) \mathrm{O}_{2}$ reactors

7. The heavy-water-cooled (Th-Pu-U) $\mathrm{O}_{2}$ reactors

8. Taking the reprocessing losses into account.

9. The heavy-water-cooled $(\mathrm{U}-\mathrm{Pu}) \mathrm{O}_{2}$ reactors

10. The self-sustained Th-U CANDU reactor. No free lunch

11. Conclusions

12. References

Appendix A. The U232 issue

Appendix B. Impact of the HEU isotopic composition.

Appendix C. Details of TRU that needs to be disposed of

Appendix D. Heat load related to the TRU that needs to be disposed of $\underline{60}$ Appendix E. Preliminary estimation of the amount of $\mathrm{U}$ produced in $\mathrm{ThO}_{2}$ rods 



\section{SYSTEMS ANALYSIS CAMPAIGN}

\section{Acknowledgement}

The help of Bill Skerjanc from the INL Reactor Physics Department who showed us how to use the lattice physics code HELIOS is gratefully acknowledged.

\section{Introduction}

From the very beginning of the nuclear energy development, thorium has always been considered as a possible substitute for uranium because, among other things, it is 3 to 4 times more abundant than uranium. The four IAEA reports published between 2000 and 2005 give a broad overview of the work done on the subject [1.1-1.4].

The Th-U fuel cycle is not quite self-sustainable when used in water-cooled reactors and with fuel burnups higher than a few thousand $\mathrm{MWd} / \mathrm{t}$ characteristic of CANDU reactors operating with a continuous refueling. For the other industrially mature water-cooled reactors (i.e. PWRs and BWRs) it is economically necessary that the fuel has enough reactivity to reach fuel burnups of at least $40,000 \mathrm{MWd} / \mathrm{t}$. In this particular case, an additional input of fissile material is necessary to complement the bred fissile U233. This additional fissile material could be included in the form of Highly Enriched Uranium (HEU) at the fabrication of the Th-U fuel (Figure 1.1).

HEU would be down-blended to Th-U in a way similar to the down-blending of HEU to Low Enriched Uranium (LEU) that has been going on in the US since 1993 for use in civilian reactor in the framework of the US-Russian Federation agreement [1.5] (The HEU Agreement, signed in 1993, provides for the purchase over a 20-year period (1994-2013) of 500 tons of weapons-origin HEU from the Russian Federation)

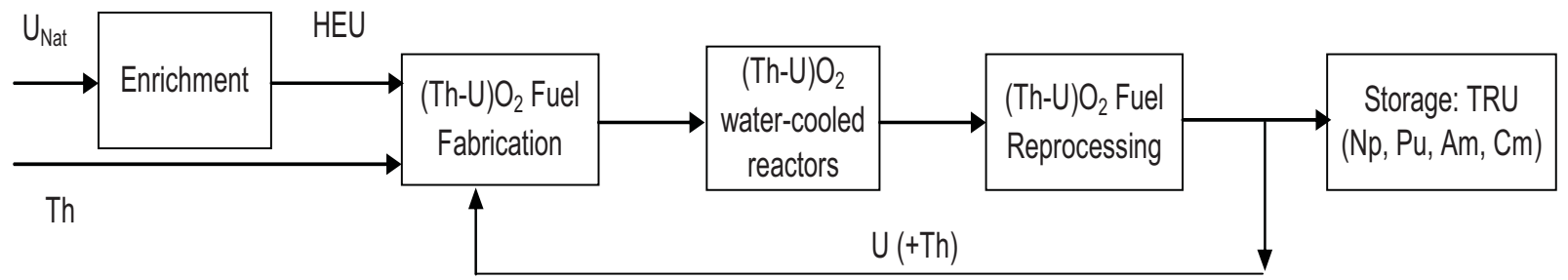

Figure 1.1. Th-U fuel cycle with HEU topping. 
The objective of this preliminary neutronic scoping study is to determine (1) how much HEU and, consequently, how much natural uranium is necessary in such a Th-U fuel cycle with $U$ recycling and (2) how much TRansUranics ( $T R U=\mathrm{Pu}, \mathrm{Np}, \mathrm{Am}$ and $\mathrm{Cm}$ ) are produced. These numbers are then compared with those of a standard $\mathrm{UO}_{2} \mathrm{PWR}$. The Th-based fuels with $U$ recycling have also been compared with U-Pu fuels with Pu recycling.

The thorium reactors considered have a homogeneous hexagonal lattice made up of the same (Th-U) $\mathrm{O}_{2}$ pins, i.e. we are not considering any seed-blanket type of assemblies (the kind of assemblies used in Shippingport during the Light Water Breeder Program for example [1.6]) which are potentially more efficient in breeding U-233 but which are potentially more complicated to implement as well. Furthermore, at this point, the use of blankets inside or outside the core has not been considered either. The lattice pitch has been varied to estimate the effect of the water-to-fuel volume ratio, and light water as well as heavy water have been considered. Burnups of $45,000 \mathrm{MWd} / \mathrm{t}$ and $60,000 \mathrm{MWd} / \mathrm{t}$ have also been investigated to estimate the impact on the HEU needs.

\section{Methodology and Hypotheses}

Hexagonal pin cell calculations were carried out (Figure 2.1) with the lattice physics code HELIOS-2.0 [2.1] together with its 177-group ENDF/B-VII.O [2.2] based nuclear-data library. HELIOS-2.0 is applicable to BWR and PWR, as well as Magnox, RBMK, CANDU, AGR and VVER fuel assemblies. Multi-assembly geometries, up to full reactor cores for research reactors can be calculated. HELIOS-2.0 has been validated for these applications.

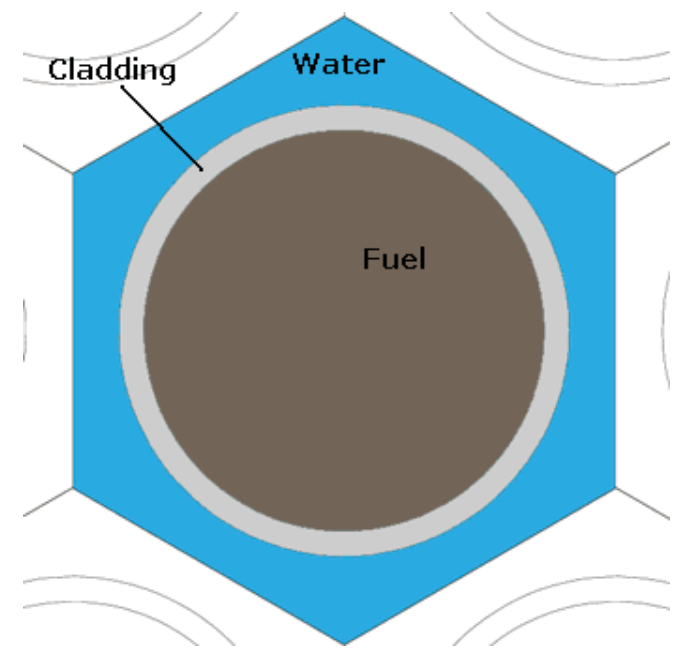

Figure 2.1. Hexagonal pin lattice modeled with HELIOS-2. Fuel rod radius $=9.5 \mathrm{~mm}$. 
The calculations carried out simulate the fuel cycle represented on the Figure 1.1. After an irradiation cycle, the $(\mathrm{Th}-\mathrm{U}) \mathrm{O}_{2}$ fuel is recycled and the uranium is used to fabricate the $(\mathrm{Th}-\mathrm{U}) \mathrm{O}_{2}$ fuel for the next cycle. As mentioned in Chapter 1 , in order for the fuel to have enough reactivity to reach a given target burnup, an additional input of HEU, $m_{H E U}^{n+1}$, is necessary at the $(n+1)^{\text {th }}$ fabrication to complement the uranium recuperated from the $n^{\text {th }}$ irradiation, $m_{U-r e p}^{n} \times\left(1-L_{U}\right)$ where $L_{U}$ represents the uranium losses at reprocessing. Two values of uranium losses at reprocessing, $L_{U}$, have been considered: $0 \%$ and $2 \%$.

The necessary fissile content at each cycle is determined with a standard methodology: the $k_{\infty}$ at the average end-of-cycle burnup $\left(\bar{B}_{E O C}\right)$, without soluble boron, is equal to that of a reference $4 \% \cup_{2}$ pin calculated using the same methodology. For our particular case, the value of $k_{\infty}$ at the average end-ofcycle burnup $\left(\bar{B}_{E O C}\right)$ is equal to 1.0468 . In other words, the mass of HEU is adjusted in order to maintain a constant average fuel burnup at discharge whatever the isotopic composition of the uranium is. This can be expressed as follows:

$$
m_{U-f a b}^{n+1}=m_{U-r e p}^{n} \times\left(1-L_{U}\right)+m_{H E U}^{n+1} \quad \rightarrow \quad k_{\infty}^{n+1}\left(\bar{B}_{E O C}\right)=k_{\infty}^{n}\left(\bar{B}_{E O C}\right)=k_{\infty}\left(\bar{B}_{E O C}\right)=1.0468
$$

To estimate the sensitivity of $m_{H E U}^{n+1}$ with regard to the value considered for $k_{\infty}\left(\bar{B}_{E O C}\right)$ a few calculations were run considering $k_{\infty}\left(\bar{B}_{E O C}\right)=1.056$ instead of $k_{\infty}\left(\bar{B}_{E O C}\right)=1.0468$.

Two average fuel burnup at discharge have been considered for this study: $\underline{45,000 \mathrm{MWd} / \mathrm{t}}(3 \times 15,000$ $\mathrm{MWd} / \mathrm{t})$ and $\underline{60,000 \mathrm{MWd} / \mathrm{t}}(4 \times 15,000 \mathrm{MWd} / \mathrm{t})$ hence the average end-of-cycle burnup, $\bar{B}_{E O C}$, is equal to, respectively, 30,000 $\mathrm{MWd} / \mathrm{t}$ and $37,500 \mathrm{MWd} / \mathrm{t}$.

Once $m_{H E U}$ has been determined, the corresponding mass of natural uranium, $m_{U-n a t}$, as well as the SWU (Separating Work Units) necessary are calculated with the following classic expressions [2.3]:

$$
\begin{gathered}
m_{U-n a t}=\frac{e^{H E U}-e^{d e p l}}{0.711-e^{\text {depl }}} \times m_{H E U}, \\
S W U=m_{H E U} \times\left(2 e^{H E U}-1\right) \times \ln \left(\frac{e^{H E U}}{1-e^{H E U}}\right)+\left(m_{U-n a t}-m_{H E U}\right) \times\left(2 e^{d e p l}-1\right) \times \ln \left(\frac{e^{d e p l}}{1-e^{d e p l}}\right) \\
-m_{U-n a t} \times(2 \times 0.711 \%-1) \times \ln \left(\frac{0.711 \%}{1-0.711 \%}\right)
\end{gathered}
$$


where $e^{\text {HEU }}$ is the U235 enrichment of the HEU and $e^{\text {depl }}$ is the percentage of U235 left over in the depleted Uranium (a value of $0.25 \%$ was considered is this study). Unless otherwise stated, the HEU is considered to be made up of $\underline{90 \% \mathrm{U} 235}$ and $10 \% \mathrm{U} 238$, however, to assess the impact of the isotopic composition of the HEU, a few calculations have been run using a HEU' made up of $50 \%$ U235 and $50 \%$ U238. The mass of natural $U$ and SWU necessary to produce $1 \mathrm{~kg}$ of HEU depending on its enrichment are presented in $\underline{\text { Table } 2.1}$ below.

Table 2.1. Mass of natural $U$ and SWU necessary to produce $1 \mathrm{~kg}$ of HEU depending on its enrichment.

\begin{tabular}{|c|c|c|}
\hline$e^{\text {HEU }}$ & $90 \%$ & $50 \%$ \\
\hline$e^{d e p l}$ & $0.25 \%$ & $0.25 \%$ \\
\hline$m_{U-\text { nat }}(\mathrm{kg})$ & 195 & 108 \\
\hline$S W U$ & 208 & 112 \\
\hline
\end{tabular}

The fuel and zircaloy cladding radius are those of standard fuel rods used in PWRs, i.e. $0.418 \mathrm{~cm}$ and $0.475 \mathrm{~cm}$.

Light water and heavy water have been successively considered as coolants in order to investigate different neutron spectra (see Chapter 3). The temperature of the water is $307 \mathrm{C}$ and the densities are respectively $0.711 \mathrm{~g} / \mathrm{cc}$ and $0.791 \mathrm{~g} / \mathrm{cc}$ for light and heavy water (pressure $=155 \mathrm{bars}$ ). An important requirement related to the water is that its temperature coefficient must be negative, i.e. an increase of the water temperature, at constant pressure, must lead to a decrease of the reactivity and consequently of the power.

Different thermal-hydraulically "reasonable" water-to-fuel volume ratios have been considered by varying the lattice pitch while keeping the fuel rod radius constant: 2 (value corresponding to actual operating PWRs), 1 and 0.6. Certain groups investigated even tighter water-cooled lattices in the past (see for example [2.4]).

For the burnup calculations the flux level is normalized in a way such that the power density is equal to that of actual PWRs, i.e $100 \mathrm{~kW}_{\underline{t h}}$ /liter, independently of the water-to-fuel volume ratio, which implies that the specific and linear powers (expressed in, respectively, $\mathrm{kW}_{\mathrm{th}} / \mathrm{kg}_{\mathrm{HM}}$ and $\mathrm{kW}_{\mathrm{th}} / \mathrm{m}$ ) decrease with this ratio (Table 2.2). The determination of the optimal power density for the low water-to-fuel volume ratios (i.e. 1 and 0.6$)$ requires a thermal-hydraulic characterization of these cores under normal and accidental conditions. 
These important thermal-hydraulic aspects are not treated further in this document. However, since the specific and linear powers impact directly the neutron flux level, and that this level impacts the U233 build-up (the higher the flux, the higher the amount of Pa233) in a very case-specific way, a few calculations have been run with different specific powers for a given water-to-fuel volume ratio.

Table 2.2. Specific and linear powers (respectively in $\mathrm{kW}_{\mathrm{th}} / \mathrm{kg}_{\mathrm{HM}}$ and $\mathrm{kW}_{\mathrm{th}} / \mathrm{m}$ ) for the different water-to-fuel volume ratios considered. The power density is constant and equal to $100 \mathrm{~kW}_{\text {th }} /$ liter in all three cases.

\begin{tabular}{|c|c|c|c|c|}
\hline $\mathrm{V}_{\text {Water }} / \mathrm{V}_{\text {Fuel }}$ & $\begin{array}{c}\text { Rod Pitch/Rod Diameter } \\
(\mathrm{p} / \mathrm{d})\end{array}$ & $\begin{array}{c}\text { Specific Power } \\
\left(\mathrm{kW}_{\mathrm{th}} / \mathrm{kg}_{\mathrm{HM}}\right)\end{array}$ & $\begin{array}{c}\text { Linear Power } \\
\left(\mathrm{kW}_{\text {th }} / \mathrm{m}\right)\end{array}$ & $\begin{array}{c}\text { In-core HM } \\
\left(\mathrm{t}_{\mathrm{HM}} / \mathrm{GWe}\right)\end{array}$ \\
\hline 2.0 & 1.52 & 37 & 18 & 80 \\
\hline 1.0 & 1.27 & $26^{* *}$ & 13 & 113 \\
\hline 0.6 & 1.15 & $21^{* *}$ & 10 & 140 \\
\hline
\end{tabular}

* The rod diameter is equal to $9.5 \mathrm{~mm}$ independently of the water-to-fuel volume ratio.

** These values, though significantly smaller than that of standard PWRs (37 $\mathrm{kW}$ th/kg) are actually close to that in CANDUs and BWRs, i.e. respectively about $20 \mathrm{~kW} / \mathrm{kg}$ and $25 \mathrm{~kW}$ th $/ \mathrm{kg}$.

Taking into account the different specific powers given in Table 2.2, it takes about 1215, 1730 and 2140 Equivalent Full Power Days (EFPD) to reach a burnup of 45,000 MWd/t for, respectively, the water-to-fuel volume ratios of 2,1 and 0.6 .

The time between the end of the irradiation and the separation of the uranium from the irradiated fuel (cooling time + reprocessing time), which is usually taken as being between 5 and 10 years, as well as the time between the separation and the beginning of the next irradiation (fabrication and transportation times), which is usually taken as being between 1 and 2 years, have no effect when it comes to determine the amount of HEU that needs to be added to the recycled uranium because it does not impact its isotopic composition (that of the recycled uranium).

The reason is that the thorium, uranium and protactinium isotopes involved have half-lives that are either significantly smaller than 1 year or significantly larger than 10 years. The first category of isotopes decays quickly and there is nothing left after a year (e.g. Pa233 and U237), whereas the density of the isotopes belonging to the second category does not change noticeably whether the fuel is cooled 5 years or 10 years (e.g. U233, U235).

NB: This is different from the U-Pu cycle where the faster the plutonium is separated and reloaded into the reactor the better because the half-life of Pu241 (14.4 years) is of the same order of magnitude as the standard cooling times (5-10 years). Indeed, an irradiated fuel has about $27 \%$ more Pu241 after a 5-year cooling time than after a 10-year cooling time. 


\section{Heavy Water, Light Water and Neutron Spectrum - General Considerations}

All the nuclear reactors generating electricity throughout the world use a neutron moderator to slow down the neutrons from the fission energy down to the thermal energy in order to take advantage of the higher fission cross-section of U235 for thermal neutrons. The moderators used are either light water (PWR, BWR), heavy water (CANDU) or graphite (RBMK). Very early on, heavy water has been recognized as the best neutron moderator because of its very small neutron capture cross-section and because deuterium is one the lightest element, second only to hydrogen, hence allowing reaching criticality with natural uranium. Light water, even though made up of the lightest element, hydrogen, is not considered as good of a moderator because its much higher neutron capture cross-section necessitates a higher fissile content than when heavy water is used (CANDU can operate with natural uranium whereas PWRs cannot).

However, even though its high neutron capture cross-section, light water is the first choice if one wants to operate a compact thermal neutron reactor. Indeed, in the slowing-down region, between about $100 \mathrm{keV}$ and $0.1 \mathrm{eV}$, the neutron elastic scattering cross-section of hydrogen is about 20 barns whereas that of deuterium and carbon are both only about 4 barns. Furthermore, neutron slowing down theory shows that, on average, it takes a neutron only about 15 collisions with hydrogen nuclei to go from $2 \mathrm{MeV}$ down to $1 \mathrm{eV}$ whereas it takes about 20 and 90 collisions with, respectively deuterium and carbon. These different slowing-down properties of light water, heavy water and graphite are responsible for the different sizes of the PWRs, CANDUs and RBMKs; for the same power CANDUs and RBMKs need to be larger than PWRs to allow enough space f or the neutrons to slow down to the thermal energy.

Hence, if in a standard PWR lattice, light water is replaced by the same volume of heavy water the resulting neutron spectrum will be substantially harder (Figure 3.1) even though heavy water is considered a better moderator than light water. Figure 3.1 represents the neutron flux as a function of energy in a standard $4 \%$ enriched $\mathrm{UO}_{2} \mathrm{PWR}$ lattice $\left(\mathrm{H}_{2} \mathrm{O}\right.$-to-fuel volume ratio $\left.=2\right)$ as well as in the same lattice but with $\mathrm{D}_{2} \mathrm{O}$ instead of $\mathrm{H}_{2} \mathrm{O}$ and demonstrates the hardening of the neutron spectrum. As it will be shown in Chap. 6, the neutron spectrum in a tight-pitch heavy-water-cooled lattice is closer to that of a fast reactor than to that of a thermal reactor.

Furthermore, if light water is nearly costless, things are different when it comes to produce heavy water. With this regard it is worthwhile noting that the reactors investigated here could fit in a vessel the size of that of standard PWR and since heavy water and light water are equivalent from a T/H point of view, the rest of the primary circuit (pressurizer, steam generators, pumps and pipes) would be the same. For comparison, the heavy water inventory in a CANDU is about 750 tons per GWe [3.1] (includes the heavy water acting as moderator in the calendria, and the heavy water in the pressurized heat transport system) 
whereas the light water inventory in the primary circuit of a standard 1 GWe PWR is about half that amount [3.2]. Hence, for the same power, the heavy water reactors investigated here contain only about half the heavy water present in a CANDU reactor.

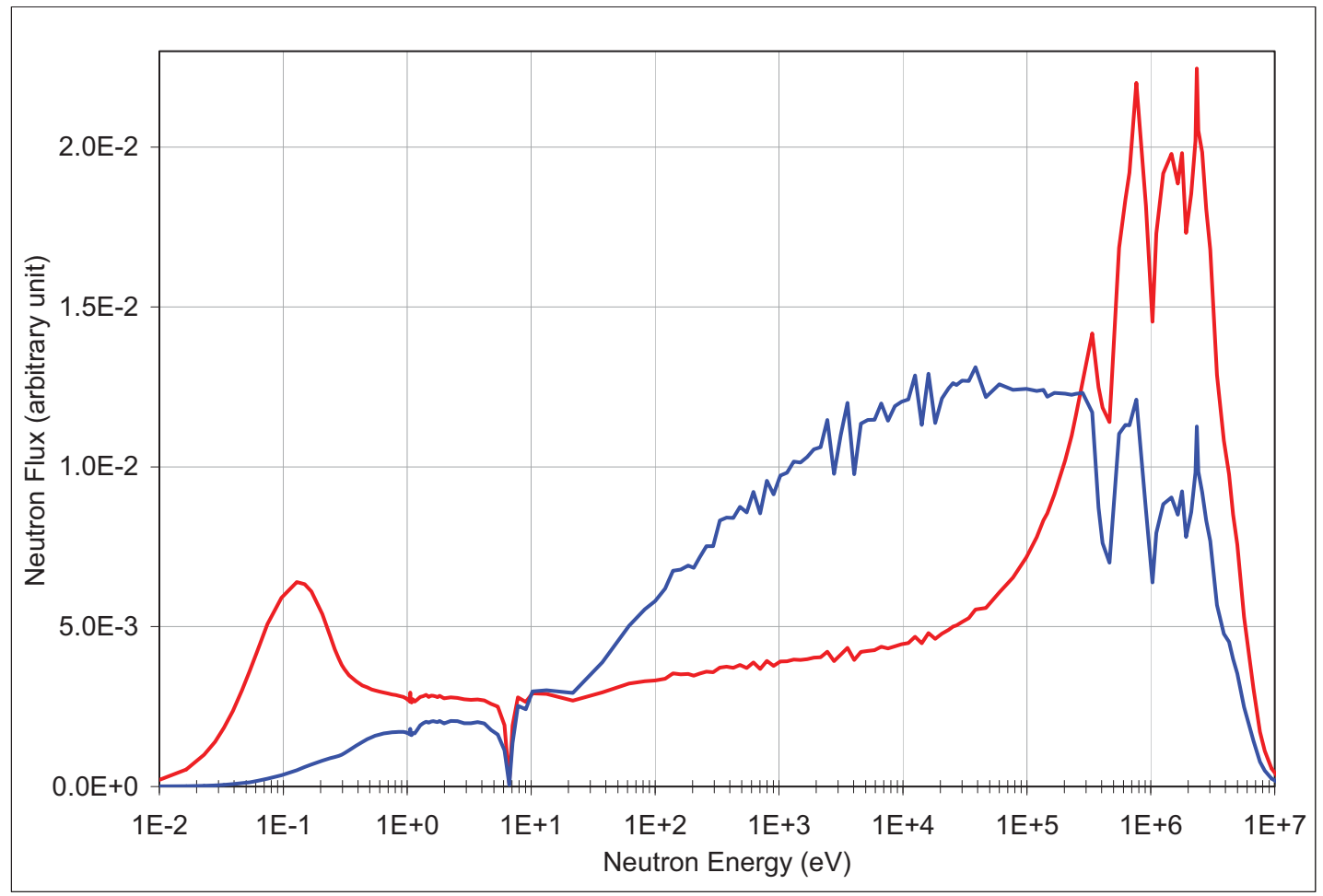

Figure 3.1. Neutron flux as a function of energy in a standard $4 \%$ enriched $\mathrm{UO}_{2} \mathrm{PWR}$ lattice (red) as well as in the same lattice but with $\mathrm{D}_{2} \mathrm{O}$ instead of $\mathrm{H}_{2} \mathrm{O}$ (blue)

Another factor impacting the cost of heavy water is its purity. As it will be shown later, the heavy water reactors investigated here do not need a $99.75 \%$ purity like the CANDU reactors. As a matter of fact, it is sometimes necessary to have a few percent of $\mathrm{H}_{2} \mathrm{O}$ mixed with the $\mathrm{D}_{2} \mathrm{O}$ in order to ensure a negative water temperature coefficient.

Finally, an important issue associated to the use of heavy water is the production of tritium by neutron capture on deuterium. This neutron capture has a characteristic $1 / \mathrm{v}$ shape and consequently decreases as the neutron energy increases; it is comprised between about $10^{-4}$ barn and $10^{-3}$ barn in the thermal energy range $(0.001 \mathrm{eV}-1 \mathrm{eV})$ whereas for neutron energies above $100 \mathrm{eV}$ it is between about $10^{-5}$ barn and $10^{-6}$ barn. In CANDU reactors, tritium can contribute a large portion of station dose. Historically, it has been responsible for 30 to $40 \%$ of the radiation dose received by nuclear station staff [3.3]. Because the neutron spectra of the heavy water reactors investigated here are much harder than that of a CANDU the production of tritium should be orders of magnitude smaller. 


\section{The Reference $\mathrm{UO}_{2}$ reactor}

The reference $1 \mathrm{GWe} \mathrm{UO}_{2}$ reactor is characterized by a water-to-fuel volume ratio equal to 2 and it generates 8 TWhe per year (load factor $=91.3 \%$ ). It needs about $19.2 t_{\text {HM }}$ of LEU $(4.3 \%$ U235) fuel per year (burnup $=51,000 \mathrm{MWd} / \mathrm{t}_{\mathrm{HM}}$ ) which translates to a natural uranium consumption of about $169 \mathrm{t}_{\mathrm{HM}}$ of per year (Figure 4.1).

The amount of TRU (Pu, Np, Am and $\mathrm{Cm}$ ) in the spent $\mathrm{UO}_{2}$ fuel is about $13 \mathrm{~kg} / \mathrm{tlHM}$. It is made up of about $87.5 \%$ of $\mathrm{Pu}, 5 \%$ of $\mathrm{Np}, 7 \%$ of $\mathrm{Am}$ and $0.5 \%$ of $\mathrm{Cm}$. The detail of the TRU production is given in the Appendix $\mathrm{C}$ (column $\mathrm{UO}_{2}$ present in each of the tables). The annual production of Fission Products (FP) and TRU are respectively 1.0 ton and 0.25 ton.

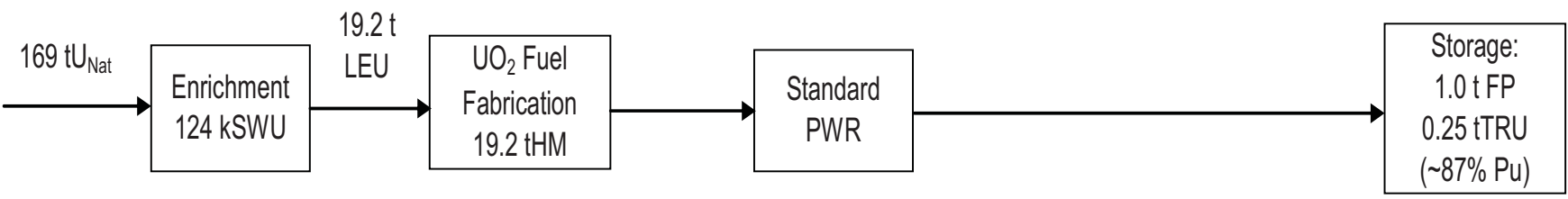

Figure 4.1. Static equilibrium annual mass flows for the reference $1 \mathrm{GWe} \mathrm{UO}_{2} \mathrm{PWR}$.

$$
\text { Burnup }=51,000 \mathrm{MWd} / \mathrm{t}_{\text {Hм }} . \text { Energy }=8 \mathrm{TWhe} .
$$




\section{The light-water-cooled $(\mathrm{Th}-\mathrm{U}) \mathrm{O}_{2}$ reactors}

The burnup considered here is equal to $45,000 \mathrm{MWd} / \mathrm{t}(3 \times 15,000 \mathrm{MWd} / \mathrm{t})$.

Core physics aspects. The percentages of HEU for the first cycles are $4.9 \%, 6.3 \%$ and $9.7 \%$ for, respectively, the water-to-fuel volume ratios of 2,1 and 0.6 . The reactivity losses per cycle $(15,000$ $\mathrm{MWd} / \mathrm{t})$ are, respectively, about $10,000 \mathrm{pcm}, 7,500 \mathrm{pcm}$ and $4,500 \mathrm{pcm}$. The water temperature coefficients are strongly negative: between -30 and $-40 \mathrm{pcm} /{ }^{\circ} \mathrm{C}$ for the water-to-fuel volume ratio of 2 and between -60 and $-70 \mathrm{pcm} /{ }^{\circ} \mathrm{C}$ for the water-to-fuel volume ratios of 1 and 0.6 .

The neutron flux as a function of energy calculated for the first cycle and for the three water-to-fuel volume ratios is shown on Figure 5.1 below. Given the respective specific powers presented in Table 2.2, the total flux is about $3 \times 10^{14} \mathrm{n} . \mathrm{cm}^{-2} . \mathrm{s}^{-1}$ for the three water-to-fuel volume ratios $\left(3.1 \times 10^{14}, 3.3 \times 10^{14}\right.$ and $3.6 \times 10^{14}$ for the volume ratios of 2,1 and 0.6$)$.

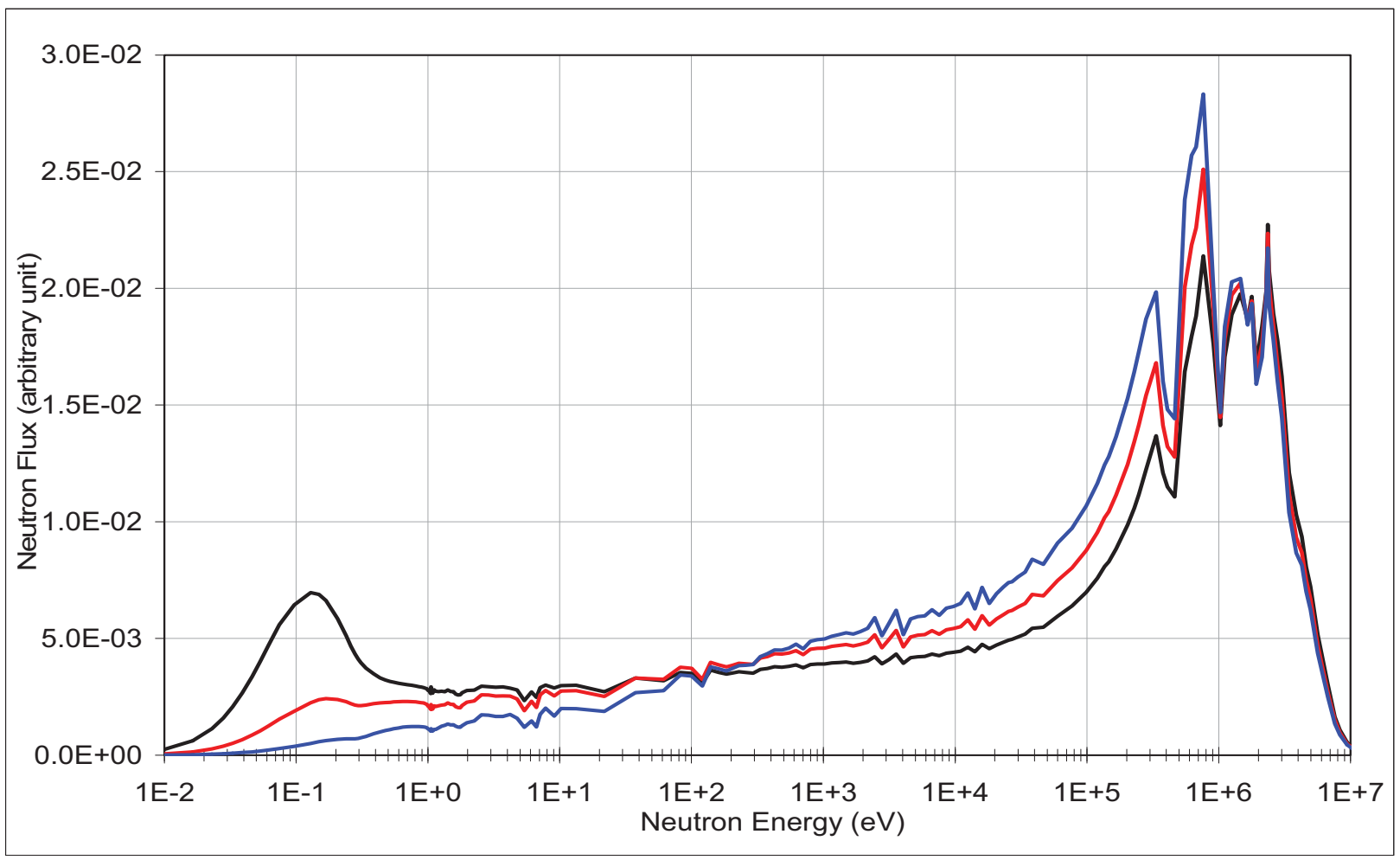

Figure 5.1. Neutron flux as a function of energy and for water-to-fuel volume ratios of 2 (black), 1 (red) and 0.6 (blue) - Light-water-cooled cases. 
Evolution of $\mathrm{U}$ isotopic concentrations during recycling. Figures 5.2 (a to $\mathrm{c}$ ) show the evolution of the $\mathrm{U}$ isotopic concentrations during recycling and for the three water-to-fuel volume ratios $(2,1$ and 0.6$)$. The addition of HEU at each cycle is clearly seen (U235 spikes). As the isotopic composition of the $U$ evolves, its total concentration increases. Whereas it is between $49 \mathrm{~kg} / \mathrm{tlHM}$ and $97 \mathrm{~kg} / \mathrm{tlHM}$ for the first cycle, it increases to between $90 \mathrm{~kg} / \mathrm{tIHM}$ and $115 \mathrm{~kg} / \mathrm{tlHM}$ at the $10^{\text {th }}$ cycle. The $\mathrm{U} 233$ concentration reaches an equilibrium value after 2-3 cycles (between $15 \mathrm{~kg} / \mathrm{tlHM}$ and $35 \mathrm{~kg} / \mathrm{tlHM}$ ). On the other hand, the U236 concentration does not reach an equilibrium and it increases almost linearly with the number of recycling. The U232 concentration reaches an equilibrium as well at about $0.1 \mathrm{~kg} / \mathrm{tlHM}$ which corresponds to a ratio U232/Utot of about $1000 \mathrm{ppm}$. The issues associated with the presence of U232 are presented in the Appendix A.

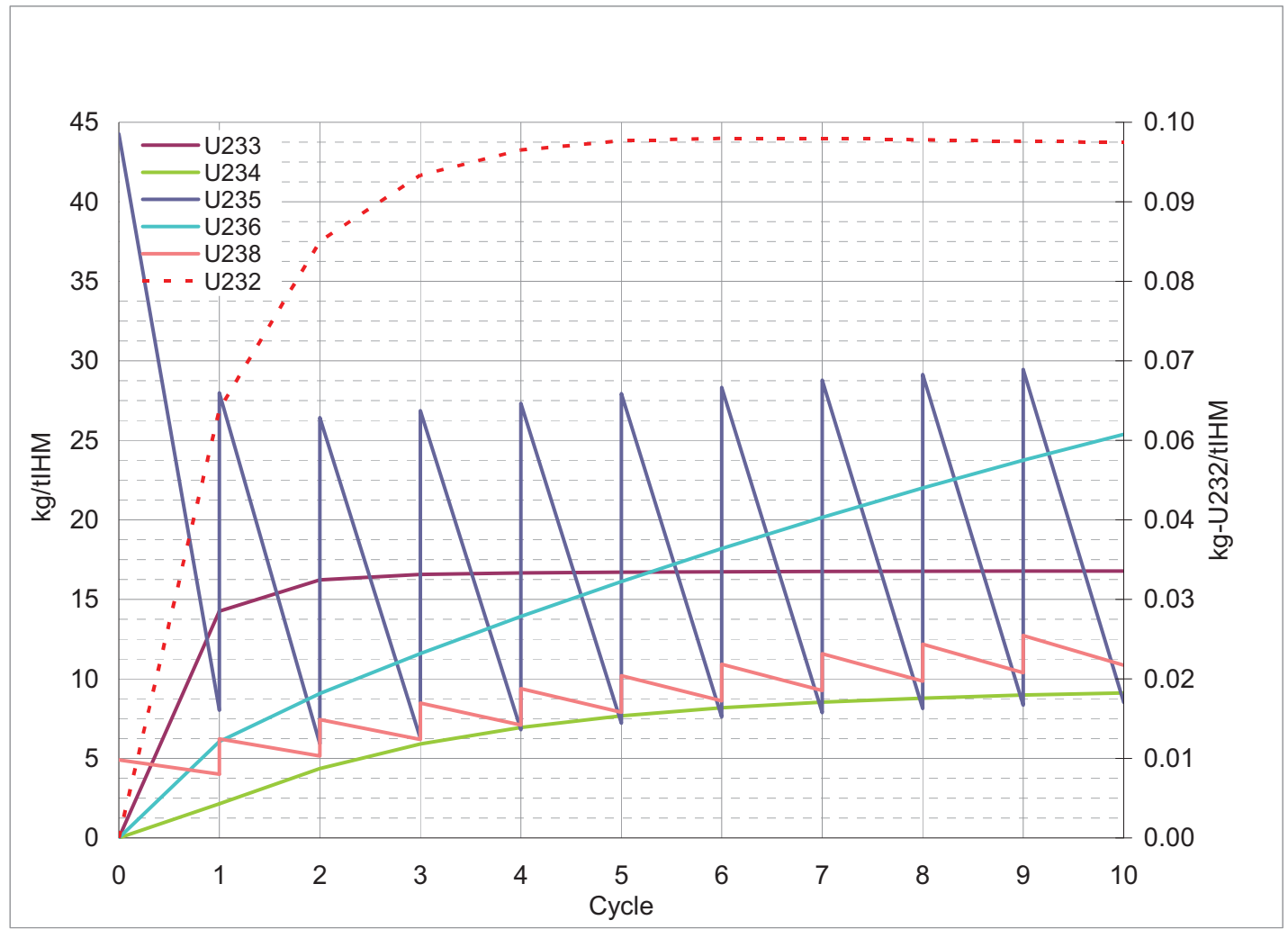

Figure 5.2a. Evolution of $U$ concentration at fabrication and reprocessing of the Th- $U$ fuel $(\mathrm{kg} / \mathrm{tlHM})$. Water-to-fuel volume ratio $=2$. Burnup $=45,000 \mathrm{MWd} / \mathrm{t}_{\text {HM }}$. Light-water-cooled case.

The amount of TRU that needs to be disposed of increases from about 1 to $2.5 \mathrm{~kg} / \mathrm{tlHM}$ for the first recycling to about 3.5 to $5.5 \mathrm{~kg} / \mathrm{tlHM}$ for the $10^{\text {th }}$ recycling. Neptunium accounts for about $45 \%-55 \%$ of the TRU produced and Pu for about 40\%-45\%. Furthermore, whereas Pu238 usually makes up less than 5\% of the total $\mathrm{Pu}$ in $\mathrm{UO}_{2}$ spent fuel, here it makes up about half of it. The details of TRU production are given in the Appendix C, Tables C.1 to C.3. 


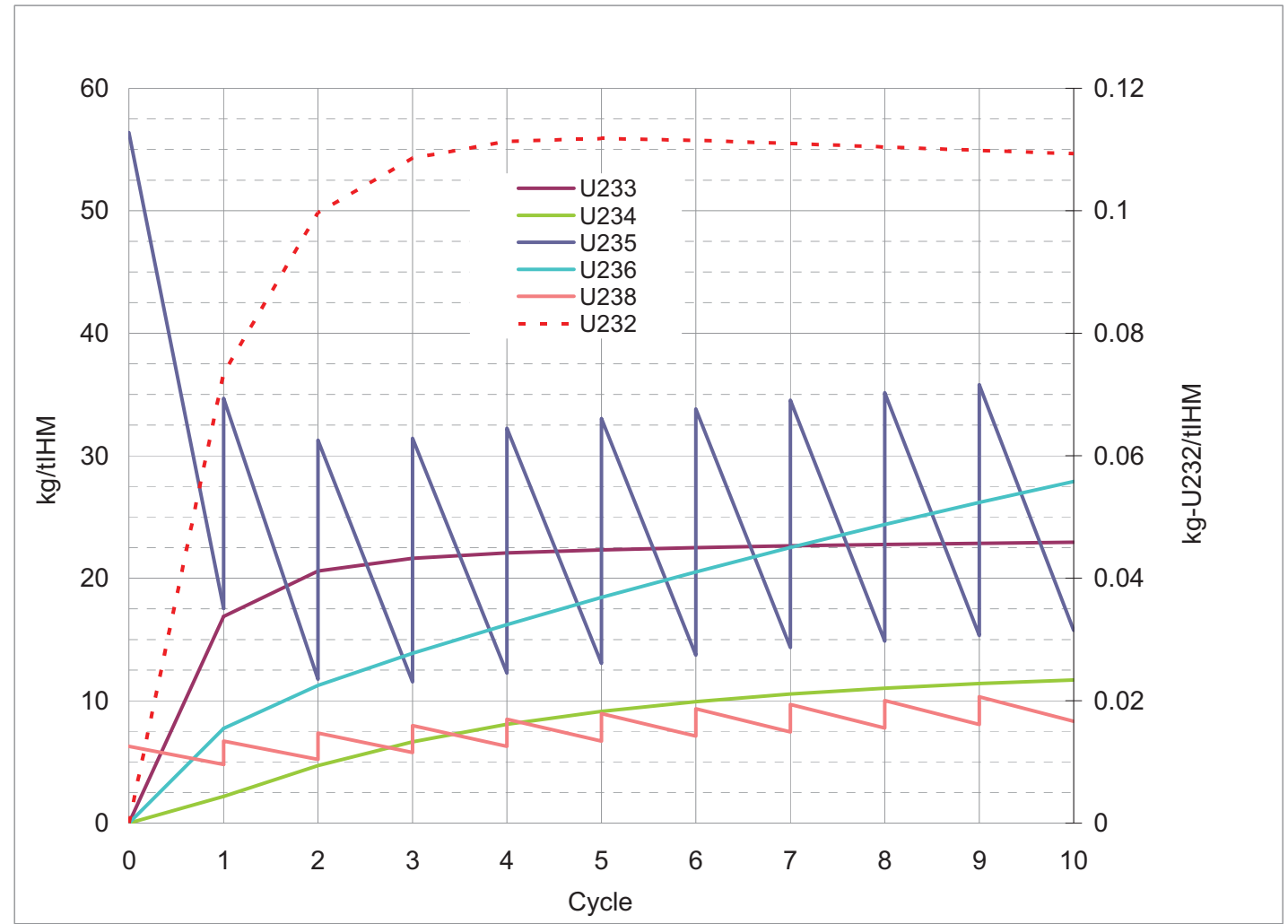

Figure 5.2b. Evolution of $U$ concentration at fabrication and reprocessing of the Th- $U$ fuel $(\mathrm{kg} / \mathrm{tl} \mathrm{HM})$. Water-to-fuel volume ratio $=1$. Burnup $=45,000 \mathrm{MWd} / \mathrm{t}_{\mathrm{HM}}$. Light-water-cooled case.

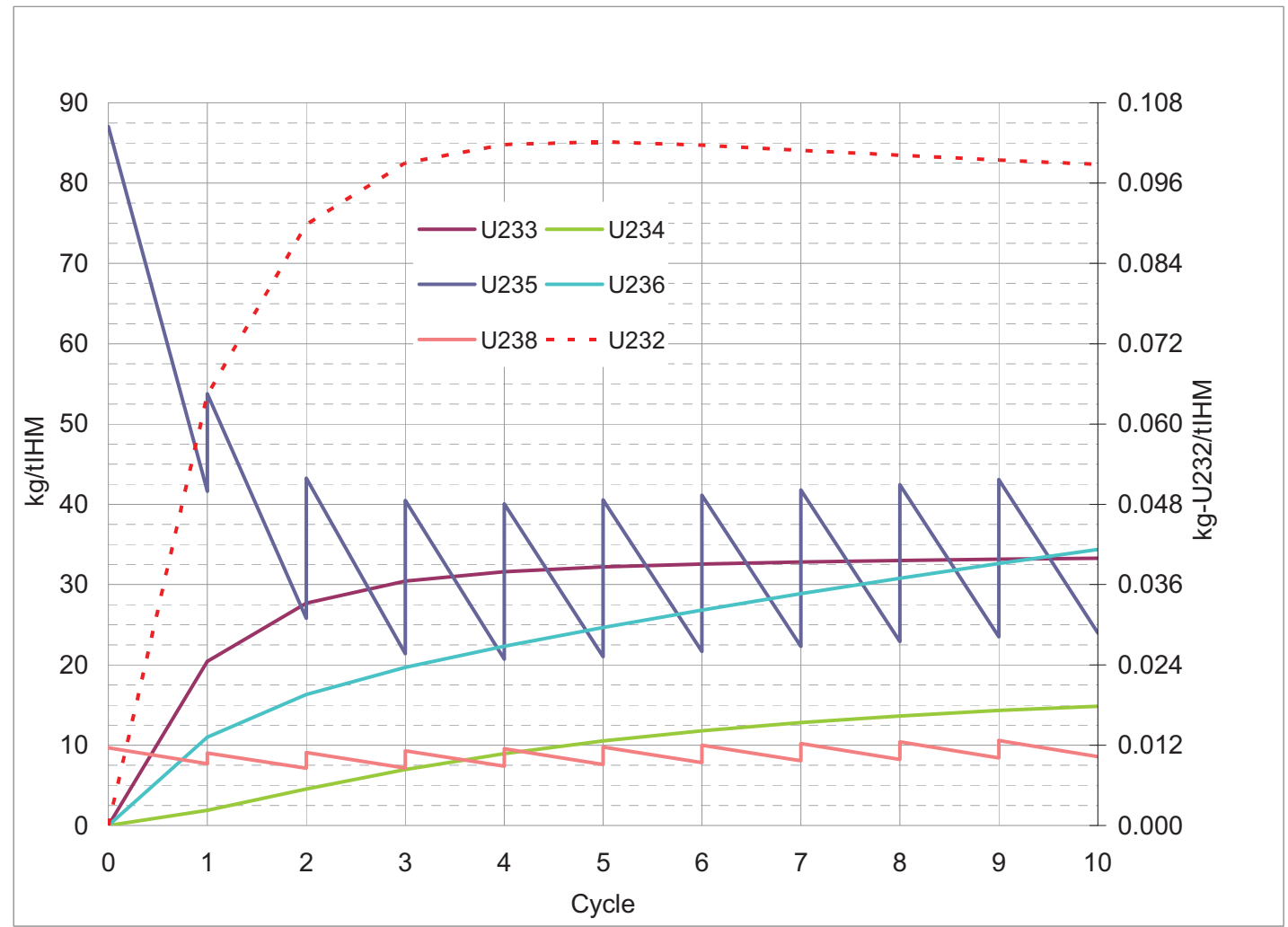

Figure 5.2c. Evolution of $U$ concentration at fabrication and reprocessing of the Th- $U$ fuel $(\mathrm{kg} / \mathrm{tlHM})$. Water-to-fuel volume ratio $=0.6$. Burnup $=45,000 \mathrm{MWd} / \mathrm{t}_{\text {HM }}$. Light-water-cooled case. 
The heat load associated to these TRU is presented in Appendix D (Figures D.1 \& D.2). For the water-tofuel volume ratio of 2, it increases with the recyclings as the amount of Pu238 in the fuel increases, but always stays below that produced by a $\cup_{2}$ fuel. For the first recycling, the heat load is between 5 and 25 times smaller than that of the $\mathrm{UO}_{2}$ fuel for times after discharge comprised between 50 years and 10,000 years. For the $10^{\text {th }}$ recycling, it is between 1.2 and 12 times smaller than that of the $\mathrm{UO}_{2}$ fuel. The heat load is somewhat higher with the water-to-fuel volume ratio of 0.6 as the amount of Pu238 is higher.

Mass Flows. Figure 5.3 below presents the annual mass flows for the $10^{\text {th }}$ cycle for a Th-U reactor characterized by a standard water-to-fuel volume ratio of 2 as well as for water-to-fuel volume ratios of 1 and 0.6. As mentioned in the introduction, the amount of $\mathrm{U} 233$ created is not sufficient to maintain a burnup of $45,000 \mathrm{MWd} / \mathrm{t}$ and consequently it is necessary to add about 0.5 tons of HEU per GWe.year at each cycle.

Depending on the water-to-fuel volume ratio, between 1.5 tons and 2.5 tons of $U$ are reprocessed per GWe.year. These Th-U fuels produce between 2 and 3.5 times less TRU than the reference $\mathrm{UO}_{2}$ reactor. Furthermore, whereas the TRU contained in $\mathrm{UO}_{2}$ spent fuel is essentially made up of $\mathrm{Pu}(87 \%)$, the TRU produced by the Th-U fuel is made up of about $55 \% \mathrm{~Np} 237$.

Compared with the reference $\mathrm{UO}_{2}$ reactor the Th-U reactors need between $40 \%$ and $45 \%$ less natural $\mathrm{U}$. The influence of the water-to-fuel volume ratio is not very large and, as far as natural $U$ utilization goes, there is not a strong incentive to use a tight lattice when $\mathrm{H}_{2} \mathrm{O}$ is the coolant, especially if one takes into account the fact the initial inventory in the tight lattice cores are higher than that in the standard lattice core (water-to-fuel volume ratio of 2). Indeed, taking into account the specific powers given in $\underline{\text { Table 2.2 }}$, the initial HEU inventory in the core with a water-to-fuel volume ratio of 0.6 is about 3.5 times higher than that in the standard core (140 tons $\times 9.7 \%$ instead of 80 tons $\times 4.9 \%)$.

These numbers are calculated considering $0 \% \cup$ reprocessing losses. The impact of the reprocessing losses is treated in Chap. 8. 


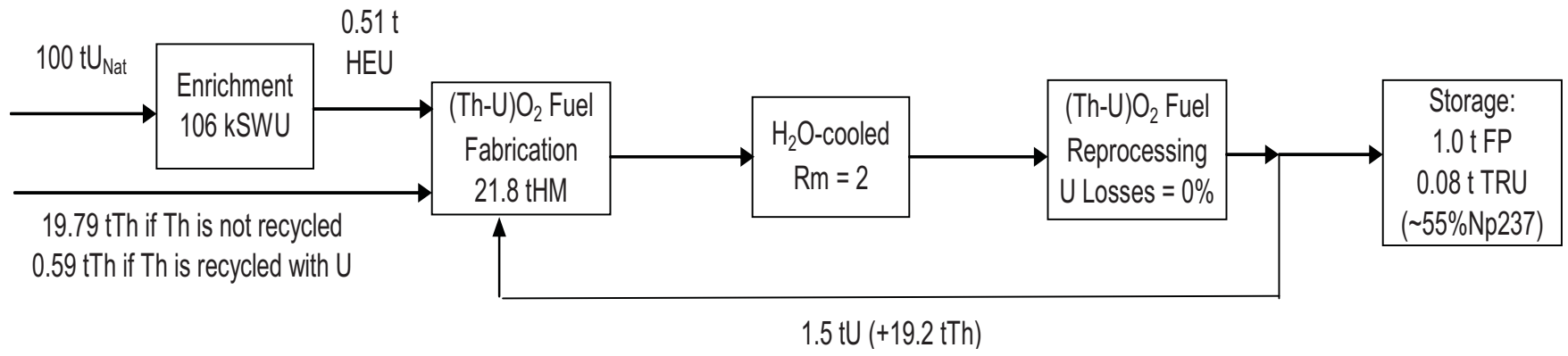

(a)

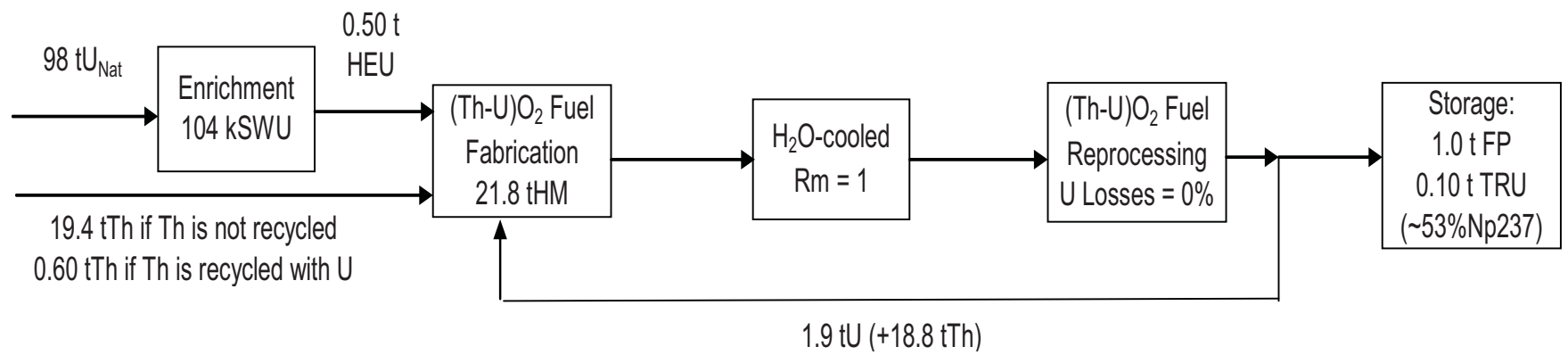

(b)

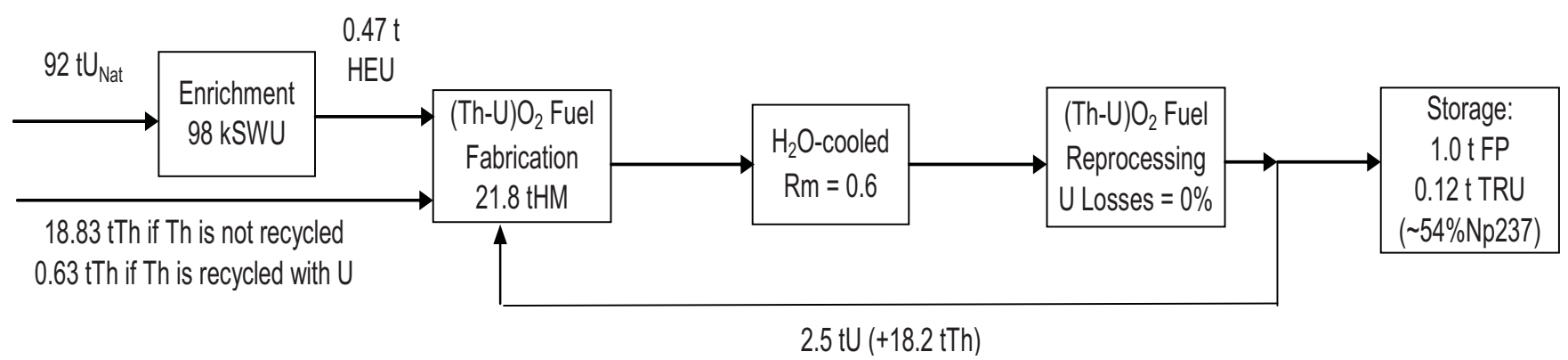

(c)

Figure 5.3. Static equilibrium annual mass flows for $1 \mathrm{GWe}$ light-water-cooled Thorium reactors with water-to-fuel volume ratios of 2 (a), 1 (b) and 0.6 (b). Burnup $=45,000 \mathrm{MWd} / \mathrm{t}_{\mathrm{HM}}$. Energy $=8 \mathrm{TWhe}$. 


\section{The heavy-water-cooled $(\mathrm{Th}-\mathrm{U}) \mathrm{O}_{2}$ reactors}

\subsection{Burnup $=45,000 \mathrm{MWd} / \mathrm{t}$}

Core physics aspects. The percentages of HEU for the first cycle are higher than those obtained with light water and are not very dependant on the water-to-fuel volume ratio: $17.8 \%, 17.6 \%$ and $16.8 \%$ for volume ratios of, respectively 2,1 and 0.6 . The reactivity losses per cycle $(15,000 \mathrm{MWd} / \mathrm{t})$ are between 2000 and $3500 \mathrm{pcm}$ for the water-to-fuel volume ratio of 2, between 800 and $1800 \mathrm{pcm}$ for the water-tofuel volume ratio of 1 and between 300 and 700 pcm for the water-to-fuel volume ratio of 0.6 .

The water temperature coefficients are negative: between -10 and $-30 \mathrm{pcm} /{ }^{\circ} \mathrm{C}$ and between 0 and -15 $\mathrm{pcm} /{ }^{\circ} \mathrm{C}$ for, respectively, the water-to-fuel volume ratios of 2 and 1 . For the water-to-fuel volume ratio of 0.6 , some light water must be mixed to the heavy water in order to maintain a negative water temperature coefficient. Depending on the cycle between $5 \%$ and $2 \% \mathrm{H}_{2} \mathrm{O}$ are necessary and the water temperature coefficient is between 0 and $-10 \mathrm{pcm} /{ }^{\circ} \mathrm{C}$.

The neutron flux as a function of energy calculated for the first cycle and for the three water-to-fuel volume ratios is shown on Figure 6.1.1 below. Given the respective specific powers presented in Table 2.2, the total flux is about $6 \times 10^{14} \mathrm{n} . \mathrm{cm}^{-2} \cdot \mathrm{s}^{-1}$ for the three water-to-fuel volume ratios $\left(6.0 \times 10^{14}\right.$ for the volume ratios of 2 and $1,5.8 \times 10^{14}$ for the volume ratios of 0.6 ). Such a high flux might necessitate the use of a steel cladding instead of a zircaloy cladding (not considered here).

Evolution of $U$ isotopic concentrations during recycling. Figures 6.1.2 (a to $\mathrm{c}$ ) show the evolution of the $U$ isotopic concentrations during recycling and for the three water-to-fuel volume ratios $(2,1$ and 0.6$)$. Just as with light water, the addition of HEU at each cycle is clearly seen as well. The total $U$ concentration is higher than for the light water cases but on the other hand it does not increase as much with recyclings: it is comprised between about $150 \mathrm{~kg} / \mathrm{tlHM}$ and $190 \mathrm{~kg} / \mathrm{tlHM}$. The U233 concentrations reach higher equilibrium values than those reached with light water, i.e. between about $70 \mathrm{~kg} / \mathrm{tlHM}$ and 90 $\mathrm{kg} / \mathrm{tlHM}$. On the other hand, the U232 concentrations reach lower equilibrium values (between 0.04 and $0.06 \mathrm{~kg} / \mathrm{tlHM}$ ) than those reached with light water which corresponds to ratios U232/Utot of between 200 ppm and 400 ppm. The issues associated with the presence of U232 are presented in the Appendix A.

The amount of TRU that needs to be disposed of increases from about 2 to $3 \mathrm{~kg} / \mathrm{tlHM}$ for the first recycling to about 3 to $6.5 \mathrm{~kg} / \mathrm{tIHM}$ for the $10^{\text {th }}$ recycling. Neptunium accounts for about $30 \%-60 \%$ of the TRU produced and Pu for about 35\%-65\%. Furthermore, whereas Pu238 usually makes up less than 5\% of the total $\mathrm{Pu}$ in $\mathrm{UO}_{2}$ spent fuel, here it makes up between a quarter to a third of it. The details of TRU production are given in the Appendix C, Tables C.4 to C.6. 


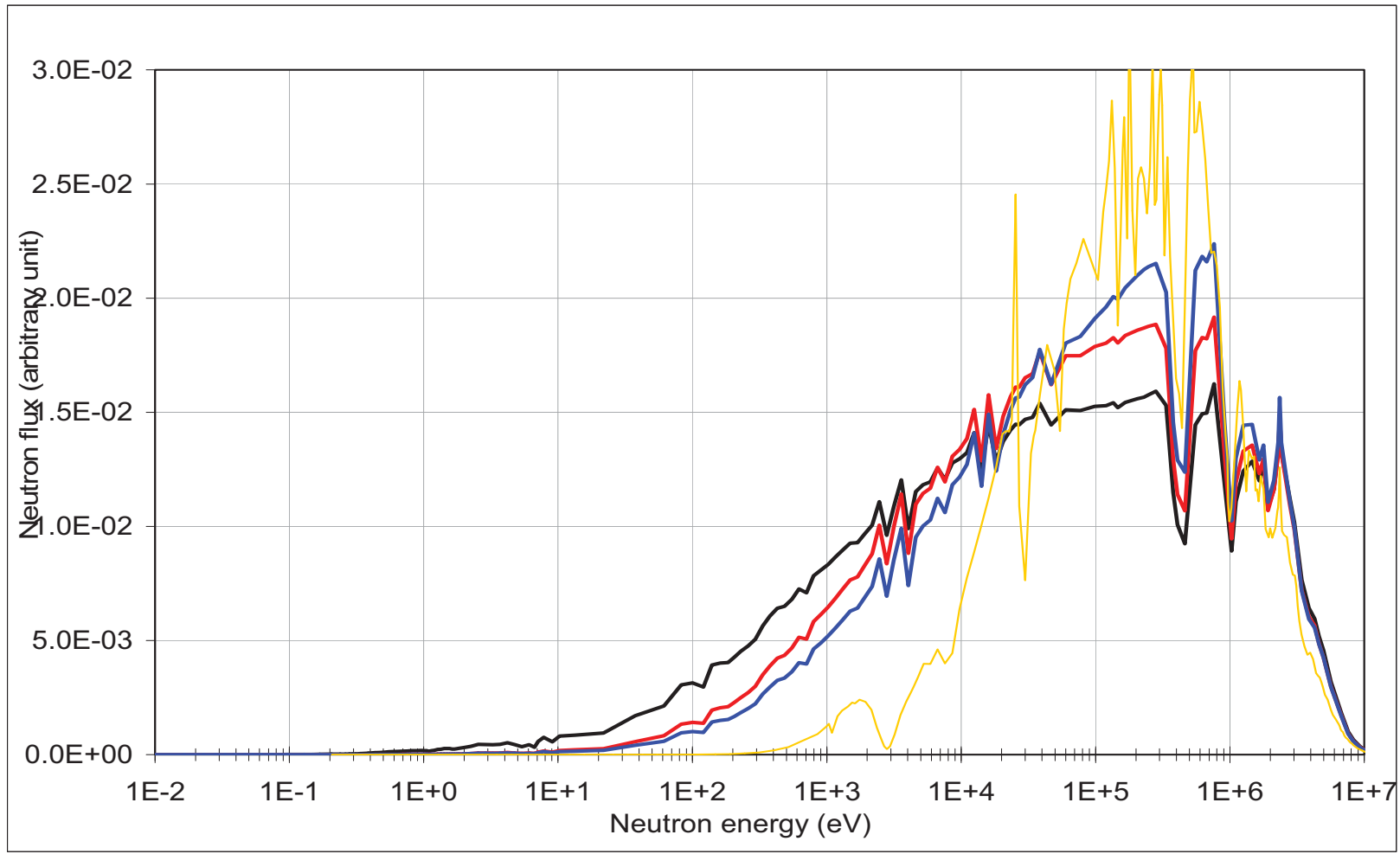

Figure 6.1.1a. Neutron flux as a function of energy and for water-to-fuel volume ratios of 2 (black), 1 (red) and 0.6 (blue) - Heavy-water-cooled cases. The neutron flux in a large sodium-cooled oxide-fueled fast reactor is shown for comparison (orange, G. Palmiotti, personal communication [6.1]).

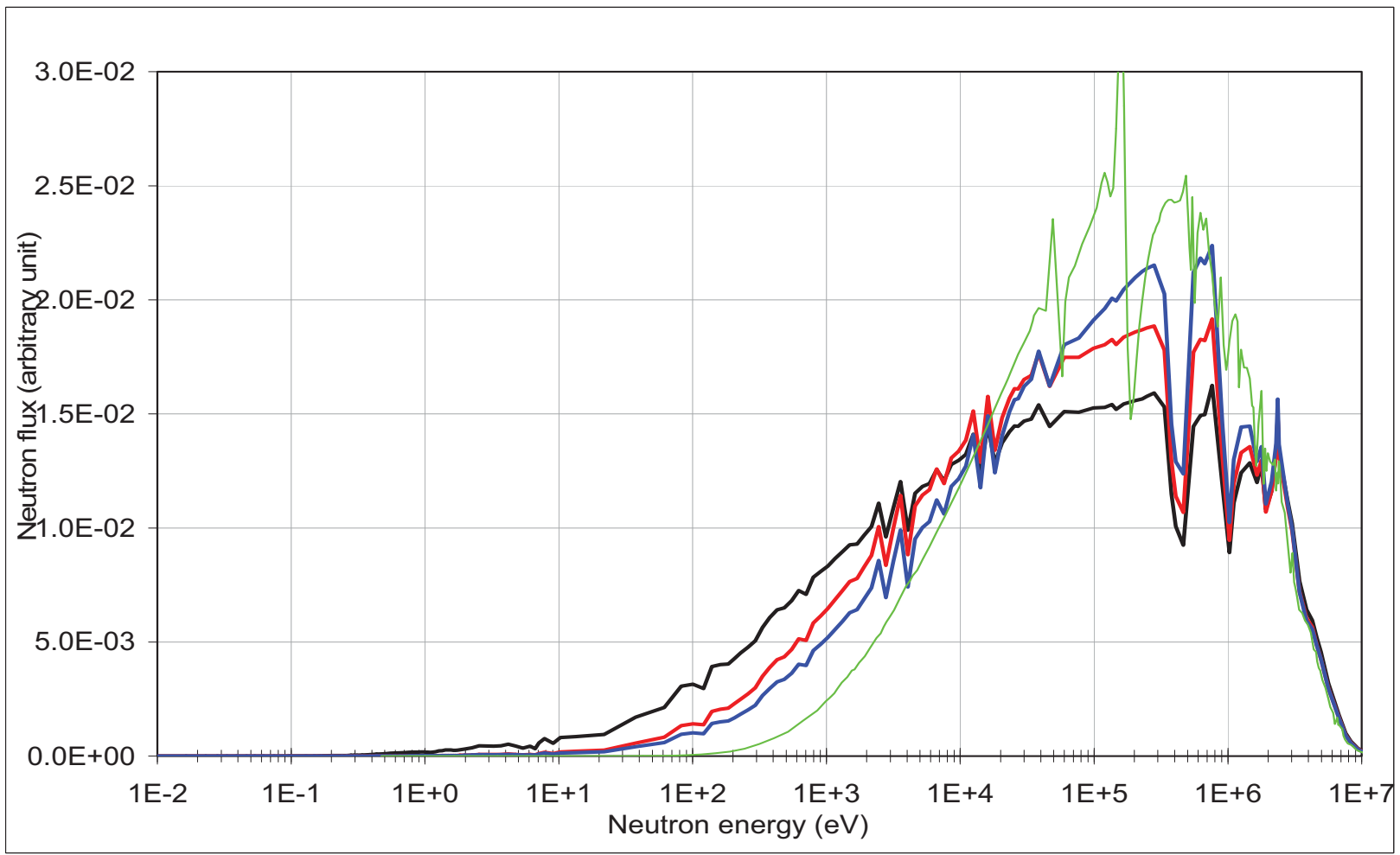

Figure 6.1.1b. Neutron flux as a function of energy and for water-to-fuel volume ratios of 2 (black), 1 (red) and 0.6 (blue) - Heavy-water-cooled cases. The neutron flux in a large gas-cooled fast reactor is shown for comparison (green, G. Palmiotti, personal communication [6.1]). 


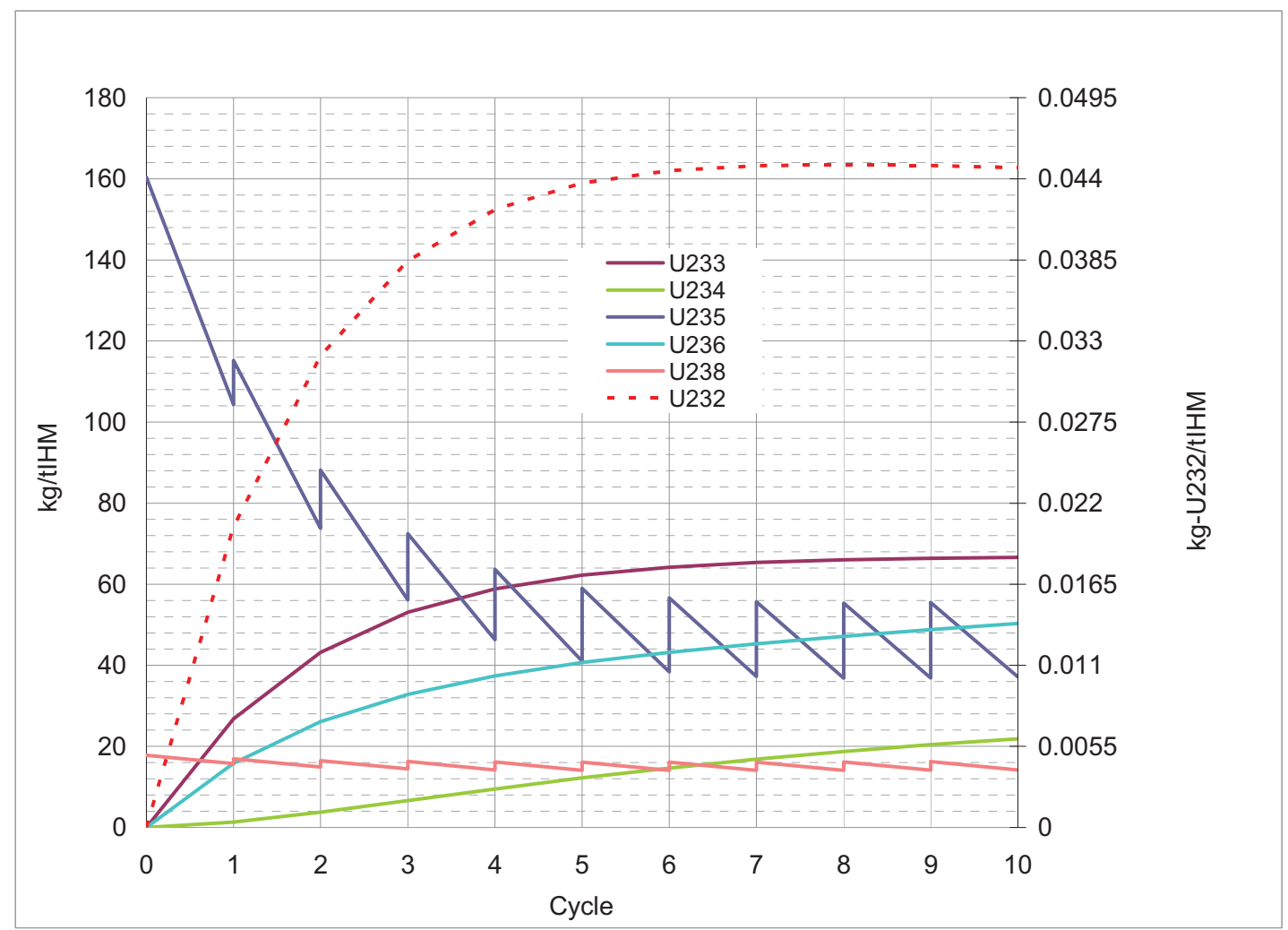

Figure 6.1.2a. Evolution of $U$ concentration at fabrication and reprocessing of the Th- $U$ fuel $(\mathrm{kg} / \mathrm{tlHM})$. Water-to-fuel volume ratio $=2$. Burnup $=45,000 \mathrm{MWd} / \mathrm{t}_{\mathrm{HM}}$. Heavy-water-cooled case.

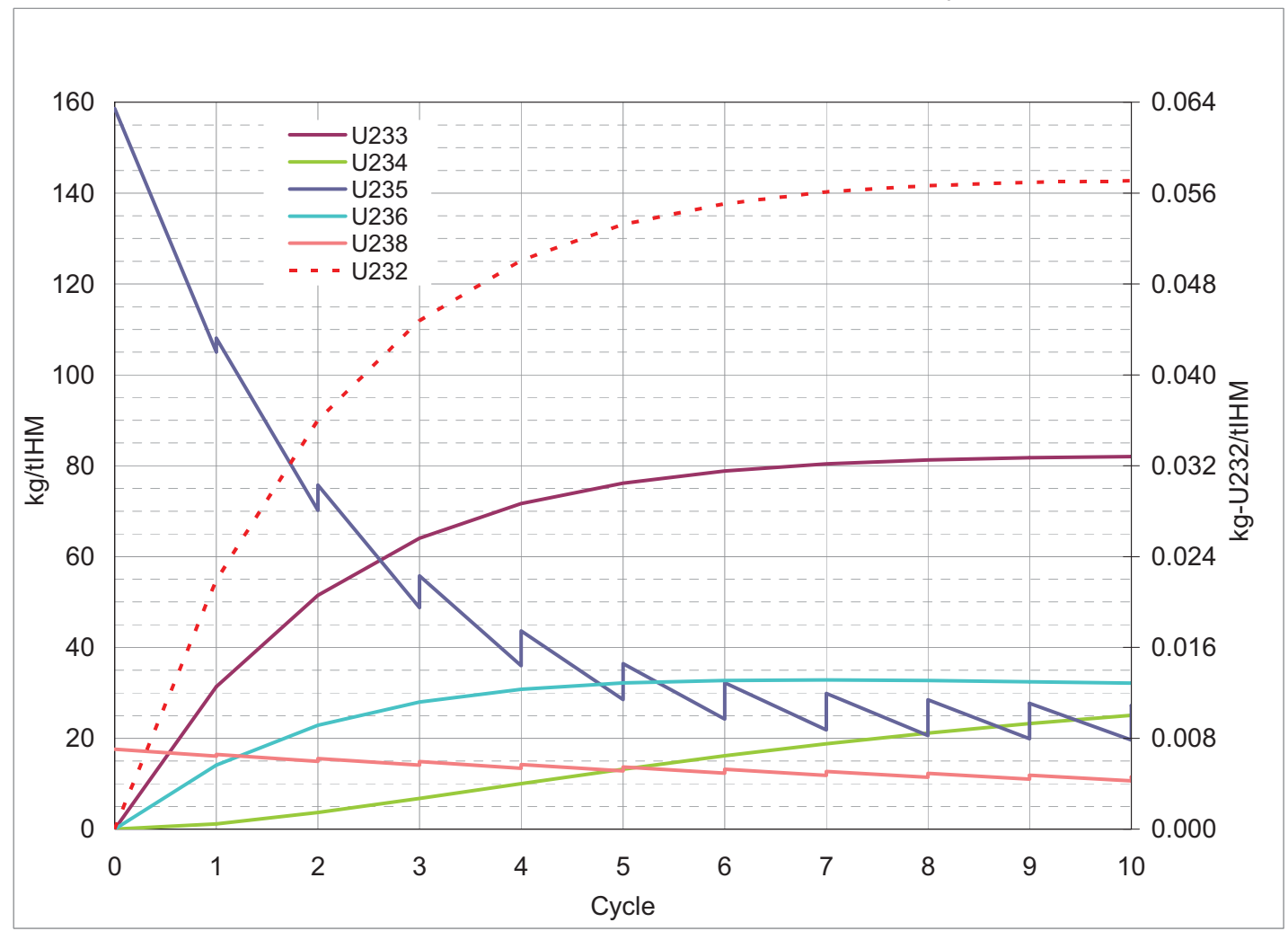

Figure 6.1.2b. Evolution of $U$ concentration at fabrication and reprocessing of the Th- $U$ fuel $(\mathrm{kg} / \mathrm{tlHM})$. Water-to-fuel volume ratio $=1$. Burnup $=45,000 \mathrm{MWd} / \mathrm{t}_{\mathrm{HM}}$. Heavy-water-cooled case. 


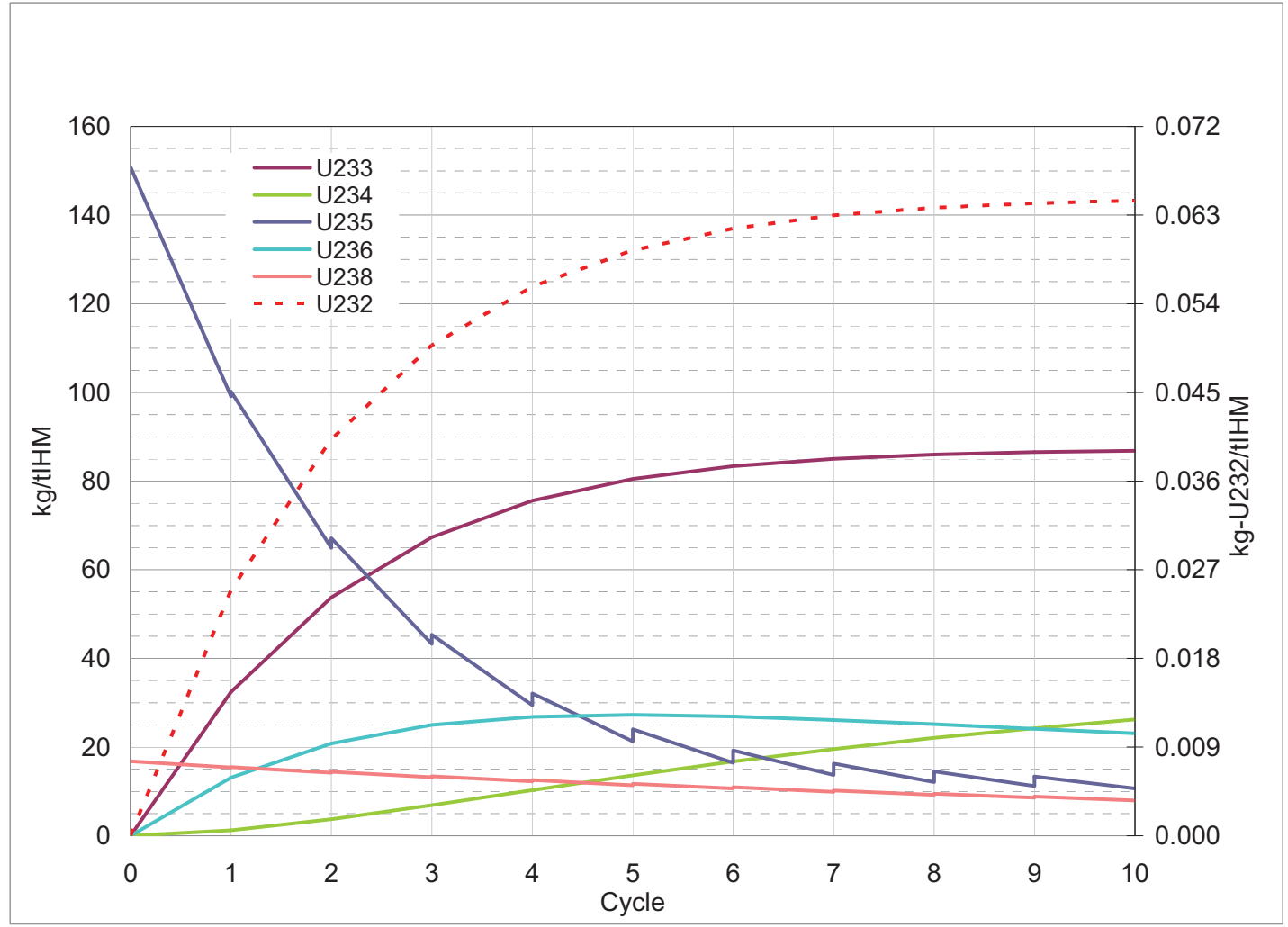

Figure 6.1.2c. Evolution of $U$ concentration at fabrication and reprocessing of the Th- $U$ fuel $(\mathrm{kg} / \mathrm{tl} \mathrm{HM})$. Water-to-fuel volume ratio $=0.6$. Burnup $=45,000 \mathrm{MWd} / \mathrm{t}_{\mathrm{HM}}$. Heavy-water-cooled case.

The heat load associated to these TRU is presented in Appendix D (Figures D.3 \& D.4). It is higher in the lattice with the water-to-fuel volume ratio of 1 than in the lattice with the water-to-fuel volume ratio of 0.6 because the amount of Pu238 is about a factor of two higher. For both water-to-fuel volume ratios it increases with the recyclings but always stays below that produced by a $\mathrm{UO}_{2}$ fuel. For the water-to-fuel volume ratio of 0.6 , and for the first recycling, the heat load is between 5 and 25 times smaller than that of the $\mathrm{UO}_{2}$ fuel for times after discharge comprised between 100 years and 10,000 years. For the $10^{\text {th }}$ recycling, it is between 3 and 17 times smaller than that of the $\mathrm{UO}_{2}$ fuel.

Mass Flows. Figure 6.1.3 below presents the annual mass flows for the $10^{\text {th }}$ cycle for a Th-U reactor characterized by a water-to-fuel volume ratio of 2 as well as for water-to-fuel volume ratios of 1 and 0.6. As before, the amount of $\mathrm{U} 233$ created is not sufficient to maintain a burnup of $45,000 \mathrm{MWd} / \mathrm{t}$ and consequently it is necessary to add HEU at each cycle (depending on the water-to-fuel volume ratio, between about 0.5 tons and 0.05 tons per GWe.year).

Depending on the water-to-fuel volume ratio, between 3.4 tons and 4.1 tons of $U$ are reprocessed per GWe.year. These Th-U fuels produce between 1.5 and 3.5 times less TRU than the reference $\mathrm{UO}_{2}$ 
reactor. Furthermore, whereas the TRU contained in $\mathrm{UO}_{2}$ spent fuel is essentially made up of $\mathrm{Pu}(87 \%)$, the TRU produced by the Th-U fuel is made up of about $60 \% \mathrm{~Np} 237$.

Compared with the reference $\mathrm{UO}_{2}$ reactor the Th-U reactors need between $50 \%$ and $\underline{95 \% \text { less natural } \mathrm{U}}$ depending on the water-to-fuel volume ratio. Unlike with light water, there is here a strong incentive to use a tight lattice when heavy water is the coolant since the amount of HEU that must be added decreases rapidly with the water-to-fuel volume ratio. The tight-pitch heavy-water-cooled reactors are very close to being self-sustained and the use of Thorium blankets outside or inside the core may produce enough $U$ to reach self-sustainability (see a first estimation given in Appendix E). These numbers are calculated considering $0 \% \mathrm{U}$ reprocessing losses. The impact of the reprocessing losses is treated in Chap. 8.

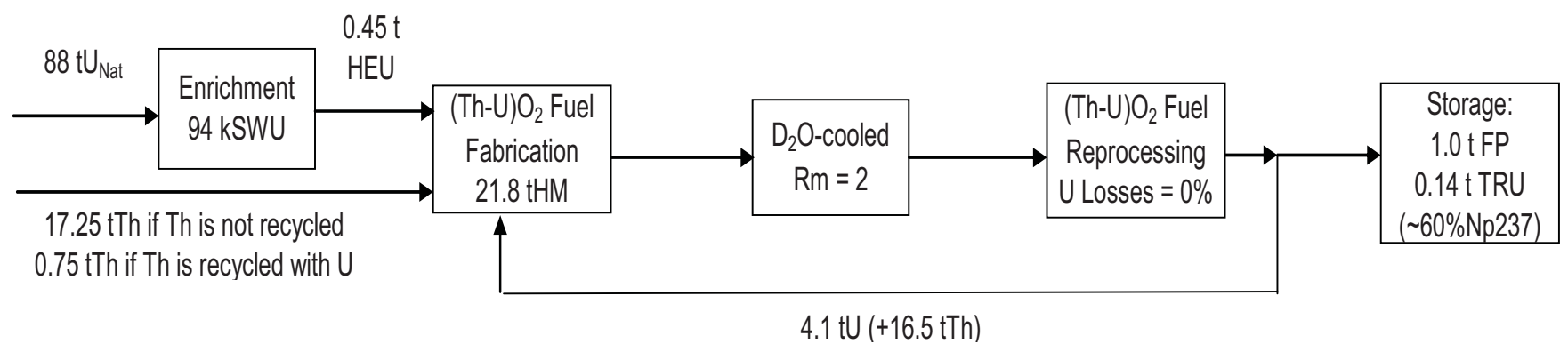

(a)

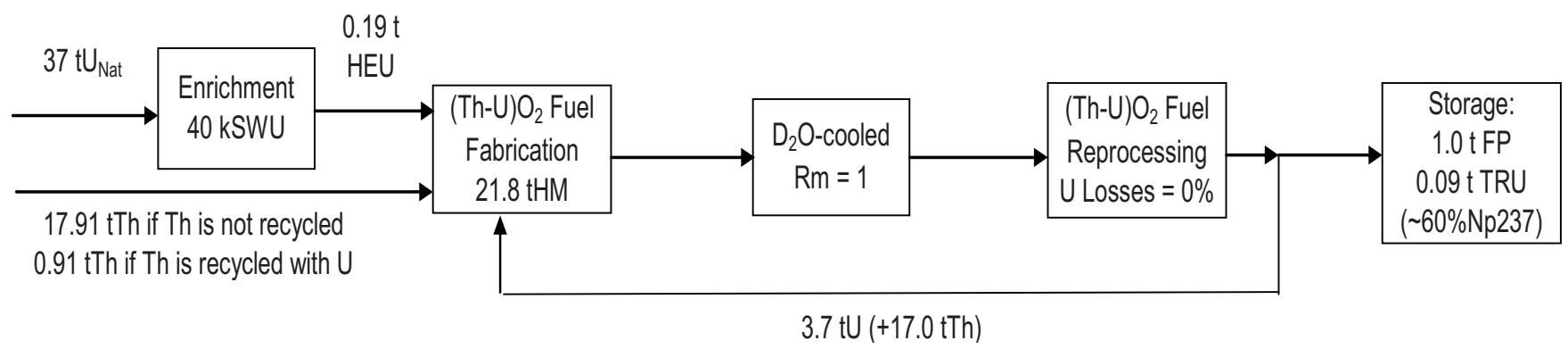

(b)

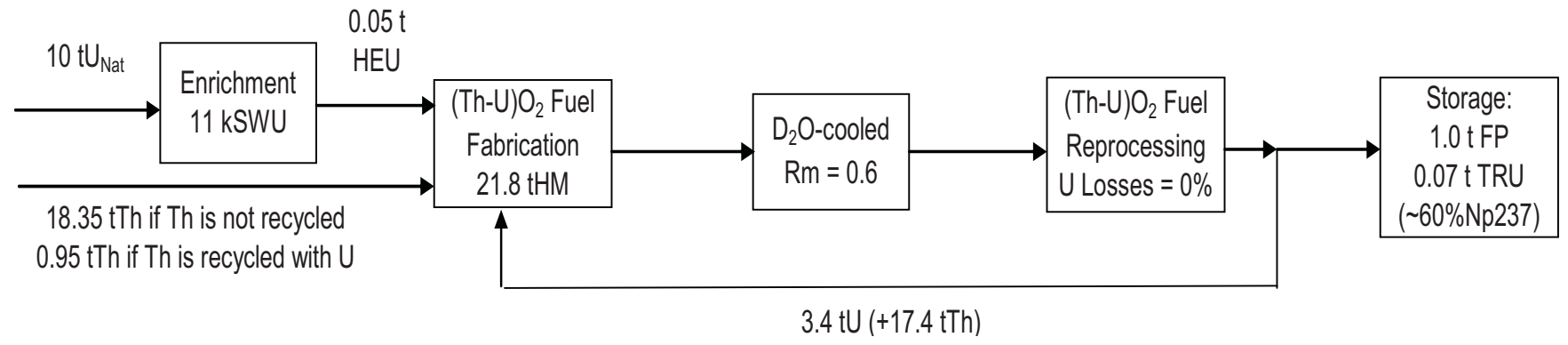

(c)

Figure 6.1.3. Static equilibrium annual mass flows for $1 \mathrm{GWe}$ heavy-water-cooled Thorium reactors with water-to-fuel volume ratio of 2 (a), 1 (b) and 0.6 (c). Burnup $=45,000 \mathrm{MWd} / \mathrm{t}_{\mathrm{HM}}$. Energy $=8 \mathrm{TWhe}$. 
It is interesting to note that the latest MIT report untitled "The Future of the Nuclear Fuel Cycle" [6.2] mentions the potential of advanced hard-spectrum LWRs as well:

"Historically it has been assumed that the pathway to a closed fuel cycle included recovery of plutonium from light water reactor spent nuclear fuel and use of that plutonium to start sodium-cooled fast reactors with high conversion ratios..... This future was based on two assumptions: (1) uranium resources are extremely limited and (2) a high conversion ratio is required to meet future needs. Our assessment is that both assumptions are false.

........ We must use the available time effectively if real options are to materialize in a few decades. This conclusion has important ramifications. For example, a future closed fuel cycle could be based on advanced hard-spectrum LWRs rather than the traditional fast-spectrum reactors, possibly with rather different costs and fuel forms........."

Impact of the specific power. To estimate the sensitivity of $m_{H E U}$ with regard to the specific power, the calculations related to the water-to-fuel volume ratio of 0.6 were rerun with the specific power corresponding to water-to-fuel volume ratio of 2, i.e. it was increased from $21 \mathrm{~kW} / \mathrm{th} / \mathrm{kg}_{\mathrm{HM}}$ to $37 \mathrm{~kW}_{\text {th }} / \mathrm{kg}_{\mathrm{HM}}$ (see Table 2.2). As mentioned earlier, the specific power impacts directly the neutron flux level, and this level impacts the necessary fissile loading as well as U233 build-up. Indeed, the higher the neutron flux, the higher the equilibrium level of Pa233 relative to that of U233; the ratio Pa233/U233 which is about 0.023 when the specific power is equal to $21 \mathrm{~kW}_{\mathrm{th}} / \mathrm{kg}_{\mathrm{HM}}$ increases to about 0.041 when the specific power is equal to $37 \mathrm{~kW}_{\text {th }} / \mathrm{kg}_{\mathrm{HM}}$.

Consequently the HEU enrichment for the first cycle increases by about $0.2 \%$ from $16.8 \%$ to $17 \%$. At each recycling, a little more HEU must be added and for the $10^{\text {th }}$ cycle instead of 0.05 ton, it is necessary to add 0.07 ton of HEU. These numbers show that, in this specific instance, the sensitivity of $m_{H E U}$ with regard to the specific power is not very important and that, consequently, it would be worthwhile to increase the specific power in order to minimize the initial investment in fissile material.

Impact of the neutron leakage. To estimate the sensitivity of $m_{H E U}$ with regard to the value considered for $k_{\infty}\left(\bar{B}_{E O C}\right)$ a few calculations were run considering $k_{\infty}\left(\bar{B}_{E O C}\right)=1.056$ instead of $k_{\infty}\left(\bar{B}_{E O C}\right)=1.0468$. Consequently the HEU enrichment for the first cycle increases by about $0.37 \%$ and $0.45 \%$ for the waterto-fuel volume ratios of 0.6 and 1 . Hence, the reactivity worth of HEU is, respectively, about 2500 $\mathrm{pcm} / \% \mathrm{HEU}$ and $2045 \mathrm{pcm} / \% \mathrm{HEU}$. At each recycling, more HEU must be added and for the $10^{\text {th }}$ cycle of the water-to-fuel volume ratio of 0.6 , instead of 0.05 ton, it is necessary to add 0.11 ton of $\mathrm{HEU}$. For the water-to-fuel volume ratio of 1 , instead of 0.19 ton, it is necessary to add 0.22 ton of HEU. 
These numbers show that the sensitivity of $m_{H E U}$ with regard to the neutron leakage is not negligible and that special care should be exercised to lower the neutron leakage (by staying away, if possible, from a "pancake" core design or by utilizing a steel reflector for example). $\underline{3-D}$ whole core calculations should be carried out to estimate the neutron leakaqe more precisely.

Impact of the HEU isotopic composition. The results presented so far are for an HEU enrichment of $90 \%$ and the results of some calculations carried out with an HEU' enrichment of $50 \%$ are presented in the Appendix B. To summarize, from the point of view of the natural $U$ utilization and of the amount TRU that needs to be disposed of, the Th-HEU' fuel (i.e. the 50-50 HEU) yields similar, though not quite as attractive, values than the Th-HEU fuel (i.e. the 90-10 HEU) only if the Pu is recycled together with the $U$. If the Pu produced in the Th-HEU' is not recycled, the natural $U$ utilization is much lower.

\subsection{Burnup $=60,000 \mathrm{MWd} / \mathrm{t}$}

Core physics aspects. The percentages of HEU for the first cycles are the same as for the 45,000 $\mathrm{MWd} / \mathrm{t}$ burnup which might seem surprising (17.6\% and $16.8 \%$ for, respectively, the water-to-fuel volume ratio of 1 and 0.6 ). The reason why the HEU enrichments are the same for 45,000 and $60,000 \mathrm{MWd} / \mathrm{t}$ is related to the fact that (1) the reactivity loss per cycle is small relative to the reactivity worth of HEU $(\sim+2500 \mathrm{pcm} / \% \mathrm{HEU})$ and (2) a little more $\mathrm{H}_{2} \mathrm{O}$ is necessary for the $60,000 \mathrm{MWd} / \mathrm{t}$ case than for the $45,000 \mathrm{MWd} / \mathrm{t}$ case in order to maintain a negative water temperature coefficient.

The reactivity losses per cycle (15,000 MWd/t) are between 1000 and $2000 \mathrm{pcm}$ for the water-to-fuel volume ratio of 1 and between 500 and $1500 \mathrm{pcm}$ for the water-to-fuel volume ratio of 0.6 . The water temperature coefficients are negative: between 0 and $-15 \mathrm{pcm} /{ }^{\circ} \mathrm{C}$ for both the water-to-fuel volume ratio of 1 and 0.6 .

Evolution of $U$ isotopic concentrations during recycling. Figures 6.2.1 (a \& b) show the evolution of the $U$ isotopic concentrations during recycling and for two water-to-fuel volume ratios ( 1 and 0.6$)$. The values obtained with $60,000 \mathrm{MWd} / \mathrm{t}$ are similar to those obtained with 45,000 MWd/t. The U235 spikes are noticeably higher since, logically, it requires more fissile material to reach $60,000 \mathrm{MWd} / \mathrm{t}$ than to reach 45,000 MWd/t.

The amount of TRU that needs to be disposed of increases from about $3 \mathrm{~kg} / \mathrm{tlHM}$ for the first recycling to about 4 to $5.5 \mathrm{~kg} / \mathrm{tlHM}$ for the $10^{\text {th }}$ recycling. The details of TRU production are given in the Appendix $\mathrm{C}$, Tables C.7 \& C.8. 


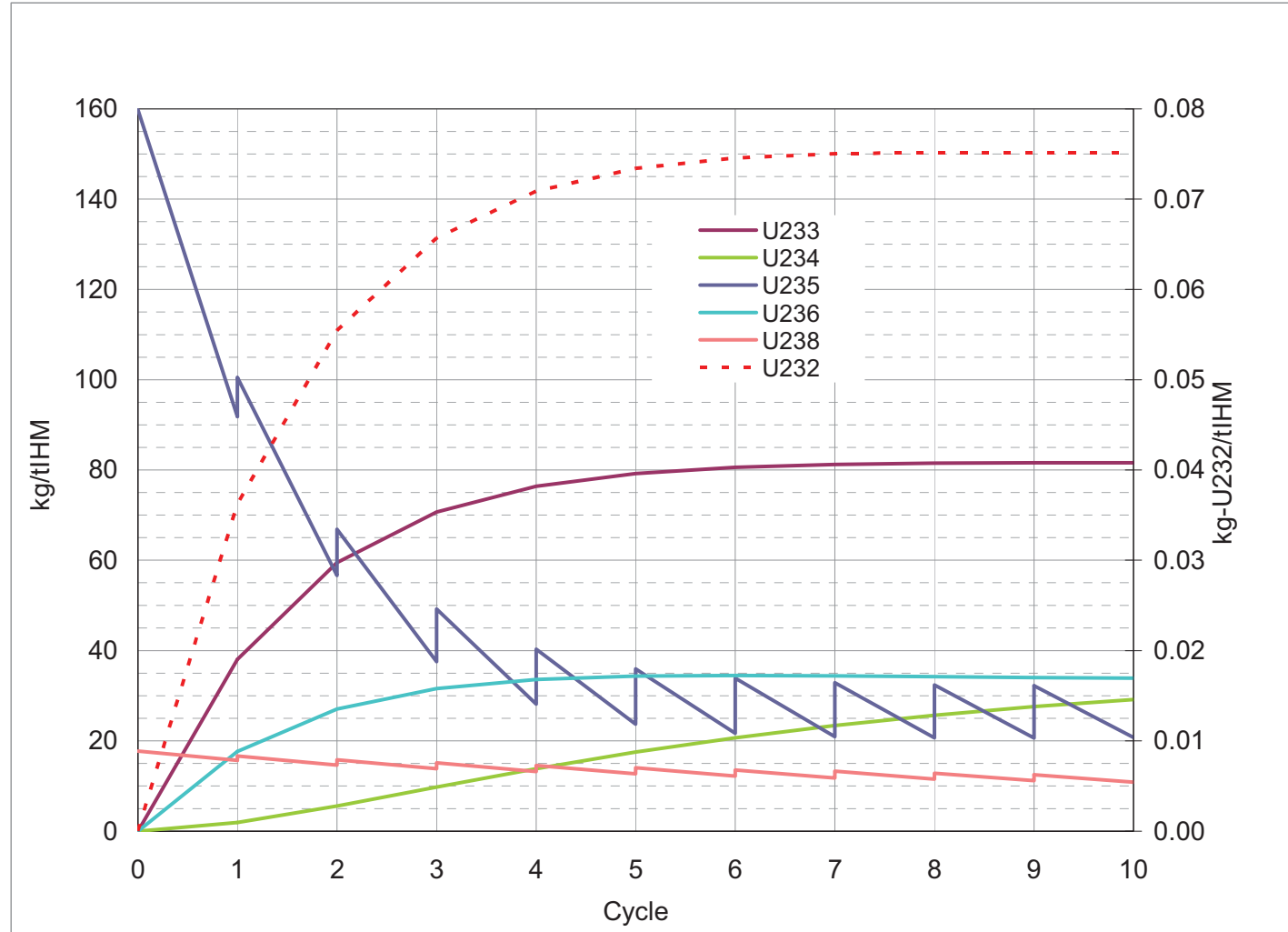

Figure 6.2.1a. Evolution of $U$ concentration at fabrication and reprocessing of the $T h-U$ fuel $(\mathrm{kg} / \mathrm{tlHM})$. Water-to-fuel volume ratio $=1$. Burnup $=60,000 \mathrm{MWd} / \mathrm{t}_{\mathrm{HM}}$. Heavy-water-cooled case.

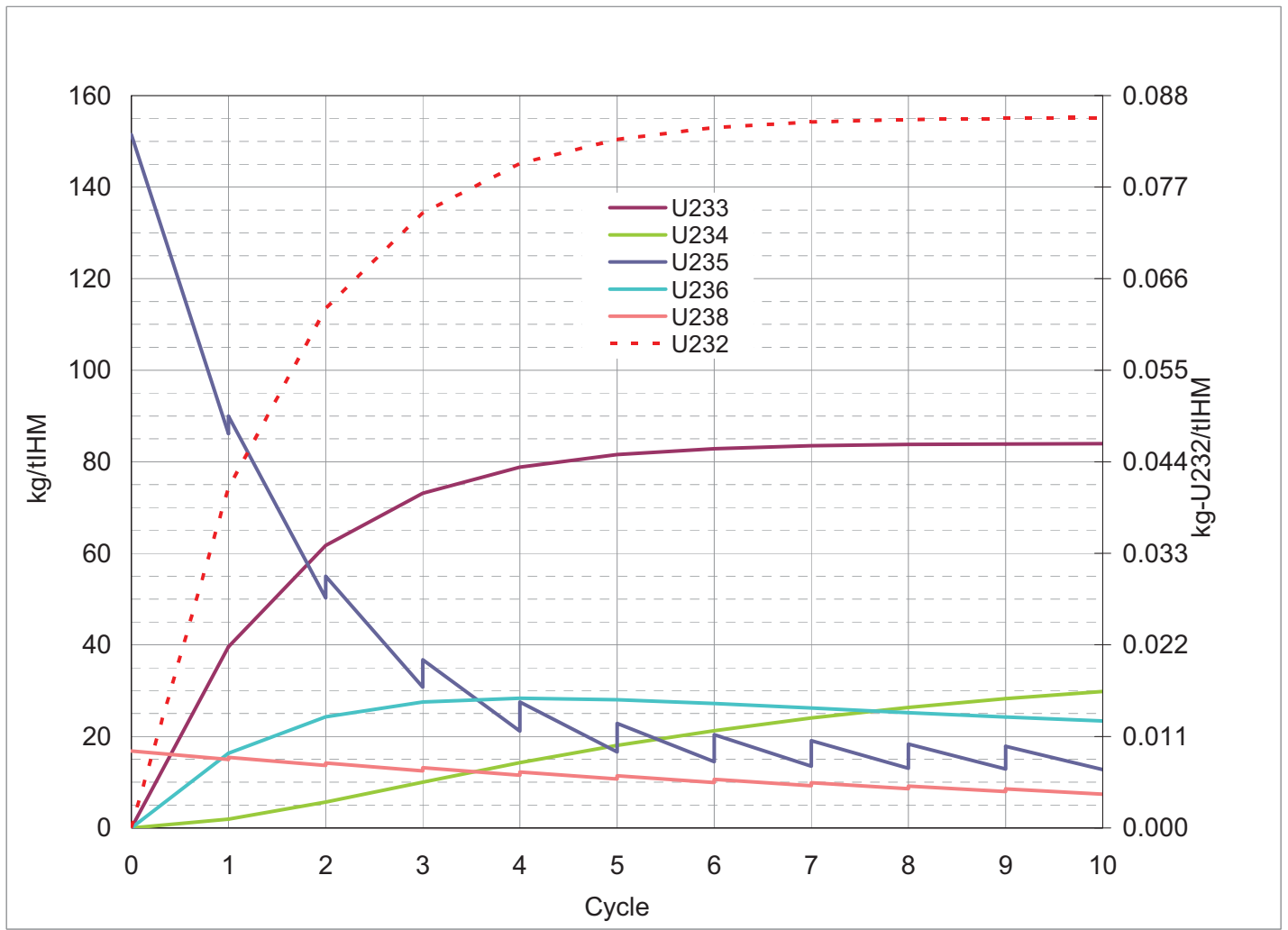

Figure 6.2.1b. Evolution of $U$ concentration at fabrication and reprocessing of the Th-U fuel (kg/tlHM). Water-to-fuel volume ratio $=0.6$. Burnup $=60,000 \mathrm{MWd} / \mathrm{t}_{\mathrm{HM}}$. Heavy-water-cooled case. 
Mass Flows. Figure 6.2 .2 below presents the annual mass flows for the $10^{\text {th }}$ cycle for a Th-U reactor characterized by a water-to-fuel volume ratio of 1 as well as for water-to-fuel volume ratio of 0.6 . The amount of $U$ reprocessed is reduced by about $25 \%$ compared with the $45,000 \mathrm{MWd} / \mathrm{t}$ cases. The TRU production is the same at $60,000 \mathrm{MWd} / \mathrm{t}$ as it was for $45,000 \mathrm{MWd} / \mathrm{t}$, i.e. these $\mathrm{Th}-\mathrm{U}$ fuels produce between 1.5 and 3.5 times less TRU than the reference $\mathrm{UO}_{2}$ reactor.

The Th- $U$ reactors need more natural $U$ when the burnup is $60,000 \mathrm{MWd} / \mathrm{t}$ than when it is $45,000 \mathrm{MWd} / \mathrm{t}$. The difference is, however, not very large: $4 \mathrm{tU}_{\mathrm{Nat}}$ per GWe.year (41 t $\mathrm{U}_{\mathrm{Nat}}$ instead of $\left.37 \mathrm{t} \mathrm{U}_{\mathrm{Nat}}\right)$ for the water-to-fuel volume ratio of 1 and $8 \mathrm{t} \mathrm{U}_{\mathrm{Nat}}$ per GWe.year (18 tU $\mathrm{U}_{\mathrm{Nat}}$ instead of $\left.10 \mathrm{tU} \mathrm{Nat}_{\mathrm{Nat}}\right)$ for the water-to-fuel volume ratio of 0.6 (remember that our reference $\mathrm{UO}_{2} \mathrm{PWR}$ necessitates $169 \mathrm{tU}_{\text {Nat }}$ per GWe.year). On the other hand, the amount of fuel to fabricate and reprocess every year decreases by $25 \%$ (i.e. from 21.8 tHM to $16.3 \mathrm{tHM}$ ) when the burnup increases from $45,000 \mathrm{MWd} / \mathrm{t}$ to $60,000 \mathrm{MWd} / \mathrm{t}$.

These numbers are calculated considering $0 \% \cup$ reprocessing losses. The impact of the reprocessing losses is treated in Chap. 8.

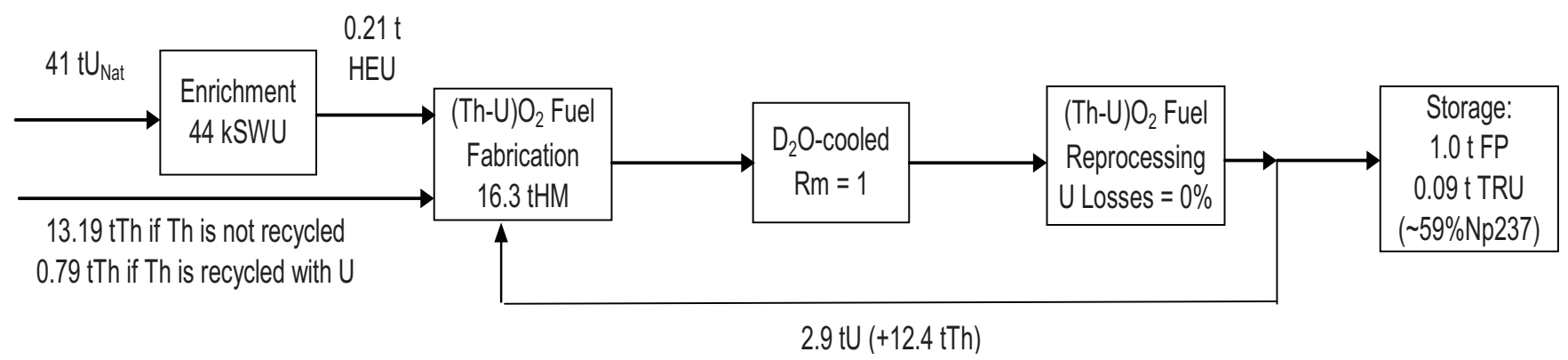

(a)

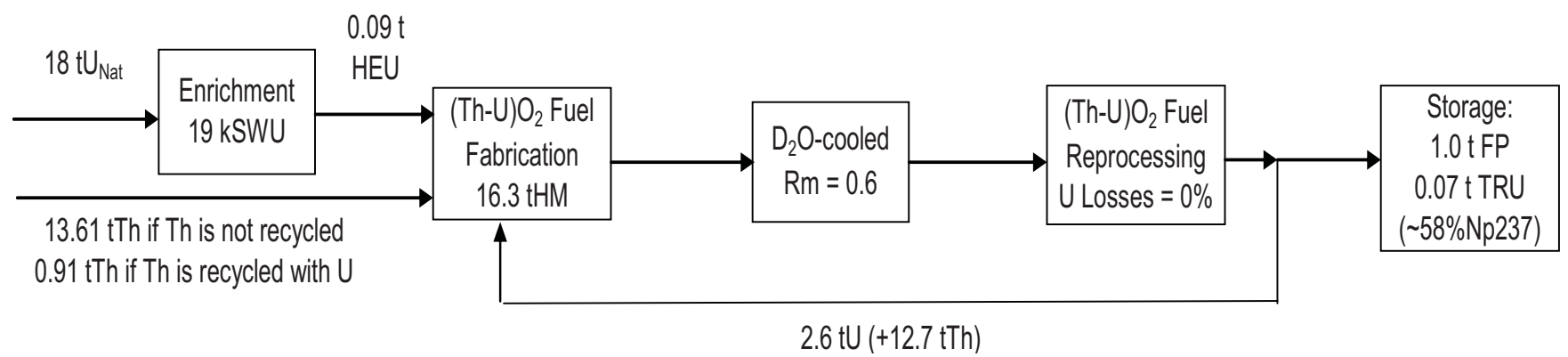

(b)

Figure 6.2.2. Static equilibrium annual mass flows for $1 \mathrm{GWe}$ heavy-water-cooled Thorium reactors with water-to-fuel volume ratio of 1 (a) and 0.6 (b). Burnup $=60,000 \mathrm{MWd} / \mathrm{t}_{\mathrm{HM}}$. Energy $=8 \mathrm{TWhe}$. 


\section{The heavy-water-cooled (Th-Pu-U) $\mathrm{O}_{2}$ reactors}

The objective here is to use $\mathrm{Pu}$ in the first core to limit the initial needs in HEU. However, if $\mathrm{Pu}$ alone is used as the fissile match for the first core, its content is such that the void coefficient might positive. Hence, in order to keep this important safety coefficient negative, the Pu content is set a $10 \%$ (see isotopic composition in Table 7.1) and the necessary complement of fissile material is provided by HEU. The actual amount of $\mathrm{Pu}$ that the core can accommodate while maintaining a negative void coefficient should be determined by more detailed 3-D calculations. At the end of each cycle, U\&Pu (\&Th) are recycled back into the reactor with the HEU topping necessary to reach the target burnup equal to 45,000 $\mathrm{MWd} / \mathrm{t}$ (Figure 7.1). Fresh Pu is used only in the first core.

Table 7.1. Pu isotopic composition (\%)

\begin{tabular}{|c|c|c|c|c|}
\hline Pu238 & Pu239 & Pu240 & Pu241 & Pu242 \\
\hline 2.60 & 54.3 & 25.9 & 9.58 & 7.62 \\
\hline
\end{tabular}

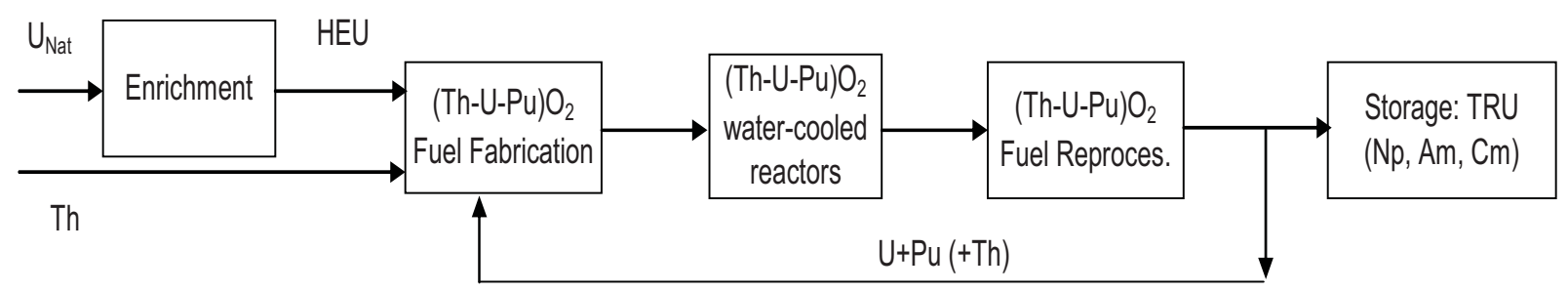

Figure 7.1. Th-U-Pu fuel cycle with HEU topping. Fresh Pu is used only in the first core.

The time between the end of the irradiation and the separation of the $U$ and Pu from the irradiated fuel (cooling time + reprocessing time) is 5 years and the time between the separation and the beginning of the next irradiation (fabrication and transportation times) is 1 year.

Core physics aspects. The percentages of HEU necessary to complement the $10 \% \mathrm{Pu}$ for the first cycles are not very dependant on the water-to-fuel volume ratio: $7.6 \%$ and $6.7 \%$ for volume ratios of, respectively 1 and 0.6 . A substantial amount of light water must be added to the heavy water in order to maintain a negative water temperature coefficients.

For the first cycle and for the water-to-fuel volume ratio of 1 , the water must be made up of about $27 \%$ $\mathrm{H}_{2} \mathrm{O}$ and $73 \% \mathrm{D}_{2} \mathrm{O}$. For the second cycle $8 \% \mathrm{H}_{2} \mathrm{O}$ is sufficient and this value decreases to zero after a few cycles. For the first cycle and for the water-to-fuel volume ratio of 0.6 , the water must be made up of about $37 \% \mathrm{H}_{2} \mathrm{O}$ and $63 \% \mathrm{D}_{2} \mathrm{O}$. For the second and third cycle, $15 \% \mathrm{H}_{2} \mathrm{O}$ and $11 \%$ are sufficient and this 
value decreases to about $4 \%$ after a few cycles. Depending on the recycling number the water temperature coefficient is between 0 and $-10 \mathrm{pcm} /{ }^{\circ} \mathrm{C}$. The reactivity losses per cycle $(15,000 \mathrm{MWd} / \mathrm{t})$ are between 1600 and $2300 \mathrm{pcm}$ for the volume ratio of 1 and between 900 and $1900 \mathrm{pcm}$ for the volume ratio of 0.6 .

Evolution of U\&Pu isotopic concentrations during recycling. Figures 7.2 and $\underline{7.3}$ show the evolution of the U\&Pu isotopic concentrations during recycling and for two water-to-fuel volume ratios (1 and 0.6). The U233 and U232 concentrations reach similar equilibrium values than those reached without $\mathrm{Pu}(80$ $\mathrm{kg} / \mathrm{tlHM}$ and $0.065 \mathrm{~kg} / \mathrm{tlHM})$.

The evolution of the Pu concentration is similar for both water-to-fuel volume ratios. Since there is no fresh Pu topping at the fabrication (HEU topping only), its concentration decreases rapidly from 100 $\mathrm{kg} / \mathrm{tlHM}$ down to 75,60 and $50 \mathrm{~kg} / \mathrm{tlHM}$ at the second, third and fourth recycling. At the $10^{\text {th }}$ recycling it reaches $18 \mathrm{~kg} / \mathrm{tIHM}$ and it is essentially made up of Pu240. This could be a way to get rid of the existing Pu present in the SNF ( $~ 800$ tons in the US) while at the same time producing U233 and transitioning to a Th-U fuel cycle. As the amount of $\mathrm{Pu}$ in the fuel decreases after each recycling, so does the amount of TRU that needs to be disposed of ( $6 \mathrm{~kg} / \mathrm{tIHM}$ and $3 \mathrm{~kg} / \mathrm{tlHM}$ for the first and $10^{\text {th }}$ recycling). The details of TRU production are given in the Appendix C, Tables C.9 \& C.10.

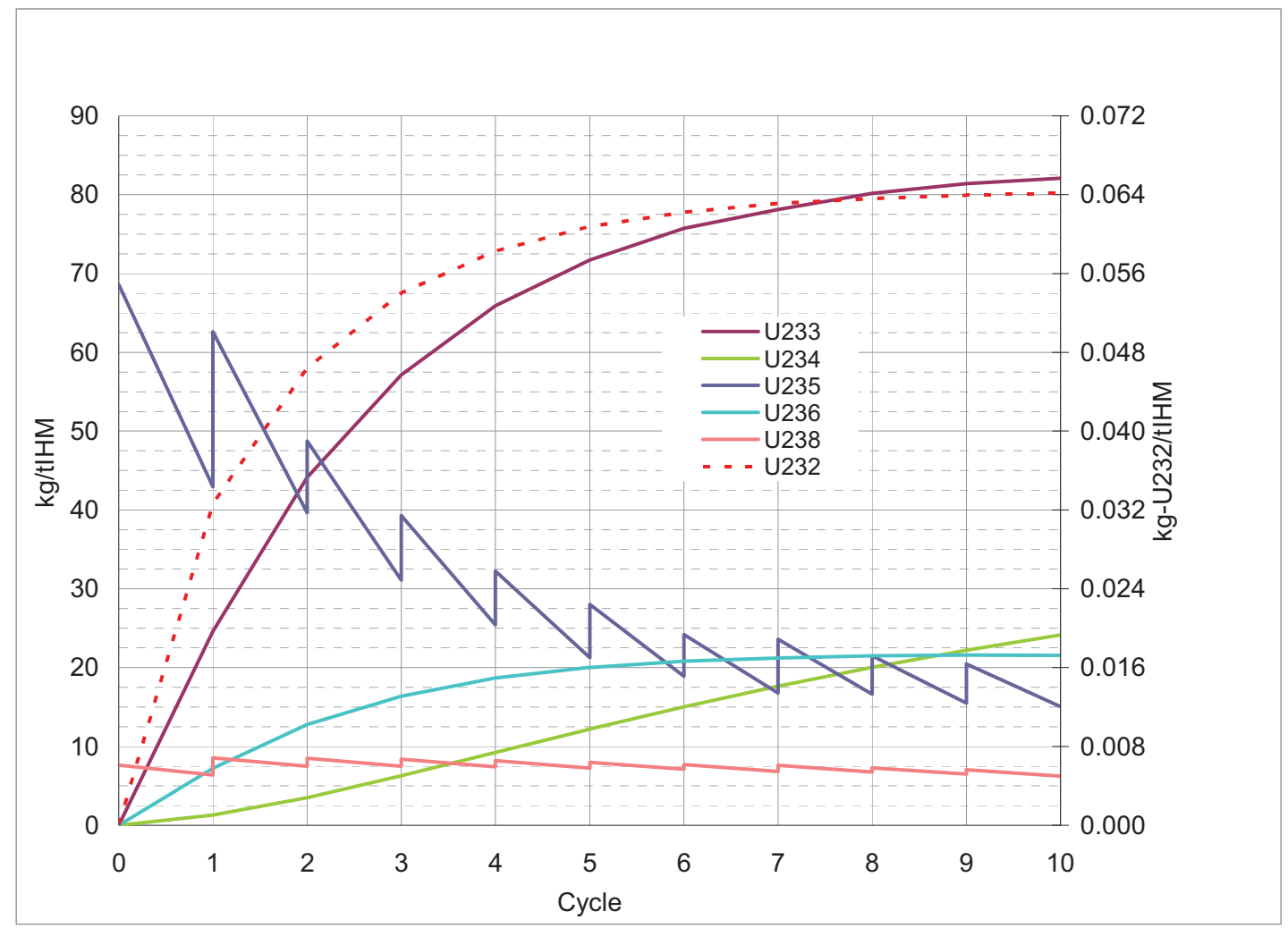

Figure 7.2a. Evolution of $U$ concentration at fabrication and reprocessing of the Th-U-Pu fuel (kg/tIHM). Water-to-fuel volume ratio $=1$. Burnup $=45 \mathrm{GWd} / \mathrm{t}_{\text {HM. }}$. Heavy-water-cooled case. 


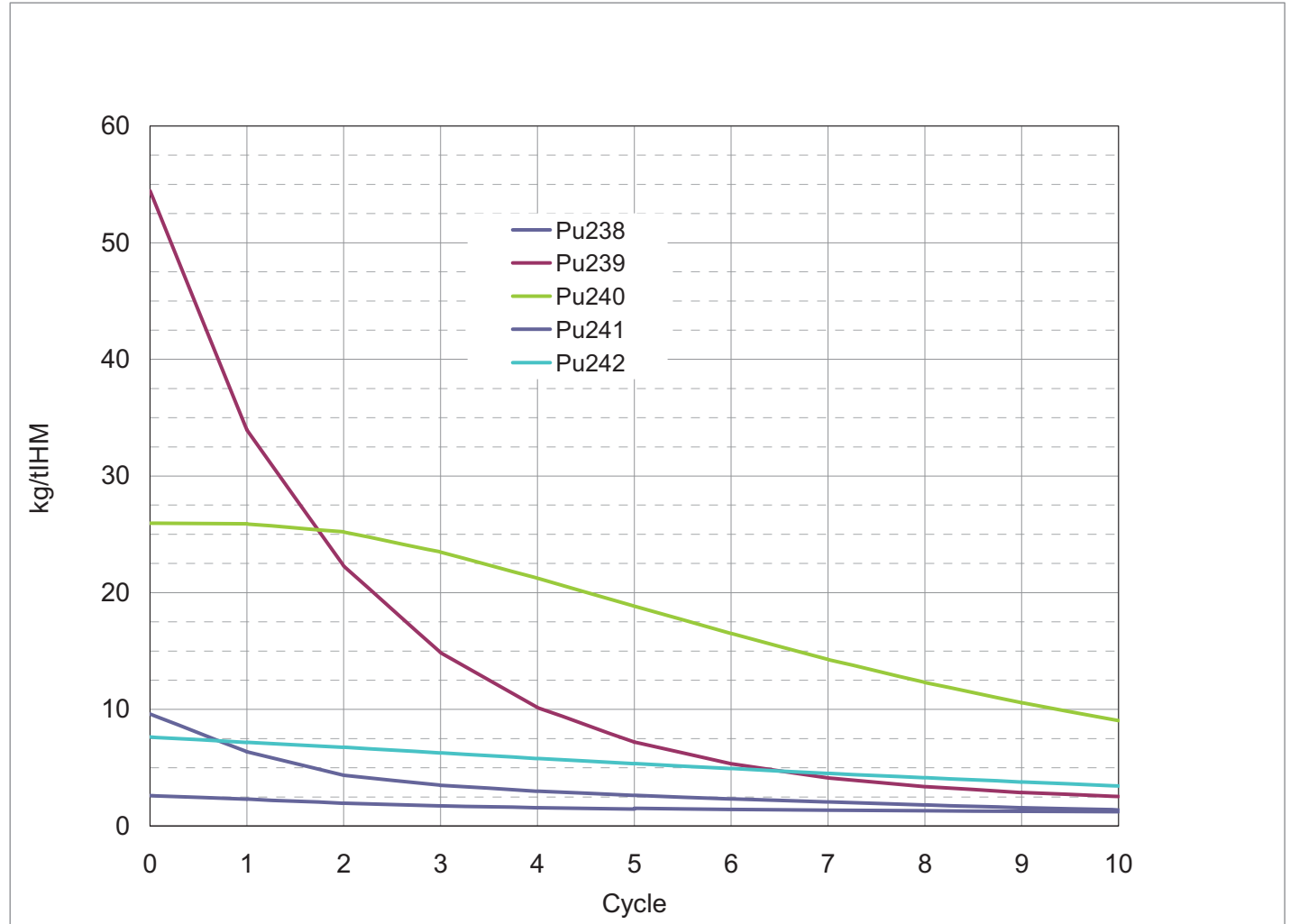

Figure 7.2b. Evolution of Pu concentration at fabrication and reprocessing of the Th-U-Pu fuel (kg/tlHM). Water-to-fuel volume ratio $=1$. Burnup $=45 \mathrm{GWd} / \mathrm{t}_{\mathrm{HM}}$. Heavy-water-cooled case.

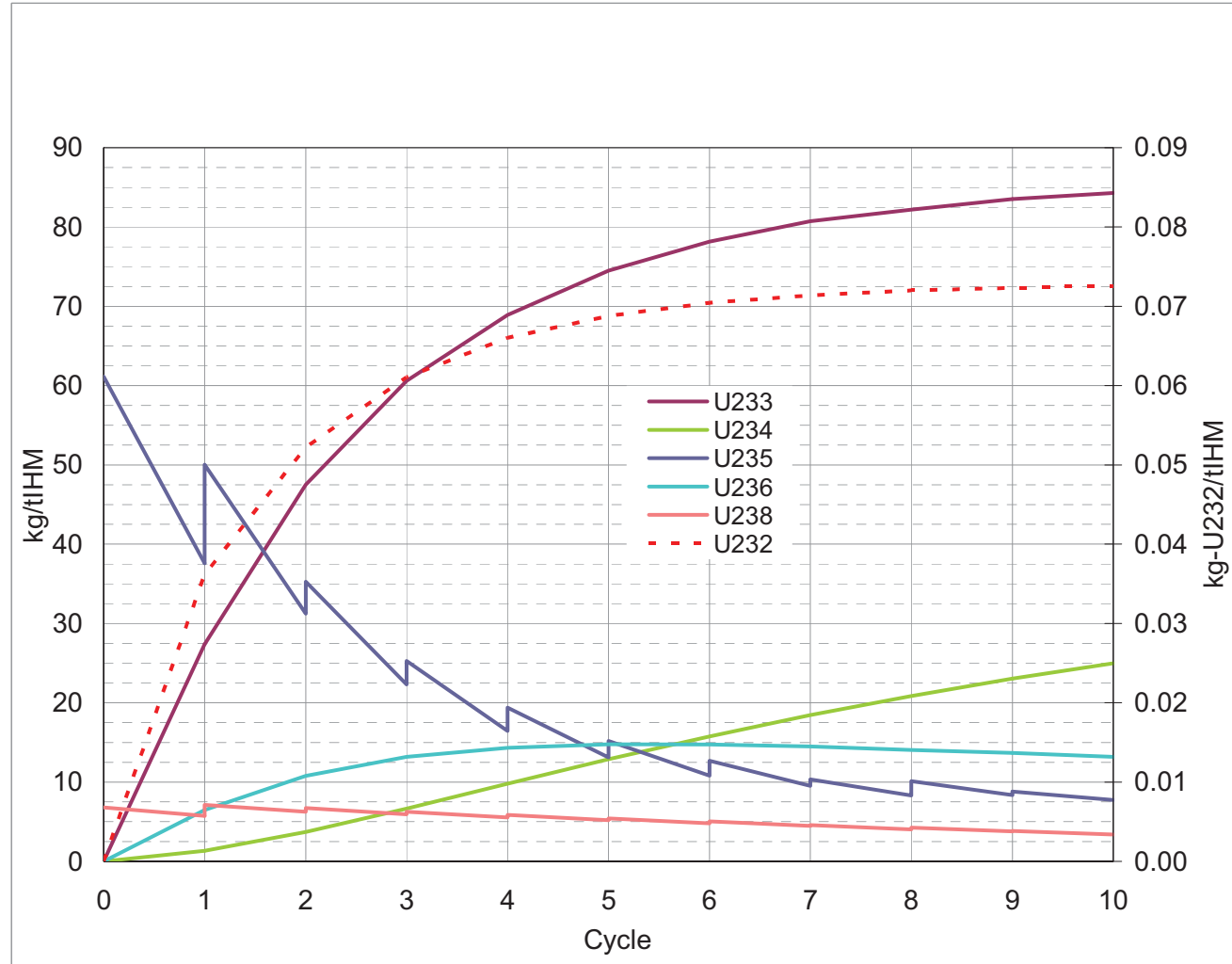

Figure 7.3a. Evolution of $U$ concentration at fabrication and reprocessing of the Th-U-Pu fuel $(\mathrm{kg} / \mathrm{tlHM})$. Water-to-fuel volume ratio $=0.6$. Burnup $=45 \mathrm{GWd} / \mathrm{t}_{\mathrm{HM}}$. Heavy-water-cooled case. 


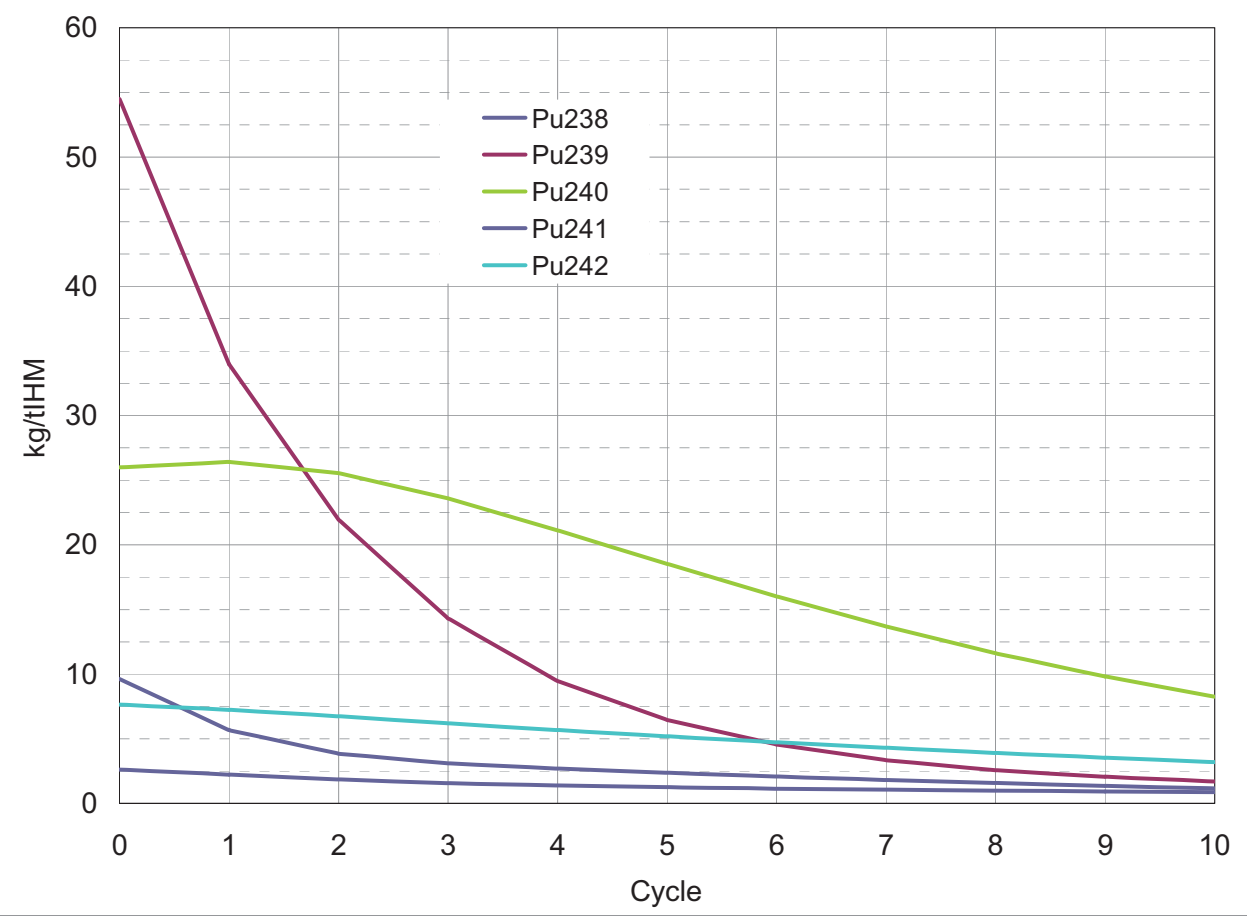

Figure 7.3b. Evolution of Pu concentration at fabrication and reprocessing of the Th-U-Pu fuel (kg/tlHM). Water-to-fuel volume ratio $=0.6$. Burnup $=45 \mathrm{GWd} / \mathrm{t}_{\text {Hм}}$. Heavy-water-cooled case.

The heat load associated to these TRU is presented in Appendix D (Figure D.5). It decreases with the recyclings as the amount of $\mathrm{Pu}$ in the fuel decreases and, consequently, as the amount of Am241 to be disposed of decreases. Indeed, for the first recycling the heat load from the TRU is higher than that from a $\mathrm{UO}_{2}$ spent fuel up to about 1000 years (by between $20 \%$ and $50 \%$ ) whereas for the $10^{\text {th }}$ recycling it is always lower (between 4 and 5 times lower for times after discharge comprised between 50 years and 10,000 years).

Mass Flows. Figure 7.4 below presents the annual mass flows for the $10^{\text {th }}$ cycle for a Th-U-Pu reactor characterized by water-to-fuel volume ratios of 1 and 0.6 . As before, the amount of U233 created is not sufficient to maintain a burnup of $45,000 \mathrm{MWd} / \mathrm{t}$ and consequently it is necessary to add HEU at each cycle.

The amount of $U$ and Pu reprocessed is about 3 tons and 0.35 ton per GWe.year. These Th-U-Pu fuels produce between 4 and 5 times less TRU than the reference $\mathrm{UO}_{2}$ reactor, mainly because Pu is recycled. Furthermore, whereas the TRU contained in $\mathrm{UO}_{2}$ spent fuel is essentially made up of $\mathrm{Pu}(87 \%)$, the TRU produced by the Th-U fuel is made up of about $50 \%-60 \% \mathrm{~Np} 237$. 
Compared with the reference $\mathrm{UO}_{2}$ reactor the Th-U-Pu reactors need between $85 \%$ and $99 \%$ less natural $\underline{U}$ depending on the water-to-fuel volume ratio. As mentioned earlier, the tight-pitch heavy-water-cooled reactors are very close to being self-sustained and the use of Thorium blankets outside or inside the core may produce enough $U$ to reach self-sustainability (see the first estimation given in Appendix E).

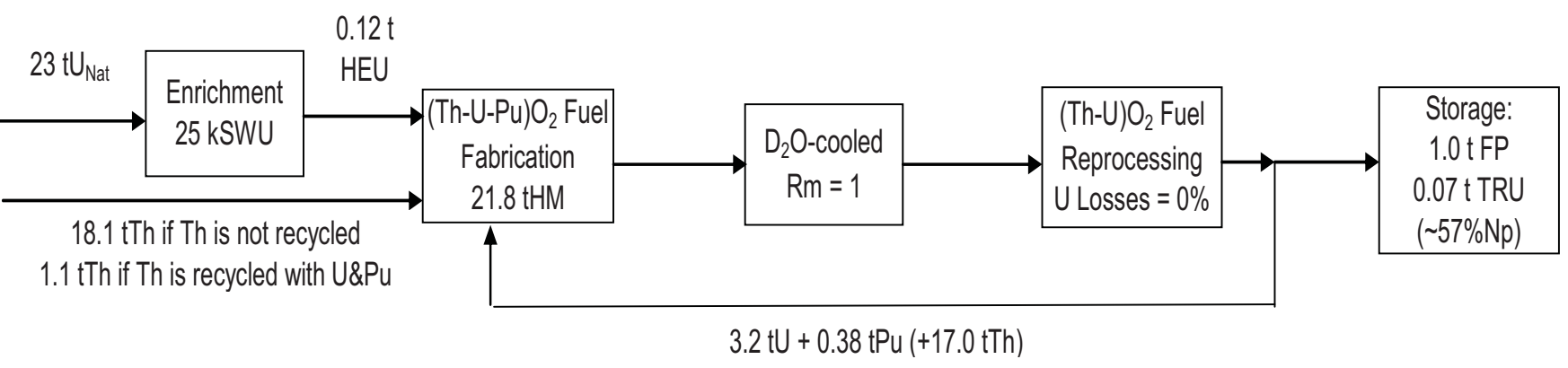

(a)

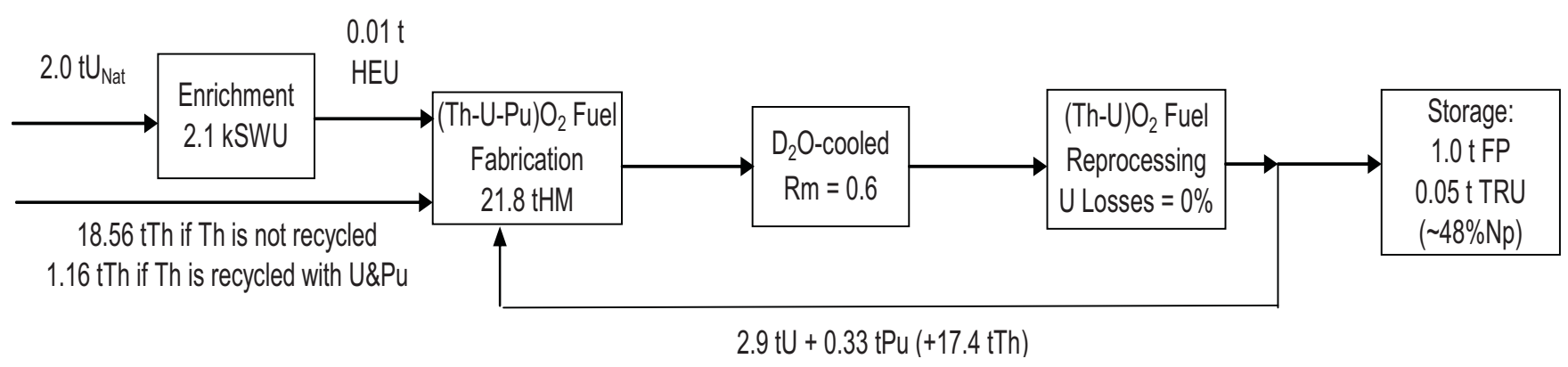

(b)

Figure 7.4. Static equilibrium annual mass flows for $1 \mathrm{GWe}$ heavy-water-cooled Thorium reactors with water-to-fuel volume ratios of 1 (a) and 0.6 (b). Burnup $=45,000 \mathrm{MWd} / \mathrm{t}_{\mathrm{HM}}$. Energy $=8 \mathrm{TWhe}$. 


\section{Taking the reprocessing losses into account}

The reprocessing losses impact the amount of HEU that it is necessary to add at the fabrication because the $U$ lost must be compensated for by adding more HEU at the fabrication. In order to investigate this effect, a few calculations were rerun considering that $2 \%$ of $U$ is lost at reprocessing, hence providing $\Delta m_{\text {HEU }}=m_{\text {HEU }}\left(L_{U}=2 \%\right)-m_{\text {HEU }}\left(L_{U}=0 \%\right)$. Knowing $\Delta m_{\text {HEU }}$, the $\Delta m_{U n a t}$ and $\Delta S W U$ can be approximated as $\Delta m_{\text {Unat }} \sim \Delta S W U \sim 200 \times \Delta m_{\text {HEU }}$ (see $\underline{\text { Table 2.1) }}$ ) therefore providing a useful "cost" feedback from the back-end to the front-end of the fuel cycle.

Since the amount of $U$ that is lost is a percentage of the amount of $U$ being reprocessed, the higher this amount the larger the $\Delta m_{\text {HEU }}$ will be for a given percentage of losses. The other factor impacting $\Delta m_{H E U}$ is the reactivity worth of HEU relative to that of the $U$ lost during reprocessing; if they are the same, $1 \mathrm{~kg}$ of $U$ lost at reprocessing must be replaced by $1 \mathrm{~kg}$ of HEU at the fabrication.

The light-water-cooled (Th-U) $\mathrm{O}_{2}$ reactors. The amount of HEU that it is necessary to add in order to reach a burnup of $45,000 \mathrm{MWd} / \mathrm{t}$ is not very dependant on the water-to-fuel volume ratio and is equal to about 0.50 ton/GWe.year when the $U$ reprocessing losses are equal to 0 (Figure 5.3). If we take into account $2 \%$ losses at reprocessing, this number increases by about $0.011,0.015$ and 0.03 ton/GWe.year for the water-to-fuel volume ratios of, respectively, 2, 1 and 0.6 .

Hence, compared with the values obtained with $0 \% \cup$ losses (i.e. 100 tons of natural $U$ per GWe.year and $\sim 100$ kSWU per GWe.year, see Figure 5.3), the $2 \% \cup$ losses at reprocessing would "cost" an extra 2 to 6 tons of natural U per GWe.year and 2 to $6 \mathrm{kSWU}$ per GWe.year for the light-water-cooled cases.

The heavy-water-cooled $(\mathrm{Th}-\mathrm{U}) \mathrm{O}_{2}$ reactors. The amount of HEU that it is necessary to add in order to reach a burnup of $45,000 \mathrm{MWd} / \mathrm{t}$ is about $0.45,0.19$ and 0.05 ton/GWe.year for the water-to-fuel volume ratios of, respectively, 2, 1 and 0.6 and when the $U$ reprocessing losses are equal to 0 (Figure 6.1.3). If we take into account $2 \%$ losses at reprocessing, these numbers increase by about 0.063 ton/GWe.year for the water-to-fuel volume ratio of 2 , and by about 0.072 ton/GWe.year for the water-to-fuel volume ratios of 1 and 0.6 .

For a burnup of $60,000 \mathrm{MWd} / \mathrm{t}$ the amount of HEU that it is necessary to add is about 0.21 and 0.09 ton/GWe.year for the water-to-fuel volume ratios of, respectively, 1 and 0.6 and when the $U$ reprocessing losses are equal to 0 (Figure 6.2.2). If we take into account $2 \%$ losses at reprocessing, these numbers increase by about 0.053 ton/GWe.year for both water-to-fuel volume ratios.

Hence, compared with the $0 \%$ losses cases, the $2 \%$ losses at reprocessing would "cost" an extra 11 to 14 tons of natural $U$ per GWe.year and 11 to $14 \mathrm{kSWU}$ per GWe.year for the heavy-water-cooled cases. 
The impact of the reprocessing losses on the natural $U$ and SWU needs for different water-to-fuel volume ratios and different burnups is summarized in the Table 8.1 below. As long as the losses are small, the effects can be considered, as a first approximation, linear, i.e. the effects observed between $0 \%$ and $2 \%$ losses will be the same as between $2 \%$ and $4 \%$ losses:

$$
\begin{gathered}
m_{\text {Unat }}\left(L_{U}=2 \%\right)-m_{U \text { nat }}\left(L_{U}=0 \%\right)=m_{U n a t}\left(L_{U}=4 \%\right)-m_{U n a t}\left(L_{U}=2 \%\right) \text { and } \\
S W U\left(L_{U}=2 \%\right)-S W U\left(L_{U}=0 \%\right)=S W U\left(L_{U}=4 \%\right)-S W U\left(L_{U}=2 \%\right)
\end{gathered}
$$

It is worthwhile noting that the sensitivities of the natural $U$ and SWU needs with regard to the reprocessing losses are higher for the $45,000 \mathrm{MWd} / \mathrm{t}$ cases than for the $60,000 \mathrm{MWd} / \mathrm{t}$ cases (the reason is that, since the burnup is lower, more fuel must be reprocessed per unit of energy and, as a result, it is more sensitive to the reprocessing losses). Consequently, the natural $U$ and SWU needs obtained for these two burnups are the same if the reprocessing losses are as high as $4 \%$. In this case, the 60,000 $\mathrm{MWd} / \mathrm{t}$ burnup should be the preferred option since the amount of fuel to fabricate and reprocess is $25 \%$ less than for the $45,000 \mathrm{MWd} / \mathrm{t}$ burnup.

Table 8.1. Impact of the $U$ reprocessing losses on the Natural Uranium and SWU needs for different water-to-fuel volume ratios and different burnups (calculated for the $10^{\text {th }}$ recycling).

\begin{tabular}{|c|c|c|c|c|}
\hline & $\begin{array}{c}\text { Burnup } \\
\text { (MWd/tIHM) }\end{array}$ & $\begin{array}{c}\text { U losses at } \\
\text { reprocessing }\end{array}$ & $\begin{array}{c}\text { Natural Uranium } \\
\text { (tons/GWe.y) }\end{array}$ & $10^{3}$ SWU/GWe.y \\
\hline Ref. UO2 & 51,000 & - & 169 & 124 \\
\hline H20-to-fuel vol. ratio = 2 & 45,000 & $0 \% \rightarrow 2 \% \rightarrow 4 \%$ & $100 \rightarrow 102 \rightarrow 104$ & $106 \rightarrow 108 \rightarrow 110$ \\
\hline D20-to-fuel vol. ratio = & 45,000 & $0 \% \rightarrow 2 \% \rightarrow 4 \%$ & $37 \rightarrow 51 \rightarrow 65$ & $40 \rightarrow 55 \rightarrow 70$ \\
\hline D20-to-fuel vol. ratio = 0.6 & 45,000 & $0 \% \rightarrow 2 \% \rightarrow 4 \%$ & $10 \rightarrow 24 \rightarrow 38$ & $11 \rightarrow 26 \rightarrow 41$ \\
\hline D20-to-fuel vol. ratio = 1 & 60,000 & $0 \% \rightarrow 2 \% \rightarrow 4 \%$ & $41 \rightarrow 51 \rightarrow 61$ & $44 \rightarrow 55 \rightarrow 66$ \\
\hline D20-to-fuel vol. ratio = 0.6 & 60,000 & $0 \% \rightarrow 2 \% \rightarrow 4 \%$ & $18 \rightarrow 28 \rightarrow 38$ & $19 \rightarrow 30 \rightarrow 41$ \\
\hline
\end{tabular}

These numbers do not take into account the use of internal or external $\mathrm{ThO}_{2}$ blankets which could potentially compensate for the inevitable losses at reprocessing (see Appendix E). 


\section{The heavy-water-cooled $(\mathrm{U}-\mathrm{Pu}) \mathrm{O}_{2}$ reactors}

The objective here is to compare the tight-pitch heavy-water-cooled (Th-Pu-U) $\mathrm{O}_{2}$ reactor of Chap. 7 with a tight-pitch heavy-water-cooled (U-Pu) $\mathrm{O}_{2}$ reactor (i.e. loaded with standard MOX fuel) from the point of view of natural $U$ utilization and TRU production. As before, the Pu content is set a $10 \%$ (see isotopic composition in Table 7.1) and the necessary complement of fissile material is provided by HEU. At the end of each cycle, U\&Pu are recycled back into the reactor with the HEU topping necessary to reach the target burnup equal to $45,000 \mathrm{MWd} / \mathrm{t}$ (Figure 9.1a). Fresh Pu is used only in the first core.

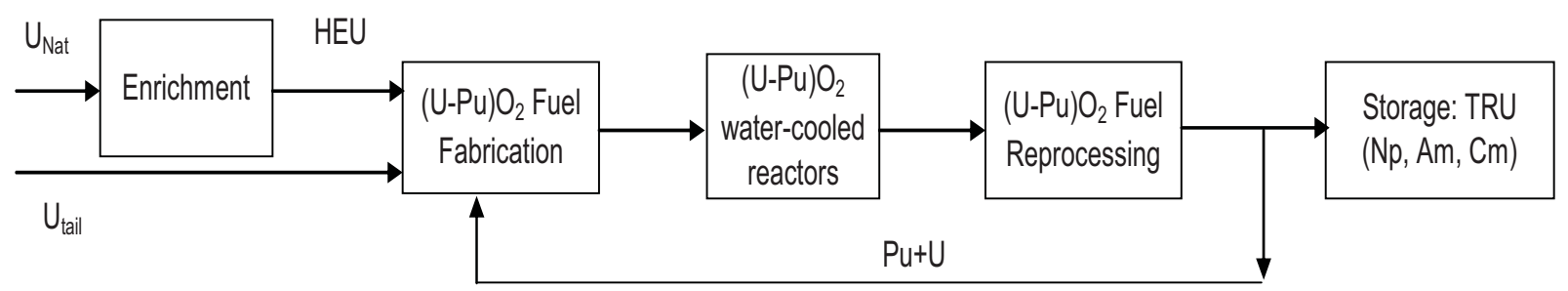

Figure 9.1a. U-Pu fuel cycle with $\underline{\mathrm{HEU}}$ topping. Fresh Pu is used only in the first core.

The use of HEU as schematized on Figure 9.1a has been simulated to be consistent with the approach of Chap. 7 for the (Th-Pu-U)O $\mathrm{O}_{2}$ reactor. If LEU is used instead of HEU (Figure 9.1b), the natural $U$ utilization will most likely be less because not all the reprocessed $U$ will be recycled. The difference in natural $U$ utilization will depend on the reactivity worth of the reprocessed U, i.e. on the amount of U235 and U236 in it.

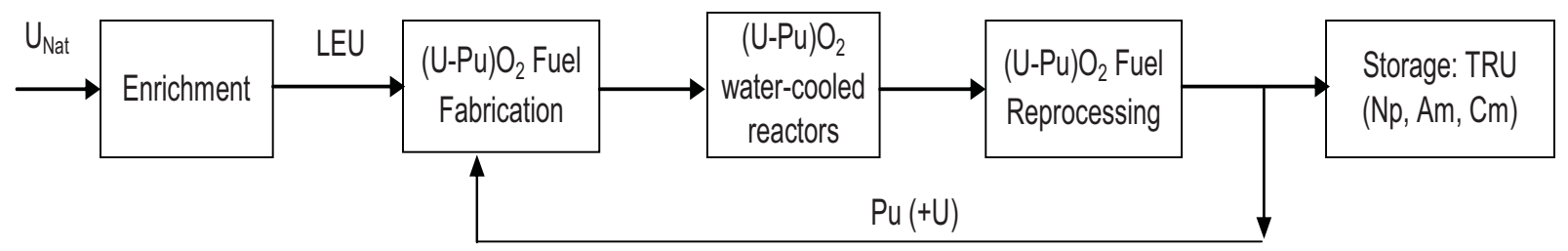

Figure 9.1b. U-Pu fuel cycle with LEU topping. Fresh Pu is used only in the first core.

As for the (Th-U-Pu) $\mathrm{O}_{2}$ case of Chap. 7, the time between the end of the irradiation and the separation of the $\mathrm{U}$ and $\mathrm{Pu}$ from the irradiated fuel (cooling time + reprocessing time) is 5 years and the time between the separation and the beginning of the next irradiation (fabrication and transportation times) is 1 year. 
Core physics aspects. The percentages of HEU necessary to complement the $10 \% \mathrm{Pu}$ for the first cycles are not very dependant on the water-to-fuel volume ratio: $5.5 \%$ and $4.0 \%$ for volume ratios of, respectively 1 and 0.6. An important difference between the Th-based fuel and the U-based fuel is related to the water temperature coefficient. We saw in Chap. 7 that a substantial amount of $\mathrm{H}_{2} \mathrm{O}$ had to be added to the $\mathrm{D}_{2} \mathrm{O}$ in order to maintain a negative water temperature coefficients for the first cycle of the Th-based fuel.

With the U-based fuel whatever the percentage of $\mathrm{H}_{2} \mathrm{O}$, the water temperature coefficient remains positive for the water-to-fuel volume ratio of 0.6 . For the water-to-fuel volume ratio of 1 , more than $50 \%$ of $\mathrm{H}_{2} \mathrm{O}$ is necessary to maintain the water temperature coefficient negative.

In order to maximize the $\mathrm{U} \rightarrow \mathrm{Pu}$ conversion, it was however decided to pursue the calculations with $100 \%$ heavy water to compare with the results presented in Chap. 7 for the Th-based fuel. Depending on the recycling number the water temperature coefficient is between +15 and $+30 \mathrm{pcm} /{ }^{\circ} \mathrm{C}$. The reactivity losses per cycle $(15,000 \mathrm{MWd} / \mathrm{t})$ are between 2500 and $3600 \mathrm{pcm}$ for the volume ratio of 1 and between 1200 and $2500 \mathrm{pcm}$ for the volume ratio of 0.6 .

The calculations carried out for voided lattices show that the $k_{\infty}$ of the U-Pu lattices are about 10,000 pcm higher than that of the Th-U-Pu lattices. Indeed, for the average beginning of cycle burnup, i.e. 15,000 MWd/t, it is about 1.2 for the voided U-Pu lattices (95\% voided) and about 1.1 for the voided Th-U-Pu lattices. Even though the evolution of the reactivity during a loss-of-coolant accident (LOCA) necessitates more detailed 3-D calculations, especially to determine whether the voided core is critical or not, the values of $k_{\infty}$ obtained for the voided lattices indicate that, for the same geometrical configuration, the reactivity of the voided U-Pu core will be higher than that of the Th-U-Pu. The implication in terms of core design is that the U-Pu core will probably need to be shorter than the Th-U-Pu core to ensure that it is subcritical when voided and, consequently, for a given diameter of the vessel, less power will be available.

NB: To minimize the pressure drop and pumping power in the tight-pitch cores, it may be necessary to shorten the core compared to the $350-400 \mathrm{~cm}$ of actual PWRs. To determine whether the pressure drop issues or the void coefficient issues will dictate the height of the core will necessitate more detailed studies.

Evolution of U\&Pu isotopic concentrations during recycling. Figures 9.2 and $\underline{9.3}$ show the evolution of the U\&Pu isotopic concentrations during recycling and for two water-to-fuel volume ratios (1 and 0.6 ). Obviously, the evolution of the Pu concentration is very different from that obtained with the Th-based fuel. Whereas it decreases rapidly in the Th-based fuel, here it increases from $100 \mathrm{~kg} / \mathrm{tl} \mathrm{HM}$ at the first 
cycle up to $160-170 \mathrm{~kg} / \mathrm{tIHM}$ at the $10^{\text {th }}$ cycle (it was about $20 \mathrm{~kg} / \mathrm{tIHM}$ in the $10^{\text {th }}$ cycle of the Th-based fuel). Surprisingly enough, the concentrations of U233 in the Th-based fuel and that of Pu239 in the Ubased fuel saturate at a similar level, i.e. between 80 and $90 \mathrm{~kg} / \mathrm{tl} \mathrm{HM}$.

About 10 to $15 \mathrm{~kg}-\mathrm{U} 235 / \mathrm{tIHM}$ must be added at each fuel fabrication for the water-to-fuel volume ratio of 1. For the water-to-fuel volume ratio of 0.6 and after about 5-6 recyclings it is not necessary to add U235 any more, i.e. the reprocessed Pu brings enough reactivity to reach 45,000 MWd/t.

The amount of TRU that needs to be disposed of is comprised between about 5 and $6 \mathrm{~kg} / \mathrm{tlHM}$. The details of TRU production are given in the Appendix C, Tables C.11 \& C.12.

The heat load associated to these TRU is presented in Appendix D (Figure D.6). At the first recycling the heat load from the TRU that needs to be disposed of is similar to that obtained with the Th-U-Pu fuel of Chapter 7 , i.e. it is higher than that from a $\mathrm{UO}_{2}$ spent fuel up to about 1000 years (by between $20 \%$ and $50 \%$ ). However unlike for the Th-U-Pu fuel of Chapter 7 , the heat load does not decrease as the recyclings go on because the amount of Am241 that needs to be disposed of at each recycling is about constant $(3.5 \mathrm{~kg} / \mathrm{tlHM})$.

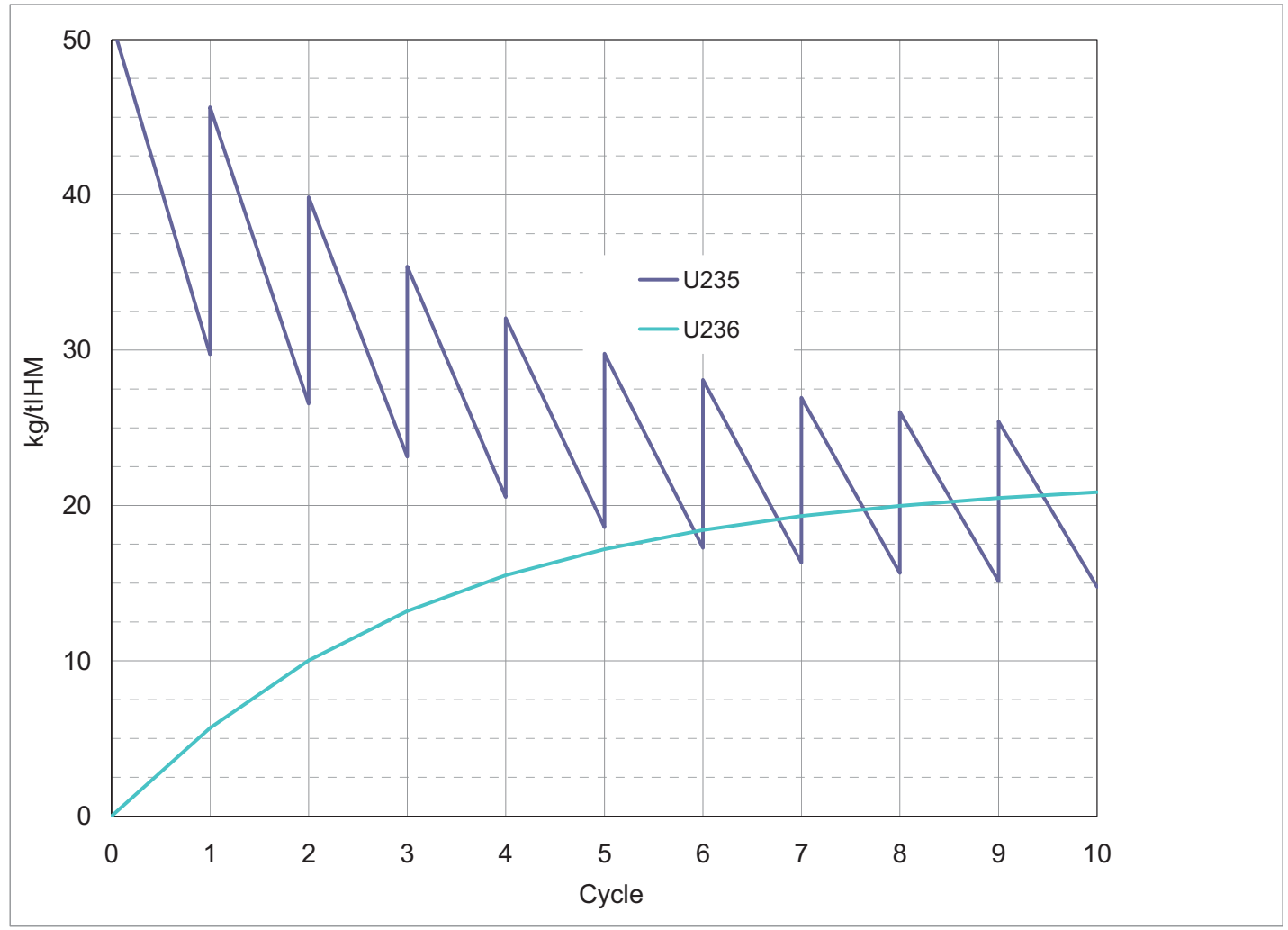

Figure 9.2a. Evolution of $U$ concentration at fabrication and reprocessing of the $U-P u$ fuel $(\mathrm{kg} / \mathrm{tlHM})$. Water-to-fuel volume ratio $=1$. Burnup $=45 \mathrm{GWd} / \mathrm{t}_{\mathrm{HM}}$. Heavy-water-cooled case. 


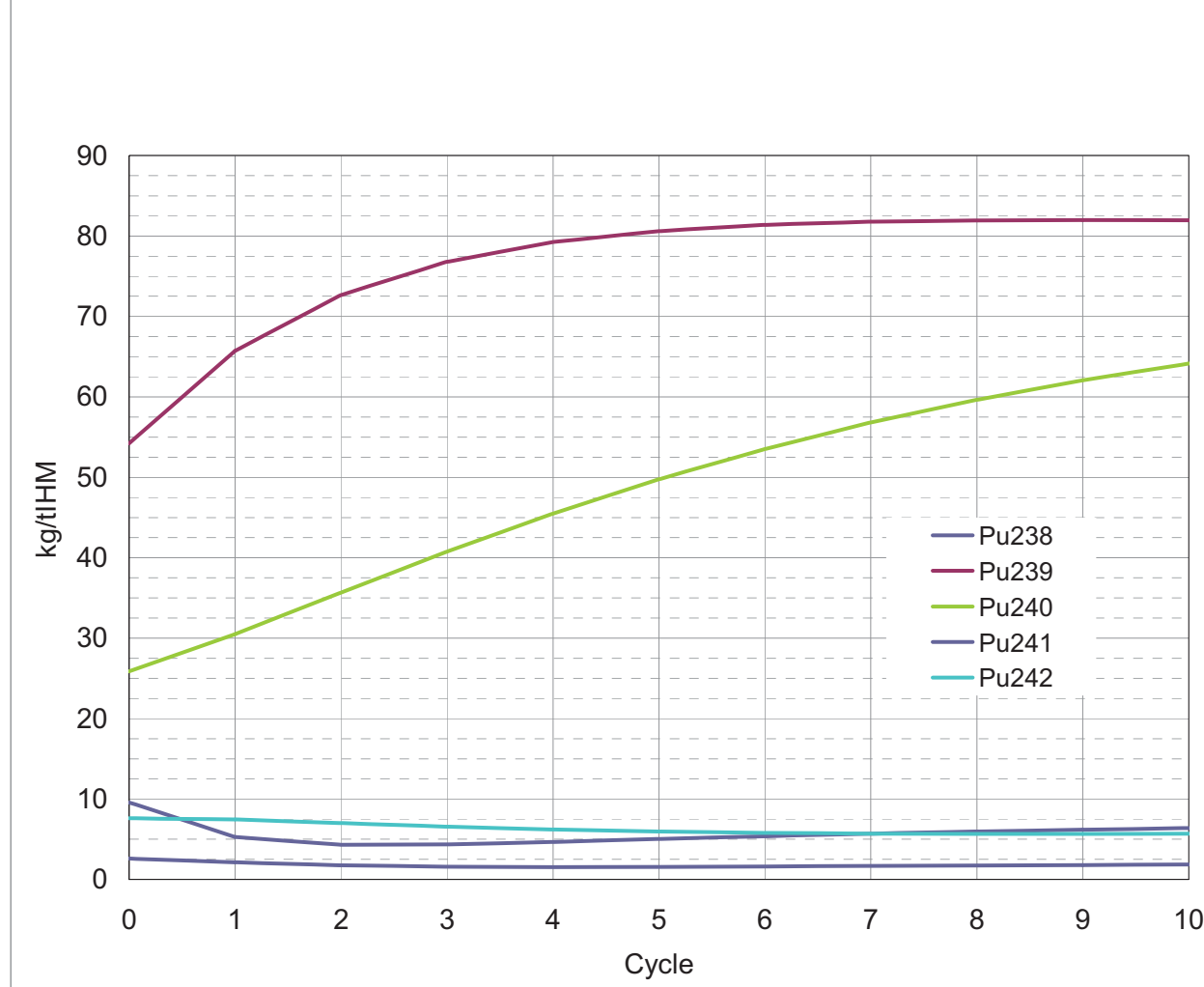

Figure 9.2b. Evolution of Pu concentration at fabrication and reprocessing of the U-Pu fuel (kg/tlHM). Water-to-fuel volume ratio $=1$. Burnup $=45 \mathrm{GWd} / \mathrm{t}_{\text {HM }}$. Heavy-water-cooled case.

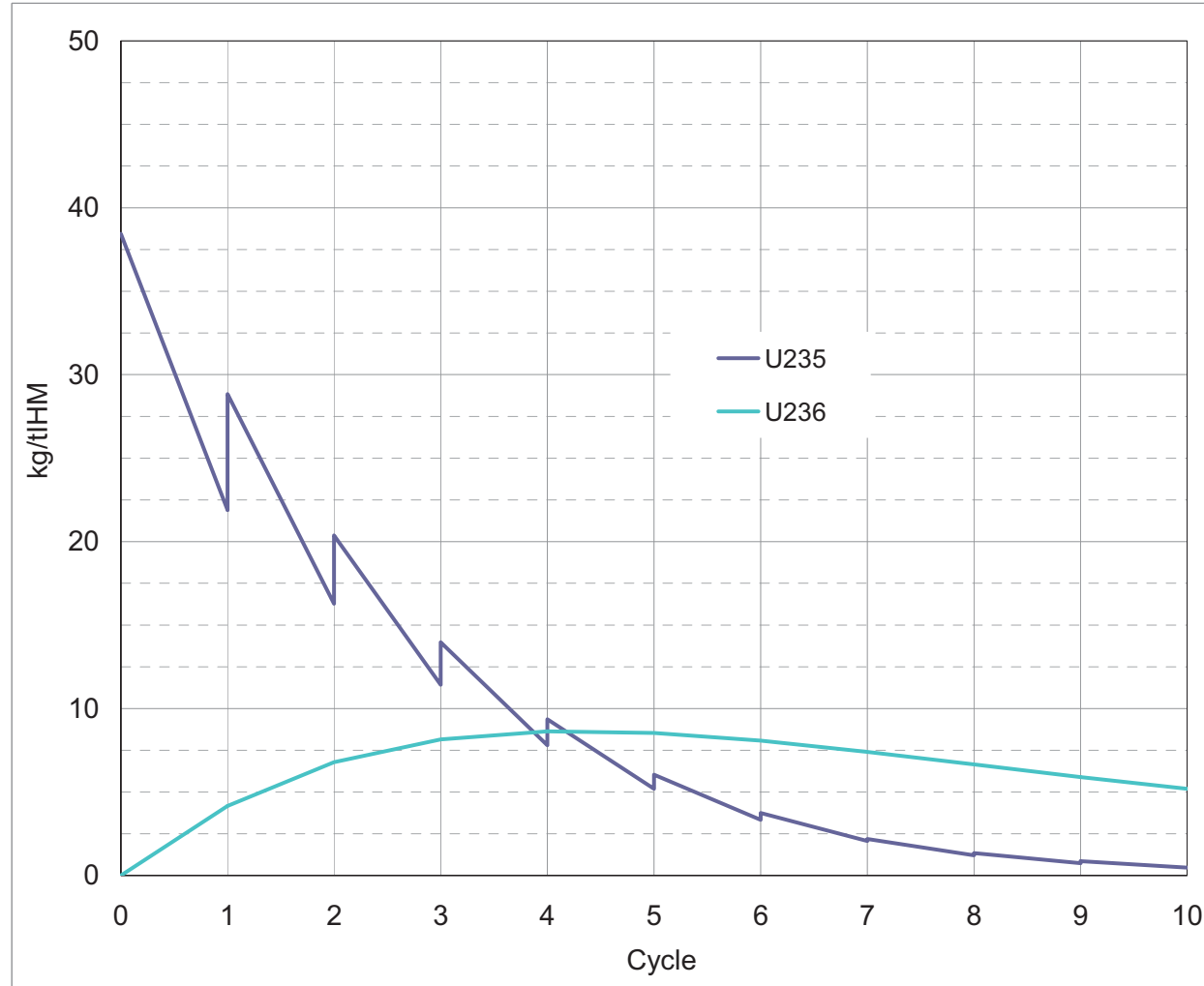

Figure 9.3a. Evolution of $U$ concentration at fabrication and reprocessing of the U-Pu fuel (kg/tIHM). Water-to-fuel volume ratio $=0.6$. Burnup $=45 \mathrm{GWd} / \mathrm{t}_{\text {HM }}$. Heavy-water-cooled case . 


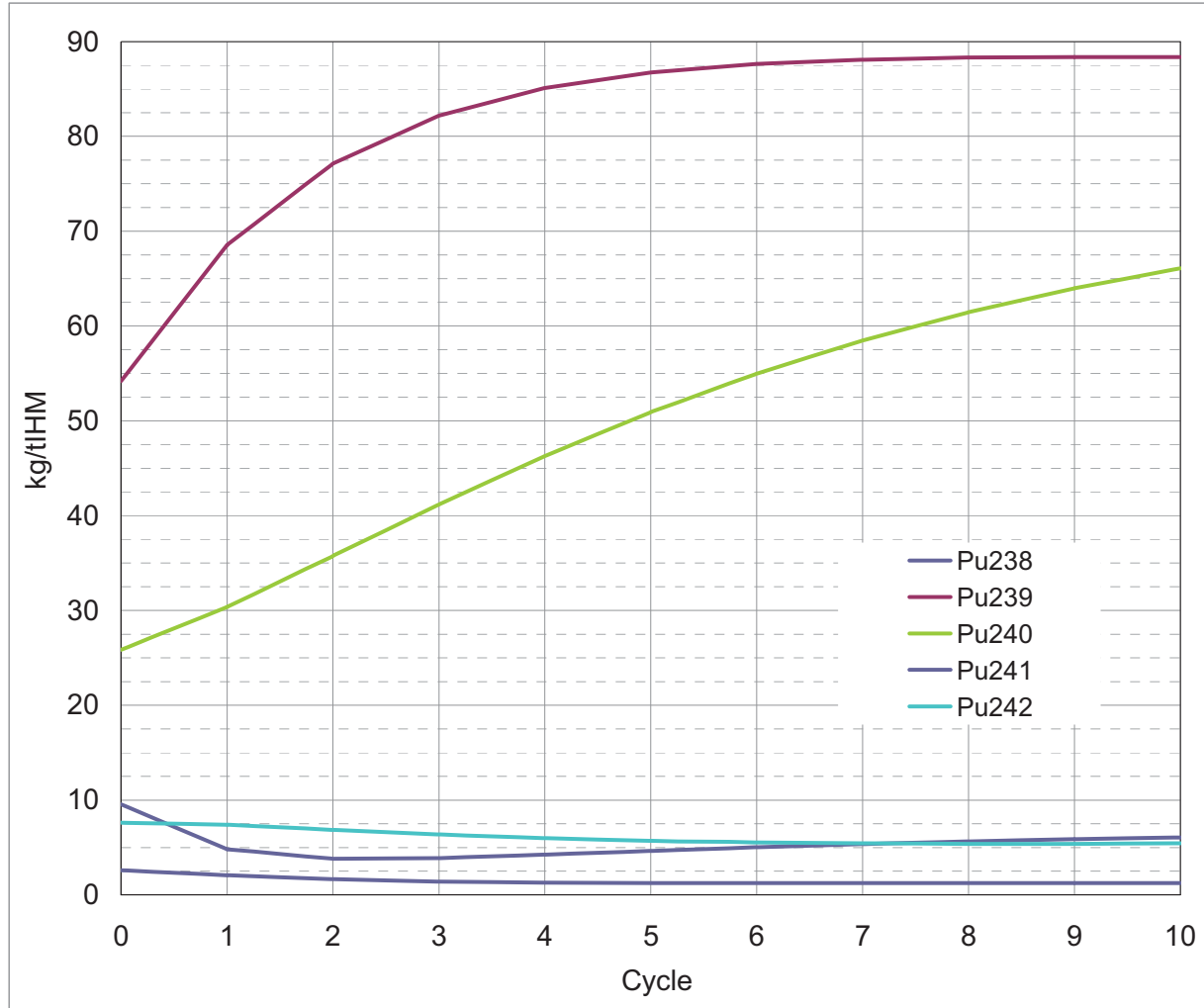

Figure 9.3b. Evolution of Pu concentration at fabrication and reprocessing of the U-Pu fuel (kg/tlHM). Water-to-fuel volume ratio $=0.6$. Burnup $=45 \mathrm{GWd} / \mathrm{t}_{\mathrm{HM}}$. Heavy-water-cooled case.

Mass Flows. Figure 9.4 below presents the annual mass flows for the $10^{\text {th }}$ cycle for a U-Pu reactor characterized by water-to-fuel volume ratios of 1 and 0.6 .

The amount of Pu reprocessed is about 3.5 tons per GWe.year, i.e. similar to the amount of $\mathrm{U}$ and $\mathrm{Pu}$ reprocessed in the Th-U-Pu cases (about 3 tons of $U$ and 0.35 ton of Pu per GWe.year). The amount of TRU produced in these U-Pu fuels is about twice that produced in the Th-U-Pu fuels. Furthermore, whereas the TRU produced by the Th-U-Pu fuel is made up of about $50 \%-60 \%$ Neptunium, the TRU produced by the U-Pu fuel is made up of about $60 \%-80 \%$ Americium.

The U-Pu fuel needs about 26 tons of natural U more per GWe.year than the Th-U-Pu fuel when the heavy-water-to fuel volume ratio is 1 (i.e. about twice as much). For the heavy-water-to-fuel volume ratio of 0.6 , the natural $U$ needs are similar (the U-Pu needs about 2 tons less than the Th-U-Pu case).

It must be kept in mind that these mass flows are obtained with heavy-water-cooled $(\mathrm{U}-\mathrm{Pu}) \mathrm{O}_{2}$ cores and that these cores have unacceptable intrinsic characteristics: positive water temperature coefficient and potentially positive reactivity under LOCA for large $3000 \mathrm{MWth}$ cores (i.e. $\sim 30 \mathrm{~m}^{3}$ cores). If light water and heavy water are mixed to render these characteristics more acceptable the natural $U$ utilization will 
be lower and consequently the amount of natural $U$ necessary to run these (U-Pu) reactors will increase. The U-Pu fuel cycle is intrinsically more sensitive to the neutron spectrum (and consequently to the characteristics of the coolant) than the Th-U fuel cycle because of the behavior of the Pu239 and U233 cross-sections as a function of the neutron energy. Indeed, the number of neutrons released per neutron absorbed (Figure 9.5) increases faster for Pu239 than for U233 between about $1 \mathrm{keV}$ and $1 \mathrm{MeV}$ which makes it more sensitive to the neutron spectrum; the faster the neutrons the higher the conversion ratio of U-Pu fuels.

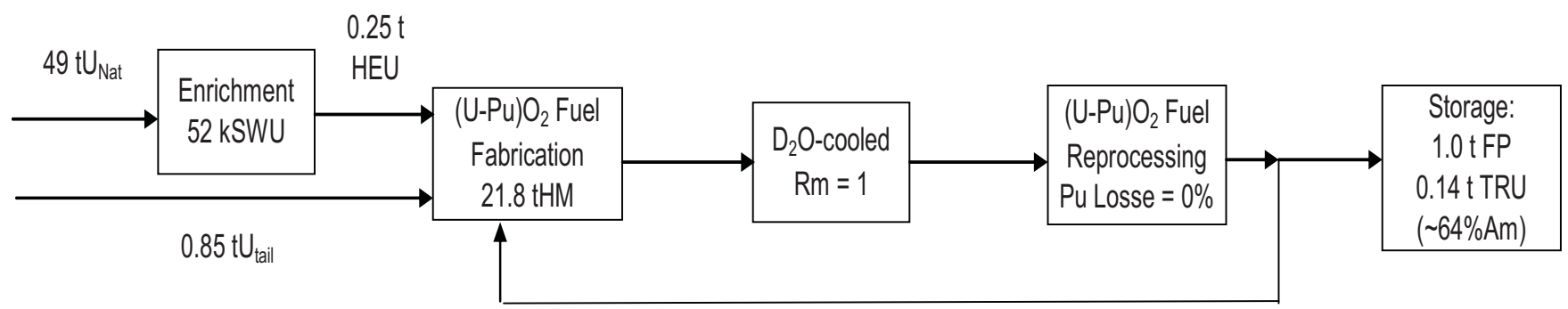

$17.2 \mathrm{tU}+3.5 \mathrm{tPu}$

(a)

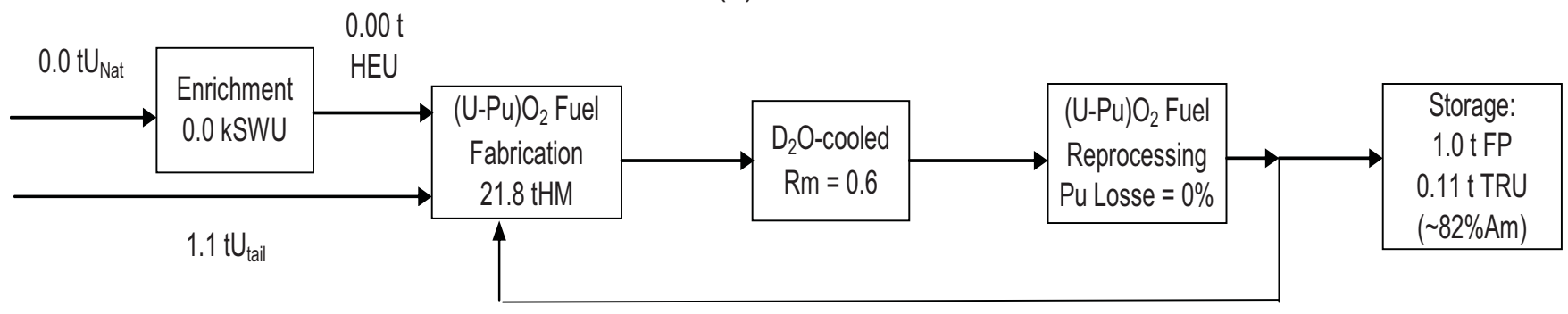

$17.1 \mathrm{tU}+3.6 \mathrm{tPu}$

(b)

Figure 9.4. Static equilibrium annual mass flows for $1 \mathrm{GWe}$ heavy-water-cooled U-Pu reactors with water-to-fuel volume ratios of 1 (a) and 0.6 (b). Burnup $=45,000 \mathrm{MWd} / \mathrm{t}_{\mathrm{HM}}$. Energy $=8 \mathrm{TWhe}$.

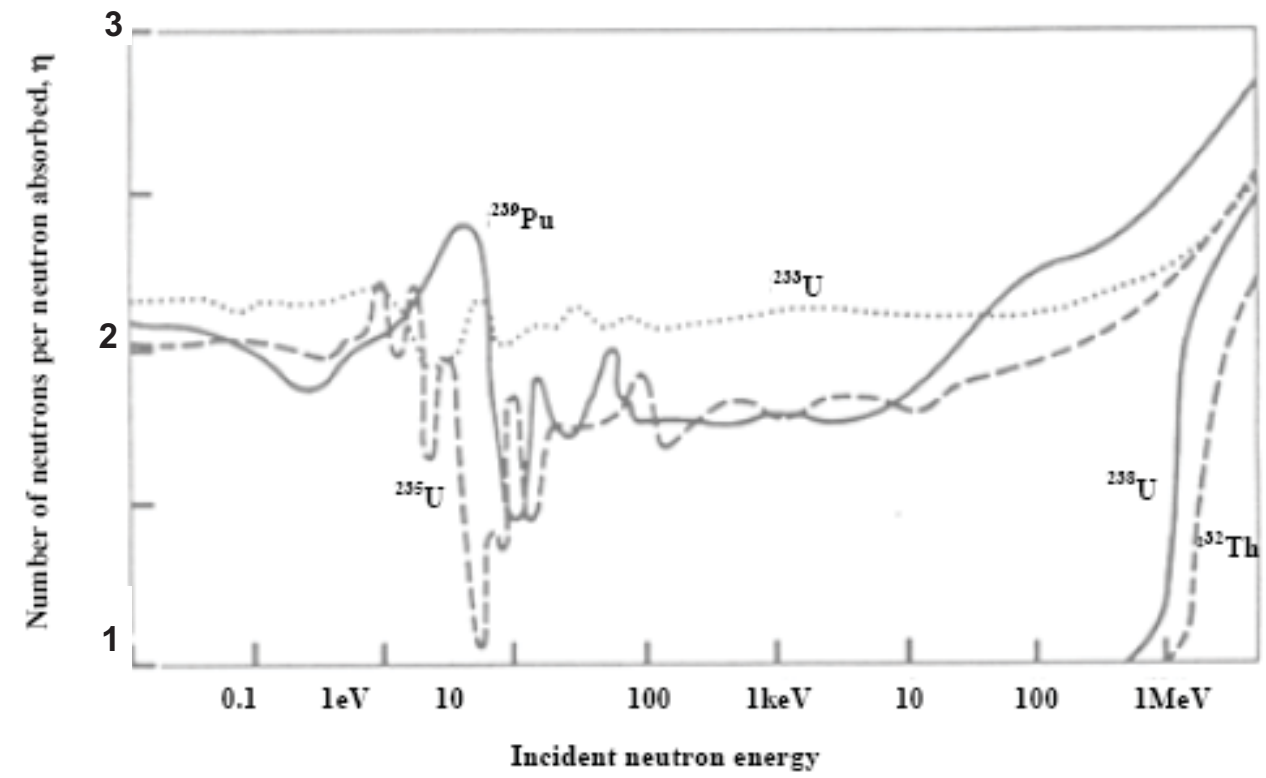

Figure 9.5. Neutron yield per neutron absorbed [9.1] 


\section{The self-sustained Th-U CANDU reactor. No free lunch.}

The lattice of a CANDU reactor is quite different from that of a PWR. It is composed of a $10 \mathrm{~cm}$ diameter tube containing $37 \mathrm{UO}_{2}$ fuel rods cooled by heavy water at a pressure of about 100 bars. The lattice pitch, i.e. the distance between the centers of two adjacent pressure tubes is $28.6 \mathrm{~cm}$ (Figure 10.1). The waterto-fuel volume ratio in the core, which is about 2 in a standard PWR, is about 20 in a CANDU reactor which provides enough space for the neutrons to slow down.

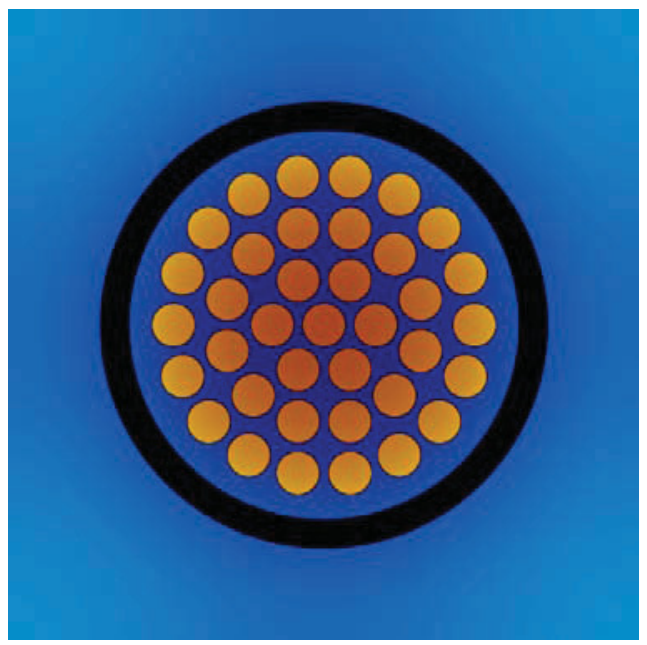

Figure 10.1. CANDU elementary cell. Lattice pitch $=28.6 \mathrm{~cm}$.

Investigations on self-sustained Th-U fuel cycle in CANDU reactors are under way especially in India and Canada (see for example [1.1]). Due to the good neutron economy of these reactors, it is believed that by recycling the bred $U$ a self-sustained Th-U can be reached. Reference [10.1] shows that the $U$ concentration after 10 cycles is about $17 \mathrm{~kg} / \mathrm{tIHM}$ and that it is made up of $70 \%$ of U233, $24 \%$ of U234, $4 \%$ of $\mathrm{U} 235$ and $2 \%$ of $\mathrm{U} 236$.

However, as mentioned in Ref [1.1], "the major shortcoming of the self-sufficient equilibrium thorium cycle is its low burnup, between 10,000 and $15,000 \mathrm{MWd} / \mathrm{t}$, which will not be economic in a cycle that requires reprocessing and remote fabrication of the U233-bearing fuel. To address this issue, a small amount of U235 make-up could be added to each cycle, allowing the burnup to be increased as desired." This is where the "no free lunch" is coming from, indeed in a fuel cycle requiring reprocessing, the fuel burnup should be as high as possible to minimize the amount of fuel to reprocess. 
From the data presented in [10.1], the annual mass flows can be estimated considering, as a first order approximation, the same load factor and the same thermal-electrical conversion efficiency as for the PWRs investigated in this report. As the burnup is comprised between 10,000 and 15,000 MWd/t, the amount of fuel to fabricate and reprocess is much higher than for the PWRs cases presented in this report, i.e. between 65 and 100 t/GWe.year (Figure 10.2).

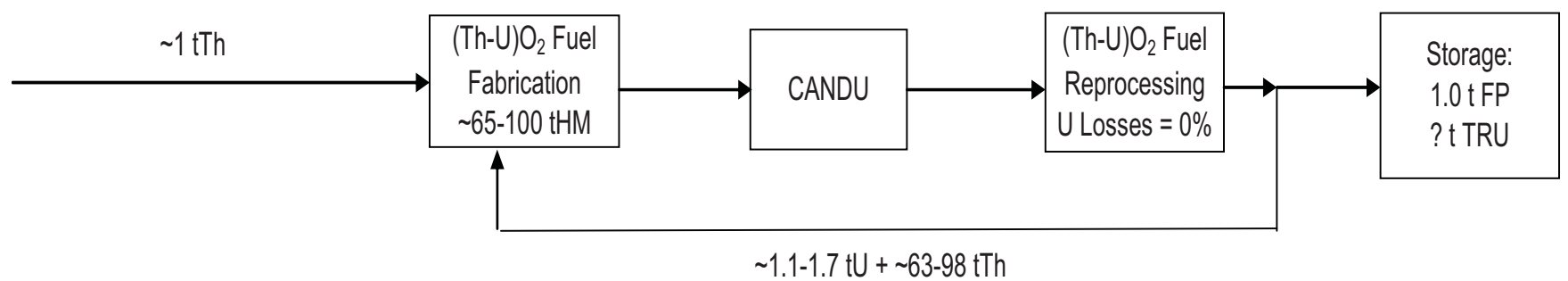

Figure 10.2. Static equilibrium annual mass flows for $1 \mathrm{GWe}$ CANDU Th-U reactors. Burnup between 10,000 and $15,000 \mathrm{MWd} / \mathrm{t}_{\text {HM }}$. Energy $=8 \mathrm{TWhe}$. Data from [10.1].

Furthermore, these calculations considered that there was enough U233 available to start the Th-U CANDU (the way to breed it is presented in [10.1]). If instead of U233, HEU is used for the first core, in a way similar to what was done in this report, the isotopic composition of the $U$ would be different. Especially, there would be more U236, a neutron poison in the CANDU thermal spectrum, which could substantially lower the burnup of the self-sustained fuel, hence further increasing the amount of fuel to fabricate and to reprocess. 


\section{Conclusions}

The Th-U fuel cycle is not quite self-sustainable when used in water-cooled reactors and with fuel burnups higher than a few thousand MWd/t characteristic of CANDU reactors operating with a continuous refueling. For the other industrially mature water-cooled reactors (i.e. PWRs and BWRs) it is economically necessary that the fuel has enough reactivity to reach fuel burnups of at least $40,000 \mathrm{MWd} / \mathrm{t}$. In this particular case, an additional input of fissile material is necessary to complement the bred fissile U-233. This additional fissile material could be included in the form of Highly Enriched Uranium (HEU) at the fabrication of the Th-U fuel (see Figure below).

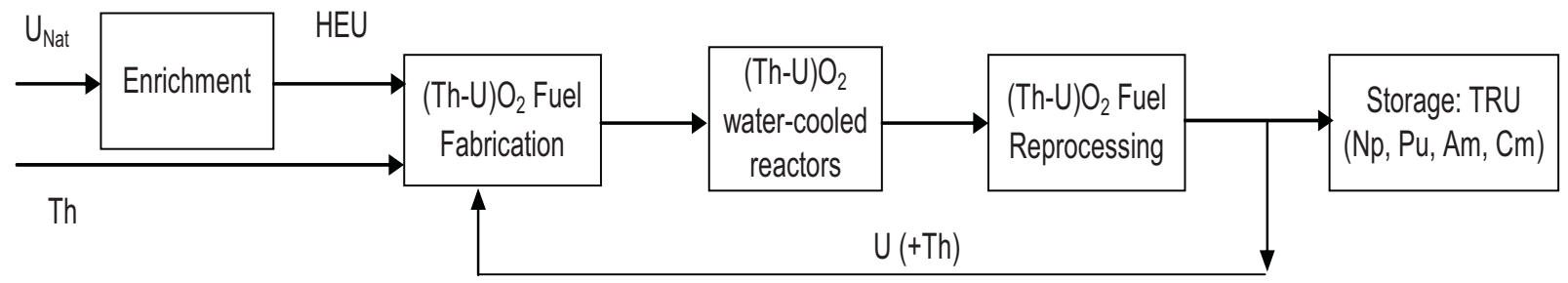

The objective of this preliminary neutronic scoping study is to determine (1) how much HEU and, consequently, how much natural uranium is necessary in such Th-U fuel cycle with $U$ recycling and (2) how much TRansUranics (TRU=Pu, Np, $\mathrm{Am}$ and $\mathrm{Cm}$ ) are produced. These numbers are then compared with those of a standard $\mathrm{UO}_{2}$ PWR. The Th-based fuels with $U$ recycling have also been compared with U-Pu fuels with Pu recycling.

The thorium reactors considered have a homogeneous hexagonal lattice made up of the same (Th-U) $\mathrm{O}_{2}$ pin. The lattice pitch has been varied to estimate the effect of the water-to-fuel volume ratio (values ranging from 2 to 0.6 have been investigated), and light water as well as heavy water have been considered.

Light-water-cooled Th-U reactors. Depending on the water-to-fuel volume ratio, between 1.5 tons and 2.5 tons of $U$ are reprocessed per GWe.year. These Th-U fuels produce between 2 and 3.5 times less TRU than the reference $\mathrm{UO}_{2}$ reactor. Compared with the reference $\mathrm{UO}_{2}$ reactor the Th- $\mathrm{U}$ reactors need between $40 \%$ and $45 \%$ less natural $U$. The influence of the water-to-fuel volume ratio is not very large and, as far as natural $U$ utilization goes, there is no incentive to use a tight lattice when $\mathrm{H}_{2} \mathrm{O}$ is the coolant.

Heavy-water-cooled Th-U reactors. Depending on the water-to-fuel volume ratio, between 3.4 tons and 4.1 tons of $U$ are reprocessed per GWe.year. These Th-U fuels produce between 1.5 and 3.5 times less $T R U$ than the reference $\mathrm{UO}_{2}$ reactor. Compared with the reference $\mathrm{UO}_{2}$ reactor the Th-U reactors need 
between $50 \%$ and $95 \%$ less natural U depending on the water-to-fuel volume ratio. Unlike with light water, there is here a strong incentive to use a tight lattice when heavy water is the coolant since the amount of HEU that must be added decreases rapidly with the water-to-fuel volume ratio. The tight-pitch heavywater-cooled reactors are very close to being self-sustained and the use of Thorium blankets outside or inside the core may produce enough $U$ to reach self-sustainability. This aspect has not been investigated and should be treated in the future.

Loading Pu from the existing stockpile into heavy-water-cooled Th-based fuel reactors. In order to limit the initial needs in HEU for the first core, the Pu present in the existing stockpile could be used. At the end of each cycle, U\&Pu (\&Th) are recycled back into the reactor with the HEU topping necessary to reach the target burnup. The amount of HEU that needs to be added per GWe.year is relatively similar to that obtained for the Th-U cases but the overall $U$ utilization is improved because of the lower initial investment in HEU. This could be a way to get rid of the existing Pu present in the spent fuel ( $\sim 800$ tons in the US) while at the same time producing U233 and transitioning to a Th-U fuel cycle.

What about loading $\mathrm{Pu}$ from the existing stockpile into heavy-water-cooled U-based fuel (i.e. MOX) reactors?

The heavy-water-cooled U-Pu cores have unacceptable intrinsic characteristics: positive water temperature coefficient and potentially positive reactivity under LOCA for large 3000 MWth cores (i.e. $30 \mathrm{~m}^{3}$ cores). Even though these unacceptable intrinsic characteristics, the natural $U$ utilization in these tight-pitch heavy-water-cooled reactors loaded with U-Pu fuel have been calculated. For the water-to-fuel volume ratio of 1 , it is about a factor of two lower than that obtained with Th-U-Pu fuel, whereas for the water-to-fuel volume ratio of 0.6 it is similar. On the other hand the TRU production of the U-Pu fuel is about twice that of the Th-U-Pu fuel. If light water and heavy water are mixed to render the safety coefficients more acceptable, the natural $U$ utilization will be lower and consequently the amount of natural $U$ necessary to run these (U-Pu) reactors will increase. The U-Pu fuel cycle is intrinsically more sensitive to the neutron spectrum (and consequently to the characteristics of the coolant) than the Th- $U$ fuel cycle because of the behavior of the Pu239 and U233 cross-sections as a function of the neutron energy. 


\section{References}

[1.1] "Thorium fuel cycle - Potential benefits and challenges", IAEA-TECDOC-1450, http://www-pub.iaea.org/MTCD/publications/PDF/te 1450 web.pdf

[1.2] "Potential of thorium based fuel cycles to constrain plutonium and reduce long lived waste toxicity", IAEA-TECDOC-1349, http://www-pub.iaea.org/MTCD/publications/PDF/te 1349 web.pdf

[1.3] "Thorium fuel utilization: Options and trends", IAEA-TECDOC-1319, http://www-pub.iaea.org/MTCD/publications/PDF/te 1319 web.pdf

[1.4] "Thorium based fuel options for the generation of electricity: Development in the 1990's", IAEA-TECDOC-1155, http://www-pub.iaea.org/MTCD/publications/PDF/te 1155 prn.pdf.

[1.5] Report on the Effect the Low Enriched Uranium Delivered Under the Highly Enriched Uranium Agreement Between the Government of the United States of America and the Government of the Russian Federation has on the Domestic Uranium Mining, Conversion, and Enrichment Industries and the Operation of the Gaseous Diffusion Plant, 2008 http://www.ne.doe.gov/pdfFiles/2008 HeuReport.pdf

[1.6] G. L. Olson, R. K. McCardell, D. B. Illum, "Fuel Summary Report: Shippingport Light Water Breeder Reactor", INEEL/EXT-98-00799 Rev. 2, Sept. 2002 http://www.inl.gov/technicalpublications/Documents/2664750.pdf

[2.1] C.A. Wemple, H-N.M. Gheorghiu, R.J.J. Stamm'ler, E.A. Villarino, "Recent Advances in the HELIOS-2 Lattice Physics Code", International Conference on the Physics of Reactors - Nuclear Power: A Sustainable Resource, Interlaken, Switzerland, September 14-19, 2008 http://www.studsvikscandpower.com/documents/publications/fp151.pdf

[2.2] Chadwick M B, et al., "ENDF/B-VII.0: Next Generation Evaluated Nuclear Data Library for Nuclear Science and Technology," Nuclear Data Sheets 107, 2931 (2006)

[2.3] "The Nuclear Fuel Cycle: Analysis and Management, 2nd Edition", (1999), page 62, Cochran \& Tsoulfanidis, American Nuclear Society.

[2.4a] M. C. Edlun, "High Conversion Ratio Plutonium Recycle in Pressurized Water Reactors", Annals of Nuclear Energy, Vol. 2. (1975)

[2.4b] Y. Ronen and A. Sharon, "Plate vs. Rod Fuel Elements in a Tight-Lattice Water Reactor", Annals of Nuclear Energy, Vol. 10, No. 5 (1983)

[2.4c] K. Hibi, S. Shimada, T. Okubo, T. Iwamura, S. Wada, "Conceptual Designing of ReducedModeration Water Reactor with Heavy Water Coolant", Nuclear Engineering and Design 210 (2001) 
[3.1] "Introduction to CANDU - A Short course", http://canteach.candu.org/library/19980101.pdf, slide 20 (CANTEACH is a non-commercial project supported by all Canadian nuclear utilities, major universities and industry associations)

[3.2] "Nuclear Reactor Engineering - Reactor Systems Engineering", Fourth Edition, Volume 2, page 689, Samuel Glasstone \& Alexander Sesonske

[3.3] "Radiation Protection" By Jan Burnham, New Brunswick Power Corporation, Chapter 8: Internal dose, page 236, http://canteach.candu.org/library/20031300.pdf

[6.1] G. Aliberti, G. Palmiotti, M. Salvatores, T.K. Kim, T.A. Taiwo, M. Anitescu, I. Kodeli, E. Sartori, J.C. Bosq, J. Tommasi, "Nuclear data sensitivity, uncertainty and target accuracy assessment for future nuclear systems", Annals of Nuclear Energy 33 (2006) 700-733

[6.2] "The Future of the Nuclear Fuel Cycle - An Interdisciplinary MIT Study" (2010) http://web.mit.edu/mitei/docs/spotlights/nuclear-fuel-cycle.pdf

[9.1] Lung M. and Gremm O., "Perspectives on Thorium Fuel Cycle", Nuclear Engineering and Design, 180 (1998) 130-146.

[10.1] B. R. Bergelson, A. S. Gerasimov and G. V. Tikhomirov, "Operation of CANDU power reactor in thorium self-sufficient fuel cycle", PRAMANA Journal of Physics pp. 143-150, Vol. 68, No. 2 (February 2007), Indian Academy of Sciences, http://www.ias.ac.in/pramana/v68/p143/fulltext.pdf 


\section{Appendix A}

\section{The $232 \mathrm{U}$ issue}

For more details, see "Thorium fuel cycle - Potential benefits and challenges",

IAEA-TECDOC-1450, http://www-pub.iaea.org/MTCD/publications/PDF/te 1450 web.pdf

In irradiated $232 \mathrm{Th}$ fuels, $232 \mathrm{U}$ is also formed along with the bred $233 \mathrm{U}$. The $232 \mathrm{U}$ is mainly generated from thorium as a result of the $6.37 \mathrm{MeV}$ threshold $(n, 2 n)$ reaction and also from the $(n, 2 n)$ reaction with $233 \mathrm{~Pa}$ and $233 \mathrm{U}$. $232 \mathrm{U}$ emits alpha particles and has a half-life of 73.6 years. Radiation hazard mainly arises due to build-up of the gamma emitting, short-lived daughter products of $228 \mathrm{Th}$, namely $212 \mathrm{~Pb}$, 212Bi and 208TI, particularly 208TI, which emits $2.6 \mathrm{MeV}$ gamma radiation. 232U cannot be chemically separated from the recovered 233U. Likewise, 228Th cannot be chemically separated from the recovered thorium in the reprocessing plant. As a result, both $233 \mathrm{U}$ and 228Th, which are recovered from reprocessing the spent thorium fuel cycle cores, develop high-energy gamma radiation fields on standing. Hence, remote reprocessing and re-fabrication are needed.

The figure below shows the dose rate from $5 \mathrm{~kg}$ (approximate critical mass) 233U containing 100, 1000 and $10000 \mathrm{ppm} 232 \mathrm{U}$ at various time interval after chemical separation and the LD-50 line indicating $50 \%$ chance of death following one hour exposure. The gamma activity provides adequate barrier to diversion, particularly when the $232 \mathrm{U}$ content is in the higher range.

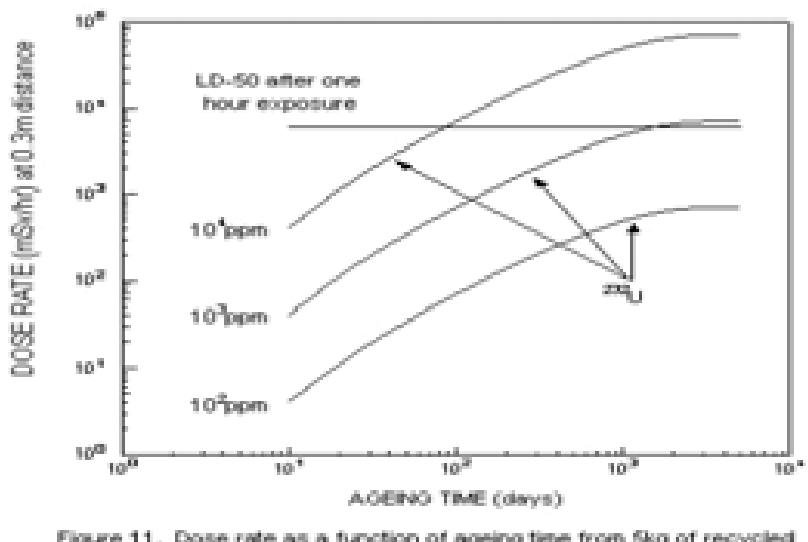

min corkarinuted won $2 x$

However, the presence of $232 \mathrm{U}$ will pose problem during reprocessing and re-fabrication because of the need of very thick lead shielding to reduce the gamma dose. The lead shielding thickness in $\mathrm{cm}$ necessary to reduce the gamma dose rate at $1 \mathrm{~m}$ distance to $2.5 \mu \mathrm{Sv} / \mathrm{h}$ from $1 \mathrm{~kg} 233 \mathrm{U}$ with various concentration of $232 \mathrm{U}$ as a function of the ageing time after chemical purification is given below: 
Improving Natural Uranium Utilization by Using Thorium in Low Moderation PWRs

\section{Ageing time in days}

$\begin{array}{llllll}{ }^{232} \mathbf{U} /{ }^{233} \mathbf{U} & 10 & 30 & 100 & 400 & 4000 \\ & & & & & \\ 100 \mathrm{ppm} & 6.75 \mathrm{~cm} & 10.4 \mathrm{~cm} & 13.3 \mathrm{~cm} & 16.4 \mathrm{~cm} & 18.4 \mathrm{~cm} \\ 1000 \mathrm{ppm} & 12.1 \mathrm{~cm} & 15.5 \mathrm{~cm} & 18.4 \mathrm{~cm} & 21.5 \mathrm{~cm} & 23.5 \mathrm{~cm} \\ 10000 \mathrm{ppm} & 17.2 \mathrm{~cm} & 20.8 \mathrm{~cm} & 23.5 \mathrm{~cm} & 26.0 \mathrm{~cm} & 28.1 \mathrm{~cm}\end{array}$




\title{
Appendix B
}

\author{
Impact of the HEU isotopic composition: \\ The case of an HEU' made up of 50\% U-235 and 50\% U-238 \\ Heavy-water-cooled - Burnup $=45,000 \mathrm{MWd} / \mathrm{t}$
}

\section{Case 1: Plutonium is not recycled}

Core physics aspects. The percentage of HEU' for the first cycle is not very dependant on the water-tofuel volume ratio: $31.1 \%$ and $29.6 \%$ for water-to-fuel volume ratios of, respectively, 1 and 0.6 . The reactivity losses per cycle $(15,000 \mathrm{MWd} / \mathrm{t})$ are between 1500 and $3000 \mathrm{pcm}$ for the water-to-fuel volume ratio of 1 and between 1000 and 2000 pcm for the water-to-fuel volume ratio of 0.6 .

In order to maintain negative water temperature coefficients between $10 \%$ and $15 \%$ of $\mathrm{H}_{2} \mathrm{O}$ must be added to the $\mathrm{D}_{2} \mathrm{O}$ for the water-to-fuel volume ratio of 1 and about $15 \%$ the water-to-fuel volume ratio of 0.6. The water temperature coefficient is between 0 and $-10 \mathrm{pcm} /{ }^{\circ} \mathrm{C}$.

Evolution of $U$ isotopic concentrations during recycling. Figures B.1 ( $a$ \& b) show the evolution of the $\mathrm{U}$ isotopic concentrations during recycling and for two water-to-fuel volume ratios ( 1 and 0.6 ). The U233 concentrations reach lower equilibrium values than those reached with the 90-10 HEU, i.e. between about $55 \mathrm{~kg} / \mathrm{tlHM}$ and $65 \mathrm{~kg} / \mathrm{tlHM}$ against between about $80 \mathrm{~kg} / \mathrm{tlHM}$ and $90 \mathrm{~kg} / \mathrm{tlHM}$ when the 90-10 HEU is used. The U238 concentration which reaches an equilibrium concentration at about $10 \mathrm{~kg} / \mathrm{tlHM}$ with the 90-10 HEU reaches here, with the 50-50 HEU, values between $180 \mathrm{~kg} / \mathrm{tlHM}$ and $230 \mathrm{~kg} / \mathrm{tlHM}$. The concentration of U232 saturates at a value of about $0.04-0.05 \mathrm{~kg} / \mathrm{tlHM}$ which corresponds to a ratio U232/Utot comprised between 100 ppm and 200 ppm.

Since the amount of uranium in this thorium fuel using the 50-50 HEU is more important than in the thorium fuel using the 90-10 HEU, so is the amount of Pu produced. It is about $7 \mathrm{~kg} / \mathrm{tlHM}$ at the first recycling and it increases to about $10-11 \mathrm{~kg} / \mathrm{tIHM}$ at the $10^{\text {th }}$ recycling (see details of the amount TRU that needs to be disposed of in Tables B1 \& B2). The percentage of Pu239 is very important: between 85\% and $90 \%$. 


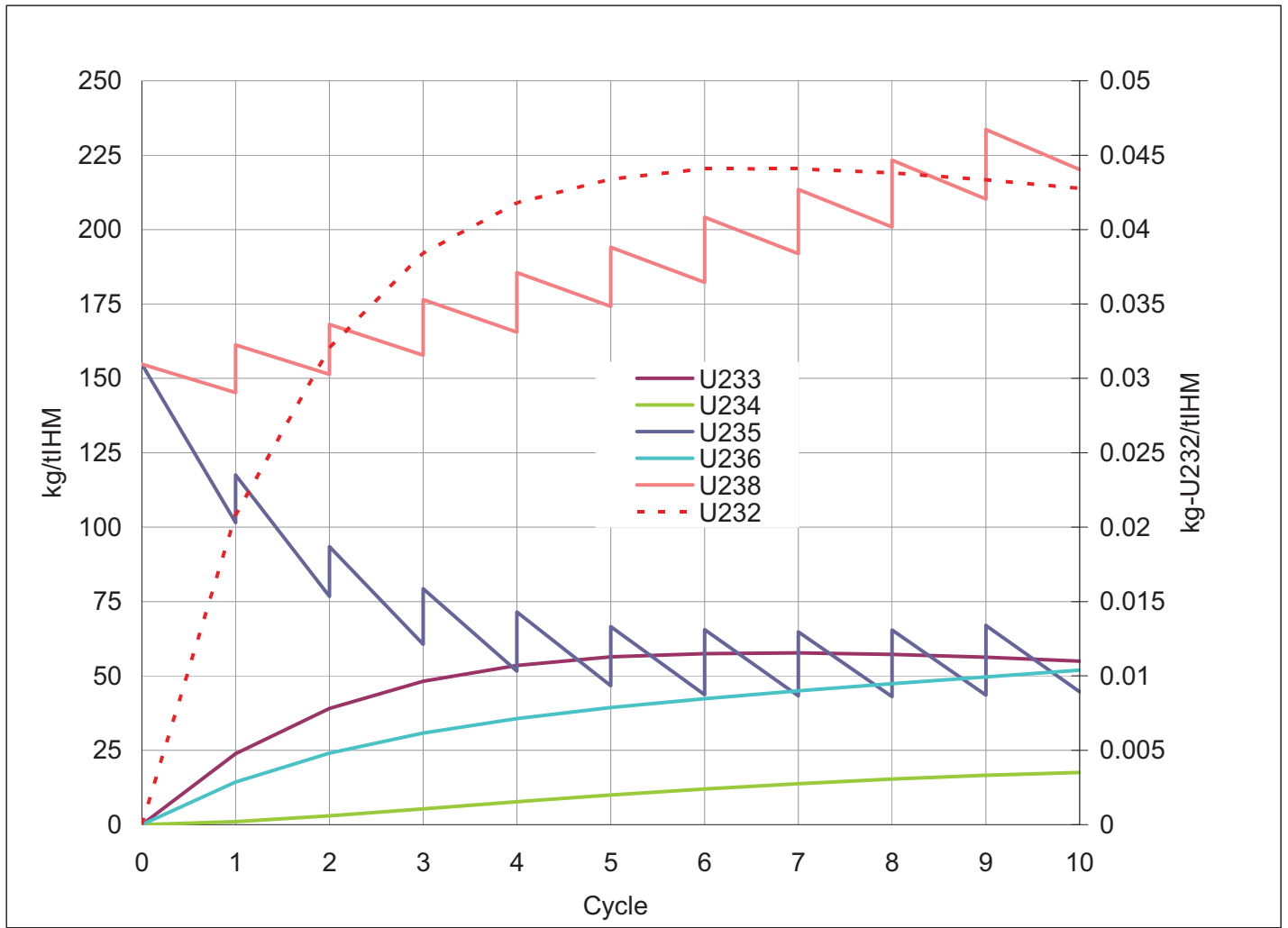

Figure B.1a. Evolution of $U$ concentration at fabrication and reprocessing of the Th- $U$ fuel $(\mathrm{kg} / \mathrm{tlHM})$. water-to-fuel volume ratio $=1$. Burnup $=45,000 \mathrm{MWd} / \mathrm{t}_{\mathrm{HM}}$.

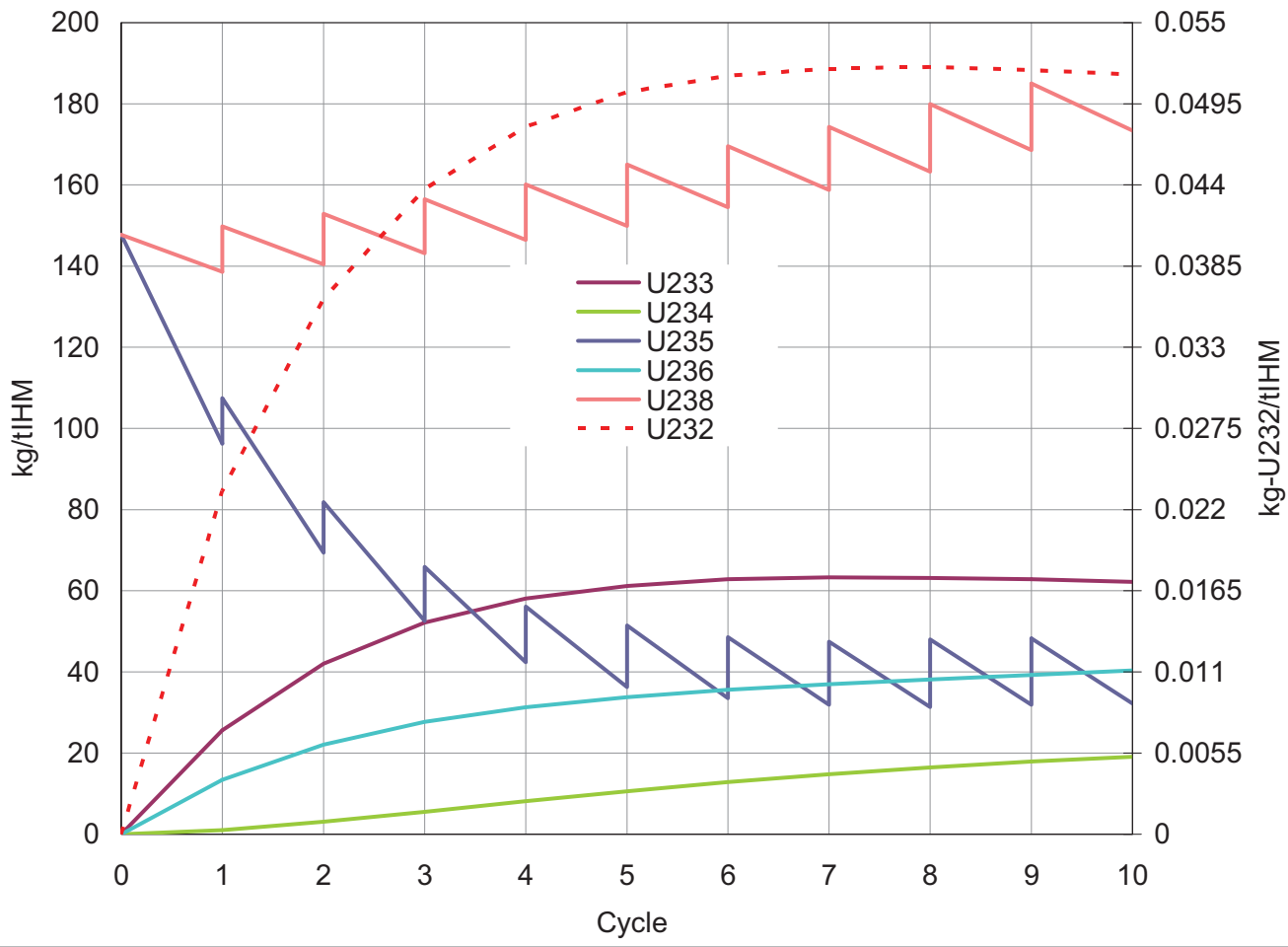

Figure B.1b. Evolution of $U$ concentration at fabrication and reprocessing of the Th- $U$ fuel $(\mathrm{kg} / \mathrm{tlHM})$. water-to-fuel volume ratio $=0.6$ Burnup $=45,000 \mathrm{GWd} / \mathrm{t}_{\mathrm{HM}}$. 
Mass Flows. Figure B.2 below presents the annual mass flows for the $10^{\text {th }}$ cycle for a Th-U reactor characterized by a water-to-fuel volume ratio of 1 and 0.6. Since the amount of U233 created is lower when the 50-50 HEU is used than when the 90-10 HEU is used it is necessary to add more HEU which means more natural uranium. Whereas the natural $U$ needs were between 10 and $40 \mathrm{t} / \mathrm{GWe}$.year with the 90-10 HEU (Figure 6.1.2) they are comprised here between 75 and $110 \mathrm{t} / \mathrm{GWe}$.year. The gain relative to the standard $\mathrm{UO}_{2}$ PWR which necessitates about $170 \mathrm{t} / \mathrm{GWe}$.year is drastically reduced.

These Th-U fuels produce up to almost $30 \%$ more TRU than the reference $\mathrm{UO}_{2}$ reactor. Furthermore $\mathrm{Pu}$ constitutes about $75 \%$ of the TRU production and this $\mathrm{Pu}$ is made up of between $85 \%$ and $90 \%$ Pu239, i.e. very fissile. Hence, using a 50-50 HEU would make more sense if Pu was recycled together with $\mathrm{U}$. This aspect is investigated in the next paragraph.

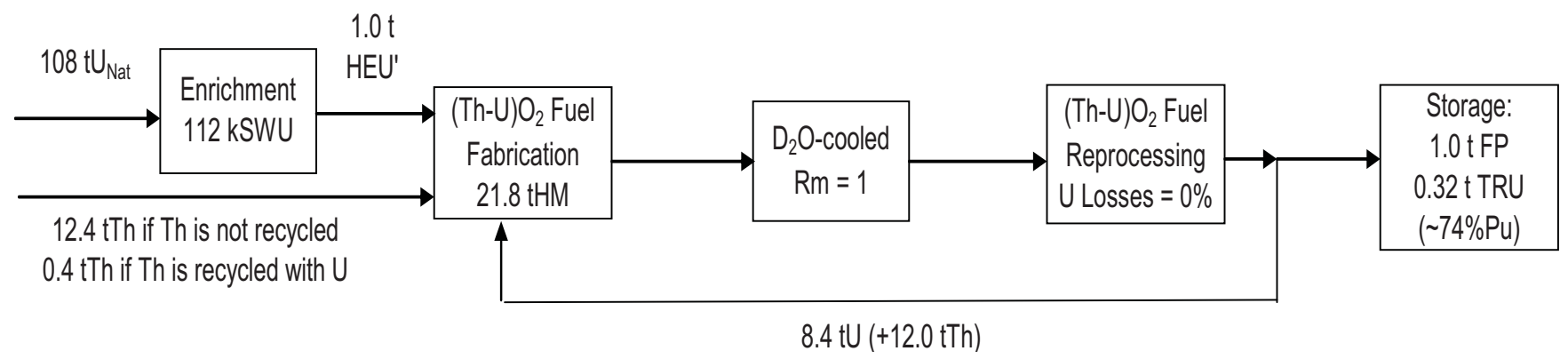

(a)

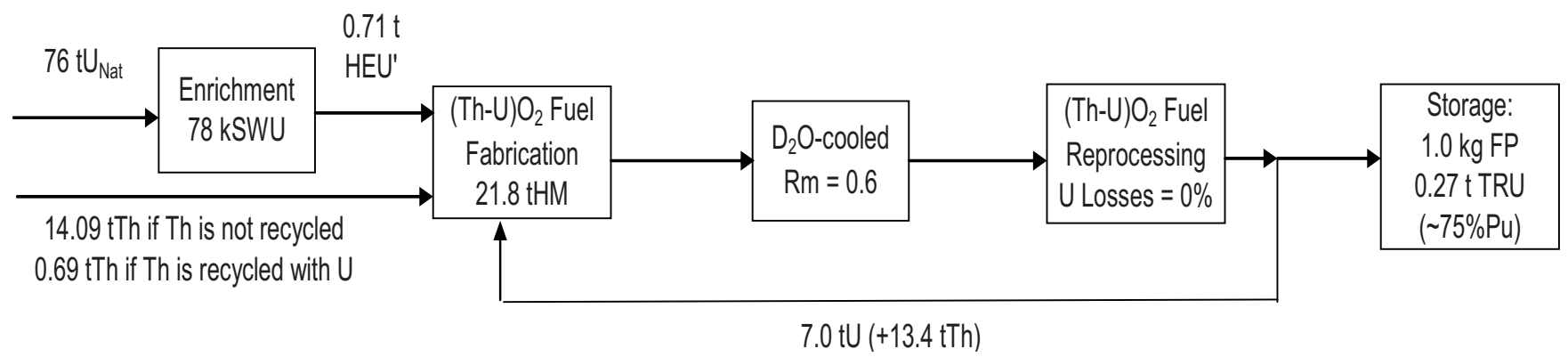

(b)

Figure B.2. Static equilibrium annual mass flows for $1 \mathrm{GWe}$ heavy-water-cooled Thorium reactors with water-to-fuel volume ratio of 1 (a) and 0.6 (b). Burnup $=45,000 \mathrm{MWd} / \mathrm{t}_{\mathrm{HM}}$. Energy $=8 \mathrm{TWhe}$. 
Improving Natural Uranium Utilization by Using Thorium in Low Moderation PWRs

Table B.1. Heavy-water-to-fuel volume ratio $=1-45,000 \mathrm{MWd} / \mathrm{t}-\mathrm{Th}-\mathrm{U}$ fuel -10 years after discharge

\begin{tabular}{|c|c|c|c|c|c|c|c|c|c|c|c|}
\hline $\mathrm{kg} / \mathrm{tlHM}$ & UO2 & Repro. 1 & Repro. 2 & Repro. 3 & Repro. 4 & Repro. 5 & Repro. 6 & Repro. 7 & Repro. 8 & Repro. 9 & Repro. 10 \\
\hline $\mathrm{Pa} 231$ & 0 & 1.4E-01 & 1.4E-01 & $1.4 \mathrm{E}-01$ & 1.3E-01 & 1.3E-01 & $1.3 \mathrm{E}$ & $1.3 \mathrm{E}$ & $1.2 \mathrm{E}-01$ & $1.2 \mathrm{E}-01$ & $1.2 \mathrm{E}-01$ \\
\hline Np237 & $6.3 \mathrm{E}-01$ & $7.8 \mathrm{E}-01$ & $1.6 \mathrm{E}+00$ & $2.2 \mathrm{E}+00$ & $2.6 \mathrm{E}+00$ & $2.8 \mathrm{E}+00$ & $3.1 \mathrm{E}+00$ & $3.2 \mathrm{E}+00$ & $3.4 \mathrm{E}+00$ & $3.5 \mathrm{E}+00$ & $3.6 \mathrm{E}+00$ \\
\hline Pu238 & $2.9 \mathrm{E}-01$ & 1.0E-01 & 2.6E-01 & 3.7E-01 & 4.4E-01 & 4.9E-01 & $5.4 \mathrm{E}-01$ & $5.6 \mathrm{E}-01$ & 5.9E-01 & $6.2 \mathrm{E}-01$ & $6.4 \mathrm{E}-01$ \\
\hline Pu239 & $6.2 \mathrm{E}+00$ & $6.9 \mathrm{E}+00$ & $7.2 \mathrm{E}+00$ & $7.6 \mathrm{E}+00$ & $7.9 E+00$ & $8.2 E+00$ & $8.5 E+00$ & $8.8 \mathrm{E}+00$ & $9.1 \mathrm{E}+00$ & $9.4 \mathrm{E}+00$ & $9.6 \mathrm{E}+00$ \\
\hline Pu240 & $2.9 \mathrm{E}+00$ & 5.5E-01 & 5.9E-01 & $6.3 \mathrm{E}-01$ & 6.6E-01 & 6.9E-01 & 7.2E-01 & 7.5E-01 & 7.7E-01 & 8.0E-01 & 8.2E-01 \\
\hline Pu241 & $1.1 \mathrm{E}+00$ & $5.3 \mathrm{E}-02$ & 4.4E-02 & 4.6E-02 & 4.7E-02 & $4.8 \mathrm{E}-02$ & $5.4 \mathrm{E}-02$ & $5.5 \mathrm{E}-02$ & $6.0 \mathrm{E}-02$ & $6.6 \mathrm{E}-02$ & 7.1E-02 \\
\hline Pu242 & 8.6E-01 & $3.1 \mathrm{E}-03$ & $2.4 \mathrm{E}-03$ & $2.6 \mathrm{E}-03$ & 2.7E-03 & 2.7E-03 & $3.1 \mathrm{E}-03$ & $3.1 \mathrm{E}-03$ & 3.5E-03 & $3.8 \mathrm{E}-03$ & $4.2 \mathrm{E}-03$ \\
\hline Am241 & 7.3E-01 & $3.9 \mathrm{E}-02$ & $3.2 \mathrm{E}-02$ & 3.3E-02 & $3.4 \mathrm{E}-02$ & $3.5 \mathrm{E}-02$ & $3.9 \mathrm{E}-02$ & $3.9 \mathrm{E}-02$ & 4.3E-02 & 4.7E-02 & $5.1 \mathrm{E}-02$ \\
\hline Am242m & $8.2 \mathrm{E}-04$ & 5.7E-05 & 4.2E-05 & 4.3E-05 & 4.4E-05 & $4.5 \mathrm{E}-05$ & $5.2 \mathrm{E}-05$ & $5.2 \mathrm{E}-05$ & $5.8 \mathrm{E}-05$ & $6.5 \mathrm{E}-05$ & $7.2 \mathrm{E}-05$ \\
\hline Am243 & 2.0E-01 & $2.2 \mathrm{E}-04$ & $1.4 \mathrm{E}-04$ & $1.5 \mathrm{E}-04$ & $1.5 \mathrm{E}-04$ & $1.5 \mathrm{E}-04$ & $1.8 \mathrm{E}-04$ & $1.8 \mathrm{E}-04$ & 2.1E-04 & $2.5 \mathrm{E}-04$ & $2.9 \mathrm{E}-04$ \\
\hline $\mathrm{Cm} 242$ & $2.0 \mathrm{E}-06$ & $1.5 \mathrm{E}-07$ & 1.1E-07 & $1.1 \mathrm{E}-07$ & $1.2 \mathrm{E}-07$ & $1.2 \mathrm{E}-07$ & $1.4 \mathrm{E}-07$ & $1.4 \mathrm{E}-07$ & $1.5 \mathrm{E}-07$ & 1.7E-07 & $1.9 \mathrm{E}-07$ \\
\hline $\mathrm{Cm} 243$ & $6.0 \mathrm{E}-04$ & $3.3 \mathrm{E}-06$ & $2.4 \mathrm{E}-06$ & $2.6 \mathrm{E}-06$ & 2.7E-06 & 2.7E-06 & 3.1E-06 & $3.1 \mathrm{E}-06$ & $3.6 \mathrm{E}-06$ & 4.0E-06 & $4.4 \mathrm{E}-06$ \\
\hline $\mathrm{Cm} 244$ & $5.9 \mathrm{E}-02$ & $1.3 \mathrm{E}-05$ & 7.1E-06 & $7.2 \mathrm{E}-06$ & 7.3E-06 & 7.4E-06 & $9.1 \mathrm{E}-06$ & $9.0 \mathrm{E}-06$ & 1.1E-05 & $1.3 \mathrm{E}-05$ & $1.5 \mathrm{E}-05$ \\
\hline $\mathrm{Cm} 245$ & 5.7E-03 & 8.7E-07 & $4.5 \mathrm{E}-07$ & 4.6E-07 & 4.7E-07 & 4.7E-07 & $6.1 \mathrm{E}-07$ & $5.9 \mathrm{E}-07$ & 7.3E-07 & 8.9E-07 & $1.1 \mathrm{E}-06$ \\
\hline $\mathrm{Cm} 246$ & 7.3E-04 & $1.2 \mathrm{E}-08$ & 5.9E-09 & 6.1E-09 & 6.2E-09 & 6.2E-09 & 8.0E-09 & 7.8E-09 & 9.7E-09 & $1.2 \mathrm{E}-08$ & $1.4 \mathrm{E}-08$ \\
\hline $\mathrm{Cm} 247$ & $1.0 \mathrm{E}-05$ & 1.7E-10 & 8.3E-11 & $8.6 \mathrm{E}-11$ & 8.8E-11 & $8.8 \mathrm{E}-11$ & $1.1 \mathrm{E}-10$ & $1.1 \mathrm{E}-10$ & $1.4 \mathrm{E}-10$ & 1.7E-10 & $2.0 \mathrm{E}-10$ \\
\hline $\mathrm{Cm} 248$ & 7.7E-07 & $3.1 \mathrm{E}-12$ & $1.4 \mathrm{E}-12$ & $1.4 \mathrm{E}-12$ & $1.5 \mathrm{E}-12$ & $1.5 \mathrm{E}-12$ & $2.0 \mathrm{E}-12$ & $1.9 \mathrm{E}-12$ & $2.4 \mathrm{E}-12$ & $2.9 \mathrm{E}-12$ & $3.6 \mathrm{E}-12$ \\
\hline $\mathrm{Pa}$ & $0.0 \mathrm{E}+00$ & $1.4 \mathrm{E}-01$ & $1.4 \mathrm{E}-01$ & $1.4 \mathrm{E}-01$ & 1.3E-01 & 1.3E-01 & $1.3 \mathrm{E}-01$ & $1.3 \mathrm{E}-01$ & $1.2 \mathrm{E}-01$ & $1.2 \mathrm{E}-01$ & $1.2 \mathrm{E}-01$ \\
\hline $\mathrm{Np}$ & $6.3 \mathrm{E}-01$ & $7.8 \mathrm{E}-01$ & $1.6 \mathrm{E}+00$ & $2.2 \mathrm{E}+00$ & $2.6 \mathrm{E}+00$ & $2.8 \mathrm{E}+00$ & $3.1 E+00$ & $3.2 E+00$ & $3.4 \mathrm{E}+00$ & $3.5 \mathrm{E}+00$ & $3.6 \mathrm{E}+00$ \\
\hline $\mathrm{Pu}$ & $1.1 \mathrm{E}+01$ & $7.6 \mathrm{E}+00$ & $8.1 E+00$ & $8.6 E+00$ & $9.0 \mathrm{E}+00$ & $9.4 \mathrm{E}+00$ & $9.8 \mathrm{E}+00$ & $1.0 \mathrm{E}+01$ & $1.1 \mathrm{E}+01$ & $1.1 \mathrm{E}+01$ & $1.1 \mathrm{E}+01$ \\
\hline $\mathrm{Am}$ & $9.3 \mathrm{E}-01$ & $3.9 \mathrm{E}-02$ & $3.2 \mathrm{E}-02$ & 3.3E-02 & 3.4E-02 & $3.5 \mathrm{E}-02$ & $3.9 \mathrm{E}-02$ & 4.0E-02 & 4.3E-02 & $4.8 \mathrm{E}-02$ & $5.2 \mathrm{E}-02$ \\
\hline $\mathrm{Cm}$ & $6.6 \mathrm{E}-02$ & 1.7E-05 & $1.0 \mathrm{E}-05$ & $1.0 \mathrm{E}-05$ & 1.1E-05 & 1.1E-05 & $1.3 \mathrm{E}-05$ & $1.3 \mathrm{E}-05$ & $1.5 \mathrm{E}-05$ & $1.8 \mathrm{E}-05$ & 2.1E-05 \\
\hline Total & $1.3 E+01$ & $8.5 E+00$ & $9.9 E+00$ & $1.1 \mathrm{E}+01$ & $1.2 \mathrm{E}+01$ & $1.2 \mathrm{E}+01$ & $1.3 E+01$ & $1.4 \mathrm{E}+01$ & $1.4 \mathrm{E}+01$ & $1.4 \mathrm{E}+01$ & $1.5 \mathrm{E}+01$ \\
\hline
\end{tabular}

Table B.2. Heavy-water-to-fuel volume ratio $=0.6-45,000 \mathrm{MWd} / \mathrm{t}-\mathrm{Th}-\mathrm{U}$ fuel -10 years after discharge

\begin{tabular}{|c|c|c|c|c|c|c|c|c|c|c|c|}
\hline $\mathrm{kg} / \mathrm{tl} \mathrm{HM}$ & UO2 & Repro. 1 & Repro. 2 & Repro. 3 & Repro. 4 & Repro. 5 & Repro. 6 & Repro. 7 & Repro. 8 & Repro. 9 & Repro. 10 \\
\hline $\mathrm{Pa} 231$ & 0 & 1.6E-01 & 1.6E-01 & $1.6 \mathrm{E}-01$ & $1.6 \mathrm{E}-01$ & 1.6E-01 & 1.6E-01 & $1.6 \mathrm{E}-01$ & $1.6 \mathrm{E}-01$ & 1.5E-01 & $1.5 \mathrm{E}-01$ \\
\hline Np237 & $6.3 \mathrm{E}-01$ & 7.1E-01 & $1.5 \mathrm{E}+00$ & $2.0 \mathrm{E}+00$ & $2.3 E+00$ & $2.5 E+00$ & $2.6 \mathrm{E}+00$ & $2.7 \mathrm{E}+00$ & $2.8 \mathrm{E}+00$ & $2.9 \mathrm{E}+00$ & $3.0 \mathrm{E}+00$ \\
\hline Pu239 & $6.2 \mathrm{E}+00$ & $6.5 \mathrm{E}+00$ & $6.7 \mathrm{E}+00$ & $7.0 \mathrm{E}+00$ & $7.1 \mathrm{E}+00$ & $7.3 \mathrm{E}+00$ & $7.5 \mathrm{E}+00$ & 7.7E+00 & $7.8 \mathrm{E}+00$ & $8.0 \mathrm{E}+00$ & $8.2 E+00$ \\
\hline Pu240 & $2.9 \mathrm{E}+00$ & 5.0E-01 & 5.3E-01 & 5.5E-01 & $5.8 \mathrm{E}-01$ & 6.0E-01 & $6.2 \mathrm{E}-01$ & $6.4 \mathrm{E}-01$ & $6.5 \mathrm{E}-01$ & 6.7E-01 & $6.8 \mathrm{E}-01$ \\
\hline Pu241 & $1.1 \mathrm{E}+00$ & 3.7E-02 & 3.1E-02 & 3.0E-02 & $3.2 \mathrm{E}-02$ & $3.5 \mathrm{E}-02$ & $3.5 \mathrm{E}-02$ & $3.8 \mathrm{E}-02$ & 4.1E-02 & 4.1E-02 & 4.4E-02 \\
\hline Am241 & 7.3E-01 & $2.8 \mathrm{E}-02$ & $2.3 \mathrm{E}-02$ & $2.2 \mathrm{E}-02$ & $2.3 \mathrm{E}-02$ & $2.6 \mathrm{E}-02$ & $2.6 \mathrm{E}-02$ & $2.8 \mathrm{E}-02$ & $3.0 \mathrm{E}-02$ & 3.0E-02 & $3.2 \mathrm{E}-02$ \\
\hline Am242m & $8.2 \mathrm{E}-04$ & $4.5 \mathrm{E}-05$ & $3.4 \mathrm{E}-05$ & 3.3E-05 & $3.4 \mathrm{E}-05$ & $3.8 \mathrm{E}-05$ & $3.9 \mathrm{E}-05$ & $4.2 \mathrm{E}-05$ & 4.6E-05 & 4.6E-05 & 5.0E-05 \\
\hline Am243 & 2.0E-01 & $1.2 \mathrm{E}-04$ & 8.1E-05 & 7.5E-05 & $7.8 \mathrm{E}-05$ & $9.2 \mathrm{E}-05$ & $9.3 \mathrm{E}-05$ & $1.1 \mathrm{E}-04$ & $1.2 \mathrm{E}-04$ & $1.2 \mathrm{E}-04$ & $1.3 \mathrm{E}-04$ \\
\hline $\mathrm{Cm} 242$ & $2.0 \mathrm{E}-06$ & $1.2 \mathrm{E}-07$ & $8.8 \mathrm{E}-08$ & 8.5E-08 & 8.9E-08 & 1.0E-07 & $1.0 \mathrm{E}-07$ & $1.1 \mathrm{E}-07$ & $1.2 \mathrm{E}-07$ & $1.2 \mathrm{E}-07$ & $1.3 \mathrm{E}-07$ \\
\hline $\mathrm{Cm} 243$ & $6.0 \mathrm{E}-04$ & $2.2 \mathrm{E}-06$ & $1.6 \mathrm{E}-06$ & 1.6E-06 & 1.7E-06 & 1.9E-06 & $2.0 \mathrm{E}-06$ & $2.2 \mathrm{E}-06$ & $2.4 \mathrm{E}-06$ & $2.4 \mathrm{E}-06$ & $2.6 \mathrm{E}-06$ \\
\hline $\mathrm{Cm} 247$ & $1.0 \mathrm{E}-05$ & $7.4 \mathrm{E}-11$ & $3.8 \mathrm{E}-11$ & $3.4 \mathrm{E}-11$ & 3.7E-11 & 4.7E-11 & 4.7E-11 & 5.7E-11 & 6.7E-11 & $6.5 \mathrm{E}-11$ & 7.5E-11 \\
\hline $\mathrm{Cm} 248$ & 7.7E-07 & $1.2 \mathrm{E}-12$ & $5.8 \mathrm{E}-13$ & $5.2 \mathrm{E}-13$ & 5.7E-13 & 7.4E-13 & 7.4E-13 & $9.1 \mathrm{E}-13$ & $1.1 \mathrm{E}-12$ & 1.0E-12 & $1.2 \mathrm{E}-12$ \\
\hline $\mathrm{Pa}$ & $0.0 \mathrm{E}+00$ & $1.6 \mathrm{E}-01$ & $1.6 \mathrm{E}-01$ & $1.6 \mathrm{E}-01$ & 1.6E-01 & $1.6 \mathrm{E}-01$ & 1.6E-01 & $1.6 \mathrm{E}-01$ & 1.6E-01 & $1.5 \mathrm{E}-01$ & $1.5 \mathrm{E}-01$ \\
\hline $\mathrm{Np}$ & $6.3 \mathrm{E}-01$ & 7.1E-01 & $1.5 \mathrm{E}+00$ & $2.0 \mathrm{E}+00$ & $2.3 E+00$ & $2.5 E+00$ & $2.6 \mathrm{E}+00$ & 2.7E+00 & $2.8 \mathrm{E}+00$ & $2.9 \mathrm{E}+00$ & $3.0 \mathrm{E}+00$ \\
\hline $\mathrm{Pu}$ & $1.1 \mathrm{E}+01$ & $7.2 \mathrm{E}+00$ & $7.5 \mathrm{E}+00$ & $7.9 \mathrm{E}+00$ & $8.1 \mathrm{E}+00$ & $8.4 \mathrm{E}+00$ & $8.6 E+00$ & $8.8 \mathrm{E}+00$ & $9.0 \mathrm{E}+00$ & $9.2 \mathrm{E}+00$ & $9.4 \mathrm{E}+00$ \\
\hline $\mathrm{Am}$ & $9.3 \mathrm{E}-01$ & $2.8 \mathrm{E}-02$ & 2.3E-02 & 2.3E-02 & 2.3E-02 & $2.6 \mathrm{E}-02$ & $2.6 \mathrm{E}-02$ & $2.8 \mathrm{E}-02$ & $3.0 \mathrm{E}-02$ & $3.0 \mathrm{E}-02$ & 3.3E-02 \\
\hline $\mathrm{Cm}$ & $6.6 \mathrm{E}-02$ & $9.0 \mathrm{E}-06$ & $5.6 \mathrm{E}-06$ & $5.2 \mathrm{E}-06$ & 5.5E-06 & $6.5 \mathrm{E}-06$ & 6.6E-06 & 7.5E-06 & 8.5E-06 & 8.4E-06 & 9.4E-06 \\
\hline Total & $1.3 \mathrm{E}+01$ & $8.1 E+00$ & $9.2 \mathrm{E}+00$ & $1.0 \mathrm{E}+01$ & $1.1 \mathrm{E}+01$ & $1.1 \mathrm{E}+01$ & $1.1 \mathrm{E}+01$ & $1.2 \mathrm{E}+01$ & $1.2 \mathrm{E}+01$ & $1.2 \mathrm{E}+01$ & $1.3 E+01$ \\
\hline
\end{tabular}




\section{Case 2: Plutonium is recycled}

We consider here that the first core is loaded, as previously, with Th-HEU' fuel and that $U$ and Pu are reprocessed (for case 1 , only $U$ is reprocessed).

Core physics aspects. The reactivity losses are similar to those without $\mathrm{Pu}$ recycling. The percentages of $\mathrm{H}_{2} \mathrm{O}$ in the heavy water, necessary to maintain negative water temperature coefficients are similar as well.

Evolution of U \& Pu isotopic concentrations during recycling. Figures B.3 \& B.4 show the evolution of the $U$ and $\mathrm{Pu}$ isotopic concentrations during recycling and for two water-to-fuel volume ratios ( 1 and 0.6). The most striking difference between the Figures A.3a-A.4a and the Figures A.1 concerns the evolution of the U238 concentration. Since Pu is recycled, less HEU' needs to be added at each fabrication and, consequently, it does not increase like on the Figures A.1.

The concentration of $\mathrm{Pu}$ increases from about $7 \mathrm{~kg} / \mathrm{tlHM}$ at the first recycling to about $30 \mathrm{~kg} / \mathrm{tlHM}$ at the $10^{\text {th }}$ recycling. In the mean time the percentage of fissile Pu isotopes (i.e. 239 and 241) goes down from about $90 \%$ to $60 \%$. Furthermore, since $\mathrm{Pu}$ is recycled, the amount of $\mathrm{Am}$ and $\mathrm{Cm}$ that have to be disposed of is higher than when $\mathrm{Pu}$ is not recycled (see details of the amount TRU that needs to be disposed of in Tables B.3 \& B.4).

Mass Flows. Figure B.5 below presents the annual mass flows for the $10^{\text {th }}$ cycle for a Th-U-Pu reactor characterized by a water-to-fuel volume ratio of 1 and 0.6 . Whereas the natural $U$ needs were between 75 and 110 t/GWe.year when Pu was not recycled (Figure B.2), they are now comprised between 25 and 50 $\mathrm{t} / \mathrm{GWe}$.year when $\mathrm{Pu}$ is recycled. The gain is natural $\mathrm{U}$ brought about by the recycling of $\mathrm{Pu}$ is important (factor of about 2 to 3), and in this case the needs in natural $U$ are close to those obtained when the 90$10 \mathrm{HEU}$ is used (i.e. between 10 and 40 t/GWe.year).

Since now Pu is recycled, the amount of TRU that need to be disposed of is similar to that obtained when the $90-10 \mathrm{HEU}$ is used (i.e. between 0.07 and 0.09 ton/GWe.year).

Hence, from the point of view of the natural $U$ utilization and of the amount TRU that needs to be disposed of, the Th-HEU' fuel (i.e. the 50-50 HEU) yields similar, though not quite as attractive, values than the Th-HEU fuel (i.e. the 90-10 HEU) only if the $\mathrm{Pu}$ is recycled together with the $\mathrm{U}$. If the $\mathrm{Pu}$ produced in the Th-HEU' is not recycled the natural $U$ utilization is much lower. 


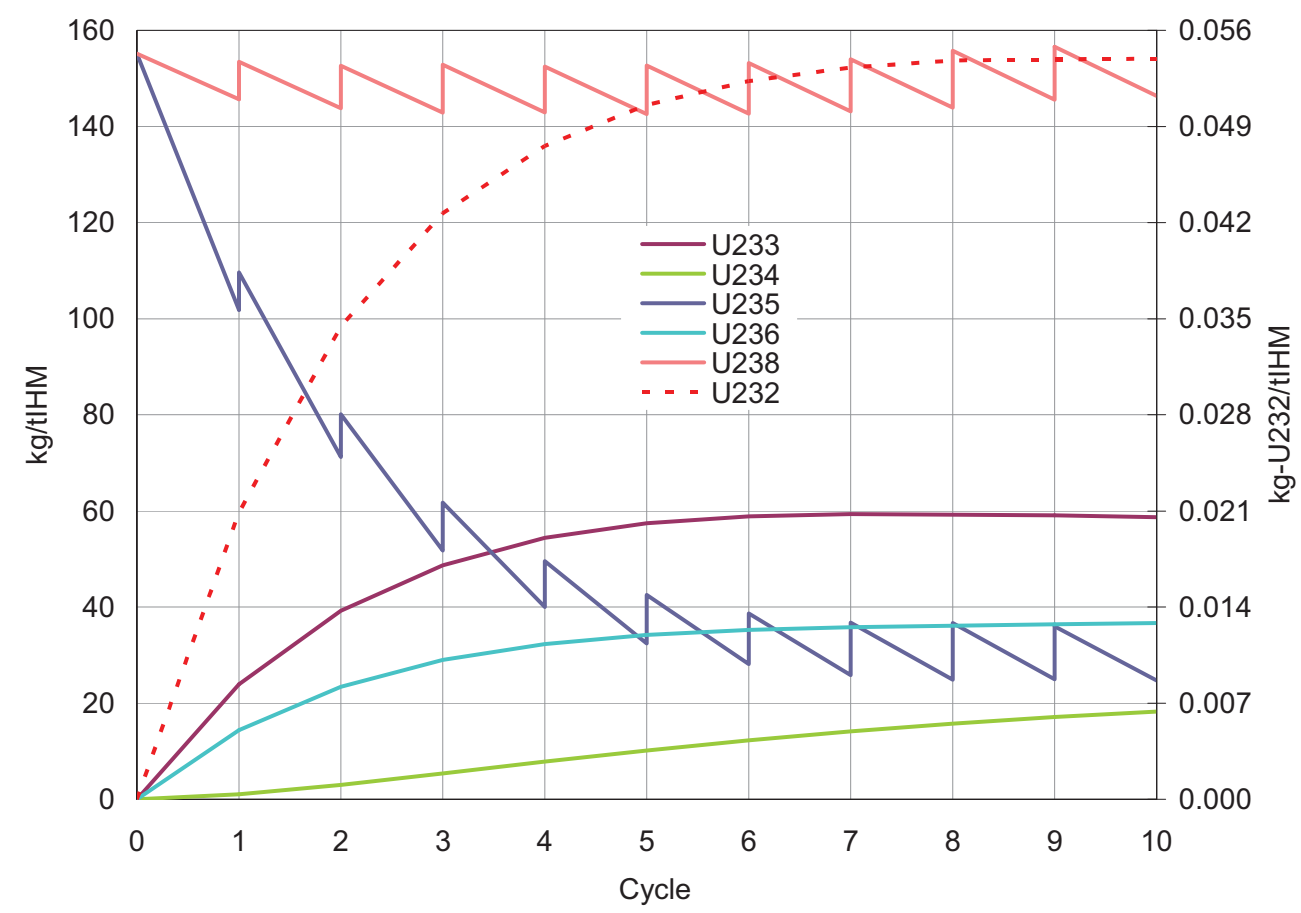

Figure B.3a. Evolution of $U$ concentration at fabrication and reprocessing of the Th-U-Pu fuel (kg/tlHM). water-to-fuel volume ratio $=1$. Burnup $=45,000 \mathrm{GWd} / \mathrm{t}_{\mathrm{HM}}$. U\&Pu are recycled.

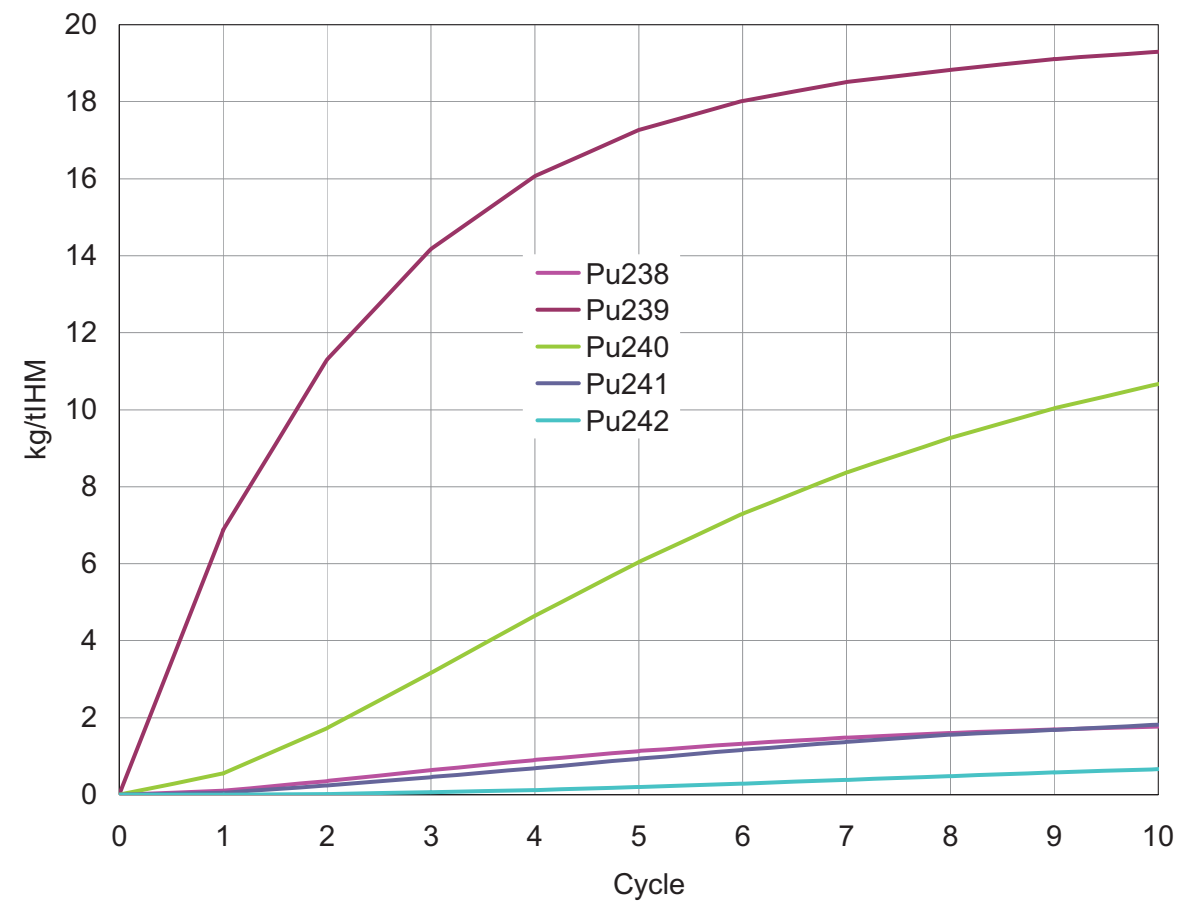

Figure B.3b. Evolution of Pu concentration at fabrication and reprocessing of the Th-U-Pu fuel (kg/tlHM). water-to-fuel volume ratio $=1$. Burnup $=45,000 \mathrm{GWd} / \mathrm{t}_{\mathrm{HM}}$. U\&Pu are recycled. 


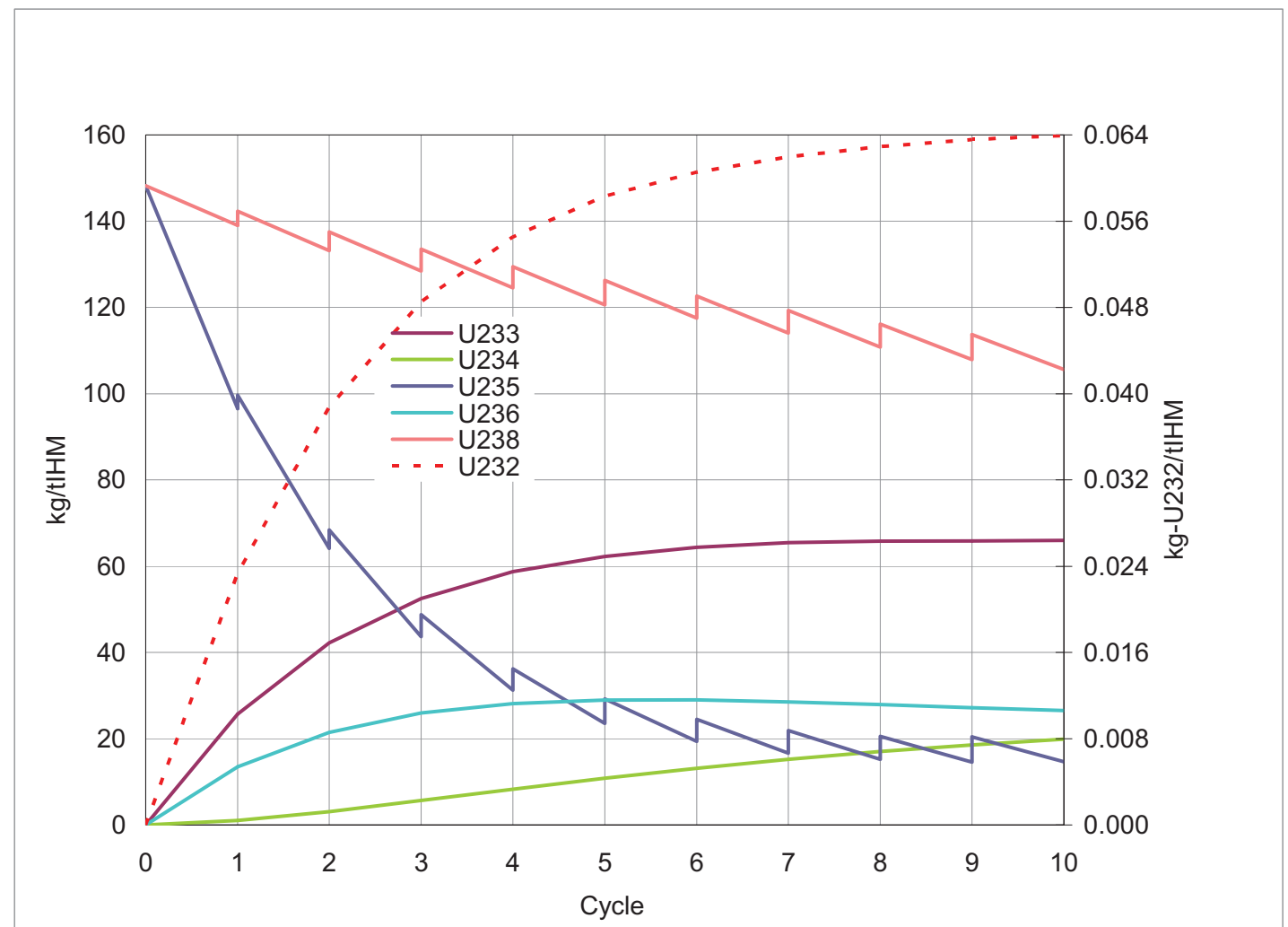

Figure B.4a. Evolution of $U$ concentration at fabrication and reprocessing of the Th-U-Pu fuel (kg/tlHM). water-to-fuel volume ratio $=0.6$. Burnup $=45,000 \mathrm{GWd} / \mathrm{t}_{\text {нМ }}$. U\&Pu are recycled.

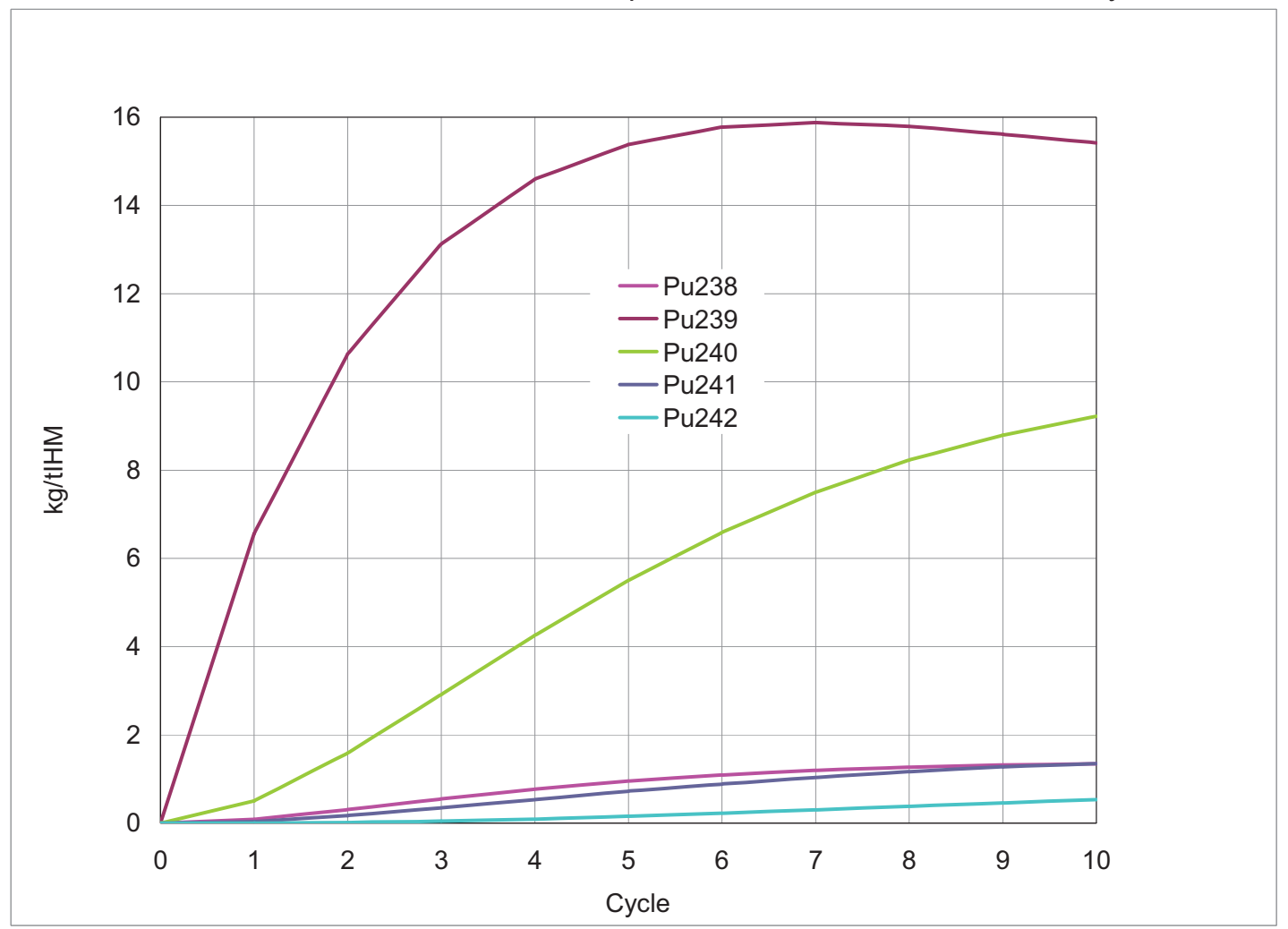

Figure B.4b. Evolution of Pu concentration at fabrication and reprocessing of the Th-U-Pu fuel (kg/tlHM). water-to-fuel volume ratio $=0.6$. Burnup $=45,000 \mathrm{GWd} / \mathrm{t}_{\mathrm{HM}}$. U\&Pu are recycled. 


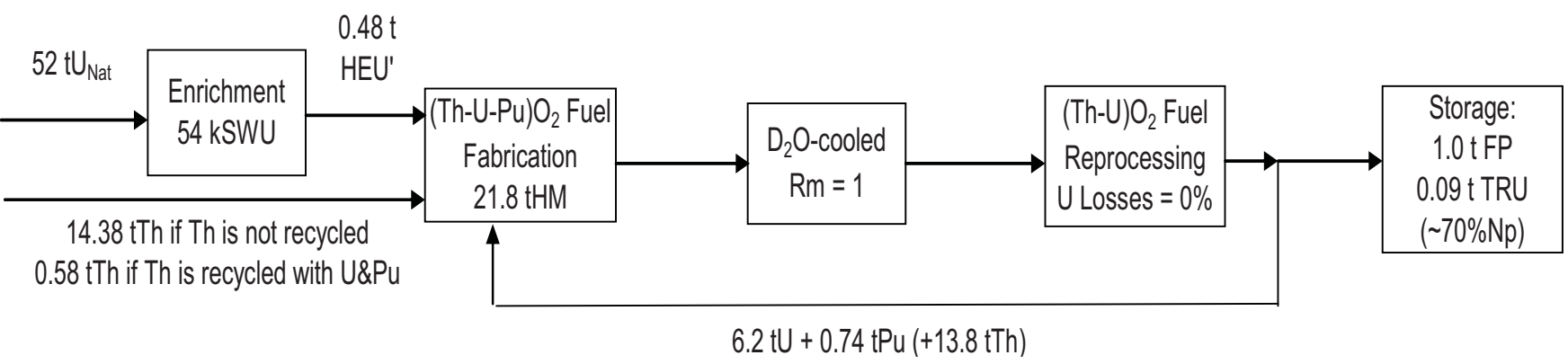

(a)

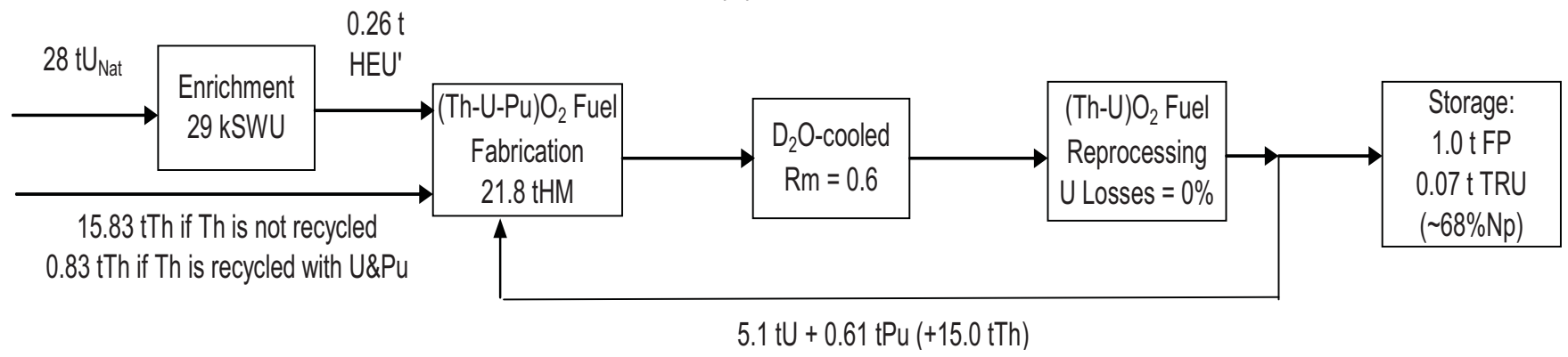

(b)

Figure B.5. Static equilibrium annual mass flows for $1 \mathrm{GWe}$ heavy-water-cooled Thorium reactors with water-to-fuel volume ratio of 1 (a) and 0.6 (b). Burnup $=45,000 \mathrm{MWd} / \mathrm{t}_{\mathrm{HM}}$. Energy $=8 \mathrm{TWhe}$. U\&Pu are recycled. 
Improving Natural Uranium Utilization by Using Thorium in Low Moderation PWRs

Table B.3. Heavy-water-to-fuel volume ratio $=1-45,000 \mathrm{MWd} / \mathrm{t}-\mathrm{Th}-\mathrm{U}-\mathrm{Pu}$ fuel -5 years after discharge

\begin{tabular}{|c|c|c|c|c|c|c|c|c|c|c|c|}
\hline $\mathrm{kg} / \mathrm{tlHM}$ & UO2 & Repro. 1 & Repro. 2 & Repro. 3 & Repro. 4 & Repro. 5 & Repro. 6 & Repro. 7 & Repro. 8 & Repro. 9 & Repro. 10 \\
\hline $\mathrm{Pa} 231$ & 0 & 1.4E-01 & 1.4E-01 & $1.4 \mathrm{E}-01$ & $1.4 \mathrm{E}-01$ & $1.4 \mathrm{E}-01$ & 1.4E-01 & $1.4 \mathrm{E}-01$ & $1.4 \mathrm{E}-01$ & $1.4 \mathrm{E}-01$ & $1.4 \mathrm{E}-01$ \\
\hline Np237 & $6.3 \mathrm{E}-01$ & $7.8 \mathrm{E}-01$ & $1.6 \mathrm{E}+00$ & $2.1 \mathrm{E}+00$ & $2.4 \mathrm{E}+00$ & $2.6 \mathrm{E}+00$ & $2.7 \mathrm{E}+00$ & $2.8 \mathrm{E}+00$ & $2.8 \mathrm{E}+00$ & $2.8 \mathrm{E}+00$ & $2.8 \mathrm{E}+00$ \\
\hline Pu238 & 2.9E-01 & 0 & 0 & 0 & 0 & 0 & 0 & 0 & 0 & 0 & 0 \\
\hline Pu239 & $6.2 \mathrm{E}+00$ & 0 & 0 & 0 & 0 & 0 & 0 & 0 & 0 & 0 & 0 \\
\hline Pu240 & $2.9 \mathrm{E}+00$ & 0 & 0 & 0 & 0 & 0 & 0 & 0 & 0 & 0 & 0 \\
\hline Pu241 & $1.1 \mathrm{E}+00$ & 0 & 0 & 0 & 0 & 0 & 0 & 0 & 0 & 0 & 0 \\
\hline Pu242 & 8.6E-01 & 0 & 0 & 0 & 0 & 0 & 0 & 0 & 0 & 0 & 0 \\
\hline Am241 & 7.3E-01 & $3.9 \mathrm{E}-02$ & $9.9 \mathrm{E}-02$ & 2.1E-01 & 3.3E-01 & 4.5E-01 & 5.7E-01 & $6.8 \mathrm{E}-01$ & $7.8 \mathrm{E}-01$ & 8.5E-01 & $9.2 \mathrm{E}-01$ \\
\hline Am242m & $8.2 \mathrm{E}-04$ & 5.7E-05 & $5.8 \mathrm{E}-04$ & 1.7E-03 & $2.9 \mathrm{E}-03$ & $4.2 \mathrm{E}-03$ & $5.5 \mathrm{E}-03$ & $6.8 \mathrm{E}-03$ & 7.9E-03 & 8.7E-03 & $9.5 \mathrm{E}-03$ \\
\hline Am243 & 2.0E-01 & $2.2 \mathrm{E}-04$ & $2.6 \mathrm{E}-03$ & $9.4 \mathrm{E}-03$ & $2.0 \mathrm{E}-02$ & 3.6E-02 & $5.6 \mathrm{E}-02$ & $7.8 \mathrm{E}-02$ & 1.0E-01 & $1.2 \mathrm{E}-01$ & $1.4 \mathrm{E}-01$ \\
\hline $\mathrm{Cm} 242$ & $2.0 \mathrm{E}-06$ & $1.5 \mathrm{E}-07$ & $2.0 \mathrm{E}-06$ & $5.6 \mathrm{E}-06$ & 9.7E-06 & $1.4 \mathrm{E}-05$ & 1.9E-05 & $2.3 \mathrm{E}-05$ & 2.7E-05 & $2.9 \mathrm{E}-05$ & $3.2 \mathrm{E}-05$ \\
\hline $\mathrm{Cm} 243$ & $6.0 \mathrm{E}-04$ & 3.3E-06 & 4.6E-05 & $1.4 \mathrm{E}-04$ & $2.4 \mathrm{E}-04$ & $3.6 \mathrm{E}-04$ & $4.9 \mathrm{E}-04$ & $6.0 \mathrm{E}-04$ & 7.1E-04 & $7.8 \mathrm{E}-04$ & 8.5E-04 \\
\hline $\mathrm{Cm} 244$ & $5.9 \mathrm{E}-02$ & $1.3 \mathrm{E}-05$ & $3.0 \mathrm{E}-04$ & $1.2 \mathrm{E}-03$ & $2.9 \mathrm{E}-03$ & 5.4E-03 & $8.6 \mathrm{E}-03$ & $1.2 \mathrm{E}-02$ & $1.6 \mathrm{E}-02$ & $1.9 \mathrm{E}-02$ & 2.3E-02 \\
\hline $\mathrm{Cm} 245$ & 5.7E-03 & 8.7E-07 & $2.8 \mathrm{E}-05$ & $1.3 \mathrm{E}-04$ & $3.1 \mathrm{E}-04$ & $6.2 \mathrm{E}-04$ & 1.0E-03 & $1.5 \mathrm{E}-03$ & 2.1E-03 & $2.4 \mathrm{E}-03$ & $3.0 \mathrm{E}-03$ \\
\hline $\mathrm{Cm} 246$ & 7.3E-04 & $1.2 \mathrm{E}-08$ & $6.2 \mathrm{E}-07$ & $3.1 \mathrm{E}-06$ & $7.8 \mathrm{E}-06$ & $1.6 \mathrm{E}-05$ & 2.7E-05 & 4.0E-05 & 5.4E-05 & $6.3 \mathrm{E}-05$ & $7.8 \mathrm{E}-05$ \\
\hline $\mathrm{Cm} 247$ & 1.0E-05 & 1.7E-10 & $1.4 \mathrm{E}-08$ & $7.4 \mathrm{E}-08$ & $1.9 \mathrm{E}-07$ & 3.9E-07 & $6.6 \mathrm{E}-07$ & $9.8 \mathrm{E}-07$ & $1.3 \mathrm{E}-06$ & $1.6 \mathrm{E}-06$ & 1.9E-06 \\
\hline $\mathrm{Cm} 248$ & 7.7E-07 & 3.1E-12 & $3.6 \mathrm{E}-10$ & 2.0E-09 & $5.2 \mathrm{E}-09$ & $1.1 \mathrm{E}-08$ & $1.9 \mathrm{E}-08$ & $2.9 \mathrm{E}-08$ & $3.9 \mathrm{E}-08$ & $4.5 \mathrm{E}-08$ & 5.7E-08 \\
\hline $\mathrm{Pa}$ & $0.0 \mathrm{E}+00$ & 1.4E-01 & 1.4E-01 & 1.4E-01 & $1.4 \mathrm{E}-01$ & $1.4 \mathrm{E}-01$ & 1.4E-01 & $1.4 \mathrm{E}-01$ & 1.4E-01 & $1.4 \mathrm{E}-01$ & $1.4 \mathrm{E}-01$ \\
\hline $\mathrm{Np}$ & $6.3 \mathrm{E}-01$ & 7.8E-01 & $1.6 \mathrm{E}+00$ & $2.1 E+00$ & $2.4 \mathrm{E}+00$ & $2.6 \mathrm{E}+00$ & 2.7E+00 & $2.8 \mathrm{E}+00$ & $2.8 \mathrm{E}+00$ & $2.8 \mathrm{E}+00$ & $2.8 \mathrm{E}+00$ \\
\hline $\mathrm{Pu}$ & $1.1 \mathrm{E}+01$ & $0.0 \mathrm{E}+00$ & $0.0 \mathrm{E}+00$ & $0.0 \mathrm{E}+00$ & $0.0 \mathrm{E}+00$ & $0.0 \mathrm{E}+00$ & $0.0 \mathrm{E}+00$ & $0.0 \mathrm{E}+00$ & $0.0 \mathrm{E}+00$ & $0.0 \mathrm{E}+00$ & $0.0 \mathrm{E}+00$ \\
\hline Am & 9.3E-01 & 3.9E-02 & $1.0 \mathrm{E}-01$ & $2.2 \mathrm{E}-01$ & 3.5E-01 & 4.9E-01 & $6.3 \mathrm{E}-01$ & 7.7E-01 & 8.9E-01 & $9.8 \mathrm{E}-01$ & $1.1 \mathrm{E}+00$ \\
\hline $\mathrm{Cm}$ & 6.6E-02 & 1.7E-05 & 3.7E-04 & $1.5 \mathrm{E}-03$ & $3.4 \mathrm{E}-03$ & $6.4 \mathrm{E}-03$ & $1.0 \mathrm{E}-02$ & $1.4 \mathrm{E}-02$ & 1.9E-02 & $2.2 \mathrm{E}-02$ & 2.7E-02 \\
\hline Total & $1.3 E+01$ & 9.6E-01 & $1.9 \mathrm{E}+00$ & $2.5 E+00$ & $2.9 \mathrm{E}+00$ & $3.3 E+00$ & $3.5 E+00$ & 3.7E+00 & $3.8 \mathrm{E}+00$ & $4.0 \mathrm{E}+00$ & $4.1 E+00$ \\
\hline
\end{tabular}

Table B.4. Heavy-water-to-fuel volume ratio $=0.6-45,000 \mathrm{MWd} / \mathrm{t}-\mathrm{Th}-\mathrm{U}-\mathrm{Pu}$ fuel $\mathbf{-} 5$ years after discharge

\begin{tabular}{|c|c|c|c|c|c|c|c|c|c|c|c|}
\hline $\mathrm{kg} / \mathrm{tlHM}$ & UO2 & Repro. 1 & Repro. 2 & Repro. 3 & Repro. 4 & Repro. 5 & Repro. 6 & Repro. 7 & Repro. 8 & Repro. 9 & Repro. 10 \\
\hline $\mathrm{Pa} 231$ & 0 & 1.6E-01 & 1.7E-01 & 1.7E-01 & 1.7E-01 & 1.7E-01 & 1.7E-01 & 1.7E-01 & 1.7E-01 & 1.7E-01 & 1.7E-01 \\
\hline Np237 & $6.3 \mathrm{E}-01$ & 7.1E-01 & $1.5 \mathrm{E}+00$ & $1.9 \mathrm{E}+00$ & $2.2 \mathrm{E}+00$ & $2.3 E+00$ & $2.3 E+00$ & $2.3 \mathrm{E}+00$ & $2.3 \mathrm{E}+00$ & $2.2 \mathrm{E}+00$ & $2.2 \mathrm{E}+00$ \\
\hline Pu238 & $2.9 \mathrm{E}-01$ & 0 & 0 & 0 & 0 & 0 & 0 & 0 & 0 & 0 & 0 \\
\hline Pu239 & $6.2 \mathrm{E}+00$ & 0 & 0 & 0 & 0 & 0 & 0 & 0 & 0 & 0 & 0 \\
\hline Pu240 & $2.9 \mathrm{E}+00$ & 0 & 0 & 0 & 0 & 0 & 0 & 0 & 0 & 0 & 0 \\
\hline Pu241 & $1.1 \mathrm{E}+00$ & 0 & 0 & 0 & 0 & 0 & 0 & 0 & 0 & 0 & 0 \\
\hline Pu242 & 8.6E-01 & 0 & 0 & 0 & 0 & 0 & 0 & 0 & 0 & 0 & 0 \\
\hline Am241 & 7.3E-01 & $2.8 \mathrm{E}-02$ & 7.7E-02 & 1.7E-01 & 2.7E-01 & $3.8 \mathrm{E}-01$ & 4.7E-01 & 5.6E-01 & $6.4 \mathrm{E}-01$ & 7.0E-01 & 7.4E-01 \\
\hline Am $242 m$ & $8.2 \mathrm{E}-04$ & $4.5 \mathrm{E}-05$ & 4.7E-04 & $1.4 \mathrm{E}-03$ & $2.5 \mathrm{E}-03$ & 3.7E-03 & $4.8 \mathrm{E}-03$ & $5.8 \mathrm{E}-03$ & 6.7E-03 & $7.5 \mathrm{E}-03$ & 8.1E-03 \\
\hline Am243 & $2.0 \mathrm{E}-01$ & $1.2 \mathrm{E}-04$ & $1.5 \mathrm{E}-03$ & $5.8 \mathrm{E}-03$ & $1.3 \mathrm{E}-02$ & $2.4 \mathrm{E}-02$ & 3.7E-02 & $5.1 \mathrm{E}-02$ & 6.7E-02 & $8.2 \mathrm{E}-02$ & $9.5 \mathrm{E}-02$ \\
\hline $\mathrm{Cm} 242$ & $2.0 \mathrm{E}-06$ & $1.2 \mathrm{E}-07$ & $1.6 \mathrm{E}-06$ & 4.6E-06 & 8.2E-06 & $1.2 \mathrm{E}-05$ & $1.6 \mathrm{E}-05$ & $1.9 \mathrm{E}-05$ & $2.2 \mathrm{E}-05$ & $2.5 \mathrm{E}-05$ & $2.6 \mathrm{E}-05$ \\
\hline $\mathrm{Cm} 243$ & $6.0 \mathrm{E}-04$ & $2.2 \mathrm{E}-06$ & 3.0E-05 & $9.4 \mathrm{E}-05$ & 1.7E-04 & $2.6 \mathrm{E}-04$ & $3.5 \mathrm{E}-04$ & $4.2 \mathrm{E}-04$ & 5.0E-04 & $5.6 \mathrm{E}-04$ & $6.0 \mathrm{E}-04$ \\
\hline $\mathrm{Cm} 244$ & $5.9 \mathrm{E}-02$ & $6.3 \mathrm{E}-06$ & $1.6 \mathrm{E}-04$ & 7.1E-04 & 1.7E-03 & $3.4 \mathrm{E}-03$ & $5.2 \mathrm{E}-03$ & 7.5E-03 & $9.9 \mathrm{E}-03$ & $1.2 \mathrm{E}-02$ & $1.4 \mathrm{E}-02$ \\
\hline $\mathrm{Cm} 245$ & 5.7E-03 & $3.9 \mathrm{E}-07$ & $1.3 \mathrm{E}-05$ & $6.5 \mathrm{E}-05$ & 1.7E-04 & $3.5 \mathrm{E}-04$ & $5.5 \mathrm{E}-04$ & $8.2 \mathrm{E}-04$ & 1.1E-03 & $1.5 \mathrm{E}-03$ & 1.7E-03 \\
\hline $\mathrm{Cm} 246$ & 7.3E-04 & 5.2E-09 & $2.9 \mathrm{E}-07$ & 1.6E-06 & 4.4E-06 & 9.3E-06 & $1.5 \mathrm{E}-05$ & $2.2 \mathrm{E}-05$ & 3.1E-05 & 4.0E-05 & 4.6E-05 \\
\hline $\mathrm{Cm} 247$ & $1.0 \mathrm{E}-05$ & 7.4E-11 & 6.4E-09 & $3.8 \mathrm{E}-08$ & 1.1E-07 & 2.3E-07 & 3.7E-07 & $5.6 \mathrm{E}-07$ & 7.7E-07 & 1.0E-06 & $1.2 \mathrm{E}-06$ \\
\hline $\mathrm{Cm} 248$ & 7.7E-07 & $1.2 \mathrm{E}-12$ & $1.6 \mathrm{E}-10$ & 9.7E-10 & 2.8E-09 & 6.1E-09 & $9.8 \mathrm{E}-09$ & 1.5E-08 & $2.2 \mathrm{E}-08$ & $2.8 \mathrm{E}-08$ & 3.3E-08 \\
\hline $\mathrm{Pa}$ & $0.0 \mathrm{E}+00$ & $1.6 \mathrm{E}-01$ & 1.7E-01 & 1.7E-01 & 1.7E-01 & 1.7E-01 & 1.7E-01 & 1.7E-01 & 1.7E-01 & 1.7E-01 & 1.7E-01 \\
\hline $\mathrm{Np}$ & $6.3 \mathrm{E}-01$ & 7.1E-01 & $1.5 E+00$ & $1.9 \mathrm{E}+00$ & $2.2 \mathrm{E}+00$ & $2.3 E+00$ & $2.3 E+00$ & $2.3 \mathrm{E}+00$ & $2.3 \mathrm{E}+00$ & $2.2 \mathrm{E}+00$ & $2.2 \mathrm{E}+00$ \\
\hline $\mathrm{Pu}$ & $1.1 \mathrm{E}+01$ & $0.0 \mathrm{E}+00$ & $0.0 \mathrm{E}+00$ & $0.0 \mathrm{E}+00$ & $0.0 \mathrm{E}+00$ & $0.0 \mathrm{E}+00$ & $0.0 \mathrm{E}+00$ & $0.0 \mathrm{E}+00$ & $0.0 \mathrm{E}+00$ & $0.0 \mathrm{E}+00$ & $0.0 \mathrm{E}+00$ \\
\hline Am & 9.3E-01 & $2.8 \mathrm{E}-02$ & 7.9E-02 & $1.8 \mathrm{E}-01$ & 2.9E-01 & 4.1E-01 & $5.2 \mathrm{E}-01$ & $6.2 \mathrm{E}-01$ & 7.1E-01 & 7.9E-01 & 8.5E-01 \\
\hline $\mathrm{Cm}$ & $6.6 \mathrm{E}-02$ & $9.0 \mathrm{E}-06$ & $2.0 \mathrm{E}-04$ & 8.7E-04 & 2.1E-03 & 4.0E-03 & 6.1E-03 & 8.7E-03 & $1.2 \mathrm{E}-02$ & $1.5 \mathrm{E}-02$ & 1.7E-02 \\
\hline Total & $1.3 E+01$ & 9.0E-01 & $1.7 \mathrm{E}+00$ & $2.3 E+00$ & $2.6 \mathrm{E}+00$ & $2.9 \mathrm{E}+00$ & $3.0 \mathrm{E}+00$ & $3.1 E+00$ & $3.2 \mathrm{E}+00$ & $3.2 \mathrm{E}+00$ & $3.2 E+00$ \\
\hline
\end{tabular}




\section{Appendix C}

Details of TRU + Pa that needs to be disposed of $(\underline{\mathrm{kg} / \mathrm{tl} \mathrm{HM}})$ for the different fuels, coolants (light or heavy water) and water-to-fuel volume ratios.

The amount of TRU in a reference $\mathrm{UO}_{2}$ spent fuel irradiated up to 51,000 $\mathrm{MWd} / \mathrm{t}$ is presented for comparison. 
Improving Natural Uranium Utilization by Using Thorium in Low Moderation PWRs

Table C.1. Light-water-to-fuel volume ratio $=2-45,000 \mathrm{MWd} / \mathrm{t}-\mathrm{Th}-\mathrm{U}$ fuel -10 years after discharge

\begin{tabular}{|c|c|c|c|c|c|c|c|c|c|c|c|}
\hline $\mathrm{kg} / \mathrm{tIHM}$ & UO2 & Repro. 1 & Repro. 2 & Repro. 3 & Repro. 4 & Repro. 5 & Repro. 6 & Repro. 7 & Repro. 8 & Repro. 9 & Repro. 10 \\
\hline $\mathrm{Pa} 231$ & 0 & $7.2 \mathrm{E}-02$ & $7.3 \mathrm{E}-02$ & $7.4 \mathrm{E}-02$ & $7.5 \mathrm{E}-02$ & $7.5 \mathrm{E}-02$ & $7.6 \mathrm{E}-02$ & $7.6 \mathrm{E}-02$ & $7.6 \mathrm{E}-02$ & $7.6 \mathrm{E}-02$ & $7.6 \mathrm{E}-02$ \\
\hline Np237 & $6.3 \mathrm{E}-01$ & $5.4 \mathrm{E}-01$ & $8.8 \mathrm{E}-01$ & $1.1 \mathrm{E}+00$ & $1.2 \mathrm{E}+00$ & $1.3 \mathrm{E}+00$ & $1.5 \mathrm{E}+00$ & $1.6 \mathrm{E}+00$ & $1.7 \mathrm{E}+00$ & $1.8 \mathrm{E}+00$ & $1.8 \mathrm{E}+00$ \\
\hline Pu238 & $2.9 \mathrm{E}-01$ & 1.7E-01 & $3.2 \mathrm{E}-01$ & 3.9E-01 & 4.4E-01 & 4.9E-01 & 5.3E-01 & 5.7E-01 & $6.0 \mathrm{E}-01$ & $6.3 \mathrm{E}-01$ & $6.6 \mathrm{E}-01$ \\
\hline Pu239 & $6.2 E+00$ & 1.6E-01 & $2.2 \mathrm{E}-01$ & 2.6E-01 & 3.0E-01 & 3.3E-01 & 3.6E-01 & $3.8 \mathrm{E}-01$ & 4.0E-01 & 4.2E-01 & 4.4E-01 \\
\hline Pu240 & $2.9 \mathrm{E}+00$ & 5.1E-02 & $6.9 \mathrm{E}-02$ & 8.2E-02 & $9.2 \mathrm{E}-02$ & $1.0 \mathrm{E}-01$ & 1.1E-01 & $1.2 \mathrm{E}-01$ & $1.2 \mathrm{E}-01$ & $1.3 \mathrm{E}-01$ & $1.3 \mathrm{E}-01$ \\
\hline Pu241 & $1.1 \mathrm{E}+00$ & $3.6 \mathrm{E}-02$ & 4.7E-02 & $5.6 \mathrm{E}-02$ & $6.3 \mathrm{E}-02$ & $6.9 \mathrm{E}-02$ & 7.4E-02 & 7.9E-02 & 8.3E-02 & 8.7E-02 & $9.0 \mathrm{E}-02$ \\
\hline Pu242 & 8.6E-01 & $3.5 \mathrm{E}-02$ & 4.3E-02 & $4.9 \mathrm{E}-02$ & $5.3 \mathrm{E}-02$ & 5.6E-02 & $5.9 \mathrm{E}-02$ & $6.1 \mathrm{E}-02$ & $6.3 \mathrm{E}-02$ & $6.5 \mathrm{E}-02$ & 6.7E-02 \\
\hline Am241 & 7.3E-01 & $2.4 \mathrm{E}-02$ & $3.2 \mathrm{E}-02$ & 3.7E-02 & $4.2 \mathrm{E}-02$ & 4.6E-02 & $5.0 \mathrm{E}-02$ & $5.3 \mathrm{E}-02$ & 5.6E-02 & $5.8 \mathrm{E}-02$ & $6.0 \mathrm{E}-02$ \\
\hline Am242m & $8.2 \mathrm{E}-04$ & 2.7E-05 & $3.4 \mathrm{E}-05$ & 4.1E-05 & $4.8 \mathrm{E}-05$ & 5.3E-05 & 5.7E-05 & $6.1 \mathrm{E}-05$ & $6.5 \mathrm{E}-05$ & $6.8 \mathrm{E}-05$ & 7.1E-05 \\
\hline Am243 & 2.0E-01 & $9.2 \mathrm{E}-03$ & $1.1 \mathrm{E}-02$ & 2 & 1.3 & 1.4E-02 & $1.4 \mathrm{E}-02$ & -02 & -02 & $1.5 \mathrm{E}-02$ & $\mathrm{E}-02$ \\
\hline $\mathrm{Cm} 242$ & $2.0 \mathrm{E}-06$ & 7.0E-08 & 08 & $\mathrm{E}-07$ & $1.2 \mathrm{E}-07$ & 1.4E-07 & $1.5 \mathrm{E}-07$ & $1.6 \mathrm{E}-07$ & 1.7E-07 & $1.8 \mathrm{E}-07$ & $8 \mathrm{E}-07$ \\
\hline $\mathrm{Cm} 243$ & $6.0 \mathrm{E}-04$ & $1.8 \mathrm{E}-05$ & 2.1E-05 & $2.4 \mathrm{E}-05$ & $2.6 \mathrm{E}-05$ & $2.8 \mathrm{E}-05$ & $2.9 \mathrm{E}-05$ & $3.0 \mathrm{E}-05$ & 3.1E-05 & $3.2 \mathrm{E}-05$ & $3.3 \mathrm{E}-05$ \\
\hline $\mathrm{Cm} 244$ & $5.9 \mathrm{E}-02$ & $2.2 \mathrm{E}-03$ & $2.5 \mathrm{E}-03$ & 2.7E-03 & $2.8 \mathrm{E}-03$ & $2.9 \mathrm{E}-03$ & 3.0E-03 & $3.0 \mathrm{E}-03$ & 3.1E-03 & $3.2 \mathrm{E}-03$ & $3.2 \mathrm{E}-03$ \\
\hline $\mathrm{Cm} 245$ & 5.7E-03 & $2.0 \mathrm{E}-04$ & $2.2 \mathrm{E}-04$ & $2.4 \mathrm{E}-04$ & $2.5 \mathrm{E}-04$ & 2.6E-04 & 2.7E-04 & -04 & 04 & -04 & -04 \\
\hline $\mathrm{Cm} 246$ & 7.3E-04 & $2.4 \mathrm{E}-05$ & $2.5 \mathrm{E}-05$ & $2.6 \mathrm{E}-05$ & 2.7E-05 & 2.7E-05 & 2.7E-05 & 2.7E-05 & -05 & $2.8 \mathrm{E}-05$ & -05 \\
\hline $\mathrm{Cm} 247$ & $1.0 \mathrm{E}-05$ & $3.0 \mathrm{E}-07$ & 3.0E-07 & $3.1 \mathrm{E}-07$ & 3.1E-07 & $3.1 \mathrm{E}-07$ & $3.1 \mathrm{E}-07$ & $3.1 \mathrm{E}-07$ & 3.1E-07 & $3.1 \mathrm{E}-07$ & $3.1 \mathrm{E}-07$ \\
\hline $\mathrm{Cm} 248$ & 7.7E-07 & $2.1 \mathrm{E}-08$ & $2.1 \mathrm{E}-08$ & $2.1 \mathrm{E}-08$ & $2.0 \mathrm{E}-08$ & 2.0E-08 & -08 & -08 & -08 & -08 & -08 \\
\hline $\mathrm{Pa}$ & $0.0 \mathrm{E}+00$ & $7.2 \mathrm{E}-02$ & 7.3E-02 & $7.4 \mathrm{E}-02$ & 7.5E-02 & 7.5E-02 & 7.6E-02 & 7.6E-02 & $7.6 \mathrm{E}-02$ & 7.6E-02 & 7.6E-02 \\
\hline Np & $6.3 \mathrm{E}-01$ & $5.4 \mathrm{E}-01$ & 8.8E-01 & $1.1 \mathrm{E}+00$ & $1.2 \mathrm{E}+00$ & $1.3 \mathrm{E}+00$ & $1.5 \mathrm{E}+00$ & $1.6 \mathrm{E}+00$ & 1.7E+00 & $1.8 \mathrm{E}+00$ & $1.8 \mathrm{E}+00$ \\
\hline $\mathrm{Pu}$ & $1.1 \mathrm{E}+01$ & $4.5 \mathrm{E}-01$ & 7.0E-01 & 8.4E-01 & $9.5 \mathrm{E}-01$ & $1.0 \mathrm{E}+00$ & $1.1 \mathrm{E}+00$ & $1.2 \mathrm{E}+00$ & $1.3 \mathrm{E}+00$ & $1.3 \mathrm{E}+00$ & $1.4 \mathrm{E}+00$ \\
\hline $\mathrm{Am}$ & $9.3 \mathrm{E}-01$ & 3.3E-02 & $4.2 \mathrm{E}-02$ & 4.9E-02 & 5.5E-02 & $6.0 \mathrm{E}-02$ & $6.4 \mathrm{E}-02$ & 6.7E-02 & 7.1E-02 & 7.3E-02 & 7.6E-02 \\
\hline $\mathrm{Cm}$ & $6.6 \mathrm{E}-02$ & $2.5 \mathrm{E}-03$ & 2.7E-03 & $2.9 \mathrm{E}-03$ & 3.1E-03 & $3.2 \mathrm{E}-03$ & $3.3 \mathrm{E}-03$ & $3.4 \mathrm{E}-03$ & $3.4 \mathrm{E}-03$ & $3.5 \mathrm{E}-03$ & $3.6 \mathrm{E}-03$ \\
\hline Total & $1.3 E+01$ & $1.1 E+00$ & 1.7E+00 & $2.0 \mathrm{E}+00$ & $2.3 E+00$ & $2.5 E+00$ & 2.7E+00 & $2.9 E+00$ & $3.1 \mathrm{E}+00$ & $3.2 \mathrm{E}+00$ & $3.4 \mathrm{E}+00$ \\
\hline
\end{tabular}

Table C.2. Light-water-to-fuel volume ratio = $1-45,000 \mathrm{MWd} / \mathrm{t}-\mathrm{Th}-\mathrm{U}$ fuel -10 years after discharge

\begin{tabular}{|c|c|c|c|c|c|c|c|c|c|c|c|}
\hline $\mathrm{kg} / \mathrm{tlHM}$ & UO2 & Repro. 1 & Repro. 2 & Repro. 3 & Repro. 4 & Repro. 5 & Repro. 6 & Repro. 7 & Repro. 8 & Repro. 9 & Repro. 10 \\
\hline Pa231 & 0 & $1.0 \mathrm{E}-01$ & $1.0 \mathrm{E}-01$ & 1.1E-01 & $1.1 \mathrm{E}-01$ & $1.1 \mathrm{E}-01$ & $1.1 \mathrm{E}-01$ & $1.1 \mathrm{E}-01$ & $1.1 \mathrm{E}-01$ & 1.1E-01 & $1.1 \mathrm{E}-01$ \\
\hline Np237 & $6.3 \mathrm{E}-01$ & $8.2 \mathrm{E}-01$ & $1.3 \mathrm{E}+00$ & $1.5 \mathrm{E}+00$ & $1.7 \mathrm{E}+00$ & $1.8 \mathrm{E}+00$ & $2.0 \mathrm{E}+00$ & $2.1 \mathrm{E}+00$ & $2.2 \mathrm{E}+00$ & $2.3 \mathrm{E}+00$ & $2.4 \mathrm{E}+00$ \\
\hline Pu238 & $2.9 \mathrm{E}-01$ & 3.0E-01 & $5.5 \mathrm{E}-01$ & $6.4 \mathrm{E}-01$ & 7.0E-01 & 7.5E-01 & 8.0E-01 & $8.4 \mathrm{E}-01$ & 8.8E-01 & 9.1E-01 & $9.4 \mathrm{E}-01$ \\
\hline Pu239 & $6.2 E+00$ & 3.6E-01 & 4.2E-01 & 4.7E-01 & 5.1E-01 & $5.5 \mathrm{E}-01$ & $5.8 \mathrm{E}-01$ & $6.1 \mathrm{E}-01$ & $6.3 \mathrm{E}-01$ & $6.6 \mathrm{E}-01$ & $6.8 \mathrm{E}-01$ \\
\hline Pu240 & $2.9 \mathrm{E}+00$ & 7.4E-02 & 8.6E-02 & $9.5 \mathrm{E}-02$ & 1.0E-01 & 1.1E-01 & 1.1E-01 & $1.2 \mathrm{E}-01$ & $1.2 \mathrm{E}-01$ & $1.2 \mathrm{E}-01$ & $1.3 \mathrm{E}-01$ \\
\hline Pu241 & $1.1 \mathrm{E}+00$ & 7.9E-02 & 8.6E-02 & $9.3 \mathrm{E}-02$ & 9.9E-02 & 1.0E-01 & 1.1E-01 & 1.1E-01 & 1.1E-01 & 1.2E-01 & $1.2 \mathrm{E}-01$ \\
\hline Pu242 & 8.6E-01 & 4.0E-02 & 4.2E-02 & 4.3E-02 & 4.3E-02 & 4.3E-02 & $4.4 \mathrm{E}-02$ & $4.4 \mathrm{E}-02$ & 4.4E-02 & 4.4E-02 & 4.4E-02 \\
\hline Am241 & 7.3E-01 & $5.5 \mathrm{E}-02$ & $6.0 \mathrm{E}-02$ & $6.5 \mathrm{E}-02$ & $6.9 \mathrm{E}-02$ & 7.3E-02 & 7.6E-02 & $7.8 \mathrm{E}-02$ & 8.0E-02 & $8.2 \mathrm{E}-02$ & $8.4 \mathrm{E}-02$ \\
\hline Am $242 m$ & $8.2 \mathrm{E}-04$ & $1.4 \mathrm{E}-04$ & $1.4 \mathrm{E}-04$ & $1.6 \mathrm{E}-04$ & 1.7E-04 & $1.8 \mathrm{E}-04$ & $1.9 \mathrm{E}-04$ & $1.9 \mathrm{E}-04$ & 2.0E-04 & 2.0E-04 & 2.1E-04 \\
\hline Am243 & $2.0 \mathrm{E}-01$ & $1.3 \mathrm{E}-02$ & $1.3 \mathrm{E}-02$ & $1.3 \mathrm{E}-02$ & $1.3 \mathrm{E}-02$ & $1.2 \mathrm{E}-02$ & $1.2 \mathrm{E}-02$ & $1.2 \mathrm{E}-02$ & $1.2 \mathrm{E}-02$ & $1.2 \mathrm{E}-02$ & $1.2 \mathrm{E}-02$ \\
\hline $\mathrm{Cm} 242$ & $2.0 \mathrm{E}-06$ & $3.6 \mathrm{E}-07$ & 3.7E-07 & 4.1E-07 & 4.4E-07 & 4.7E-07 & $4.9 \mathrm{E}-07$ & 5.1E-07 & $5.2 \mathrm{E}-07$ & $5.3 \mathrm{E}-07$ & $5.5 E-07$ \\
\hline $\mathrm{Cm} 243$ & $6.0 \mathrm{E}-04$ & $4.4 \mathrm{E}-05$ & 4.4E-05 & 4.5E-05 & 4.6E-05 & 4.6E-05 & 4.6E-05 & 4.7E-05 & 4.7E-05 & 4.7E-05 & 4.7E-05 \\
\hline $\mathrm{Cm} 244$ & $5.9 \mathrm{E}-02$ & $3.3 \mathrm{E}-03$ & 3.0E-03 & 2.9E-03 & $2.8 \mathrm{E}-03$ & $E-03$ & $2.6 \mathrm{E}-03$ & $2.5 \mathrm{E}-03$ & $2.5 \mathrm{E}-03$ & $2.4 \mathrm{E}-03$ & $2.4 \mathrm{E}-03$ \\
\hline $\mathrm{Cm} 245$ & 5.7E-03 & 5.3E-04 & 4.7E-04 & $4.5 \mathrm{E}-04$ & 4.3E-04 & 4.1E-04 & $4.0 \mathrm{E}-04$ & $3.9 \mathrm{E}-04$ & $3.8 \mathrm{E}-04$ & 3.7E-04 & 3.7E-04 \\
\hline $\mathrm{Cm} 246$ & 7.3E-04 & $3.4 \mathrm{E}-05$ & $2.9 \mathrm{E}-05$ & 2.6E-05 & 2.4E-05 & $2.2 \mathrm{E}-05$ & $2.1 \mathrm{E}-05$ & $1.9 \mathrm{E}-05$ & 1.9E-05 & $1.8 \mathrm{E}-05$ & 1.7E-05 \\
\hline $\mathrm{Cm} 247$ & $1.0 \mathrm{E}-05$ & $6.0 \mathrm{E}-07$ & $4.9 \mathrm{E}-07$ & 4.3E-07 & $3.9 \mathrm{E}-07$ & $3.5 \mathrm{E}-07$ & $3.3 \mathrm{E}-07$ & 3.1E-07 & 2.9E-07 & $2.8 \mathrm{E}-07$ & 2.7E-07 \\
\hline $\mathrm{Cm} 248$ & 7.7E-07 & 4.6E-08 & $3.5 \mathrm{E}-08$ & 3.0E-08 & 2.6E-08 & $2.4 \mathrm{E}-08$ & $2.2 \mathrm{E}-08$ & $2.0 \mathrm{E}-08$ & $1.9 \mathrm{E}-08$ & $1.8 \mathrm{E}-08$ & 1.7E-08 \\
\hline $\mathrm{Pa}$ & $0.0 \mathrm{E}+00$ & $1.0 \mathrm{E}-01$ & $1.0 \mathrm{E}-01$ & 1.1E-01 & 1.1E-01 & 1.1E-01 & 1.1E-01 & 1.1E-01 & 1.1E-01 & 1.1E-01 & 1.1E-01 \\
\hline $\mathrm{Np}$ & $6.3 \mathrm{E}-01$ & 8.2E-01 & $1.3 E+00$ & $1.5 \mathrm{E}+00$ & $1.7 \mathrm{E}+00$ & $1.8 \mathrm{E}+00$ & $2.0 \mathrm{E}+00$ & $2.1 E+00$ & $2.2 \mathrm{E}+00$ & $2.3 E+00$ & $2.4 \mathrm{E}+00$ \\
\hline $\mathrm{Pu}$ & $1.1 \mathrm{E}+01$ & 8.5E-01 & $1.2 \mathrm{E}+00$ & $1.3 \mathrm{E}+00$ & $1.5 \mathrm{E}+00$ & $1.6 \mathrm{E}+00$ & $1.6 \mathrm{E}+00$ & 1.7E+00 & $1.8 \mathrm{E}+00$ & $1.9 \mathrm{E}+00$ & $1.9 \mathrm{E}+00$ \\
\hline Am & $9.3 \mathrm{E}-01$ & $6.8 \mathrm{E}-02$ & 7.3E-02 & 7.8E-02 & 8.2E-02 & 8.5E-02 & $8.8 \mathrm{E}-02$ & $9.0 \mathrm{E}-02$ & $9.2 \mathrm{E}-02$ & $9.4 \mathrm{E}-02$ & $9.6 \mathrm{E}-02$ \\
\hline $\mathrm{Cm}$ & $6.6 \mathrm{E}-02$ & $3.9 \mathrm{E}-03$ & $3.5 \mathrm{E}-03$ & $3.4 \mathrm{E}-03$ & 3.3E-03 & $3.2 \mathrm{E}-03$ & 3.1E-03 & $3.0 \mathrm{E}-03$ & $2.9 \mathrm{E}-03$ & 2.9E-03 & $2.8 \mathrm{E}-03$ \\
\hline Total & $1.3 E+01$ & $1.8 \mathrm{E}+00$ & 2.7E+00 & $3.0 \mathrm{E}+00$ & $3.3 E+00$ & $3.6 \mathrm{E}+00$ & $3.8 \mathrm{E}+00$ & $4.0 \mathrm{E}+00$ & $4.2 E+00$ & $4.4 \mathrm{E}+00$ & $4.5 E+00$ \\
\hline
\end{tabular}


Improving Natural Uranium Utilization by Using Thorium in Low Moderation PWRs

Table C.3. Light-water-to-fuel volume ratio $=0.6-45,000 \mathrm{MWd} / \mathrm{t}-\mathrm{Th}-\mathrm{U}$ fuel -10 years after discharge

\begin{tabular}{|c|c|c|c|c|c|c|c|c|c|c|c|}
\hline $\mathrm{kg} / \mathrm{tlHM}$ & UO2 & Repro. 1 & Repro. 2 & Repro. 3 & Repro. 4 & Repro. 5 & Repro. 6 & Repro. 7 & Repro. 8 & Repro. 9 & Repro. 10 \\
\hline $\mathrm{Pa} 231$ & 0 & 4E-01 & $4 \mathrm{E}-01$ & 5E-01 & $1.5 \mathrm{E}-01$ & $1.5 \mathrm{E}-01$ & $1.5 \mathrm{E}-01$ & $1.5 \mathrm{E}-01$ & $1.5 \mathrm{E}-01$ & $1.5 \mathrm{E}-01$ & $1.5 \mathrm{E}-01$ \\
\hline Np237 & $6.3 \mathrm{E}-01$ & $1.0 \mathrm{E}+00$ & $1.7 \mathrm{E}+00$ & $2.0 \mathrm{E}+00$ & $2.2 \mathrm{E}+00$ & $2.4 \mathrm{E}+00$ & $2.5 \mathrm{E}+00$ & $2.6 \mathrm{E}+00$ & $2.7 \mathrm{E}+00$ & $2.8 \mathrm{E}+00$ & $2.9 \mathrm{E}+00$ \\
\hline Pu238 & $2.9 \mathrm{E}-01$ & 3.0E-01 & $6.2 \mathrm{E}-01$ & 7.3E-01 & 7.8E-01 & 8.2E-01 & 8.5E-01 & $8.8 \mathrm{E}-01$ & $9.1 \mathrm{E}-01$ & $9.3 \mathrm{E}-01$ & $9.5 \mathrm{E}-01$ \\
\hline Pu239 & $6.2 \mathrm{E}+00$ & 8.7E-01 & $8.5 \mathrm{E}-01$ & 8.6E-01 & 8.8E-01 & 9.1E-01 & $9.3 \mathrm{E}-01$ & $9.6 \mathrm{E}-01$ & $9.8 \mathrm{E}-01$ & $9.9 E-01$ & $1.0 \mathrm{E}+00$ \\
\hline Pu240 & $2.9 \mathrm{E}+00$ & $1.2 \mathrm{E}-01$ & $E-01$ & BE-01 & 1.3E-01 & -01 & -01 & -01 & 01 & -01 & $E-01$ \\
\hline Pu241 & $1.1 \mathrm{E}+00$ & 1.0E-01 & 1.0E-01 & $\mathrm{E}-01$ & $1.0 \mathrm{E}-01$ & E-01 & E-01 & $\mathrm{E}-02$ & $\mathrm{E}-02$ & $\mathrm{E}-02$ & $\mathrm{E}-02$ \\
\hline Pu242 & 8.6E-01 & $2.2 \mathrm{E}-02$ & $E-02$ & $\mathrm{E}-02$ & $2.1 \mathrm{E}-02$ & $2.0 \mathrm{E}-02$ & $2.0 \mathrm{E}-02$ & $\mathrm{E}-02$ & $\mathrm{E}-02$ & $\mathrm{E}-02$ & $\mathrm{E}-02$ \\
\hline Am241 & 7.3E-01 & 7.6E-02 & 7.4E-02 & 7.3E-02 & 7.3E-02 & 7.3E-02 & 7.2E-02 & $7.2 \mathrm{E}-02$ & $7.2 \mathrm{E}-02$ & $2 \mathrm{E}-02$ & E-02 \\
\hline Am $242 m$ & $8.2 \mathrm{E}-04$ & $2.9 \mathrm{E}-04$ & $2.6 \mathrm{E}-04$ & $E-04$ & $2.5 \mathrm{E}-04$ & $2.5 \mathrm{E}-04$ & $\mathrm{E}-04$ & -04 & $2.4 \mathrm{E}-04$ & $2.4 \mathrm{E}-04$ & $\mathrm{E}-04$ \\
\hline Am243 & 2.0E-01 & $5.8 \mathrm{E}-03$ & 5.7E-03 & $5.5 \mathrm{E}-03$ & $5.2 \mathrm{E}-03$ & 4.9E-03 & 4.7E-03 & $4.5 \mathrm{E}-03$ & 4.4E-03 & $.2 \mathrm{E}-03$ & $\mathrm{E}-03$ \\
\hline $\mathrm{Cm} 242$ & $2.0 \mathrm{E}-06$ & 7.5E-07 & $6.8 \mathrm{E}-07$ & $6.6 \mathrm{E}-07$ & $6.5 \mathrm{E}-07$ & $6.4 \mathrm{E}-07$ & $\mathrm{E}-07$ & $6.3 \mathrm{E}-07$ & $6.3 \mathrm{E}-07$ & 6.2 & $\mathrm{E}-07$ \\
\hline $\mathrm{Cm} 243$ & $6.0 \mathrm{E}-04$ & $3.6 \mathrm{E}-05$ & $3.4 \mathrm{E}-05$ & $3.3 \mathrm{E}-05$ & $3.2 \mathrm{E}-05$ & $3.0 \mathrm{E}-05$ & $2.9 \mathrm{E}-05$ & $2.8 \mathrm{E}-05$ & $2.8 \mathrm{E}-05$ & 2.7E-05 & $2.6 \mathrm{E}-05$ \\
\hline $\mathrm{Cm} 244$ & $5.9 \mathrm{E}-02$ & 1.1E-03 & $9.6 \mathrm{E}-04$ & $8.9 \mathrm{E}-04$ & 8.1E-04 & 7.5E-04 & 7.0E-04 & $6.6 \mathrm{E}-04$ & $6.3 \mathrm{E}-04$ & $6.1 \mathrm{E}-04$ & $5.8 \mathrm{E}-04$ \\
\hline $\mathrm{Cm} 245$ & 5.7E-03 & 1.9E-04 & 1.7E-04 & $\mathrm{E}-04$ & 1.4E-04 & -04 & E-04 & -04 & -04 & $9.9 E-05$ & E-05 \\
\hline $\mathrm{Cm} 246$ & 7.3E-04 & 5.6E-06 & 5.0E-06 & $4.5 \mathrm{E}-06$ & 3.9E-06 & 3.5E-06 & $3.2 \mathrm{E}-06$ & $2.9 \mathrm{E}-06$ & 2.7E-06 & $2.5 \mathrm{E}-06$ & $2.4 \mathrm{E}-06$ \\
\hline $\mathrm{Cm} 247$ & $1.0 \mathrm{E}-05$ & 1.1E-07 & $9.1 \mathrm{E}-08$ & 8.1E-08 & 7.0E-08 & $6.2 \mathrm{E}-08$ & $5.5 \mathrm{E}-08$ & $5.0 \mathrm{E}-08$ & 4.6E-08 & $4.3 \mathrm{E}-08$ & 4.0E-08 \\
\hline $\mathrm{Cm} 248$ & 7.7E-07 & $6.1 \mathrm{E}-09$ & 5.0E-09 & 4.3E-09 & 3.7E-09 & 3.2E-09 & 2.7E-09 & $2.5 \mathrm{E}-09$ & $2.2 \mathrm{E}-09$ & 2.1E-09 & $1.9 \mathrm{E}-09$ \\
\hline $\mathrm{Pa}$ & $0.0 \mathrm{E}+00$ & 1.4E-01 & $1.4 \mathrm{E}-01$ & $1.5 \mathrm{E}-01$ & 1.5E-01 & $1.5 \mathrm{E}-01$ & $1.5 \mathrm{E}-01$ & $1.5 \mathrm{E}-01$ & $1.5 \mathrm{E}-01$ & $1.5 \mathrm{E}-01$ & 1.5E-01 \\
\hline $\mathrm{Np}$ & $6.3 \mathrm{E}-01$ & $1.0 \mathrm{E}+00$ & $1.7 \mathrm{E}+00$ & $2.0 \mathrm{E}+00$ & $2.2 \mathrm{E}+00$ & $2.4 \mathrm{E}+00$ & $2.5 \mathrm{E}+00$ & $2.6 \mathrm{E}+00$ & 2.7E+00 & $2.8 \mathrm{E}+00$ & $2.9 \mathrm{E}+00$ \\
\hline $\mathrm{Pu}$ & $1.1 \mathrm{E}+01$ & $1.4 \mathrm{E}+00$ & 1.7E+00 & $1.8 \mathrm{E}+00$ & $1.9 \mathrm{E}+00$ & $2.0 \mathrm{E}+00$ & $2.0 \mathrm{E}+00$ & $2.1 E+00$ & $2.1 E+00$ & $2.2 \mathrm{E}+00$ & $2.2 \mathrm{E}+00$ \\
\hline Am & $9.3 \mathrm{E}-01$ & $8.2 \mathrm{E}-02$ & 8.0E-02 & 7.9E-02 & 7.8E-02 & $7.8 \mathrm{E}-02$ & 7.7E-02 & 7.7E-02 & 7.7E-02 & 7.6E-02 & 7.6E-02 \\
\hline $\mathrm{Cm}$ & $6.6 \mathrm{E}-02$ & $1.3 \mathrm{E}-03$ & $1.2 \mathrm{E}-03$ & $1.1 \mathrm{E}-03$ & 9.9E-04 & 9.2E-04 & 8.5E-04 & 8.1E-04 & 7.7E-04 & 7.3E-04 & 7.1E-04 \\
\hline Total & $1.3 \mathrm{E}+01$ & 2.7E+00 & $3.7 \mathrm{E}+00$ & $4.1 \mathrm{E}+00$ & $4.4 \mathrm{E}+00$ & $4.6 \mathrm{E}+00$ & 4.7E+00 & $4.9 \mathrm{E}+00$ & $5.1 \mathrm{E}+00$ & $5.2 \mathrm{E}+00$ & $5.4 \mathrm{E}+00$ \\
\hline
\end{tabular}

Table C.4. Heavy-water-to-fuel volume ratio $=2-45,000 \mathrm{MWd} / \mathrm{t}-\mathrm{Th}-\mathrm{U}$ fuel -10 years after discharge

\begin{tabular}{|c|c|c|c|c|c|c|c|c|c|c|c|}
\hline $\mathrm{kg} / \mathrm{tlHM}$ & UO2 & Repro. 1 & Repro. 2 & Repro. 3 & Repro. 4 & Repro. 5 & Repro. 6 & Repro. 7 & Repro. 8 & Repro. 9 & Repro. 10 \\
\hline $\mathrm{Pa} 231$ & 0 & 1.2E-01 & $1.2 \mathrm{E}-01$ & $1.2 \mathrm{E}-01$ & 1.2E-01 & 1.2E-01 & 1.2E-01 & $1.2 \mathrm{E}-01$ & $1.2 \mathrm{E}-01$ & $1.2 \mathrm{E}-01$ & $1.2 \mathrm{E}-01$ \\
\hline Np237 & $6.3 \mathrm{E}-01$ & $9.2 \mathrm{E}-01$ & $2.0 \mathrm{E}+00$ & $2.6 \mathrm{E}+00$ & $2.9 \mathrm{E}+00$ & $3.2 \mathrm{E}+00$ & $3.4 \mathrm{E}+00$ & $3.5 \mathrm{E}+00$ & $3.6 \mathrm{E}+00$ & $3.7 \mathrm{E}+00$ & $3.8 \mathrm{E}+00$ \\
\hline Pu238 & $2.9 \mathrm{E}-01$ & 1.3E-01 & 3.6E-01 & 5.0E-01 & $5.8 \mathrm{E}-01$ & $6.3 \mathrm{E}-01$ & 6.7E-01 & $6.9 \mathrm{E}-01$ & 7.1E-01 & 7.2E-01 & 7.3E-01 \\
\hline Pu239 & $6.2 \mathrm{E}+00$ & $1.6 \mathrm{E}+00$ & $1.6 \mathrm{E}+00$ & $1.6 \mathrm{E}+00$ & $1.6 \mathrm{E}+00$ & $1.6 \mathrm{E}+00$ & $1.6 \mathrm{E}+00$ & $1.6 \mathrm{E}+00$ & $1.6 \mathrm{E}+00$ & $1.5 \mathrm{E}+00$ & $1.5 \mathrm{E}+00$ \\
\hline Pu240 & $2.9 \mathrm{E}+00$ & $1.4 \mathrm{E}-01$ & $1.4 \mathrm{E}-01$ & 1.5E-01 & $1.5 \mathrm{E}-01$ & $1.5 \mathrm{E}-01$ & $1.5 \mathrm{E}-01$ & $1.5 \mathrm{E}-01$ & $1.5 \mathrm{E}-01$ & $1.5 \mathrm{E}-01$ & $1.5 \mathrm{E}-01$ \\
\hline Pu241 & $1.1 \mathrm{E}+00$ & $2.0 \mathrm{E}-02$ & 1.9E-02 & 1.9E-02 & 1.9E-02 & $1.9 \mathrm{E}-02$ & $1.9 \mathrm{E}-02$ & $1.9 \mathrm{E}-02$ & $1.8 \mathrm{E}-02$ & $1.8 \mathrm{E}-02$ & 1.7E-02 \\
\hline Pu242 & 8.6E-01 & $1.2 \mathrm{E}-03$ & $1.2 \mathrm{E}-03$ & 1.2E-03 & $1.2 \mathrm{E}-03$ & $1.2 \mathrm{E}-03$ & $1.2 \mathrm{E}-03$ & $1.2 \mathrm{E}-03$ & $1.1 \mathrm{E}-03$ & 1.1E-03 & 1.1E-03 \\
\hline Am241 & 7.3E-01 & $1.4 \mathrm{E}-02$ & $1.3 \mathrm{E}-02$ & 1.3E-02 & $1.3 \mathrm{E}-02$ & $1.3 \mathrm{E}-02$ & $1.3 \mathrm{E}-02$ & $1.3 \mathrm{E}-02$ & $1.2 \mathrm{E}-02$ & $1.2 \mathrm{E}-02$ & $1.2 \mathrm{E}-02$ \\
\hline Am242m & $8.2 \mathrm{E}-04$ & $1.5 \mathrm{E}-05$ & $1.4 \mathrm{E}-05$ & $1.3 \mathrm{E}-05$ & $1.3 \mathrm{E}-05$ & $1.3 \mathrm{E}-05$ & $1.3 \mathrm{E}-05$ & $1.3 \mathrm{E}-05$ & $1.2 \mathrm{E}-05$ & 1.2E-05 & $1.2 \mathrm{E}-05$ \\
\hline Am243 & 2.0E-01 & 9.7E-05 & 8.9E-05 & 9.1E-05 & 9.0E-05 & 8.9E-05 & 8.6E-05 & $8.2 \mathrm{E}-05$ & 7.9E-05 & 7.6E-05 & 7.3E-05 \\
\hline $\mathrm{Cm} 242$ & $2.0 \mathrm{E}-06$ & $3.9 \mathrm{E}-08$ & $3.5 \mathrm{E}-08$ & $3.5 \mathrm{E}-08$ & $3.5 \mathrm{E}-08$ & $3.5 \mathrm{E}-08$ & $3.4 \mathrm{E}-08$ & $3.3 \mathrm{E}-08$ & $3.2 \mathrm{E}-08$ & 3.1E-08 & $3.0 \mathrm{E}-08$ \\
\hline $\mathrm{Cm} 243$ & $6.0 \mathrm{E}-04$ & $1.2 \mathrm{E}-06$ & $1.1 \mathrm{E}-06$ & $1.2 \mathrm{E}-06$ & $1.2 \mathrm{E}-06$ & $1.2 \mathrm{E}-06$ & $1.1 \mathrm{E}-06$ & $1.1 \mathrm{E}-06$ & $1.0 \mathrm{E}-06$ & $1.0 \mathrm{E}-06$ & $9.8 \mathrm{E}-07$ \\
\hline $\mathrm{Cm} 244$ & $5.9 \mathrm{E}-02$ & $6.1 \mathrm{E}$ & 06 & 5.3 & 5.3 & $E-06$ & 06 & 4.7E-06 & $.4 \mathrm{E}-06$ & 4.2E-06 & 4.1E-06 \\
\hline $\mathrm{Cm} 245$ & 5.7E-03 & $5.0 \mathrm{E}-07$ & 4.4E-07 & $4.5 \mathrm{E}-07$ & $4.5 \mathrm{E}-07$ & $4.4 \mathrm{E}-07$ & $4.2 \mathrm{E}-07$ & 4.0E-07 & 3.7E-07 & $3.5 \mathrm{E}-07$ & $3.4 \mathrm{E}-07$ \\
\hline $\mathrm{Cm} 246$ & 7.3E-04 & $6.9 \mathrm{E}-09$ & 5.9E-09 & 6.1E-09 & $6.2 \mathrm{E}-09$ & 6.0E-09 & 5.7E-09 & 5.4E-09 & 5.1E-09 & 4.8E-09 & 4.5E-09 \\
\hline $\mathrm{Cm} 247$ & $1.0 \mathrm{E}-05$ & $1.0 \mathrm{E}-10$ & $8.9 \mathrm{E}-11$ & $9.2 \mathrm{E}-11$ & 9.4E-11 & $9.2 \mathrm{E}-11$ & 8.7E-11 & 8.1E-11 & 7.6E-11 & 7.1E-11 & $6.6 \mathrm{E}-11$ \\
\hline $\mathrm{Cm} 248$ & 7.7E-07 & $2.1 \mathrm{E}-12$ & $1.8 \mathrm{E}-12$ & $1.8 \mathrm{E}-12$ & $1.9 \mathrm{E}-12$ & $1.8 \mathrm{E}-12$ & 1.7E-12 & $1.6 \mathrm{E}-12$ & $1.5 \mathrm{E}-12$ & 1.4E-12 & $1.3 \mathrm{E}-12$ \\
\hline $\mathrm{Pa}$ & $0.0 \mathrm{E}+00$ & $1.2 \mathrm{E}-01$ & $1.2 \mathrm{E}-01$ & $1.2 \mathrm{E}-01$ & $1.2 \mathrm{E}-01$ & $1.2 \mathrm{E}-01$ & $1.2 \mathrm{E}-01$ & $1.2 \mathrm{E}-01$ & $1.2 \mathrm{E}-01$ & $1.2 \mathrm{E}-01$ & $1.2 \mathrm{E}-01$ \\
\hline $\mathrm{Np}$ & $6.3 \mathrm{E}-01$ & $9.2 \mathrm{E}-01$ & $2.0 \mathrm{E}+00$ & $2.6 \mathrm{E}+00$ & $2.9 \mathrm{E}+00$ & $3.2 \mathrm{E}+00$ & $3.4 \mathrm{E}+00$ & $3.5 \mathrm{E}+00$ & $3.6 \mathrm{E}+00$ & $3.7 E+00$ & $3.8 \mathrm{E}+00$ \\
\hline $\mathrm{Pu}$ & $1.1 \mathrm{E}+01$ & $1.8 \mathrm{E}+00$ & $2.1 \mathrm{E}+00$ & $2.2 \mathrm{E}+00$ & $2.3 E+00$ & $2.4 \mathrm{E}+00$ & $2.4 \mathrm{E}+00$ & $2.4 \mathrm{E}+00$ & $2.4 \mathrm{E}+00$ & $2.4 \mathrm{E}+00$ & $2.4 \mathrm{E}+00$ \\
\hline Am & $9.3 \mathrm{E}-01$ & $1.4 \mathrm{E}-02$ & $1.3 \mathrm{E}-02$ & $1.3 \mathrm{E}-02$ & $1.3 \mathrm{E}-02$ & $1.3 \mathrm{E}-02$ & $1.3 \mathrm{E}-02$ & $1.3 \mathrm{E}-02$ & $1.2 \mathrm{E}-02$ & $1.2 \mathrm{E}-02$ & $1.2 \mathrm{E}-02$ \\
\hline $\mathrm{Cm}$ & $6.6 \mathrm{E}-02$ & 7.9E-06 & $6.9 \mathrm{E}-06$ & 6.9E-06 & 6.9E-06 & $6.8 \mathrm{E}-06$ & $6.5 \mathrm{E}-06$ & $6.2 \mathrm{E}-06$ & 5.9E-06 & 5.6E-06 & 5.4E-06 \\
\hline Total & $1.3 E+01$ & $2.9 E+00$ & $4.2 E+00$ & $4.9 E+00$ & $5.4 \mathrm{E}+00$ & $5.7 E+00$ & $5.9 \mathrm{E}+00$ & $6.0 \mathrm{E}+00$ & $6.2 E+00$ & $6.3 E+00$ & $6.3 E+00$ \\
\hline
\end{tabular}


Improving Natural Uranium Utilization by Using Thorium in Low Moderation PWRs

Table C.5. Heavy-water-to-fuel volume ratio $=1-45,000 \mathrm{MWd} / \mathrm{t}-\mathrm{Th}-\mathrm{U}$ fuel -10 years after discharge

\begin{tabular}{|c|c|c|c|c|c|c|c|c|c|c|c|}
\hline $\mathrm{kg} / \mathrm{tlHM}$ & UO2 & Repro. 1 & Repro. 2 & Repro. 3 & Repro. 4 & Repro. 5 & Repro. 6 & Repro. 7 & Repro. 8 & Repro. 9 & Repro. 10 \\
\hline Pa231 & 0 & 1.7E-01 & 1.7E-01 & 1.7E-01 & 7E-01 & 1.7E-01 & 1.7E-01 & 1.7E-01 & 1.7E-01 & 1.7E-01 & 1.7E-01 \\
\hline Np237 & $6.3 \mathrm{E}-01$ & $6.6 \mathrm{E}-01$ & $1.5 \mathrm{E}+00$ & $2.0 \mathrm{E}+00$ & $2.3 \mathrm{E}+00$ & $2.5 \mathrm{E}+00$ & $2.5 \mathrm{E}+00$ & $2.6 \mathrm{E}+00$ & $2.6 \mathrm{E}+00$ & $2.6 \mathrm{E}+00$ & $2.5 \mathrm{E}+00$ \\
\hline Pu238 & $2.9 \mathrm{E}-01$ & 7.3E-02 & 2.3E-01 & 3.3E-01 & $3.9 \mathrm{E}-01$ & 4.3E-01 & 4.4E-01 & 4.5E-01 & 4.5E-01 & 4.5E-01 & 4.4E-01 \\
\hline Pu239 & $6.2 \mathrm{E}+00$ & $1.2 \mathrm{E}+00$ & $1.2 \mathrm{E}+00$ & $1.1 \mathrm{E}+00$ & $1.1 \mathrm{E}+00$ & $1.1 \mathrm{E}+00$ & $1.1 \mathrm{E}+00$ & $1.0 \mathrm{E}+00$ & $1.0 \mathrm{E}+00$ & $9.9 \mathrm{E}-01$ & $9.6 \mathrm{E}-01$ \\
\hline Pu240 & $2.9 E+00$ & 8.7E-02 & $9.2 \mathrm{E}-02$ & $9.5 \mathrm{E}-02$ & 9.6E-02 & $9.5 \mathrm{E}-02$ & $9.4 \mathrm{E}-02$ & $9.1 \mathrm{E}-02$ & 8.9E-02 & 8.6E-02 & 8.4E-02 \\
\hline Pu241 & $1.1 \mathrm{E}+00$ & 3.7E-03 & 3.91 & 03 & $E-03$ & $4.3 \mathrm{E}-03$ & $E-03$ & E-03 & $4.0 \mathrm{E}-03$ & $=-03$ & $E-03$ \\
\hline Pu242 & 8.6E-01 & 1.7 & 1. & $2.0 \mathrm{E}-04$ & 2.1E-04 & $2.2 \mathrm{E}-04$ & $E-04$ & $E-04$ & 04 & $=-04$ & -04 \\
\hline Am241 & 7.3E-01 & 2.7E-03 & $2.8 \mathrm{E}-03$ & $2.9 \mathrm{E}-03$ & 3.0E-03 & $3.0 \mathrm{E}-03$ & $3.0 \mathrm{E}-03$ & $3.0 \mathrm{E}-03$ & 2.9E-03 & $2.8 \mathrm{E}-03$ & 2.7E-03 \\
\hline Am242m & $8.2 \mathrm{E}-04$ & $2.9 \mathrm{E}-06$ & $3.0 \mathrm{E}-06$ & $3.2 \mathrm{E}-06$ & $3.4 \mathrm{E}-06$ & $3.4 \mathrm{E}-06$ & $3.4 \mathrm{E}-06$ & -06 & $3.2 \mathrm{E}-06$ & $3.1 \mathrm{E}-06$ & -06 \\
\hline Am243 & 2.0E-01 & 5.7E-06 & $6.1 \mathrm{E}-06$ & $6.8 \mathrm{E}-06$ & $7.2 \mathrm{E}-06$ & $7.5 \mathrm{E}-06$ & $7.5 \mathrm{E}-06$ & 7.3E-06 & 7.1E-06 & $6.9 \mathrm{E}-06$ & 7E-06 \\
\hline $\mathrm{Cm} 242$ & $2.0 \mathrm{E}-06$ & 7.5E-09 & 7.8E-09 & 8.4E-09 & 8.7E-09 & 8.9E-09 & 8.9E-09 & 8.7E-09 & 8.4E-09 & 8.2E-09 & 7.9E-09 \\
\hline $\mathrm{Cm} 243$ & $6.0 \mathrm{E}-04$ & $1.5 \mathrm{E}-07$ & $1.6 \mathrm{E}-07$ & $1.8 \mathrm{E}-07$ & $1.9 \mathrm{E}-07$ & $2.0 \mathrm{E}-07$ & $2.0 \mathrm{E}-07$ & $2.0 \mathrm{E}-07$ & $1.9 \mathrm{E}-07$ & $1.9 \mathrm{E}-07$ & $1.8 \mathrm{E}-07$ \\
\hline Cm244 & $5.9 \mathrm{E}-02$ & 2.3E-07 & $2.5 \mathrm{E}-07$ & 2.9E-07 & 3.1E-07 & $3.2 \mathrm{E}-07$ & 3.3E-07 & $3.2 \mathrm{E}-07$ & 3.1E-07 & 3.0E-07 & 2.9E-07 \\
\hline $\mathrm{Cm} 245$ & 5.7E-03 & 1.1E-08 & $1.2 \mathrm{E}-08$ & $1.4 \mathrm{E}-08$ & $1.6 \mathrm{E}-08$ & 1.7E-08 & 1.7E-08 & 1.7E-08 & $1.6 \mathrm{E}-08$ & -08 & $1.5 \mathrm{E}-08$ \\
\hline Cm246 & 7.3E-04 & $1.3 \mathrm{E}-10$ & $1.5 \mathrm{E}-10$ & $1.8 \mathrm{E}-10$ & 2.1E-10 & $2.2 \mathrm{E}-10$ & $2.3 \mathrm{E}-10$ & $2.3 \mathrm{E}-10$ & $2.2 \mathrm{E}-10$ & 2.1E-10 & 2.1E-10 \\
\hline $\mathrm{Cm} 247$ & $1.0 \mathrm{E}-05$ & $1.5 \mathrm{E}-12$ & $1.8 \mathrm{E}-12$ & $2.4 \mathrm{E}-12$ & $2.8 \mathrm{E}-12$ & $3.0 \mathrm{E}-12$ & $3.1 \mathrm{E}-12$ & $3.1 \mathrm{E}-12$ & $3.0 \mathrm{E}-12$ & $2.9 \mathrm{E}-12$ & $2.8 \mathrm{E}-12$ \\
\hline $\mathrm{Cm} 248$ & 7.7E-07 & 0 & 0 & 0 & 0 & 0 & 0 & 0 & 0 & 0 & 0 \\
\hline $\mathrm{Pa}$ & $0.0 \mathrm{E}+00$ & 1.7E-01 & 1.7E-01 & 1.7E-01 & 1.7E-01 & 1.7E-01 & 1.7E-01 & 1.7E-01 & 1.7E-01 & 1.7E-01 & 1.7E-01 \\
\hline $\mathrm{Np}$ & $6.3 \mathrm{E}-01$ & $6.6 \mathrm{E}-01$ & $1.5 \mathrm{E}+00$ & $2.0 \mathrm{E}+00$ & $2.3 E+00$ & $2.5 E+00$ & $2.5 E+00$ & $2.6 \mathrm{E}+00$ & $2.6 \mathrm{E}+00$ & $2.6 \mathrm{E}+00$ & $2.5 E+00$ \\
\hline $\mathrm{Pu}$ & $1.1 \mathrm{E}+01$ & $1.3 \mathrm{E}+00$ & $1.5 \mathrm{E}+00$ & $1.6 \mathrm{E}+00$ & $1.6 \mathrm{E}+00$ & $1.6 \mathrm{E}+00$ & $1.6 \mathrm{E}+00$ & $1.6 \mathrm{E}+00$ & $1.6 \mathrm{E}+00$ & $1.5 \mathrm{E}+00$ & $1.5 \mathrm{E}+00$ \\
\hline $\mathrm{Am}$ & $9.3 \mathrm{E}-01$ & 2.7E-03 & $2.8 \mathrm{E}-03$ & $2.9 \mathrm{E}-03$ & $3.0 \mathrm{E}-03$ & 3.1E-03 & $3.0 \mathrm{E}-03$ & $3.0 \mathrm{E}-03$ & 2.9E-03 & $2.8 \mathrm{E}-03$ & 2.7E-03 \\
\hline $\mathrm{Cm}$ & $6.6 \mathrm{E}-02$ & 4.0E-07 & 4.3E-07 & 4.9E-07 & 5.3E-07 & 5.5E-07 & 5.5E-07 & 5.4E-07 & 5.3E-07 & 5.1E-07 & 4.9E-07 \\
\hline Total & $1.3 \mathrm{E}+01$ & $2.2 \mathrm{E}+00$ & $3.2 \mathrm{E}+00$ & $3.8 \mathrm{E}+00$ & $4.1 \mathrm{E}+00$ & $4.3 E+00$ & $4.3 \mathrm{E}+00$ & $4.3 \mathrm{E}+00$ & $4.3 \mathrm{E}+00$ & $4.3 E+00$ & $4.2 E+00$ \\
\hline
\end{tabular}

Table C.6. Heavy-water-to-fuel volume ratio $=0.6-45,000 \mathrm{MWd} / \mathrm{t}-\mathrm{Th}-\mathrm{U}$ fuel -10 years after discharge

\begin{tabular}{|c|c|c|c|c|c|c|c|c|c|c|c|}
\hline $\mathrm{kg} / \mathrm{tlHM}$ & UO2 & Repro. 1 & Repro. 2 & Repro. 3 & Repro. 4 & Repro. 5 & Repro. 6 & Repro. 7 & Repro. 8 & Repro. 9 & Repro. 10 \\
\hline Pa231 & 0 & $9 \mathrm{E}-01$ & E-01 & 2.0E-01 & 2.0E-01 & E-01 & $2.0 \mathrm{E}$ & $2.0 \mathrm{E}-01$ & $2.0 \mathrm{E}-01$ & 2.0E-01 & OE-01 \\
\hline Np237 & $6.3 \mathrm{E}-01$ & $6.0 \mathrm{E}-01$ & $1.3 \mathrm{E}+00$ & $1.8 \mathrm{E}+00$ & $2.0 \mathrm{E}+00$ & $2.1 \mathrm{E}+00$ & $2.1 \mathrm{E}+00$ & $2.1 \mathrm{E}+00$ & $2.0 \mathrm{E}+00$ & $1.9 \mathrm{E}+00$ & $1.9 \mathrm{E}+00$ \\
\hline Pu238 & $2.9 \mathrm{E}-01$ & $6.5 \mathrm{E}-02$ & 1.9E-01 & 2.7E-01 & 3.1E-01 & $3.4 \mathrm{E}-01$ & $3.4 \mathrm{E}-01$ & $3.4 \mathrm{E}-01$ & 3.3E-01 & $3.2 \mathrm{E}-01$ & 3.1E-01 \\
\hline Pu239 & $6.2 E+00$ & $1.0 \mathrm{E}+00$ & $9.8 \mathrm{E}-01$ & 9.4E-01 & 9.1E-01 & 8.7E-01 & 8.3E-01 & 7.9E-01 & 7.4E-01 & 7.0E-01 & $6.6 \mathrm{E}-01$ \\
\hline Pu240 & $2.9 \mathrm{E}+00$ & 7.5E-02 & 7.2E-02 & 7.0E-02 & 6.9E-02 & $6.8 \mathrm{E}-02$ & $6.5 \mathrm{E}-02$ & $6.2 \mathrm{E}-02$ & 5.9E-02 & $5.6 \mathrm{E}-02$ & 5.3E-02 \\
\hline Pu241 & $1.1 \mathrm{E}+00$ & $3.1 \mathrm{E}-03$ & $2.5 \mathrm{E}-03$ & $2.3 \mathrm{E}-03$ & $2.3 \mathrm{E}-03$ & $2.3 \mathrm{E}-03$ & $2.3 \mathrm{E}-03$ & $2.2 \mathrm{E}-03$ & 2.1E-03 & 2.0E-03 & $1.9 \mathrm{E}-03$ \\
\hline Pu242 & 8.6E-01 & $1.4 \mathrm{E}-04$ & $1.1 \mathrm{E}-04$ & 1.0E-04 & 1.1E-04 & 1.1E-04 & 1.1E-04 & $1.0 \mathrm{E}-04$ & $1.0 \mathrm{E}-04$ & $9.5 \mathrm{E}-05$ & $9.0 \mathrm{E}-05$ \\
\hline Am241 & 7.3E-01 & $2.3 \mathrm{E}-03$ & $1.8 \mathrm{E}-03$ & 1.7E-03 & 1.7E-03 & 1.7E-03 & 1.7E-03 & $1.6 \mathrm{E}-03$ & $1.5 \mathrm{E}-03$ & $1.5 \mathrm{E}-03$ & $1.4 \mathrm{E}-03$ \\
\hline Am242m & $8.2 \mathrm{E}-04$ & $2.9 \mathrm{E}-06$ & $2.2 \mathrm{E}-06$ & $2.0 \mathrm{E}-06$ & 2.1E-06 & $2.2 \mathrm{E}-06$ & 2.1E-06 & $2.1 \mathrm{E}-06$ & $2.0 \mathrm{E}-06$ & 1.9E-06 & $1.8 \mathrm{E}-06$ \\
\hline Am243 & $2.0 \mathrm{E}-01$ & 4.7E-06 & $3.2 \mathrm{E}-06$ & $2.8 \mathrm{E}-06$ & $3.0 \mathrm{E}-06$ & 3.1E-06 & 3.1E-06 & $3.0 \mathrm{E}-06$ & $2.9 \mathrm{E}-06$ & $2.8 \mathrm{E}-06$ & $2.6 \mathrm{E}-06$ \\
\hline $\mathrm{Cm} 242$ & $2.0 \mathrm{E}-06$ & 7.5E-09 & 5.7E-09 & 5.3E-09 & 5.6E-09 & 5.6E-09 & 5.6E-09 & $5.4 \mathrm{E}-09$ & 5.1E-09 & 4.9E-09 & 4.6E-09 \\
\hline $\mathrm{Cm} 243$ & $6.0 \mathrm{E}-04$ & $1.2 \mathrm{E}-07$ & $9.3 \mathrm{E}-08$ & 8.7E-08 & $9.5 \mathrm{E}-08$ & $9.8 \mathrm{E}-08$ & $9.8 \mathrm{E}-08$ & $9.5 \mathrm{E}-08$ & $9.2 \mathrm{E}-08$ & 8.7E-08 & $8.2 \mathrm{E}-08$ \\
\hline $\mathrm{Cm} 244$ & $5.9 \mathrm{E}-02$ & $1.9 \mathrm{E}-07$ & $1.2 \mathrm{E}-07$ & 1.1E-07 & $1.2 \mathrm{E}-07$ & 1.3E-07 & $1.3 \mathrm{E}-07$ & $1.2 \mathrm{E}-07$ & $1.2 \mathrm{E}-07$ & 1.1E-07 & $1.1 \mathrm{E}-07$ \\
\hline $\mathrm{Cm} 245$ & 5.7E-03 & 8.1E-09 & 4.9E-09 & 4.3E-09 & 5.0E-09 & 5.3E-09 & 5.5E-09 & $5.4 \mathrm{E}-09$ & 5.2E-09 & 5.0E-09 & 4.8E-09 \\
\hline $\mathrm{Cm} 246$ & 7.3E-04 & $1.0 \mathrm{E}-10$ & $6.3 \mathrm{E}-11$ & $5.6 \mathrm{E}-11$ & $6.6 \mathrm{E}-11$ & 7.2E-11 & 7.4E-11 & $7.4 \mathrm{E}-11$ & $7.2 \mathrm{E}-11$ & $6.9 \mathrm{E}-11$ & $6.5 \mathrm{E}-11$ \\
\hline $\mathrm{Cm} 247$ & $1.0 \mathrm{E}-05$ & $1.1 \mathrm{E}-12$ & $5.9 \mathrm{E}-13$ & 4.9E-13 & $6.5 \mathrm{E}-13$ & 7.7E-13 & 8.0E-13 & 8.0E-13 & $7.8 \mathrm{E}-13$ & 7.0E-13 & $6.6 \mathrm{E}-13$ \\
\hline $\mathrm{Cm} 248$ & 7.7E-07 & 0 & 0 & 0 & 0 & 0 & 0 & 0 & 0 & 0 & 0 \\
\hline $\mathrm{Pa}$ & $0.0 \mathrm{E}+00$ & 1.9E-01 & 1.9E-01 & 2.0E-01 & 2.0E-01 & 2.0E-01 & 2.0E-01 & 2.0E-01 & 2.0E-01 & 2.0E-01 & 2.0E-01 \\
\hline $\mathrm{Np}$ & $6.3 \mathrm{E}-01$ & $6.0 \mathrm{E}-01$ & $1.3 \mathrm{E}+00$ & $1.8 \mathrm{E}+00$ & $2.0 \mathrm{E}+00$ & $2.1 \mathrm{E}+00$ & $2.1 \mathrm{E}+00$ & $2.1 \mathrm{E}+00$ & $2.0 \mathrm{E}+00$ & $1.9 \mathrm{E}+00$ & $1.9 \mathrm{E}+00$ \\
\hline $\mathrm{Pu}$ & $1.1 \mathrm{E}+01$ & $1.2 \mathrm{E}+00$ & $1.2 \mathrm{E}+00$ & $1.3 \mathrm{E}+00$ & $1.3 \mathrm{E}+00$ & $1.3 \mathrm{E}+00$ & $1.2 \mathrm{E}+00$ & $1.2 \mathrm{E}+00$ & $1.1 \mathrm{E}+00$ & $1.1 \mathrm{E}+00$ & $1.0 \mathrm{E}+00$ \\
\hline Am & $9.3 \mathrm{E}-01$ & 2.3E-03 & $1.8 \mathrm{E}-03$ & 1.7E-03 & 1.7E-03 & 1.7E-03 & 1.7E-03 & $1.6 \mathrm{E}-03$ & $1.5 \mathrm{E}-03$ & $1.5 \mathrm{E}-03$ & $1.4 \mathrm{E}-03$ \\
\hline $\mathrm{Cm}$ & $6.6 \mathrm{E}-02$ & 3.2E-07 & 2.2E-07 & 2.1E-07 & 2.3E-07 & 2.3E-07 & $2.4 \mathrm{E}-07$ & 2.3E-07 & $2.2 \mathrm{E}-07$ & 2.1E-07 & 2.0E-07 \\
\hline Total & $1.3 E+01$ & $2.0 \mathrm{E}+00$ & $2.8 \mathrm{E}+00$ & $3.2 E+00$ & $3.5 \mathrm{E}+00$ & $3.6 \mathrm{E}+00$ & $3.5 E+00$ & $3.4 \mathrm{E}+00$ & $3.3 E+00$ & $3.2 \mathrm{E}+00$ & $3.1 E+00$ \\
\hline
\end{tabular}


Improving Natural Uranium Utilization by Using Thorium in Low Moderation PWRs October 2010

Table C.7. Heavy-water-to-fuel volume ratio $=1-60,000 \mathrm{MWd} / \mathrm{t}-\mathrm{Th}-\mathrm{U}$ fuel -10 years after discharge

\begin{tabular}{|c|c|c|c|c|c|c|c|c|c|c|c|}
\hline $\mathrm{kg} / \mathrm{tlHM}$ & UO2 & Repro. 1 & Repro. 2 & Repro. 3 & Repro. 4 & Repro. 5 & Repro. 6 & Repro. 7 & Repro. 8 & Repro. 9 & Repro. 10 \\
\hline Pa231 & 0 & 2.1E-01 & 2.1E-01 & 2.1E-01 & 2.1E-01 & 2.1E-01 & 2.1E-01 & 2.1E-01 & 2.1E-01 & $2.1 \mathrm{E}-01$ & 2.1E-01 \\
\hline Np237 & $6.3 \mathrm{E}-01$ & $1.1 \mathrm{E}+00$ & $2.3 \mathrm{E}+00$ & $2.9 \mathrm{E}+00$ & $3.2 E+00$ & $3.3 E+00$ & $3.3 E+00$ & $3.3 \mathrm{E}+00$ & $3.3 \mathrm{E}+00$ & $3.3 E+00$ & $3.2 E+00$ \\
\hline Pu238 & $2.9 \mathrm{E}-01$ & 1.6E-01 & $4.5 \mathrm{E}-01$ & $6.2 \mathrm{E}-01$ & 7.0E-01 & 7.3E-01 & 7.4E-01 & 7.4E-01 & 7.4E-01 & 7.3E-01 & 7.3E-01 \\
\hline Pu239 & $6.2 \mathrm{E}+00$ & $1.5 \mathrm{E}+00$ & $1.4 \mathrm{E}+00$ & $1.4 \mathrm{E}+00$ & $1.4 \mathrm{E}+00$ & $1.4 \mathrm{E}+00$ & $1.3 \mathrm{E}+00$ & $1.3 \mathrm{E}+00$ & $1.3 \mathrm{E}+00$ & $1.2 \mathrm{E}+00$ & $1.2 \mathrm{E}+00$ \\
\hline Pu240 & $2.9 \mathrm{E}+00$ & $1.5 \mathrm{E}-01$ & $1.5 \mathrm{E}-01$ & 1.6E-01 & 1.6E-01 & $1.5 \mathrm{E}-01$ & $1.5 \mathrm{E}-01$ & $1.5 \mathrm{E}-01$ & $1.4 \mathrm{E}-01$ & 1.4E-01 & $1.3 \mathrm{E}-01$ \\
\hline Pu241 & $1.1 \mathrm{E}+00$ & $8.9 \mathrm{E}-03$ & 7.9E-03 & 8.3E-03 & 8.4E-03 & 8.3E-03 & 8.1E-03 & 7.9E-03 & 7.7E-03 & 7.4E-03 & 7.2E-03 \\
\hline Pu242 & 8.6E-01 & $5.8 \mathrm{E}-04$ & $5.0 \mathrm{E}-04$ & $5.4 \mathrm{E}-04$ & 5.6E-04 & $5.6 \mathrm{E}-04$ & $5.4 \mathrm{E}-04$ & $5.3 \mathrm{E}-04$ & 5.1E-04 & 5.0E-04 & $4.8 \mathrm{E}-04$ \\
\hline Am241 & 7.3E-01 & 6.7E-03 & $5.8 \mathrm{E}-03$ & 6.1E-03 & $6.2 \mathrm{E}-03$ & $6.2 \mathrm{E}-03$ & $6.0 \mathrm{E}-03$ & $5.8 \mathrm{E}-03$ & 5.7E-03 & $5.5 \mathrm{E}-03$ & $5.3 \mathrm{E}-03$ \\
\hline Am $242 m$ & $8.2 \mathrm{E}-04$ & $1.2 \mathrm{E}-05$ & 1.0E-05 & 05 & 05 & -05 & 1.1E-05 & $1.1 \mathrm{E}-05$ & $1.0 \mathrm{E}-05$ & -05 & $9.8 \mathrm{E}-06$ \\
\hline Am243 & 2.0E-01 & 2.8 & 2.2 & 2.4 & 2.5 & -05 & $2.4 \mathrm{E}-05$ & -05 & -05 & -05 & E-05 \\
\hline $\mathrm{Cm} 242$ & $2.0 \mathrm{E}-06$ & 3.2 & 08 & 08 & 3.0E-08 & E-08 & $2.9 \mathrm{E}-08$ & $2.8 \mathrm{E}-08$ & 2.7E-08 & $2.6 \mathrm{E}-08$ & $\mathrm{E}-08$ \\
\hline $\mathrm{Cm} 243$ & $6.0 \mathrm{E}-04$ & 7.3E-07 & $6.3 \mathrm{E}-07$ & 7.0E-07 & 7.3E-07 & 7.3E-07 & $7.2 \mathrm{E}-07$ & $6.9 \mathrm{E}-07$ & $6.8 \mathrm{E}-07$ & $6.5 \mathrm{E}-07$ & $6.3 \mathrm{E}-07$ \\
\hline $\mathrm{Cm} 244$ & $5.9 \mathrm{E}-02$ & 1.6E-06 & 1.2 & 1.3 & $1.4 \mathrm{E}-06$ & $1.4 \mathrm{E}-06$ & $1.4 \mathrm{E}-06$ & $1.3 \mathrm{E}-06$ & $1.3 \mathrm{E}-06$ & -06 & E-06 \\
\hline $\mathrm{Cm} 245$ & 5.7E-03 & $1.0 \mathrm{E}-07$ & 7.1E-08 & $8.4 \mathrm{E}-08$ & 9.1E-08 & $9.2 \mathrm{E}-08$ & $9.0 \mathrm{E}-08$ & 8.7E-08 & 08 & 08 & -08 \\
\hline $\mathrm{Cm} 246$ & 7.3E-04 & 1.7E-09 & $1.2 \mathrm{E}-09$ & $1.5 \mathrm{E}-09$ & 1.6E-09 & 1.6E-09 & 1.6E-09 & 1.6E-09 & 1.5E-09 & $1.4 \mathrm{E}-09$ & $1.4 \mathrm{E}-09$ \\
\hline $\mathrm{Cm} 247$ & $1.0 \mathrm{E}-05$ & $3.1 \mathrm{E}-11$ & $2.2 \mathrm{E}-11$ & 2.7E-11 & 3.0E-11 & 3.1E-11 & $3.0 \mathrm{E}-11$ & $2.9 \mathrm{E}-11$ & $2.8 \mathrm{E}-11$ & 2.7E-11 & $E-11$ \\
\hline $\mathrm{Cm} 248$ & 7.7E-07 & $5.6 \mathrm{E}-13$ & $3.8 \mathrm{E}-13$ & $4.9 \mathrm{E}-13$ & $5.6 \mathrm{E}-13$ & $5.8 \mathrm{E}-13$ & 5.7E-13 & $5.4 \mathrm{E}-13$ & $0.0 \mathrm{E}+00$ & $0.0 \mathrm{E}+00$ & 4.7E-13 \\
\hline $\mathrm{Pa}$ & $0.0 \mathrm{E}+00$ & 2.1E-01 & 2.1E-01 & 2.1E-01 & 2.1E-01 & 2.1E-01 & 2.1E-01 & 2.1E-01 & 2.1E-01 & 2.1E-01 & 2.1E-01 \\
\hline $\mathrm{Np}$ & $6.3 \mathrm{E}-01$ & $1.1 \mathrm{E}+00$ & $2.3 \mathrm{E}+00$ & $2.9 \mathrm{E}+00$ & $3.2 \mathrm{E}+00$ & $3.3 E+00$ & $3.3 E+00$ & $3.3 \mathrm{E}+00$ & $3.3 \mathrm{E}+00$ & $3.3 \mathrm{E}+00$ & $3.2 \mathrm{E}+00$ \\
\hline $\mathrm{Pu}$ & $1.1 \mathrm{E}+01$ & $1.8 \mathrm{E}+00$ & $2.1 \mathrm{E}+00$ & $2.2 \mathrm{E}+00$ & $2.3 E+00$ & $2.3 E+00$ & $2.2 \mathrm{E}+00$ & $2.2 \mathrm{E}+00$ & $2.2 \mathrm{E}+00$ & $2.1 \mathrm{E}+00$ & $2.1 \mathrm{E}+00$ \\
\hline $\mathrm{Am}$ & $9.3 \mathrm{E}-01$ & 6.7E-03 & $5.9 \mathrm{E}-03$ & $6.2 \mathrm{E}-03$ & $6.3 \mathrm{E}-03$ & $6.2 \mathrm{E}-03$ & $6.0 \mathrm{E}-03$ & $5.8 \mathrm{E}-03$ & 5.7E-03 & 5.5E-03 & $5.4 \mathrm{E}-03$ \\
\hline $\mathrm{Cm}$ & $6.6 \mathrm{E}-02$ & 2.4E-06 & $1.9 \mathrm{E}-06$ & 2.1E-06 & 2.3E-06 & 2.3E-06 & 2.2E-06 & 2.1E-06 & 2.1E-06 & 2.0E-06 & 1.9E-06 \\
\hline Total & $1.3 \mathrm{E}+01$ & $3.1 E+00$ & $4.5 E+00$ & $5.3 E+00$ & $5.6 \mathrm{E}+00$ & $5.8 \mathrm{E}+00$ & $5.8 \mathrm{E}+00$ & $5.7 E+00$ & $5.7 \mathrm{E}+00$ & $5.6 \mathrm{E}+00$ & $5.5 \mathrm{E}+00$ \\
\hline
\end{tabular}

Table C.8. Heavy-water-to-fuel volume ratio $=0.6-60,000 \mathrm{MWd} / \mathrm{t}-\mathrm{Th}-\mathrm{U}$ fuel -10 years after discharge

\begin{tabular}{|c|c|c|c|c|c|c|c|c|c|c|c|}
\hline $\mathrm{kg} / \mathrm{tlHM}$ & UO2 & Repro. 1 & Repro. 2 & Repro. 3 & Repro. 4 & Repro. 5 & Repro. 6 & Repro. 7 & Repro. 8 & Repro. 9 & Repro. 10 \\
\hline $\mathrm{Pa} 231$ & 0 & $2.4 \mathrm{E}-01$ & 2.4E-01 & $2.5 \mathrm{E}-01$ & $2.5 \mathrm{E}-01$ & $2.5 \mathrm{E}-01$ & $2.5 \mathrm{E}-01$ & $2.5 \mathrm{E}-01$ & 2.5E-01 & $2.5 \mathrm{E}-01$ & $2.5 \mathrm{E}-01$ \\
\hline Np237 & $6.3 \mathrm{E}-01$ & 9.7E-01 & $2.0 \mathrm{E}+00$ & $2.5 \mathrm{E}+00$ & $2.7 \mathrm{E}+00$ & $2.7 \mathrm{E}+00$ & $2.7 E+00$ & $2.6 \mathrm{E}+00$ & $2.5 \mathrm{E}+00$ & $2.4 \mathrm{E}+00$ & $2.3 E+00$ \\
\hline Pu238 & $2.9 \mathrm{E}-01$ & 1.4E-01 & $3.9 \mathrm{E}-01$ & 5.2E-01 & $5.8 \mathrm{E}-01$ & $6.0 \mathrm{E}-01$ & 5.9E-01 & 5.7E-01 & 5.5E-01 & $5.4 \mathrm{E}-01$ & $5.2 \mathrm{E}-01$ \\
\hline Pu239 & $6.2 \mathrm{E}+00$ & $1.3 \mathrm{E}+00$ & $1.2 \mathrm{E}+00$ & $1.2 \mathrm{E}+00$ & $1.2 \mathrm{E}+00$ & $1.1 \mathrm{E}+00$ & $1.0 \mathrm{E}+00$ & $9.8 \mathrm{E}-01$ & $9.2 \mathrm{E}-01$ & 8.7E-01 & $8.2 \mathrm{E}-01$ \\
\hline Pu240 & $2.9 \mathrm{E}+00$ & 1.3E-01 & $1.2 \mathrm{E}-01$ & 1.2E-01 & $1.2 \mathrm{E}-01$ & $1.2 \mathrm{E}-01$ & 1.1E-01 & 1.1E-01 & $9.9 \mathrm{E}-02$ & $9.3 \mathrm{E}-02$ & $8.8 \mathrm{E}-02$ \\
\hline Pu241 & $1.1 \mathrm{E}+00$ & $6.8 \mathrm{E}-03$ & $5.8 \mathrm{E}-03$ & 6.0E-03 & 6.1E-03 & $5.9 \mathrm{E}-03$ & $5.6 \mathrm{E}-03$ & $5.3 \mathrm{E}-03$ & $5.0 \mathrm{E}-03$ & $4.8 \mathrm{E}-03$ & 4.5E-03 \\
\hline Pu242 & 8.6E-01 & 4.3E-04 & $3.6 \mathrm{E}-04$ & 3.9E-04 & 4.0E-04 & $3.9 E-04$ & $3.8 \mathrm{E}-04$ & $3.6 \mathrm{E}-04$ & $3.4 \mathrm{E}-04$ & $3.2 \mathrm{E}-04$ & 3.0E-04 \\
\hline Am241 & 7.3E-01 & $5.3 \mathrm{E}-03$ & 4.4E-03 & 4.6E-03 & 4.7E-03 & $4.5 \mathrm{E}-03$ & 4.3E-03 & 4.1E-03 & $3.9 \mathrm{E}-03$ & 3.7E-03 & $3.4 \mathrm{E}-03$ \\
\hline Am242m & $8.2 \mathrm{E}-04$ & 1.1E-05 & $9.1 \mathrm{E}-06$ & 9.7E-06 & 9.9E-06 & 9.7E-06 & $9.3 \mathrm{E}-06$ & $8.9 \mathrm{E}-06$ & $8.4 \mathrm{E}-06$ & 7.9E-06 & 7.5E-06 \\
\hline Am243 & 2.0E-01 & 2.0E-05 & $1.5 \mathrm{E}-05$ & 1.6E-05 & 1.7E-05 & 1.7E-05 & $1.6 \mathrm{E}-05$ & $1.6 \mathrm{E}-05$ & $1.5 \mathrm{E}-05$ & $1.4 \mathrm{E}-05$ & 1.3E-05 \\
\hline $\mathrm{Cm} 242$ & $2.0 \mathrm{E}-06$ & $2.9 \mathrm{E}-08$ & $2.4 \mathrm{E}-08$ & $2.5 \mathrm{E}-08$ & $2.6 \mathrm{E}-08$ & $2.5 \mathrm{E}-08$ & $2.4 \mathrm{E}-08$ & $2.3 \mathrm{E}-08$ & $2.2 \mathrm{E}-08$ & 2.1E-08 & $2.0 \mathrm{E}-08$ \\
\hline $\mathrm{Cm} 243$ & $6.0 \mathrm{E}-04$ & $5.4 \mathrm{E}-07$ & $4.4 \mathrm{E}-07$ & 5.0E-07 & $5.2 \mathrm{E}-07$ & 5.1E-07 & $4.9 \mathrm{E}-07$ & 4.7E-07 & 4.5E-07 & $4.2 \mathrm{E}-07$ & 4.0E-07 \\
\hline $\mathrm{Cm} 244$ & $5.9 \mathrm{E}-02$ & $1.1 \mathrm{E}$ & 7.6E-07 & $8.8 \mathrm{E}-07$ & -07 & $9.3 \mathrm{E}-07$ & $9.0 \mathrm{E}-07$ & 8.6E-07 & $8.1 \mathrm{E}-07$ & 7.6E-07 & $7.2 \mathrm{E}-07$ \\
\hline $\mathrm{Cm} 245$ & 5.7E-03 & $6.4 \mathrm{E}-08$ & 4.3E-08 & 5.1E-08 & 5.6E-08 & $5.6 \mathrm{E}-08$ & $5.5 \mathrm{E}-08$ & $5.3 \mathrm{E}-08$ & 5.0E-08 & 4.7E-08 & 4.5E-08 \\
\hline $\mathrm{Cm} 246$ & 7.3E-04 & 1.1E-09 & 7.4E-10 & $9.1 \mathrm{E}-10$ & 1.0E-09 & 1.0E-09 & 1.0E-09 & $9.6 \mathrm{E}-10$ & $9.2 \mathrm{E}-10$ & 8.7E-10 & $8.2 \mathrm{E}-10$ \\
\hline $\mathrm{Cm} 247$ & $1.0 \mathrm{E}-05$ & $1.9 \mathrm{E}-11$ & $1.3 \mathrm{E}-11$ & $1.6 \mathrm{E}-11$ & $1.8 \mathrm{E}-11$ & $1.9 \mathrm{E}-11$ & $1.8 \mathrm{E}-11$ & $1.8 \mathrm{E}-11$ & $1.7 \mathrm{E}-11$ & $1.6 \mathrm{E}-11$ & $1.5 \mathrm{E}-11$ \\
\hline $\mathrm{Cm} 248$ & 7.7E-07 & $3.3 \mathrm{E}-13$ & $2.2 \mathrm{E}-13$ & $2.8 \mathrm{E}-13$ & $3.3 \mathrm{E}-13$ & $3.4 \mathrm{E}-13$ & $3.3 \mathrm{E}-13$ & $3.2 \mathrm{E}-13$ & 3.0E-13 & $2.9 \mathrm{E}-13$ & 2.7E-13 \\
\hline $\mathrm{Pa}$ & $0.0 \mathrm{E}+00$ & 2.4E-01 & 2.4E-01 & 2.5E-01 & 2.5E-01 & $2.5 \mathrm{E}-01$ & $2.5 \mathrm{E}-01$ & 2.5E-01 & 2.5E-01 & $2.5 \mathrm{E}-01$ & 2.5E-01 \\
\hline $\mathrm{Np}$ & $6.3 \mathrm{E}-01$ & 9.7E-01 & $2.0 \mathrm{E}+00$ & $2.5 \mathrm{E}+00$ & $2.7 E+00$ & $2.7 E+00$ & $2.7 E+00$ & $2.6 \mathrm{E}+00$ & $2.5 E+00$ & $2.4 \mathrm{E}+00$ & $2.3 E+00$ \\
\hline $\mathrm{Pu}$ & $1.1 \mathrm{E}+01$ & $1.6 \mathrm{E}+00$ & $1.8 \mathrm{E}+00$ & $1.9 \mathrm{E}+00$ & $1.9 \mathrm{E}+00$ & $1.8 \mathrm{E}+00$ & 1.7E+00 & 1.7E+00 & $1.6 \mathrm{E}+00$ & $1.5 \mathrm{E}+00$ & $1.4 \mathrm{E}+00$ \\
\hline Am & $9.3 \mathrm{E}-01$ & 5.3E-03 & 4.4E-03 & 4.7E-03 & 4.7E-03 & 4.5E-03 & 4.4E-03 & 4.1E-03 & $3.9 \mathrm{E}-03$ & 3.7E-03 & 3.5E-03 \\
\hline $\mathrm{Cm}$ & $6.6 \mathrm{E}-02$ & 1.7E-06 & $1.3 \mathrm{E}-06$ & 1.5E-06 & 1.5E-06 & $1.5 \mathrm{E}-06$ & $1.5 \mathrm{E}-06$ & $1.4 \mathrm{E}-06$ & $1.3 \mathrm{E}-06$ & $1.3 \mathrm{E}-06$ & $1.2 \mathrm{E}-06$ \\
\hline Total & $1.3 E+01$ & $2.8 \mathrm{E}+00$ & $4.0 \mathrm{E}+00$ & $4.6 \mathrm{E}+00$ & $4.8 \mathrm{E}+00$ & $4.8 \mathrm{E}+00$ & 4.7E+00 & $4.5 E+00$ & $4.3 E+00$ & $4.2 \mathrm{E}+00$ & $4.0 \mathrm{E}+00$ \\
\hline
\end{tabular}


Improving Natural Uranium Utilization by Using Thorium in Low Moderation PWRs

Table C.9. Heavy-water-to-fuel volume ratio $=1-45,000 \mathrm{MWd} / \mathrm{t}-\mathrm{Th}-\mathrm{U}-\mathrm{Pu}$ fuel -5 years after discharge

\begin{tabular}{|c|c|c|c|c|c|c|c|c|c|c|c|}
\hline $\mathrm{kg} / \mathrm{tlHM}$ & UO2 & Repro. 1 & Repro. 2 & Repro. 3 & Repro. 4 & Repro. 5 & Repro. 6 & Repro. 7 & Repro. 8 & Repro. 9 & Repro. 10 \\
\hline $\mathrm{Pa} 231$ & 0 & 1.7E-01 & 1.7E-01 & 1.7E-01 & 1.7E-01 & 1.7E-01 & 1.7E-01 & 1.7E-01 & 1.7E-01 & 1.7E-01 & 1.7E-01 \\
\hline Np237 & 6.3E-01 & 5.6E-01 & $1.0 \mathrm{E}+00$ & $1.3 \mathrm{E}+00$ & $1.5 \mathrm{E}+00$ & $1.7 \mathrm{E}+00$ & $1.7 \mathrm{E}+00$ & $1.8 \mathrm{E}+00$ & $1.8 \mathrm{E}+00$ & $1.8 \mathrm{E}+00$ & $1.8 \mathrm{E}+00$ \\
\hline Pu238 & 2.9E-01 & 0 & 0 & 0 & 0 & 0 & 0 & 0 & 0 & 0 & 0 \\
\hline Pu239 & $6.2 E+00$ & 0 & 0 & 0 & 0 & 0 & 0 & 0 & 0 & 0 & 0 \\
\hline Pu240 & $2.9 \mathrm{E}+00$ & 0 & 0 & 0 & 0 & 0 & 0 & 0 & 0 & 0 & 0 \\
\hline Pu241 & $1.1 \mathrm{E}+00$ & 0 & 0 & 0 & 0 & 0 & 0 & 0 & 0 & 0 & 0 \\
\hline Pu242 & 8.6E-01 & 0 & 0 & 0 & 0 & 0 & 0 & 0 & 0 & 0 & 0 \\
\hline Am241 & 7.3E-01 & $3.5 \mathrm{E}+00$ & $2.4 \mathrm{E}+00$ & $1.9 \mathrm{E}+00$ & $1.6 \mathrm{E}+00$ & $1.4 \mathrm{E}+00$ & $1.2 \mathrm{E}+00$ & $1.1 \mathrm{E}+00$ & $9.6 \mathrm{E}-01$ & $8.4 \mathrm{E}-01$ & 7.3E-01 \\
\hline Am $242 m$ & $8.2 \mathrm{E}-04$ & 4.9E-02 & $3.0 \mathrm{E}-02$ & $2.1 \mathrm{E}-02$ & 1.7E-02 & 1.5E-02 & $1.3 \mathrm{E}-02$ & $1.2 \mathrm{E}-02$ & $1.0 \mathrm{E}-02$ & $8.8 \mathrm{E}-03$ & 7.7E-03 \\
\hline Am243 & 2.0E-01 & $1.2 \mathrm{E}+00$ & $8.2 \mathrm{E}-01$ & 7.1E-01 & $6.3 \mathrm{E}-01$ & $5.8 \mathrm{E}-01$ & $5.2 \mathrm{E}-01$ & 4.9E-01 & 4.3E-01 & 4.0E-01 & 3.7E-01 \\
\hline $\mathrm{Cm} 242$ & $2.0 \mathrm{E}-06$ & 1.7E-04 & $9.8 \mathrm{E}-05$ & 7.0E-05 & 5.7E-05 & 4.9E-05 & 4.3E-05 & $3.9 \mathrm{E}-05$ & $3.4 \mathrm{E}-05$ & $2.9 \mathrm{E}-05$ & $2.6 \mathrm{E}-05$ \\
\hline $\mathrm{Cm} 243$ & $6.0 \mathrm{E}-04$ & 4.9E-03 & 2.7E-03 & $1.9 \mathrm{E}-03$ & $1.5 \mathrm{E}-03$ & $1.3 \mathrm{E}-03$ & 1.1E-03 & $1.0 \mathrm{E}-03$ & $8.6 \mathrm{E}-04$ & 7.6E-04 & 6.7E-04 \\
\hline $\mathrm{Cm} 244$ & $5.9 \mathrm{E}-02$ & 2.9E-01 & 1.3E-01 & 1.1E-01 & $9.5 \mathrm{E}-02$ & 8.5E-02 & 7.6E-02 & 7.1E-02 & $6.2 \mathrm{E}-02$ & $5.8 \mathrm{E}-02$ & $5.4 \mathrm{E}-02$ \\
\hline $\mathrm{Cm} 245$ & 5.7E-03 & 4.9E-02 & $1.6 \mathrm{E}-02$ & $1.2 \mathrm{E}-02$ & 9.7E-03 & 8.6E-03 & 7.3E-03 & 7.0E-03 & 5.7E-03 & $5.4 \mathrm{E}-03$ & $5.1 \mathrm{E}-03$ \\
\hline $\mathrm{Cm} 246$ & 7.3E-04 & $1.4 \mathrm{E}-03$ & 4.2E-04 & $3.3 \mathrm{E}-04$ & 2.7E-04 & $2.3 \mathrm{E}-04$ & $2.0 \mathrm{E}-04$ & 1.9E-04 & 1.6E-04 & $1.5 \mathrm{E}-04$ & $1.4 \mathrm{E}-04$ \\
\hline $\mathrm{Cm} 247$ & $1.0 \mathrm{E}-05$ & $3.8 \mathrm{E}-05$ & 1.1E-05 & 8.3E-06 & 6.7E-06 & $6.0 \mathrm{E}-06$ & 5.1E-06 & 4.9E-06 & 4.0E-06 & $3.8 \mathrm{E}-06$ & $3.6 \mathrm{E}-06$ \\
\hline $\mathrm{Cm} 248$ & 7.7E-07 & 1.4E-06 & 3.0E-07 & $2.2 \mathrm{E}-07$ & 1.7E-07 & $1.5 \mathrm{E}-07$ & $1.3 \mathrm{E}-07$ & $1.2 \mathrm{E}-07$ & 9.7E-08 & 9.3E-08 & $8.8 \mathrm{E}-08$ \\
\hline $\mathrm{Pa}$ & $0.0 \mathrm{E}+00$ & 1.7E-01 & 1.7E-01 & 1.7E-01 & 1.7E-01 & 1.7E-01 & $1.7 \mathrm{E}-01$ & 1.7E-01 & 1.7E-01 & 1.7E-01 & 1.7E-01 \\
\hline $\mathrm{Np}$ & $6.3 \mathrm{E}-01$ & 5.6E-01 & $1.0 \mathrm{E}+00$ & $1.3 E+00$ & $1.5 \mathrm{E}+00$ & 1.7E+00 & $1.7 \mathrm{E}+00$ & $1.8 \mathrm{E}+00$ & $1.8 \mathrm{E}+00$ & $1.8 \mathrm{E}+00$ & $1.8 \mathrm{E}+00$ \\
\hline $\mathrm{Pu}$ & $1.1 \mathrm{E}+01$ & $0.0 \mathrm{E}+00$ & $0.0 \mathrm{E}+00$ & $0.0 E+00$ & $0.0 \mathrm{E}+00$ & $0.0 \mathrm{E}+00$ & $0.0 \mathrm{E}+00$ & $0.0 E+00$ & $0.0 \mathrm{E}+00$ & $0.0 \mathrm{E}+00$ & $0.0 \mathrm{E}+00$ \\
\hline Am & 9.3E-01 & $4.8 \mathrm{E}+00$ & $3.3 E+00$ & $2.6 \mathrm{E}+00$ & $2.2 \mathrm{E}+00$ & $2.0 \mathrm{E}+00$ & $1.8 \mathrm{E}+00$ & $1.6 \mathrm{E}+00$ & $1.4 \mathrm{E}+00$ & $1.2 \mathrm{E}+00$ & $1.1 \mathrm{E}+00$ \\
\hline $\mathrm{Cm}$ & $6.6 \mathrm{E}-02$ & 3.4E-01 & $1.5 \mathrm{E}-01$ & $1.2 \mathrm{E}-01$ & 1.1E-01 & 9.5E-02 & 8.4E-02 & 8.0E-02 & $6.9 \mathrm{E}-02$ & $6.5 \mathrm{E}-02$ & $6.0 \mathrm{E}-02$ \\
\hline Total & $1.3 \mathrm{E}+01$ & $5.9 E+00$ & $4.6 \mathrm{E}+00$ & $4.2 E+00$ & $4.0 \mathrm{E}+00$ & $3.9 \mathrm{E}+00$ & $3.7 E+00$ & $3.6 \mathrm{E}+00$ & $3.4 \mathrm{E}+00$ & $3.3 E+00$ & $3.1 E+00$ \\
\hline
\end{tabular}

Table C.10. Heavy-water-to-fuel volume ratio $=0.6-45,000 \mathrm{MWd} / \mathrm{t}-\mathrm{Th}-\mathrm{U}-\mathrm{Pu}$ fuel $\mathbf{- 5}$ years after discharge

\begin{tabular}{|c|c|c|c|c|c|c|c|c|c|c|c|}
\hline $\mathrm{kg} / \mathrm{tlHM}$ & UO2 & Repro. 1 & Repro. 2 & Repro. 3 & Repro. 4 & Repro. 5 & Repro. 6 & Repro. 7 & Repro. 8 & Repro. 9 & Repro. 10 \\
\hline Pa231 & 0 & $2.0 \mathrm{E}-01$ & $2.0 \mathrm{E}-01$ & 2.0E-01 & $2.0 \mathrm{E}-01$ & $2.0 \mathrm{E}-01$ & $2.0 \mathrm{E}-01$ & $2.0 \mathrm{E}-01$ & $2.0 \mathrm{E}-01$ & $2.0 \mathrm{E}-01$ & $2.0 \mathrm{E}-01$ \\
\hline Np237 & $6.3 \mathrm{E}-01$ & $4.8 \mathrm{E}-01$ & 8.6E-01 & $1.1 \mathrm{E}+00$ & $1.2 \mathrm{E}+00$ & $1.3 \mathrm{E}+00$ & $1.3 \mathrm{E}+00$ & $1.2 \mathrm{E}+00$ & $1.2 \mathrm{E}+00$ & $1.2 \mathrm{E}+00$ & $1.1 \mathrm{E}+00$ \\
\hline Pu238 & $2.9 \mathrm{E}-01$ & 0 & 0 & 0 & 0 & 0 & 0 & 0 & 0 & 0 & 0 \\
\hline Pu239 & $6.2 E+00$ & 0 & 0 & 0 & 0 & 0 & 0 & 0 & 0 & 0 & 0 \\
\hline Pu240 & $2.9 \mathrm{E}+00$ & 0 & 0 & 0 & 0 & 0 & 0 & 0 & 0 & 0 & 0 \\
\hline Pu241 & $1.1 \mathrm{E}+00$ & 0 & 0 & 0 & 0 & 0 & 0 & 0 & 0 & 0 & 0 \\
\hline Pu242 & 8.6E-01 & 0 & 0 & 0 & 0 & 0 & 0 & 0 & 0 & 0 & 0 \\
\hline Am241 & 7.3E-01 & $3.5 E+00$ & $2.3 \mathrm{E}+00$ & $1.8 \mathrm{E}+00$ & $1.6 \mathrm{E}+00$ & $1.4 \mathrm{E}+00$ & $1.2 \mathrm{E}+00$ & $1.0 \mathrm{E}+00$ & 9.1E-01 & $7.8 \mathrm{E}-01$ & $6.7 \mathrm{E}-01$ \\
\hline Am242m & $8.2 \mathrm{E}-04$ & $5.3 \mathrm{E}-02$ & 3.0E-02 & 2.1E-02 & $1.8 \mathrm{E}-02$ & $1.5 \mathrm{E}-02$ & $1.3 \mathrm{E}-02$ & $1.2 \mathrm{E}-02$ & 1.0E-02 & $8.8 \mathrm{E}-03$ & 7.6E-03 \\
\hline Am243 & $2.0 \mathrm{E}-01$ & $1.1 \mathrm{E}+00$ & 7.7E-01 & 6.7E-01 & 6.1E-01 & 5.4E-01 & 4.9E-01 & 4.5E-01 & 4.1E-01 & 3.7E-01 & 3.4E-01 \\
\hline $\mathrm{Cm} 242$ & $2.0 \mathrm{E}-06$ & 1.7E-04 & $9.6 \mathrm{E}-05$ & $6.9 \mathrm{E}-05$ & 5.7E-05 & 4.9E-05 & 4.3E-05 & $3.8 \mathrm{E}-05$ & 3.3E-05 & 2.8E-05 & 2.4E-05 \\
\hline $\mathrm{Cm} 243$ & $6.0 \mathrm{E}-04$ & 4.3E-03 & $2.2 \mathrm{E}-03$ & $1.5 \mathrm{E}-03$ & $1.3 \mathrm{E}-03$ & 1.1E-03 & $9.4 \mathrm{E}-04$ & 8.1E-04 & 7.2E-04 & $6.1 \mathrm{E}-04$ & $5.3 \mathrm{E}-04$ \\
\hline $\mathrm{Cm} 244$ & $5.9 \mathrm{E}-02$ & $2.2 \mathrm{E}-01$ & $1.2 \mathrm{E}-01$ & 1.0E-01 & $9.0 \mathrm{E}-02$ & 7.9E-02 & 7.1E-02 & $6.4 \mathrm{E}-02$ & 5.9E-02 & $5.2 \mathrm{E}-02$ & $4.8 \mathrm{E}-02$ \\
\hline $\mathrm{Cm} 245$ & 5.7E-03 & $3.4 \mathrm{E}-02$ & $1.3 \mathrm{E}-02$ & 1.0E-02 & 8.9E-03 & $7.5 \mathrm{E}-03$ & 6.7E-03 & $5.8 \mathrm{E}-03$ & $5.5 \mathrm{E}-03$ & 4.7E-03 & 4.3E-03 \\
\hline $\mathrm{Cm} 246$ & 7.3E-04 & $1.0 \mathrm{E}-03$ & $3.6 \mathrm{E}-04$ & 2.9E-04 & $2.5 \mathrm{E}-04$ & 2.1E-04 & $1.9 \mathrm{E}-04$ & 1.7E-04 & $1.6 \mathrm{E}-04$ & $1.3 \mathrm{E}-04$ & $1.2 \mathrm{E}-04$ \\
\hline $\mathrm{Cm} 247$ & $1.0 \mathrm{E}-05$ & 2.7E-05 & 9.1E-06 & 7.3E-06 & 6.4E-06 & 5.4E-06 & $4.8 \mathrm{E}-06$ & $4.2 \mathrm{E}-06$ & 4.0E-06 & 3.3E-06 & $3.1 \mathrm{E}-06$ \\
\hline $\mathrm{Cm} 248$ & 7.7E-07 & $9.5 \mathrm{E}-07$ & $2.5 \mathrm{E}-07$ & 1.9E-07 & 1.6E-07 & 1.4E-07 & $1.2 \mathrm{E}-07$ & $1.0 \mathrm{E}-07$ & $9.9 \mathrm{E}-08$ & 8.1E-08 & 7.7E-08 \\
\hline $\mathrm{Pa}$ & $0.0 \mathrm{E}+00$ & 2.0E-01 & $2.0 \mathrm{E}-01$ & 2.0E-01 & 2.0E-01 & 2.0E-01 & 2.0E-01 & 2.0E-01 & 2.0E-01 & 2.0E-01 & 2.0E-01 \\
\hline $\mathrm{Np}$ & $6.3 \mathrm{E}-01$ & $4.8 \mathrm{E}-01$ & 8.6E-01 & $1.1 \mathrm{E}+00$ & $1.2 E+00$ & $1.3 E+00$ & $1.3 E+00$ & $1.2 \mathrm{E}+00$ & $1.2 \mathrm{E}+00$ & $1.2 \mathrm{E}+00$ & $1.1 E+00$ \\
\hline $\mathrm{Pu}$ & $1.1 \mathrm{E}+01$ & $0.0 E+00$ & $0.0 E+00$ & $0.0 \mathrm{E}+00$ & $0.0 \mathrm{E}+00$ & $0.0 E+00$ & $0.0 E+00$ & $0.0 \mathrm{E}+00$ & $0.0 E+00$ & $0.0 \mathrm{E}+00$ & $0.0 \mathrm{E}+00$ \\
\hline Am & 9.3E-01 & 4.7E+00 & $3.1 E+00$ & $2.5 \mathrm{E}+00$ & $2.2 E+00$ & $1.9 \mathrm{E}+00$ & $1.7 \mathrm{E}+00$ & $1.5 \mathrm{E}+00$ & $1.3 E+00$ & $1.2 \mathrm{E}+00$ & $1.0 \mathrm{E}+00$ \\
\hline $\mathrm{Cm}$ & $6.6 \mathrm{E}-02$ & 2.6E-01 & $1.3 \mathrm{E}-01$ & 1.1E-01 & 1.0E-01 & $8.8 \mathrm{E}-02$ & 7.9E-02 & 7.1E-02 & $6.6 \mathrm{E}-02$ & $5.8 \mathrm{E}-02$ & 5.3E-02 \\
\hline Total & $1.3 E+01$ & $5.6 E+00$ & $4.3 E+00$ & $3.9 E+00$ & 3.7E+00 & $3.5 E+00$ & $3.2 E+00$ & $3.0 \mathrm{E}+00$ & $2.8 \mathrm{E}+00$ & $2.6 \mathrm{E}+00$ & $2.4 \mathrm{E}+00$ \\
\hline
\end{tabular}


Improving Natural Uranium Utilization by Using Thorium in Low Moderation PWRs

Table C.11. Heavy-water-to-fuel volume ratio $=1-45,000 \mathrm{MWd} / \mathrm{t}-\mathrm{U}-\mathrm{Pu}$ fuel -5 years after discharge

\begin{tabular}{|c|c|c|c|c|c|c|c|c|c|c|c|}
\hline kg/tIHM & UO2 & Repro. 1 & Repro. 2 & Repro. 3 & Repro. 4 & Repro. 5 & Repro. 6 & Repro. 7 & Repro. 8 & Repro. 9 & Repro. 10 \\
\hline Pa231 & 0 & 0 & 0 & 0 & 0 & 0 & 0 & 0 & 0 & 0 & 0 \\
\hline Np237 & $6.3 \mathrm{E}-01$ & $5.6 \mathrm{E}-01$ & $1.0 \mathrm{E}+00$ & $1.4 \mathrm{E}+00$ & $1.6 \mathrm{E}+00$ & $1.8 \mathrm{E}+00$ & $1.9 \mathrm{E}+00$ & $2.0 \mathrm{E}+00$ & $2.0 \mathrm{E}+00$ & $2.1 \mathrm{E}+00$ & $2.1 \mathrm{E}+00$ \\
\hline Pu238 & 2.9E-01 & 0 & 0 & 0 & 0 & 0 & 0 & 0 & 0 & 0 & 0 \\
\hline Pu239 & $6.2 \mathrm{E}+00$ & 0 & 0 & 0 & 0 & 0 & 0 & 0 & 0 & 0 & 0 \\
\hline Pu240 & $2.9 \mathrm{E}+00$ & 0 & 0 & 0 & 0 & 0 & 0 & 0 & 0 & 0 & 0 \\
\hline Pu241 & $1.1 \mathrm{E}+00$ & 0 & 0 & 0 & 0 & 0 & 0 & 0 & 0 & 0 & 0 \\
\hline Pu242 & 8.6E-01 & 0 & 0 & 0 & 0 & 0 & 0 & 0 & 0 & 0 & 0 \\
\hline Am241 & 7.3E-01 & $3.2 \mathrm{E}+00$ & $2.3 \mathrm{E}+00$ & $2.3 \mathrm{E}+00$ & $2.4 \mathrm{E}+00$ & $2.6 \mathrm{E}+00$ & $2.8 \mathrm{E}+00$ & $3.0 \mathrm{E}+00$ & $3.1 \mathrm{E}+00$ & $3.2 \mathrm{E}+00$ & $3.3 E+00$ \\
\hline Am $242 m$ & $8.2 \mathrm{E}-04$ & 4.7E-02 & $2.9 \mathrm{E}-02$ & $2.6 \mathrm{E}-02$ & $2.6 \mathrm{E}-02$ & $2.8 \mathrm{E}-02$ & $3.1 \mathrm{E}-02$ & $3.3 \mathrm{E}-02$ & $3.4 \mathrm{E}-02$ & $3.6 \mathrm{E}-02$ & 3.7E-02 \\
\hline Am243 & 2.0E-01 & $8.2 \mathrm{E}-01$ & $7.8 \mathrm{E}-01$ & 7.3E-01 & $6.9 \mathrm{E}-01$ & 6.7E-01 & $6.5 \mathrm{E}-01$ & $6.3 \mathrm{E}-01$ & $6.3 \mathrm{E}-01$ & $6.2 \mathrm{E}-01$ & $6.2 \mathrm{E}-01$ \\
\hline $\mathrm{Cm} 242$ & $2.0 \mathrm{E}-06$ & $1.5 \mathrm{E}-04$ & $9.6 \mathrm{E}-05$ & $8.5 \mathrm{E}-05$ & $8.8 \mathrm{E}-05$ & $9.5 \mathrm{E}-05$ & $1.0 \mathrm{E}-04$ & $1.1 \mathrm{E}-04$ & $1.1 \mathrm{E}-04$ & $1.2 \mathrm{E}-04$ & $1.2 \mathrm{E}-04$ \\
\hline $\mathrm{Cm} 243$ & $6.0 \mathrm{E}-04$ & $4.3 \mathrm{E}-03$ & $2.6 \mathrm{E}-03$ & $2.3 \mathrm{E}-03$ & $2.4 \mathrm{E}-03$ & $2.5 \mathrm{E}-03$ & 2.7E-03 & $2.9 \mathrm{E}-03$ & $3.0 \mathrm{E}-03$ & $3.1 \mathrm{E}-03$ & $3.2 \mathrm{E}-03$ \\
\hline $\mathrm{Cm} 244$ & $5.9 E-02$ & $1.4 \mathrm{E}-01$ & $1.3 \mathrm{E}-01$ & $1.2 \mathrm{E}-01$ & $1.2 \mathrm{E}-01$ & 1.1E-01 & $1.1 \mathrm{E}-01$ & $1.0 \mathrm{E}-01$ & $1.0 \mathrm{E}-01$ & $1.0 \mathrm{E}-01$ & $1.0 \mathrm{E}-01$ \\
\hline $\mathrm{Cm} 245$ & 5.7E-03 & $1.3 \mathrm{E}-02$ & $1.2 \mathrm{E}-02$ & 1.1E-02 & $1.1 \mathrm{E}-02$ & $1.0 \mathrm{E}-02$ & 9.7E-03 & $9.4 \mathrm{E}-03$ & $9.3 \mathrm{E}-03$ & $9.2 \mathrm{E}-03$ & $9.1 \mathrm{E}-03$ \\
\hline $\mathrm{Cm} 246$ & 7.3E-04 & $4.0 \mathrm{E}-04$ & $3.9 E-04$ & $3.6 \mathrm{E}-04$ & $3.4 \mathrm{E}-04$ & $3.2 \mathrm{E}-04$ & $3.1 \mathrm{E}-04$ & $3.0 \mathrm{E}-04$ & $2.9 \mathrm{E}-04$ & $2.9 \mathrm{E}-04$ & $2.9 \mathrm{E}-04$ \\
\hline Cm247 & $1.0 \mathrm{E}-05$ & $1.2 \mathrm{E}-05$ & $1.1 \mathrm{E}-05$ & 1.0E-05 & $9.8 \mathrm{E}-06$ & $9.3 \mathrm{E}-06$ & $8.9 E-06$ & 8.6E-06 & $8.4 \mathrm{E}-06$ & $8.3 \mathrm{E}-06$ & $8.2 \mathrm{E}-06$ \\
\hline Cm248 & 7.7E-07 & $3.3 \mathrm{E}-07$ & $3.1 \mathrm{E}-07$ & $2.9 \mathrm{E}-07$ & $2.8 \mathrm{E}-07$ & 2.6E-07 & $2.5 \mathrm{E}-07$ & $2.4 \mathrm{E}-07$ & $2.3 \mathrm{E}-07$ & $2.3 \mathrm{E}-07$ & $2.3 \mathrm{E}-07$ \\
\hline $\mathrm{Pa}$ & $0.0 \mathrm{E}+00$ & $0.0 \mathrm{E}+00$ & $0.0 \mathrm{E}+00$ & $0.0 \mathrm{E}+00$ & $0.0 \mathrm{E}+00$ & $0.0 \mathrm{E}+00$ & $0.0 \mathrm{E}+00$ & $0.0 \mathrm{E}+00$ & $0.0 \mathrm{E}+00$ & $0.0 \mathrm{E}+00$ & $0.0 \mathrm{E}+00$ \\
\hline $\mathrm{Np}$ & $6.3 \mathrm{E}-01$ & $5.6 \mathrm{E}-01$ & $1.0 \mathrm{E}+00$ & $1.4 \mathrm{E}+00$ & $1.6 \mathrm{E}+00$ & $1.8 \mathrm{E}+00$ & $1.9 \mathrm{E}+00$ & $2.0 \mathrm{E}+00$ & $2.0 \mathrm{E}+00$ & $2.1 \mathrm{E}+00$ & $2.1 \mathrm{E}+00$ \\
\hline $\mathrm{Pu}$ & $1.1 \mathrm{E}+01$ & $0.0 \mathrm{E}+00$ & $0.0 \mathrm{E}+00$ & $0.0 \mathrm{E}+00$ & $0.0 \mathrm{E}+00$ & $0.0 \mathrm{E}+00$ & $0.0 \mathrm{E}+00$ & $0.0 \mathrm{E}+00$ & $0.0 \mathrm{E}+00$ & $0.0 \mathrm{E}+00$ & $0.0 \mathrm{E}+00$ \\
\hline $\mathrm{Am}$ & 9.3E-01 & $4.0 \mathrm{E}+00$ & $3.1 \mathrm{E}+00$ & $3.0 \mathrm{E}+00$ & $3.1 \mathrm{E}+00$ & $3.3 \mathrm{E}+00$ & $3.5 \mathrm{E}+00$ & $3.6 \mathrm{E}+00$ & $3.8 \mathrm{E}+00$ & $3.9 \mathrm{E}+00$ & 4.0E+00 \\
\hline $\mathrm{Cm}$ & $6.6 \mathrm{E}-02$ & $1.6 \mathrm{E}-01$ & 1.5E-01 & 1.4E-01 & $1.3 \mathrm{E}-01$ & $1.2 \mathrm{E}-01$ & $1.2 \mathrm{E}-01$ & $1.2 \mathrm{E}-01$ & $1.2 \mathrm{E}-01$ & 1.1E-01 & 1.1E-01 \\
\hline Total & $1.3 \mathrm{E}+01$ & $4.8 \mathrm{E}+00$ & $4.3 \mathrm{E}+00$ & $4.5 \mathrm{E}+00$ & $4.8 \mathrm{E}+00$ & $5.2 \mathrm{E}+00$ & $5.4 \mathrm{E}+00$ & $5.7 \mathrm{E}+00$ & $5.9 \mathrm{E}+00$ & $6.1 \mathrm{E}+00$ & $6.2 \mathrm{E}+00$ \\
\hline
\end{tabular}

Table C.12. Heavy-water-to-fuel volume ratio $=0.6-45,000 \mathrm{MWd} / \mathrm{t}-\mathrm{U}-\mathrm{Pu}$ fuel -5 years after discharge

\begin{tabular}{|c|c|c|c|c|c|c|c|c|c|c|c|}
\hline $\mathrm{kg} / \mathrm{tlHM}$ & UO2 & Repro. 1 & Repro. 2 & Repro. 3 & Repro. 4 & Repro. 5 & Repro. 6 & Repro. 7 & Repro. 8 & Repro. 9 & Repro. 10 \\
\hline $\mathrm{Pa} 231$ & 0 & 0 & 0 & 0 & 0 & 0 & 0 & 0 & 0 & 0 & 0 \\
\hline Np237 & $6.3 \mathrm{E}-01$ & 4.9E-01 & 8.1E-01 & 9.9E-01 & $1.1 \mathrm{E}+00$ & $1.1 \mathrm{E}+00$ & $1.1 \mathrm{E}+00$ & $1.0 \mathrm{E}+00$ & $9.5 \mathrm{E}-01$ & 8.7E-01 & 8.0E-01 \\
\hline Pu238 & $2.9 \mathrm{E}-01$ & 0 & 0 & 0 & 0 & 0 & 0 & 0 & 0 & 0 & 0 \\
\hline Pu239 & $6.2 \mathrm{E}+00$ & 0 & 0 & 0 & 0 & 0 & 0 & 0 & 0 & 0 & 0 \\
\hline Pu240 & $2.9 \mathrm{E}+00$ & 0 & 0 & 0 & 0 & 0 & 0 & 0 & 0 & 0 & 0 \\
\hline Pu241 & $1.1 \mathrm{E}+00$ & 0 & 0 & 0 & 0 & 0 & 0 & 0 & 0 & 0 & 0 \\
\hline Pu242 & 8.6E-01 & 0 & 0 & 0 & 0 & 0 & 0 & 0 & 0 & 0 & 0 \\
\hline Am241 & 7.3E-01 & $3.3 \mathrm{E}+00$ & $2.3 \mathrm{E}+00$ & $2.2 \mathrm{E}+00$ & $2.4 \mathrm{E}+00$ & $2.6 \mathrm{E}+00$ & $2.8 \mathrm{E}+00$ & $3.0 \mathrm{E}+00$ & $3.2 \mathrm{E}+00$ & $3.3 E+00$ & $3.4 \mathrm{E}+00$ \\
\hline Am242m & $8.2 \mathrm{E}-04$ & 5.1E-02 & 3.0E-02 & $2.6 \mathrm{E}-02$ & $2.8 \mathrm{E}-02$ & $3.1 \mathrm{E}-02$ & 3.3E-02 & $3.6 \mathrm{E}-02$ & $3.8 \mathrm{E}-02$ & 4.0E-02 & 4.1E-02 \\
\hline Am243 & $2.0 \mathrm{E}-01$ & 7.6E-01 & 7.3E-01 & $6.8 \mathrm{E}-01$ & $6.4 \mathrm{E}-01$ & $6.2 \mathrm{E}-01$ & 6.0E-01 & 5.9E-01 & $5.8 \mathrm{E}-01$ & $5.8 \mathrm{E}-01$ & 5.8E-01 \\
\hline $\mathrm{Cm} 242$ & $2.0 \mathrm{E}-06$ & $1.6 \mathrm{E}-04$ & $9.6 \mathrm{E}-05$ & 8.5E-05 & 9.0E-05 & 9.9E-05 & 1.1E-04 & $1.2 \mathrm{E}-04$ & $1.2 \mathrm{E}-04$ & $1.3 \mathrm{E}-04$ & $1.3 \mathrm{E}-04$ \\
\hline $\mathrm{Cm} 243$ & $6.0 \mathrm{E}-04$ & 3.7E-03 & $2.1 \mathrm{E}-03$ & 1.9E-03 & 2.0E-03 & $2.2 \mathrm{E}-03$ & $2.4 \mathrm{E}-03$ & $2.6 \mathrm{E}-03$ & 2.7E-03 & $2.8 \mathrm{E}-03$ & $2.9 \mathrm{E}-03$ \\
\hline $\mathrm{Cm} 244$ & $5.9 \mathrm{E}-02$ & $1.2 \mathrm{E}-01$ & $1.2 \mathrm{E}-01$ & 1.1E-01 & 1.1E-01 & $1.0 \mathrm{E}-01$ & $9.8 \mathrm{E}-02$ & $9.6 \mathrm{E}-02$ & $9.5 \mathrm{E}-02$ & $9.4 \mathrm{E}-02$ & $9.4 \mathrm{E}-02$ \\
\hline $\mathrm{Cm} 245$ & 5.7E-03 & $9.5 \mathrm{E}-03$ & $9.4 \mathrm{E}-03$ & $9.0 \mathrm{E}-03$ & 8.7E-03 & 8.3E-03 & 8.1E-03 & 8.0E-03 & 7.9E-03 & $7.8 \mathrm{E}-03$ & $7.8 \mathrm{E}-03$ \\
\hline $\mathrm{Cm} 246$ & 7.3E-04 & $3.2 \mathrm{E}-04$ & $3.2 \mathrm{E}-04$ & 3.1E-04 & 3.0E-04 & $2.9 \mathrm{E}-04$ & $2.8 \mathrm{E}-04$ & $2.8 \mathrm{E}-04$ & $2.8 \mathrm{E}-04$ & 2.7E-04 & 2.7E-04 \\
\hline $\mathrm{Cm} 247$ & $1.0 \mathrm{E}-05$ & $9.0 \mathrm{E}-06$ & $9.3 \mathrm{E}-06$ & 9.1E-06 & 8.8E-06 & 8.6E-06 & $8.5 \mathrm{E}-06$ & $8.4 \mathrm{E}-06$ & 8.3E-06 & 8.1E-06 & 8.0E-06 \\
\hline $\mathrm{Cm} 248$ & 7.7E-07 & $2.4 \mathrm{E}-07$ & $2.5 \mathrm{E}-07$ & 2.5E-07 & $2.5 \mathrm{E}-07$ & $2.4 \mathrm{E}-07$ & $2.4 \mathrm{E}-07$ & $2.4 \mathrm{E}-07$ & 2.3E-07 & 2.3E-07 & 2.3E-07 \\
\hline $\mathrm{Pa}$ & $0.0 \mathrm{E}+00$ & $0.0 \mathrm{E}+00$ & $0.0 \mathrm{E}+00$ & $0.0 \mathrm{E}+00$ & $0.0 \mathrm{E}+00$ & $0.0 \mathrm{E}+00$ & $0.0 \mathrm{E}+00$ & $0.0 \mathrm{E}+00$ & $0.0 \mathrm{E}+00$ & $0.0 \mathrm{E}+00$ & $0.0 \mathrm{E}+00$ \\
\hline $\mathrm{Np}$ & $6.3 \mathrm{E}-01$ & 4.9E-01 & 8.1E-01 & 9.9E-01 & $1.1 E+00$ & $1.1 \mathrm{E}+00$ & $1.1 \mathrm{E}+00$ & $1.0 \mathrm{E}+00$ & $9.5 \mathrm{E}-01$ & 8.7E-01 & 8.0E-01 \\
\hline $\mathrm{Pu}$ & $1.1 \mathrm{E}+01$ & $0.0 \mathrm{E}+00$ & $0.0 \mathrm{E}+00$ & $0.0 \mathrm{E}+00$ & $0.0 \mathrm{E}+00$ & $0.0 \mathrm{E}+00$ & $0.0 \mathrm{E}+00$ & $0.0 \mathrm{E}+00$ & $0.0 \mathrm{E}+00$ & $0.0 \mathrm{E}+00$ & $0.0 \mathrm{E}+00$ \\
\hline Am & $9.3 \mathrm{E}-01$ & $4.1 \mathrm{E}+00$ & $3.0 \mathrm{E}+00$ & $2.9 \mathrm{E}+00$ & $3.0 \mathrm{E}+00$ & $3.2 \mathrm{E}+00$ & $3.5 E+00$ & $3.6 \mathrm{E}+00$ & $3.8 \mathrm{E}+00$ & $3.9 \mathrm{E}+00$ & $4.1 \mathrm{E}+00$ \\
\hline $\mathrm{Cm}$ & $6.6 \mathrm{E}-02$ & $1.3 \mathrm{E}-01$ & $1.3 \mathrm{E}-01$ & $1.2 \mathrm{E}-01$ & $1.2 \mathrm{E}-01$ & 1.1E-01 & 1.1E-01 & 1.1E-01 & 1.1E-01 & 1.1E-01 & 1.1E-01 \\
\hline Total & $1.3 E+01$ & 4.7E+00 & $4.0 \mathrm{E}+00$ & $4.0 \mathrm{E}+00$ & $4.2 \mathrm{E}+00$ & $4.5 \mathrm{E}+00$ & $4.6 \mathrm{E}+00$ & $4.8 \mathrm{E}+00$ & $4.9 E+00$ & $4.9 \mathrm{E}+00$ & $5.0 \mathrm{E}+00$ \\
\hline
\end{tabular}




\section{Appendix D}

Heat load related to the TRU that needs to be disposed of $(\underline{\mathrm{W} / \mathrm{t} \mid \mathrm{HM}})$ for the different fuels, coolants and water-to-fuel volume ratios.

The heat load related to the TRU and Fission Products in a reference $\mathrm{UO}_{2}$ spent fuel irradiated up to $51,000 \mathrm{MWd} / \mathrm{t}$ is presented for comparison.

The heat load related to the TRU was calculated with ORIGEN-ARP, whereas that of the $\mathrm{UO}_{2}$ Fission Products was taken from the reference [D.1] below. As a first approximation, for a given burnup, the heat load related to the FP can be considered fuel-independent, i.e. the curves corresponding to the FP produced in the Thorium fuels should be similar to that of the $\mathrm{UO}_{2} \mathrm{FP}$.

[D.1] R. A.. Wigeland, "Criteria Derived for Geologic Disposal Concepts", OECD/NEA 9th Information Exchange Meeting on Actinide and Fission Product Partitioning and Transmutation, Sept. 2006, available online at http://www.nea.fr/html/pt/iempt9/Nimes Presentations/WIGELAND.pdf 


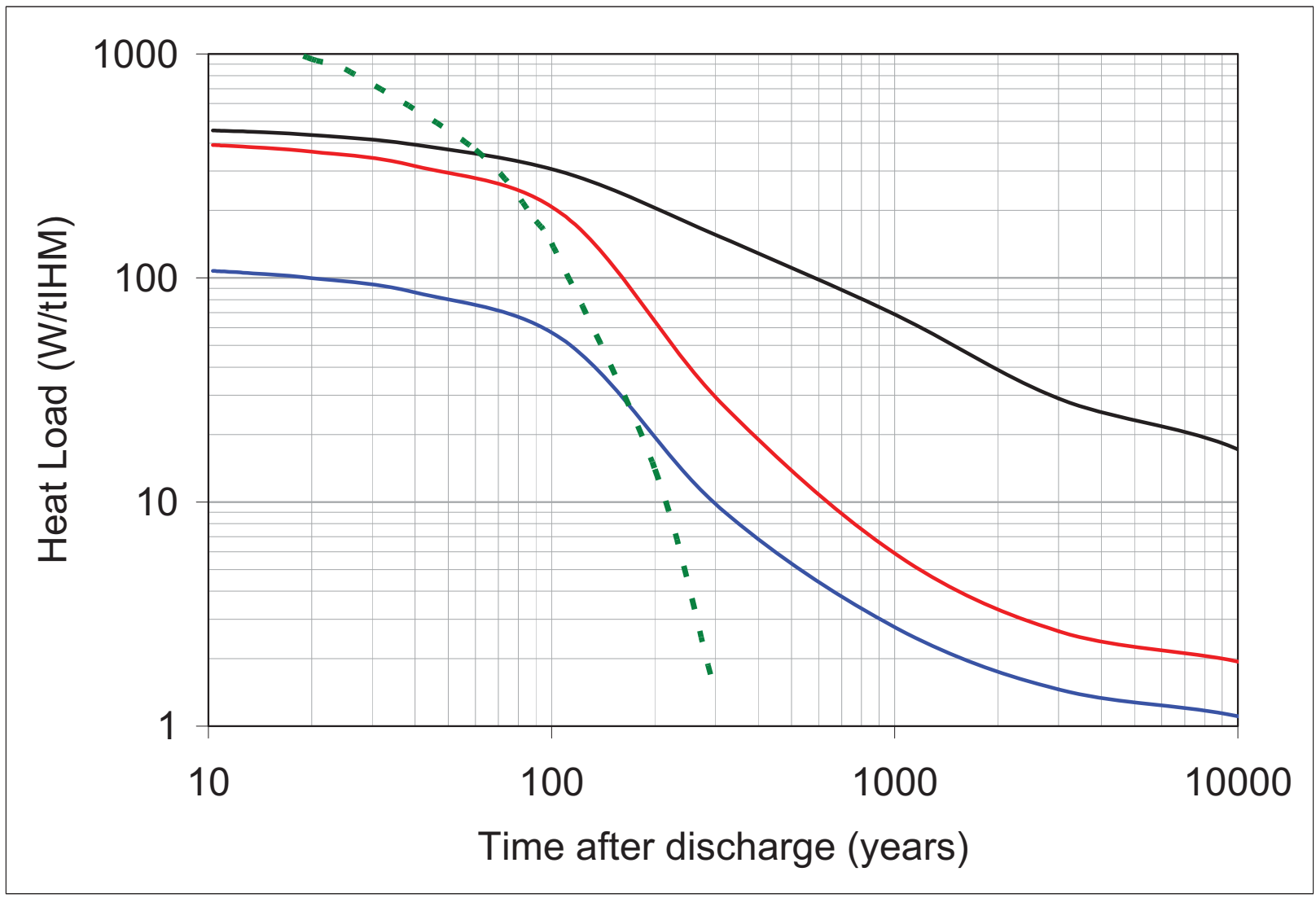

Figure D.1. Heat load (W/tIHM) related to the TRU $(\& \mathrm{~Pa})$ that needs to be disposed of as a function of the time after discharge. Reference $\mathrm{UO}_{2}$ in black, First recycling of the $(\mathrm{Th}-\mathrm{U}) \mathrm{O}_{2}$ fuel in blue and $10^{\text {th }}$ recycling of the (Th-U) $\mathrm{O}_{2}$ fuel in red. Heat load related to the $\mathrm{UO}_{2}$ Fission Products in dashed-green. Water-to-fuel volume ratio $=2$. Burnup $=45,000 \mathrm{MWd} / \mathrm{t}_{\mathrm{HM}}$. Light-water-cooled case . 


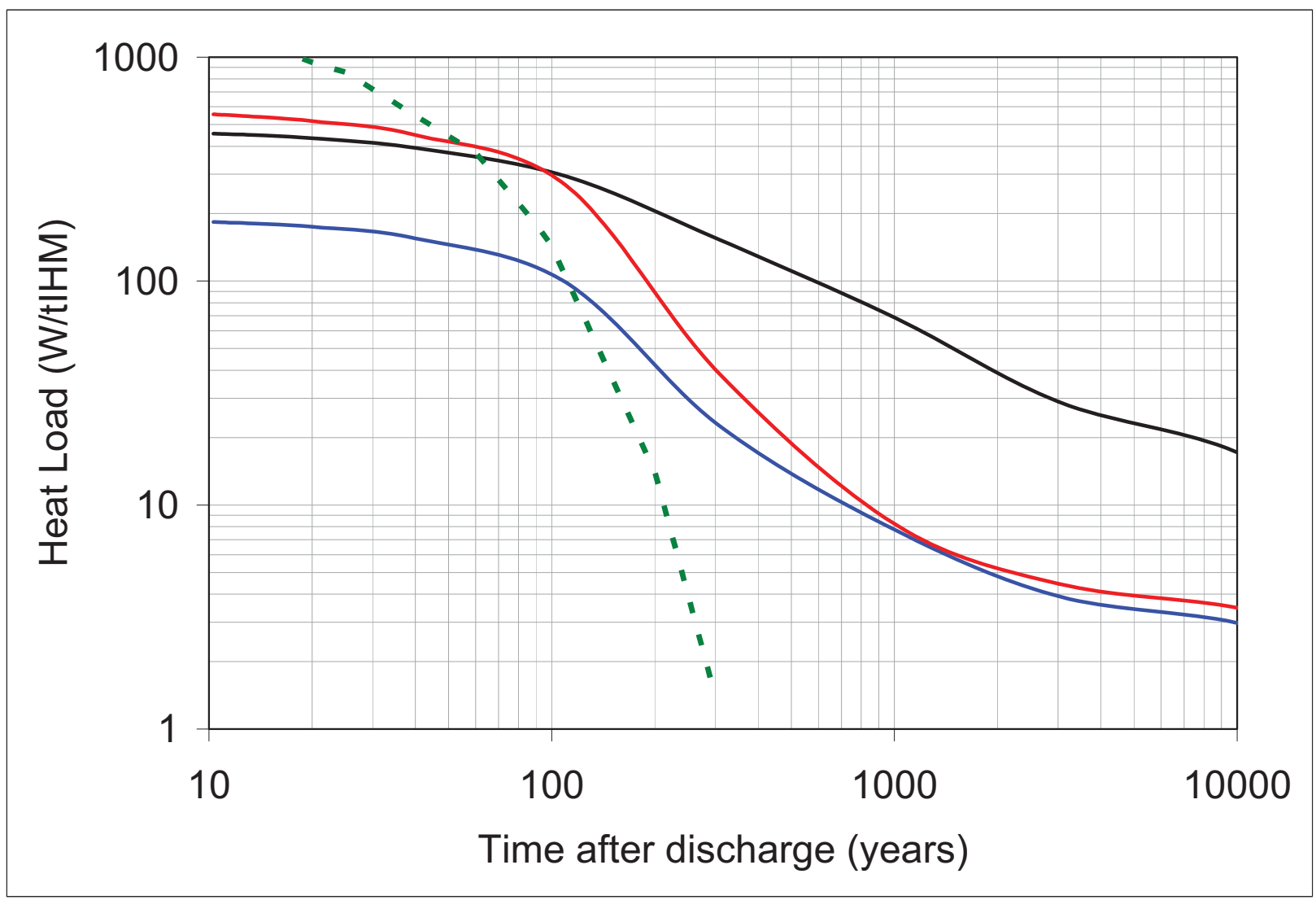

Figure D.2. Heat load (W/tIHM) related to the TRU (\& Pa) that needs to be disposed of as a function of the time after discharge. Reference $\mathrm{UO}_{2}$ in black, First recycling of the $(\mathrm{Th}-\mathrm{U}) \mathrm{O}_{2}$ fuel in blue and $10^{\text {th }}$ recycling of the (Th- $U) \mathrm{O}_{2}$ fuel in red. Heat load related to the $\mathrm{UO}_{2}$ Fission Products in dashed-green. Water-to-fuel volume ratio $=0.6$. Burnup $=45,000 \mathrm{MWd} / \mathrm{t}_{\mathrm{HM}}$. Light-water-cooled case. 


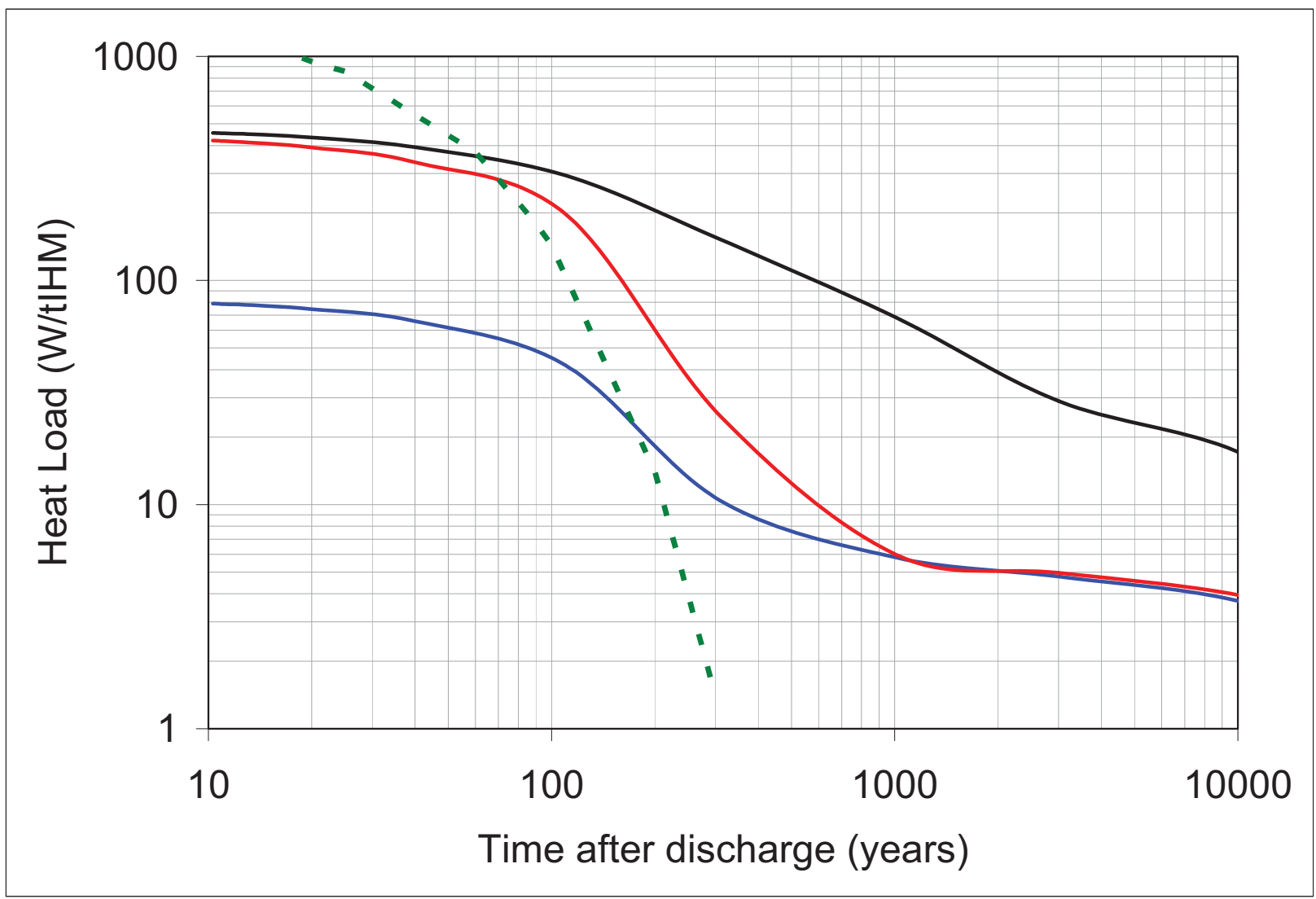

Figure D.3. Heat load (W/ttHM) related to the TRU (\& Pa) that needs to be disposed of as a function of the time after discharge. Reference $\mathrm{UO}_{2}$ in black, First recycling of the $(\mathrm{Th}-\mathrm{U}) \mathrm{O}_{2}$ fuel in blue and $10^{\text {th }}$ recycling of the $(\mathrm{Th}-\mathrm{U}) \mathrm{O}_{2}$ fuel in red. Heat load related to the $\mathrm{UO}_{2}$ Fission Products in dashed-green. Water-to-fuel volume ratio $=2$. Burnup $=45,000 \mathrm{MWd} / \mathrm{t}_{\text {HM. }}$. Heavy-water-cooled case. 


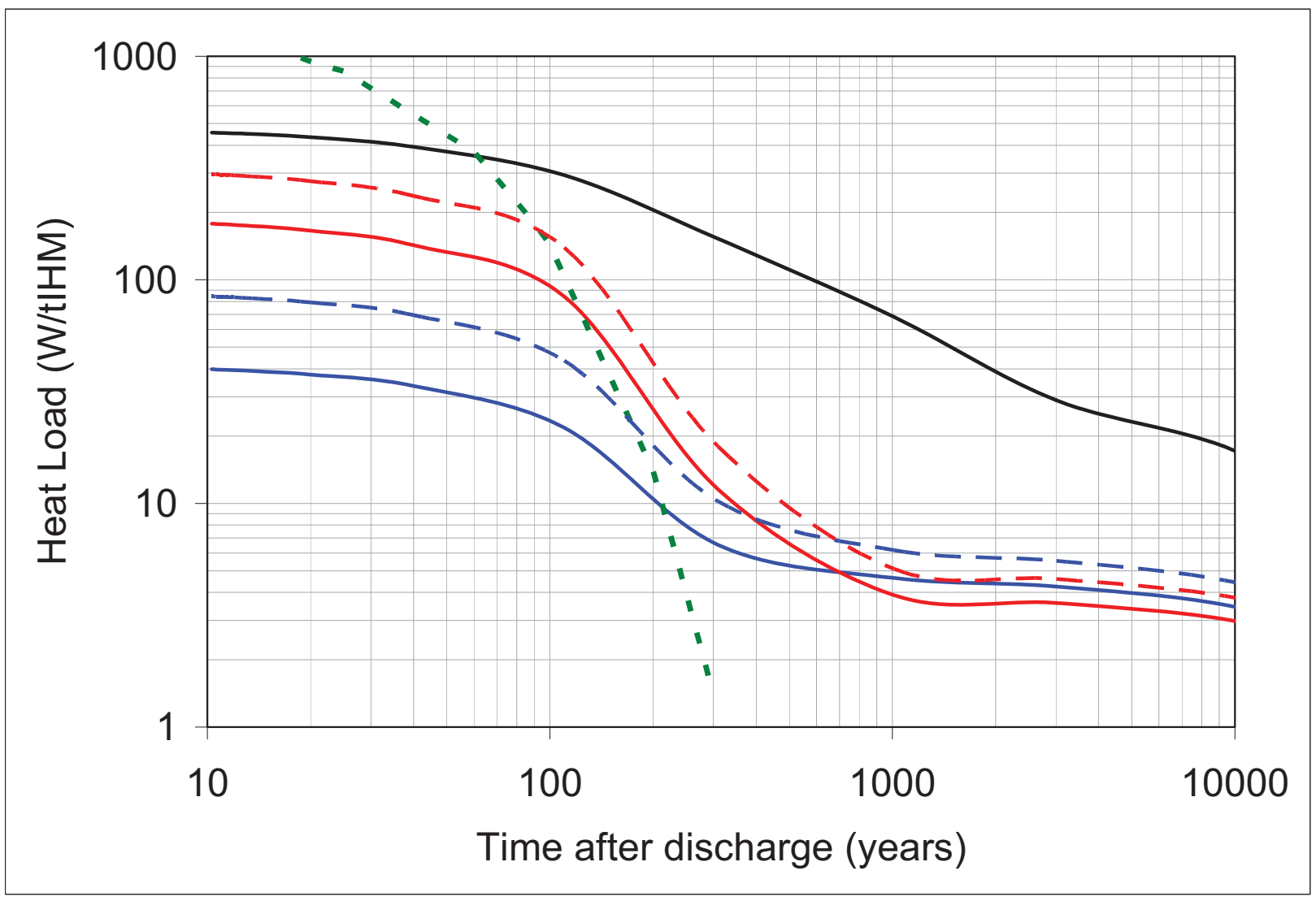

Figure D.4. Heat load (W/tIHM) related to the TRU ( \& Pa) that needs to be disposed of as a function of the time after discharge. Reference $\mathrm{UO}_{2}$ in black, First recycling of the $(\mathrm{Th}-\mathrm{U}) \mathrm{O}_{2}$ fuel in blue (solid $=$ $45,000 \mathrm{MWd} / \mathrm{t} \&$ dashed $=60,000 \mathrm{MWd} / \mathrm{t}$ ) and $10^{\text {th }}$ recycling of the $(\mathrm{Th}-\mathrm{U}) \mathrm{O}_{2}$ fuel in red (solid $=45,000$ $\mathrm{MWd} / \mathrm{t} \&$ dashed $=60,000 \mathrm{MWd} / \mathrm{t}$ ). Heat load related to the $\mathrm{UO}_{2}$ Fission Products in dashed-green. Water-to-fuel volume ratio $=0.6$. Burnup $=45,000 \& 60,000 \mathrm{MWd} / \mathrm{t}_{\mathrm{HM}}$. Heavy-water-cooled case . 


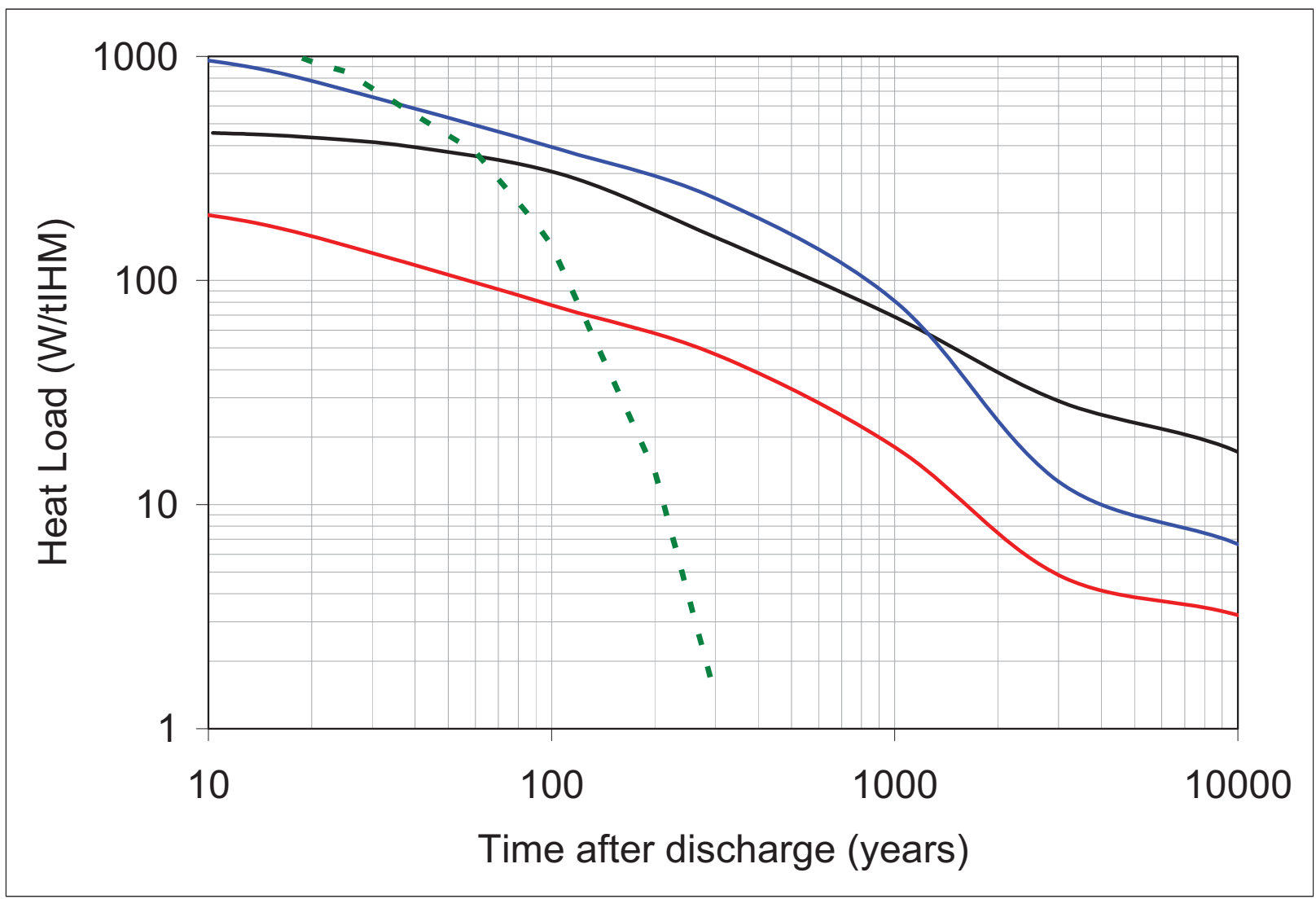

Figure D.5. Heat load (W/tIHM) related to the TRU (\& Pa) that needs to be disposed of as a function of the time after discharge. Reference $\mathrm{UO}_{2}$ in black, First recycling of the (Th-U-Pu) $\mathrm{O}_{2}$ fuel in blue and $10^{\text {th }}$ recycling of the (Th-U-Pu) $\mathrm{O}_{2}$ fuel in red. Heat load related to the $\mathrm{UO}_{2}$ Fission Products in dashed-green.

Water-to-fuel volume ratio $=0.6$. Burnup $=45,000 \mathrm{MWd} / \mathrm{t}_{\mathrm{HM}}$. Heavy-water-cooled case. 


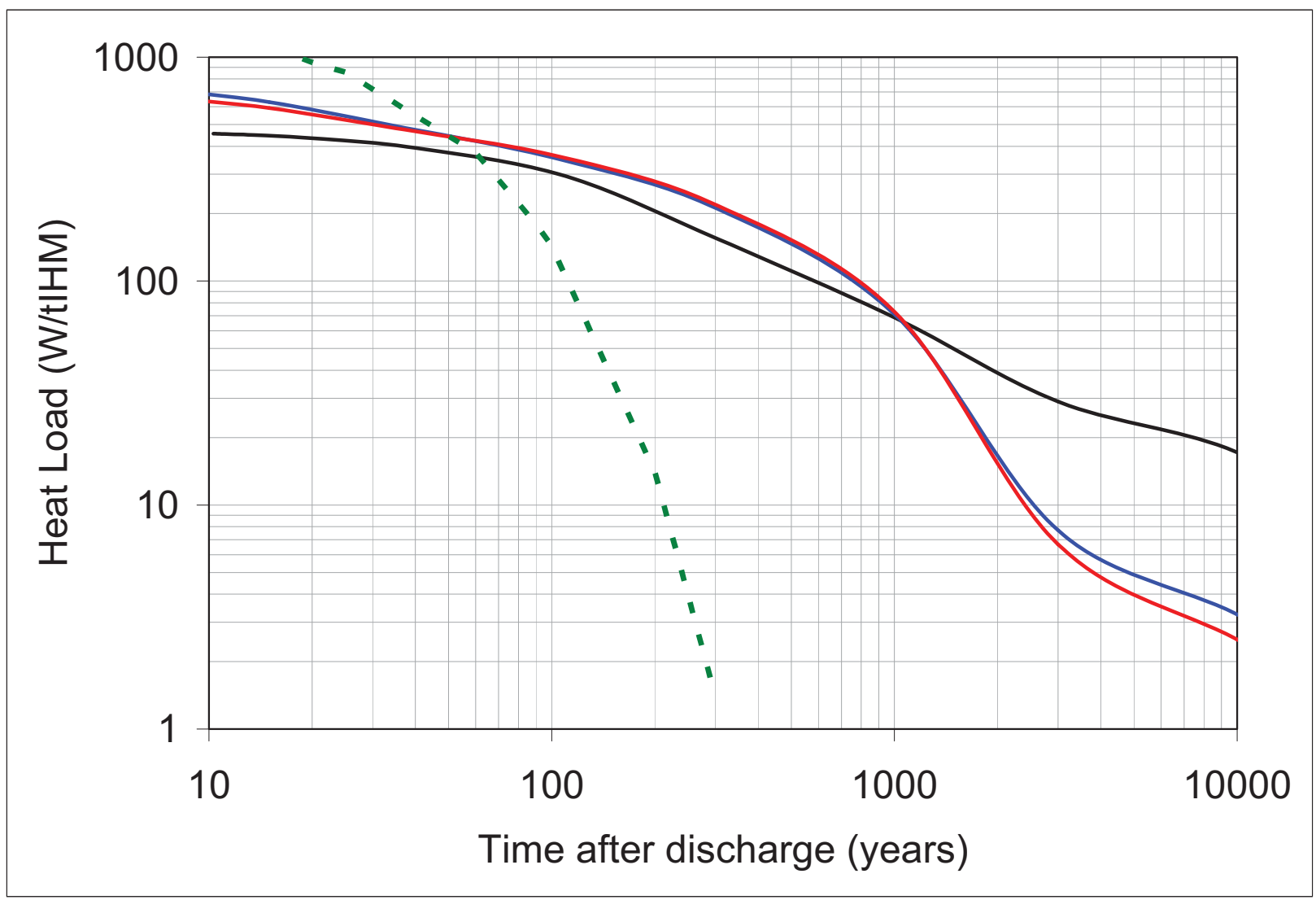

Figure D.6. Heat load (W/ttHM) related to the TRU (\& Pa) that needs to be disposed of as a function of the time after discharge. Reference $\mathrm{UO}_{2}$ in black, First recycling of the $(\mathrm{U}-\mathrm{Pu}) \mathrm{O}_{2}$ fuel in blue and $10^{\text {th }}$ recycling of the $(\mathrm{U}-\mathrm{Pu}) \mathrm{O}_{2}$ fuel in red. Heat load related to the $\mathrm{UO}_{2}$ Fission Products in dashed-green.

Water-to-fuel volume ratio $=0.6$. Burnup $=45,000 \mathrm{MWd} / \mathrm{t}_{\mathrm{HM}}$. Heavy-water-cooled case. 


\section{Appendix E}

\section{Preliminary estimation of the amount of $U$ produced in $\mathrm{ThO}_{2}$ rods in a heavy-water-cooled (Th-U) $\mathrm{O}_{2}$ lattice based one-group cross-sections and flux levels}

Given Thorium and Uranium one-group cross-sections as well as a flux level it is possible to estimate the amount of Uranium produced from neutron capture on Thorium after a given irradiation time. This is of course only a rough estimation to get an order of magnitude.

It was mentioned in Chapter 6 that the average flux level in the heavy-water-cooled lattices was about $6 \times 10^{14} \mathrm{n} \cdot \mathrm{cm}^{-2} \cdot \mathrm{s}^{-1}$. The one-group cross-sections calculated for the heavy-water-to-fuel volume ratios of 1 and 0.6 are given in the table below.

Table E.1. One-group cross-sections (barns) calculated for the heavy-water-to-fuel volume ratios of 1 and 0.6

\begin{tabular}{|c|c|c|c|c|}
\hline & \multicolumn{2}{|c|}{ D2O-to-fuel volume ratio $=0.6$} & \multicolumn{2}{c|}{ D2O-to-fuel volume ratio $=1$} \\
\hline & absorption & capture & absorption & capture \\
\hline Th232 & 0.48 & 0.47 & 0.55 & 0.53 \\
\hline U233 & 4.64 & 0.58 & 5.26 & 0.68 \\
\hline U234 & 1.67 & 1.32 & 1.96 & 1.63 \\
\hline U235 & 3.93 & 1.05 & 4.53 & 1.26 \\
\hline
\end{tabular}

If we consider that some $\mathrm{ThO}_{2}$ rods are mixed with the $(\mathrm{Th}-\mathrm{U}) \mathrm{O}_{2}$ rods as shown for example on Figure E.1 (given only for illustration purpose, not used for actual calculations), it is reasonable to consider as a first approximation that the flux level and one-group cross-sections in these $\mathrm{ThO}_{2}$ rods are the same as those calculated in the $(\mathrm{Th}-\mathrm{U}) \mathrm{O}_{2}$ lattice.

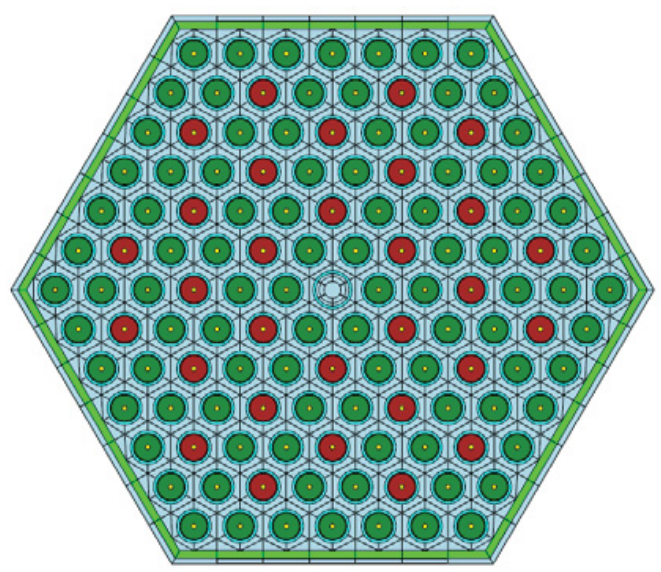

Figure E.1. Example of an hexagonal fuel assembly made up of $\mathrm{ThO}_{2}$ rods (red) and driver (Th-U) $\mathrm{O}_{2}$ rods (green) 
Furthermore, as mentioned in Chapter 2, taking into account the different specific powers given in Table 2.2, it takes about 1730 and 2140 Equivalent Full Power Days (EFPD) to reach a burnup of 45,000 MWd/t for, respectively, the water-to-fuel volume ratios of 1 and 0.6 .

Hence, given these irradiation times, flux level and one-group cross-sections, one can show that the amount of Uranium at the end of the irradiation is equal to about $40 \mathrm{~kg}$ per ton of Thorium initially loaded in both lattices, independently of the water-to-fuel volume ratio. This Uranium is made up of about $96 \%$ U233 and $4 \%$ U234. Now, if we consider that the number of $\mathrm{ThO}_{2}$ rods in the lattice amounts to $10 \%$ of that of the $(\mathrm{Th}-\mathrm{U}) \mathrm{O}_{2}$ rods, it means that, in addition to the 21.8 tons $\mathrm{HM}$ of $(\mathrm{Th}-\mathrm{U}) \mathrm{O}_{2}$ reprocessed per GWe.year (see for example Figure 6.1.3), 2.18 tons $\mathrm{HM}$ of $\mathrm{ThO}_{2}$ are reprocessed per GWe.year and about $87 \mathrm{~kg}$ of $\mathrm{U}$ is recuperated (i.e. 2.18 tons $\times 40 \mathrm{~kg} / \mathrm{ton}$ ).

For memory, without considering the $\mathrm{ThO}_{2}$ rods, the amount of $\mathrm{HEU}$ that must be added at the fabrication is about $190 \mathrm{~kg}$ and $50 \mathrm{~kg}$ per GWe.year for, respectively, the heavy-water-to-fuel volume ratios of 1 and 0.6 (see Figure 6.1.3). Thus the $87 \mathrm{~kg}$ of $\mathrm{U}$ produced per $\mathrm{GWe}$.year in the $\mathrm{ThO}_{2}$ rods could potentially make the system self-sustainable, or at least it could compensate for the inevitable losses at reprocessing.

Again, this is only a rough estimation and more detailed assembly calculations, based on geometries as shown on Figure E.1 for example, are necessary to get a better idea of the amount of Uranium bred in the $\mathrm{ThO}_{2}$ rods. 